UNIVERSIDADE DE SÃO PAULO

INSTITUTO DE GEOCIENNCIAS

\title{
APLICAÇÃO DA ANISOTROPIA DE SUSCEPTIBILIDADE MAGNÉTICA NA ANÁLISE CINEMÁTICA EM ROCHAS METAMÓRFICAS DE ALTO GRAU - COMPLEXOS JUIZ DE FORA E PARAÍBA DO SUL-DIVISA MG/RJ
}

\section{TÂNIA MARIZE DE CASTRO JACOBSOHN}

Orientador: Prof. Dr. Marcos Egydio da Silva

DISSERTAÇÃO DE MESTRADO

COMISSÃO JULGADORA

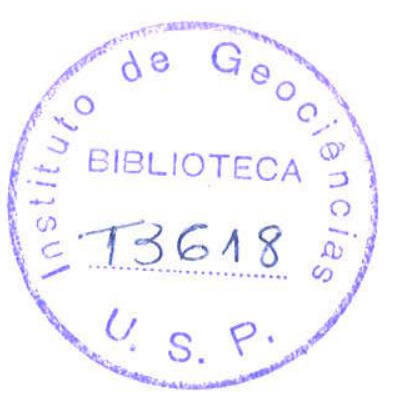

Nome

Assinatura

Presidente: Prof. Dr. Marcos Egydio da Silva

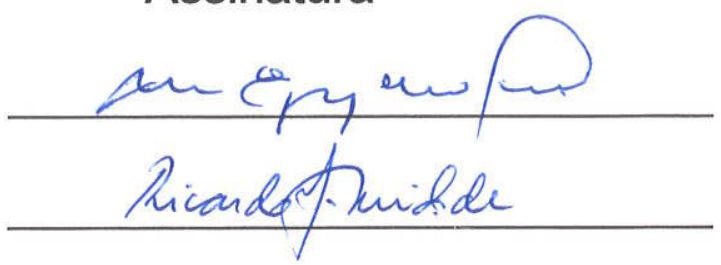

Prof. Dr. Rômulo Machado

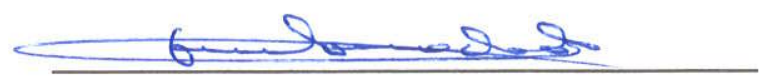

SÃO PAULO

2002 
UNIVERSIDADE DE SÃO PAULO

INSTITUTO DE GEOCIÊNCIAS

"APLICAÇÃO DA ANISOTROPIA DE SUSCEPTIBILIDADE MAGNÉTICA NA ANÁLISE CINEMÁTICA EM ROCHAS DE

ALTO GRAU METAMÓRFICO"

COMPLEXOS JUIZ DE FORA E PARAÍBA DO SUL - DIVISA MG / RJ

TANIA JACOBSOHN
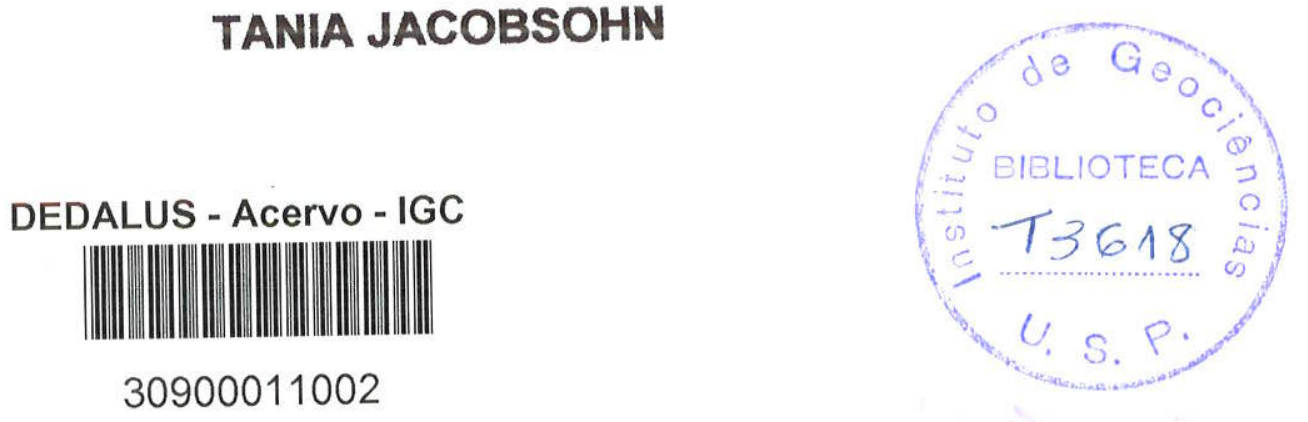

Dissertação de Mestrado

Orientador: Prof. Dr. MARCOS EGYDIO DA SILVA

Programa de Pós Graduação em Geoquímica e Geotectônica

São Paulo - Brasil

2002 


\section{Agradecimentos}

Agradeço ao Prof. Dr. Marcos Egydio da Silva pela confiança em minha capacidade de trabalho, pela revisão do texto e por sua paciência e gentileza ímpares.

Devo à CAPES o suporte financeiro de bolsa de estudos, auxílio para as análises de laboratório e para parte dos trabalhos de campo.

Agradeço a valiosa colaboração dos Profs. Drs. Ginaldo Campanha, Mauro Cesar Geraldes, Nolan Dehler, Georg Robert Sadowski, Rômulo Machado, Joel Sígolo, Oswaldo Siga Jr., Caetano Juliani, Carlos Archanjo, Darci Svizero e Gianna Garda, do Instituto de Geociências - IG/USP, que contribuiram, em campo e através de proveitosas discussões, para o esclarecimento de vários pontos deste trabalho.

Herzliche Grüße e gratidão ao Prof. Dr. Fábio Ramos Dias de Andrade, IG/USP e ao Prof. Dr. Hans Dirk Ebert, IG/UNESP, pela atenção e tempo dispensados na correção do texto e mapas e discussões sobre a geologia da área.

Devo à inspiração e competência da Profa. Dra. Maria de Fátima Bitencourt, IGUFRGS, a base e a motivação pelo estudo da geologia estrutural. Agradeço por seus ensinamentos e conselhos técnicos, auxiliando na integração dos dados e conclusões do presente trabalho.

Agradeço pelo generoso auxílio e carinho dos colegas: José Francisco Borba Martins, UNISINOS; Prof. Dr. Francisco Negri, Instituto Geológico-SP, Fernando Pelegrini Spinelli, Thatyana Benevides, Heloisa Dehler, Gilberto Kaufuss, Marcelus Araújo, Prof. Dr. Ossama Harara, Jérôme Bascou, Liliane Janikian, Prof. Dr. Renato Paes de Almeida, USP; Prof. Dr. Adelir Strieder, UFRGS; Prof. Dr. Marcos Tadeu Suita, UFOP; Profs. Drs. Henrique Fenstenseifer, Marco Antonio Hansen, Tania Lindner e Ubiratan Feruccio Faccini, UNISINOS.

Ao corpo técnico da USP, especialmente Isaac Sayeg (MEV), Verônica dos Santos (Lab. ATD), Flávio Carvalho (Lab. DRX), Tadeu Caggiano (Apoio Pós Grad.), Cláudio Hopp, Paulo Morgato e Luiz Nogueira (Laminação), Paulo Molinaro (Lab. LTA), Angélica Morente (Lab. Ótica), Erica e Brenda (Biblioteca), Magali Rizzo e Ana Paula Carbonal (Sec. Pós Grad.), Jaime (Sec. Fotografia) e Gráfica do IG, sou grata pela colaboraçäo com eficiência e gentileza.

Aos amigos Cristiane Aily, lede Zolinger, Fernando Pelegrini, Valéria Guimarães, Profa. Ivone Peres, Emerson e Tatiana Jacobsohn, sou grata pelo carinho e presença constantes. 


\section{Resumo}

A anisotropia de susceptibilidade magnética (ASM) foi utilizada como ferramenta auxiliar para o estudo do comportamento cinemático de de rochas metamórficas de alto grau, paleoproterozóicas, retrabalhadas durante o Ciclo Brasiliano, cuja evolução inclui metamorfismo progressivo, fácies anfibolito alto e fácies granulito, migmatização, milonitizaçäo e metamorfismo retrógrado, numa área localizada na Faixa Ribeira, divisa Minas Gerais - Rio de Janeiro, região sudeste do Brasil.

A contribuição de minerais ferromagnéticos e paramagnéticos, como magnetita, pirrotita, hematita alto titânio, ilmenita, biotita, piroxênio e anfibólio, responde pela fábrica magnética das rochas estudadas.

Os elipsóides de ASM, predominantemente oblatos, mostraram eixos definidos e coordenadas geográficas concordantes com as atitudes das estruturas planares e lineares observadas em campo, agrupamento estatístico consistente e, fábrica magnética normal, possibilitando visualizar o comportamento cinemático da área, através da aplicação da técnica da ASM.

A associação dos estudos petrogránicos, dados de campo e medidas da ASM indicaram que a área foi afetada por colisão frontal, de direçăo aproximada leste oeste, que produziu transporte de massa para oeste, ao longo de falhamentos de empurrão, com mergulho suave para SE, num domínio de predominância da tectônica tangencial. Uma componente oblíqua associada produziu deslocamentos ao longo de um plano de alto ângulo, de direção NE, com sentido de NE para SW, em domínio da tectônica direcional, no limite oriental da área.

O quadro cinemático, considerando as principais direções de movímento e tensão verificadas na área, sugere um modelo evolutivo de convergência frontal do Cráton do Congo com o Cráton do São Francisco, no Neoproterozóico, sob regime transpressional. Falhamentos de empurrão, que promoveram o deslizamento de rochas de profundidade, sobre rampas oblíquas de baixo ângulo, para oeste, em direção ao Cráton do São Francisco, foram sucedidos por deslizamento direcional de massa, de NE para SW, ao longo de uma zona de cisalhamento dextrogira, de atitude média N45E/60SE. A fase tangencial, de cavalgamentos obliquos, precedeu a fase transcorrente, dentro de um mesmo evento transpressivo, onde ocorreram soerguimento, rotação e inversão dos blocos de rocha que hoje afloram na região. 


\begin{abstract}
Anisotropy of magnetic susceptibility (AMS) was applied to study the kinematic behavior of high grade metamorphic rocks, with paleoproterozoic age, reworked during the Brasiliano Cicle, which geological history includes progressive metamorphism in high amphibolite and granulite facies, migmatization, mylonitization and retrogressive metamorphism, located in Ribeira Folded Belt, southeast of Brazil.

The magnetic fabric is carried by ferromagnetic and paramagnetic minerals, mainly magnetite, high-Ti hematite, pyrrothite, piroxene, amphiboles and biotite.

The AMS elipsoids, oblates in mostly part of the area, have well defined axes and, the geographic coordinates of AMS axes were in good agreement with planar and linear structures attitude, observed in the field studies. The AMS eigenvectors, K1, K2 and K3, shown a straight groupment, all over the area, as well the AMS data, correlated with the field data, indicated a normal magnetic fabric. These data enabled to find the kinematic scenario and to recognize the effects of coaxial and non-coaxial strain, in the area.

The association of petrographic studies, conventional structural methods and AMS measurements, allowed to conclude that the area has undergone frontal collision, with mass displacements towards the west, east - west sense, through thrust faults, gentle dipping SE, in tangencial domain. One oblique associated component developed strikeslip and down dip faults, NE strike, NE to SW sense, in transcurrent domain, eastwards.

The kinematic scenario, regarding the main stress and movement strikes, suggests a tectonic evolution where the Congo and San Francisco had undergone frontal convergency, during the Brasiliano Cicle, under transpressional conditions. Thrust faults, along low - angle lateral oblique ramps, caused the mass transport towards the west, followed by strike - slip displacements along NE-SW high - dip shear zone, with dextral sense, attitude N45E/60SE. The oblique thrusts were previous to the transcurrent movements, both in the same transpressional domain, where the rocks wich outcrop in the area were uplift, rotated, flattened and sheared.
\end{abstract}


Indice

1. Introdução e objetivos. 01

1.1. Localização geográficà “ 01

1.2. Contexto geológico regional " . 02

1.3. Contexto geológico local

2. Metodologia de trabalho 11

2.1. Trabaho de campo, amostragem e petrografia 11

2.2. Análise estrutural e cinemática.

2.3. Anisotropia de susceptibilidade magnética-ASM 17

2.3.1. Amostragem e equipamentos de análise " 18

2.3.2. Susceptibilidade magnética e ASM . . 22

2.3.2.1. Caracterização do elipsóide de ASM “. . 23

2.3.2.2. Anisotropia magneto-cristalina e anisotropia de forma

2.3.2.3. Parâmetros de anisotropia magnética 25

2.3.3. Magnetismo e caracterização da mineralogia magnética 27

2.3.3.1. Minerais magnéticos $\quad 30$

2.3.3.2. Caracterização dos minerais magnéticos identificados 30

2.3.3.3. Fábrica magnética. 35

2.3.4. ASM e análise estrutural de rochas metamórficas 36

3. Petrografia e metamorfismo $\quad 40$

3.1. Complexo Juiz de Fora 42

3.2. Complexo Paraiba do Sul 51

3.3. Gnaisse Eugenópolis $\quad 55$

3.4. Suite Intrusiva Espírito Santo 57

3.5. Interpretação e discussão dos dados $\quad 59$

4. Análise estrutural e cinemática 68

4.1. Comparação da petrofábrica com a fábrica magnética 71

4.2. Interpretação e discussão dos dados $\quad 80$

5. Medidas de anisotropia de susceptibilidade magnética 85

5.1. Interpretação e discussão dos dados 96

6. Conclusões 105

Referências 106

Anexos

A.1. Síntese bibliográfica regional A.01.

A.2. Difratometria de raios $X \quad$ A.37.

$\begin{array}{ll}\text { A.3. Mapa geológico A.53. } & \text { A.37. }\end{array}$ 


\section{Índice de Figuras e Tabelas}

Fig. 1.1. Localização geográfica da área, vias de acesso e articulação das folhas. (detalhe do mapa de Fonseca et al. (1979) - escala original 1:1:000:000).

Fig.1.2. Mapa corn os domínios tectono-estruturais do sudeste do Brasil; (Machado \& Demange, 1994). A área do presente trabalho está localizada predominantemente no Domínio Juiz de Fora, com pequena porção, no extremo sudeste, localizada no Domínio Paraiba do Sul:

Fig. 2.1. Amostragem em campo para estudos de ASM. a) perfuratriz à gasolina; b) sonda de alumínio com coroa diamantada, c) reservatório de água com óleo mineral para lubrificação do furo; d) nivelador da bússola; e) suporte para a bússola; f) cilindro de alumínio para apoio da bússola e orientação do testemunho; g) canaleta para marcrações e orientação do testemunho; $h$ ) testemunho retirado do afloramento; i) furo.

Fig. 2.2. Aparetho Kappabridge KLY - 3S a) unidade de medidas; b) unidade de controle; c) computador; d) amostra orientada para análise.

Fig. 2.3. Posicionamento das amostras para análise no $\mathrm{KLY}-3 \mathrm{~S}$ : a) Desenho esquemático frontal da parte superior do $\mathrm{KLY}$ - $3 S$ que rotaciona as amostras, evidenciando o porta-amostra; sistema de correias e marcas de alinhamento. N.B... a seta que orienta a amostra deve estar perfeitamente alinhada com a marca existente no portaamostra, caso contrário serão gerados dados bipolares, sem significado geológico. b) Amostra cilindrica, marcada segundo a orientação do furo e conforme os eixos da própria amostra $\left(x_{1}, x_{2}, x_{3}\right)$ é colocada e fixada manualmente no porta-amostras do susceptibilímetro (vista frontal, simplificada), primeiro alinhando $x_{1}$ com a marca existente no porta-amostras, quando obtido um conjunto de medidas; depois alinhando $x_{2} e$ finalmente $x_{3}$; durante cada série de medidas; a amostra é rotacionada em 15 posiçóes (desenhos de 1. a 15), que fornecem as medidas de susceptibilidade do material.

Fig. 2.4. Elipsóide de susceptibilidade magnética: $\mathrm{Kl}=$ eixo cujo valor escalar representa a. susceptibilidade máxima (Kmax) e cuja atiude geográfica representa a lineação magnética; $K 2$ = eixo cujo valor escalar representa a susceptibilidade intermediária (Kint); $\mathrm{K} 3$ = eixo cujo valor escalar representa a susceptibilidade mínima ( $\mathrm{Kmin}$ ) e cuja atitude geográfica representa o pólo da foliação magnética.

Fig. 2,5. Anisotropia da fábrica magnética em relação à petrofábrica dos principais minerais magnéticos de rochas de composição granítica (extraída de Archanjo, 1993). K1, $\mathrm{K} 2$ e $\mathrm{K} 3$ são os eixos de susceptibilidade magnética dos minerais, $\mathrm{K} 1 \geq \mathrm{K} 2 \geq \mathrm{K} 3 . \quad 25$

Fig. 2.6. Comportamentos magnéticos conforme a relação M/H. A susceptibilidade magnética $(K)$ varia em função dos diferentes comportamentos magnéticos: $A$ declividade das retas define o valor de $K$ para os minerais paramagnéticos; antiferromagnéticos e: diamagnéticos. K: razão entre M (magnetização) e H (campo magnético induzido). Para os minerais ferromagnéticos: Ms: magnetização de saturação, o ferromagnetismo mostra susceptibilidade fortemente positiva em campo fraco mas que se anula em campo forte devido à Ms; Mr: magnetização remanescente, os minerais ferromagnéticos apresentam uma imantação residual ou remanescente, mesmo sob campo indutor nulo. (extraída de Dunlop et.al.; 1997).

Fig. 2.7: Diagrama de fases do grupo dos espinélios. (modificado de Dunlop et al: 1997).

Fig. 2.8. Parte da cela unitária da magnetita. (modificada de Dunlop et al,; 1997). 
Fig. 2.9. Estrutura cristálina e magnética da pirrotita. Estrutura magnética e distribuição das vacâncias (circulos abertos) e ions de $\mathrm{Fe}^{+2}$ (esferas pretas e hachuradas, de momentos magnéticos opostos) na pirrotita. A estrutura básica é hexagonal, com subretículos magnéticos correspondendo a planos basais alternados. As vacâncias (vazios) são arranjadas em super-retículos monoclínicos (limhas tracejadas) e estão arranjadas preferencialmente em um dos dois sub-retículos magnéticos, originando o momento ferrimagnético intenso da pirrotita. (extraído de Stacey \& Banerjee, 1974, apud Dunlop, 1997):

Fig. 2:10. Variação dos parâmetros de anisotropia $L$ e F com o teor de magnetita (gráfico modificado de Borradaile, 1987, apud Archanjo, 1993): A anisotropia intrínseca da magnetita usada neste modelo é de $L=1,07$ e $F=1,04$. Neste gráfico, K1, K2 e K3 são as susceptibilidades principais da rocha modelo e cada linha no gráfico corresponde à variação na susceptibilidade de uma rocha em que $40 \%$ de sua susceptibilidade é carregada pelo mineral nomeado na linha. Os círculos no extremo distal de cada linha indicam a anisotropia na presença de $1 \times 10$ E-6\% de magnetita. Os círculos ao longo das linhas indicam os aumentos sucessivos no teor de magnetita (segundo as setas). A maior proporção de magnetita (1\%) plota muito próxima ao ponto onde plota a anisotropia intrínseca da magnetita pura usada neste modelamento. As mudanças na forma do elipsóide de ASM são substanciais, de oblato a prolato nos casos extremos, de acordo com a variação no teor de magnetita:

Fig. 3:1. Diagrama $P \times T$ com as fácies metamónficas e diagramas $A C F$ das assembléias mineralógicas. Em azul, os diagramas da fácies granulito e em vermelho, os diagramas da fácies anfibolito, (extraído de Philpotts, 1989).

Fig. 3.2: Diagrama P XT mostrando as principais fácies metamórficas e o ponto triplo da alumina, com os campos de estabilidade da cianita, andaluzita e sillimanita, no metamorfismo regional de rochas máficas (Holdaway, 1971, apud Spear, 1993). 60

Tab. 3.1. Características petrográficas das litologias da área.

62

Fig. 4:1. Mapa de pontos com a localização dos pontos estudados na área.

Fig: 4.2. Mapa simplificado com as estruturas planares/lineares obtidas em campo. 70

Fig. 4.3. Mapa simplificado das coordenadas geográficas de K1(lineações magnéticas) e K3 (pólos dos planos de foliações magnéticas) médias dos afloramentos analisados: 70

Fig. 4.4. Mapa esquemático com a divisão da área em setores

Fig. 4.5. Diagramas de contorno das atitudes de foliação e lineação do setor norte

72

Fig. 4:6. Diagramas de contorno das atitudes de foliação e lineação do setor central 72

Fig. 4:7. Diagramas de contorno das atitudes de foliação e lineação do setor sul 72

Fig. 4.8. Estereograma com as atitudes de foliação e lineação obtidas em campo 76

Fig. 4:9. Diagramas de contorno com as coordenadas geográficas dos autovetores de $A S M, K 1, K 2$ e K3, representativas da média de cada afloramento 77

Fig. 4.10. Diagrama de contorno das atitudes magnéticas no domínio tangencial . 78

Fig. 4.11. Diagrama de contorno das atitudes magnéticas no domínio direcional $\quad 79$

Fig. 4:12: Mapa esquemático das estruturas presentes na área estudada. 
Fig:4: 13. Bloco diagrama da área. (adaptado e modificado de Brenner et al, 1980 e Ebert \& Hasui; 1998). A figura exemplifica os movimentos ocomidos nos blocos presentes na área e a posição das foliações encontradas.

Fig. 4: 14. Desento esquemático do quadro tectônico que abrange a área desta dissertação, em mapa modificado de Ebert \& Hasui, 1998.

Tab. 5.1. Dados de ASM da área.

Fig. 5.2. Gráfico de grau de anisotropia (P) das amostras analisadas neste trabalho. Na ordenada temos $P$ (razão entre $K 1$ e K3) e na abcissa temos a amostra correspondente. P reflete o grau de deformação do elipsóide de ASM.

Fig. 5.3. Gráfico de P nas litologias do Complexo Juiz de Fora.

Fig. 5.4. Gráfico de P nas litologias do Complexo Paraíba do Sul:

Fig. 5.5. Relação $T \times P^{\prime}$ para o conjunto das amostras da área estudada.

Fig. 5.6. Plotagem do parâmetro $\mathrm{T}$ (de forma) das amostras da área estudada.

Fig. 5.7. Gráficos dos parâmetros $T \times$ P' referentes a todos os afloramentos da área. 89

Fig. 5.8. Plotagem de $L(K 1 / K 2) \times F(K 2 / K 3)$ das amostras (médias por afloramento) da área estudada. Similar à plotagem de Flinn. Correlaciona anisotropia planar com anisotropia linear.

Fig. 5.9. Gráifico de porcentagem de anisotropia (H×100) para as amostras da área. 91

Fig. 5. 10. Gráfico de (Hx100) das amostras do Complexo Paraiba do Sul . $\quad 92$

Fig. 5.11. Gráfico de (H×100) para as amostras do Complexo Juiz de Fora.

Fig. 5.12: Estereogramas representativos de cada afloramento analisado pela ASM: detalhes no texto.

\section{Figuras dos Anexos}

\section{Anexo 1}

Fig. A.1: Principais unidades geotectônicas do Brasil

Fig. A.2. Detalhe do mapa geológico de Machado Filho et al, 1983

Fig. A.3. Mapa com o contexto estrutural e cinemático do sudeste do Brasil

Fig. A.4: Províncias geológicas do Brasil; do sudeste e Faixa Ribeira

Fig. A.5. Domínios tectônicos do sudeste do Brasil

\section{Anexo 2}

Fig: A.6. Difratograma da amostra

KJ378

Fig. A.7. Difratograma da amostra

KJ3782B

Fig. A.8. Difratograma da amostra

KJ379

Fig. A.9. Difratograma da amostra

Fig. A.10: Difratograma da amostra 
Fig. A.11. Difratograma da amostra $K J 3841 E$

Fig. A.12. Difratograma da amostra KJ3852 43

Fig. A.13. Difratograma da amostra KJ3853DX 44

Fig. A.14. Difratograma da amostra KJ3872D 45

Fig. A.15. Difratograma da amostra $\mathrm{KJ} 388$

$\begin{array}{lll}\text { Fig. A. 16. Difratograma da amostra } & \mathrm{KJ} 3892 \mathrm{C} & 47\end{array}$

Fig. A.17. Difratograma da amostra $\mathrm{KJ} 3902 \quad 48$

Fig. A.18. Difratograma da amostra $K J 418$

Fig: A.19. Difratograma da amostra $K J 425$

Fig. A.20. Difratograma da amostra KJ431 51

Fig. A.21. Difratograma da amostra KJ442 52

\section{Índice de Fotografias}

Prancha 1) Fotos de afloramento

fot.1. Afloramento de biotita-granada gnaisse granulítico (jfkz). Complexo Juiz de Fora. Ponto KJ383, estrada Laranjal - Muriaé.

fot.2. Afloramento de biotita-granada gnaisse granulítico (jfkz). Complexo Juiz de Fora. Ponto KJ383, estrada Laranjal - Muriaé. detalhe.

Prancha 2) Fotos de afloramento

fot.3. Afloramento de granadaw hornblenda- biotita gnaisse (jfkz), com enclave de granulito. Complexo Juiz de Fora. Ponto KJ 380, estrada Miracema -Laranjal. 43

fot.4. Afloramento de biotita-granada gnaisse granulítico (jfkz), Complexo Juiz de Fora. Ponto KJ378, estrada Miracema - Pádua.

Prancha 3) Fotografias de amostras

fot.5. Amostra de granulito, (jfgg), ponto KJ414. 44

fot.6. Amostra de charnockito, (ifgg), ponto $\mathrm{KJ} 383$.

fot:7. Amostra de granada gnaise granulítico migmatizado (jfkz), ponto KJ385. 44

fot.8. Amostra de biotita-hornblenda gnaisse granulitico (ffkg), ponto KJ384. 44

fot.9. Amostra de biotita-hormblenda gnaise milonitico (pskg), ponto KJ391.

fot 10. Amostra de biotita-granada gnaisse (pskz), ponto KJ378 44

Prancha 4) Fotomicrografias

fot. 11. afloramento KJ442; lâmina KJ442t1 - granulito; textura granoblástica, com forte recristalização e formação de sub-grãos. Detalhe na foto da direita. $\quad 46$

fot: 12. afloramento KJ442, lâmina KJ442 22 - granulito; textura granoblástica, com forte recristalização e formação de sub-grãos. 
fot. 13. aftoramento KJ452, lâmina KJ452a - gramulito; plagioclásio levemente deformado associado a biotita primária, euédrica, inclusa no cristal e biotita secundária, cristalizada na borda do plagioclásio.

fot: 14. afloramento $\mathrm{KJ} 387$; lâmina $\mathrm{KJ} 387 \mathrm{ba}$ - granada granulito; plagioctásio com saussuritização no centro do cristal, devido a um maior teor de cálcio no centro ou sobrecrescimento de uma fase menos cálcica com alteração do núcteo do cristal.

fot: 15 . afloramento $\mathrm{KJ} 386$; lâmina $\mathrm{KJ} 3862$ - migmatito de gnaisse granulítico; evidência de metamorfismo retrógrado, com hornblenda substituindo as bordas do cristal de piroxênio; formando uma corona.

fot 16 . aftoramento $\mathrm{KJ} 387$, lâmina $\mathrm{KJ} 387 \mathrm{e}$ - granada granulito; biotita associada a duas gerações de mineral opaco, a primeira como inclusão e a segunda como cristais bem desenvolvidos na borda e entrando nas clivagens da biotita.

fot. 17. afloramento $\mathrm{KJ} 378$, lâmina $\mathrm{KJ} 378 \mathrm{f}$ - biotita-granada gnaisse granulítico; plagioclásio com inclusão de biotita e minerais opacos subédricos, primários e associada à biotita e minerais opacos secundários, nas bordas do cristal.

fot: 18 . aftoramento $\mathrm{KJ} 387$, lâmina $\mathrm{KJ} 387 \mathrm{~b}$ - granada granulito; monazita com halo pleocróico, em contato com biotita com óxidos em suas fraturas, minerais opacos subédricos nas bordas, siltimanita e granada.

\section{Prancha 5) Fotomicrografias}

fot. 19. afforamento $\mathrm{KJ} 386$, lâmina $\mathrm{KJ} 386 \mathrm{~b}$ - granulito; biotita com inclusão de magnetita, com magnetita secundánia nas bordas dos cristais de biotita. cristal de piroxênio parcialmente substituido por anfibólio na borda. Cristais de biotita e hornblenda oxidados

fot:20. afloramento $\mathrm{KJ} 386$, seção polida $\mathrm{KJ} 386 \mathrm{~m}$ - granulito; magnetita, cinza azulado; martita (magnetita e hematita, rosado claro, centro preservado), 10x

fot.21. afforamento KJ457, seção polida KJ4573 - biotita-granada gnaisse granulítico; magnetita e hematita intercrescidos (cinza azulado canto inferior direito do agregado); ilmenita (cinza escuro; abaixo da hematita); pirrotita (rosa amarelado no centro do agregado), calcopirita (amarelo no canto inferior esquerdo do agregado), bornita (azulado no centro, com pirrotita), $10 x$

fot.22. afloramento $\mathrm{KJ} 457$, seção polida KJ457b - biotita- granada gnaisse granulítico; pirrotita (amarelo claríssimo no lado direito do agregado); calcopirita (amarelo vivo-claro no lado direito do agregado); pirita (amarelo vivo-escuro, lado direito do agregado); ilmenita (cinza escuro; menor); $10 \mathrm{x}$

fot:23. afforamento $\mathrm{KJ} 429$, lâmina $\mathrm{KJ} 429 \mathrm{~b}$ - biotita- hormblenda gnaisse granulítico; minerais máficos em equitíbrio; biotita, hornblenda e minerais opacos acompantham a foliação principal da rocha. Cristal de piroxênio com anfibóliơ nas fraturas e opacos nas bordas

fot.24. afloramento $\mathrm{KJ} 448$, seção polida $\mathrm{KJ} 4483$ - biotita- hormblenda gnaisse granulítico; magnetita (cinza azulado no canto inferior esquerdo da foto e canto superior: direito em cristal menor); itmenita (azul-avermelhado) intercrescido com magnetita, martita (magnetita + hematita) (amarelo +rosa claro); bordas de reação da ilmenita e hematita reagindo com silicato, canto superior esquerdo, 20x

fot.25. afloramento KJ454, seção polida KJ454l - biotita- hornblenda gnaisse granulitico; cristal de ilmenita (cinza rosado-azulado-claro) intercrescida com magnetita (cinza azulado claro no lado direito), 10x 
fot.26. aftoramento $\mathrm{KJ4} 19$, seção polida $\mathrm{KJ} 419$ - hornblenda- biotita gnaisse granulítico; magnetita (cinza), exsoluções de hematita (rosado), 10x

\section{Prancha 6) Fotomicrografias}

fot:27. afloramento $K J 451$, seção polida $K J 451 \mathrm{pg}$ - biotita- hornblenda gnaisse granulítico; pirita (amarelo pálido com tintas rosa-claras), calcopirita (amarelo canário, cristal menor); pirrotita (borda esquerda rosa na pirita), 10x

fot:28. afforamento $\mathrm{KJ} 451$, seção polida $\mathrm{KJ} 451 \mathrm{p}$ - biotita- hornblenda gnaisse granulítico; pirita (cristal amarelo com riscos do polimento), calcopirita (amarelo canário, na pirita, centro-superior); pirrotita (rosado claro, na pirita; centro-superior); $10 \mathrm{x}$

fot:29: afloramento $\mathrm{KJ} 448$, seção polida $\mathrm{KJ} 448$ - biotita hormblenda gnaisse granulítico; magnetita e hematita intercrescidos (mistura de lamelas rosada e azulada parte inferior do grão); pirita (amarelo forte), ilmenita e magnetita intercrescidos (cinza escuro e cinza claro em pequeno cristal no centro do agregado), pirrotita (amarelo com tintas rosa; centro superior do agregado), óxido de alteração nas bordas do agregado, bornita (azul em pequenos cristais na borda superior direita da pirita), crescimento de magnetita nas fraturas do silicato (tamelas cinza azuladas); 10x

fot: 30 . afloramento KJ381, lâmina KJ381m - biotita-granada gnaisse granulítico; simplectitos de quartzo nos contatos com plagioclásio e feldspato potássico (mirmequita); fitas de quartzo recristalizado ao redor do palgioclásio, biotita de primeira e segunda geração

fot:31: afloramento KJ382; lâmina KJ382bo - granada- homblenda- biotita gnaisse granulítico; agregado de biotita associada com minerais opacos com inclusões de apatita. Os minerais opacos ocorrem em cristais subédricos maiores nas bordas da biotita ou como cristais diminutos em suas fraturas:

fot:32. afloramento $\mathrm{KJ} 378$; lâmina $\mathrm{KJ} 378 \mathrm{C}$ - granada- biotita gnaisse granulítico; cristal de granada, possivelmente sincinemático (presença de fraturamento intenso) com cristais de plagioclásio, biotita e minerais opacos nas fraturas

fot:33: aftoramento KJ446, lâmina KJ446b2 - biotita- granada gnaisse granulítico; formação de biotita a partir de granada, evidenciando reequilíbrio na fácies anfibolito 50

fot: 34. afforamentơ $\mathrm{KJ} 424$; lâmina $\mathrm{KJ} 4243 \mathrm{C}$ - biotita - granada gnaisse granulítico; retrometamorfismo com evidências de reequilíbrio na fácies anfibolito; cristal de granada sendo substituido por biotita e opacos; presença de 2 gerações de biotita e de minerais opacos formados com a biotita secundária

\section{Prancha 7) Fotos de aftoramento}

fot:35. Afloramento de biotita-hornblenda granada gnaisse (pskg), Complexo Paraiba do Sul. Ponto KJ384, estrada Muriaé - Comendador Venâncio.

fot:36. Aftoramento de granito porfirítico (ges); Suíte Intrusiva Espírito Santo, em contato com hornblenda - biotita gnaisse granulítico (jfgg), cortado por dique granítico paralelo à zona de cisathamento. Ponto KJ415, estrada Miracema - Lage do Nuriaé. 52

\section{Prancha 8) Fotomicrografias}

fot:37: afforamento $\mathrm{KJ} 427$, seção polida $\mathrm{KJ} 427$ - biotita-granada gnaisse granulítico; magnetita (cristal triangular cinza azulado incluso na martita), martita em cristais maiores, em lamelas de exsolução de hematita e magnetita , $20 \mathrm{x}$ 
fot.38. afloramento KJ427, seção polida KJ427b - biotitangranada gnaisse; magnetita em cristal corroído nas bordas, reagindo com o silicato, mostrando apenas o centro preservado, $20 \mathrm{x}$

fot. 39. afloramento KJ423l, lâmina KJ4231 - biotita - hornblenda gnaisse; microclínio com inclusão de biotita e magnetita na borda

fot. 40 . afloramento $\mathrm{KJ} 413$, seção polida KJ413f - hornblenda- biotita gnaisse; textura granoblástica; microclinio em grão poligonais na matriz do gnaisse, associado à biotita e minerais opacos primários e secundários

fot.41. afloramento KJ418, lâmina KJ418a - biotita- hornblenda gnaisse; formação de magnetita e ilmenita a partir de megacristal de hornblenda

fot.42. afloramento KJ418, seção polida KJ418am - biotita- hornblenda gnaisse; magnetita em cristal subédrico, intercrescido com hematita (cristal rosa salmão), ilmenita (cinza escuro) nas bordas de calcopirita, cristais de óxido secundário, $20 \mathrm{x}$

fot.43. afloramento KJ423, seção polida KJ423 - hornblenda- biotita gnaisse; magnetita (cristal maior cinzento azulado), bornita (cristal menor rosado, acima da magnetita), reação com silicato nas bordas e fraturas dos óxidos, $10 \mathrm{x}$

fot.44. afloramento $\mathrm{KJ} 423$, seção polida $\mathrm{KJ} 423 \mathrm{~m}$ - hornblenda- biotita gnaisse; magnetita intercrescida com ilmenita no núcleo do cristal (cinza azulado médio), zonação com magnetita alterada nas bordas, magnetita em cristais com reflexão interna no lado direito do cristal, óxidos de alteração na borda superior e fratura, $20 x$

\section{Prancha 9) Fotomicrografias}

fot.45. afloramento $\mathrm{KJ} 387$, lâmina $\mathrm{KJ} 387 \mathrm{t}$ - granada granulito; textura típica granolepidoblástica, foliação principal gerada pela biotita, granada na foliação

fot.46. afloramento $\mathrm{KJ} 387$, lâmina $\mathrm{KJ} 387 \mathrm{C}$ - biotita- hornblenda- granada gnaisse; crescimento de agregados de biotita e hornblenda.

fot 47. afloramento $\mathrm{KJ} 384$, lâmina $\mathrm{KJ} 384 \mathrm{~b}$ - biotita- hornblenda- gnaisse; rocha em contato com o litotipo anterior, mas sem ortopiroxênio. Cristal de anfibólio cinzaesverdeado apresentando cristais de biotita de segunda geração cristalizando nas suas fraturas e bordas e, minerais opacos de primeira (magnetita inclusa) e segunda (opaco entre os cristais de biotita) geração associados

fot.48. afloramento KJ446, lâmina KJ446b2 - granada- biotita gnaisse; granada rosada, fraturada e corroída nas bordas, sendo substituída por biotita; textura poiquiloblástica evidenciada pelas inclusões de minerais opacos biotita e quartzo nas fraturas dos cristais de granada

fot.49. afloramento KJ394, lâmina KJ394s - biotita- hornblendam sillimanita gnaisse; cristais de sillimanita associados a biotita e minerais opacos, em matriz de quartzo, felsdpato e plagioclásio

fot.50. afloramento KJ420, seção polida KJ420 - granitóide porfirítico migmatizado; magnetita (em cristal maior cinza- azulado) com exsoluções de hematía (cinza rosada) e cristais menores cinza azulados, ilmenita com lamelas de magnetita em cristais cinzentos inclusos na magnetita e nas bordas e em ripas alinhadas diminutas no interior do cristal de magnetita, $10 x$

fot.51. afloramento KJ413, seção polida KJ4133 - hornblenda biotita gnaisse; calcopirita (amarelo forte, levemente zonado), e alteração de sulfeto no centro e borda do cristal, $20 x$ 
fot.52. afloramento KJ417, lâmina KJ4173b - biotita hornblenda gnaisse com muscovita; cristal subédrico de hormblenda associado a minerais opacos subédricos, plagioclásio, biotita e quartzo

\section{Prancha 10) Fotomicrografias}

fot.53. afloramento KJ417, seção polida KJ4173d - biotita-granada gnaisse; exsoluções de hematita e magnetita, bordas de alteração com bornita (azul claro), goethita (cinza azulado claro com tintas rosadas), calcopirita (amarelo claro) na borda inferior esquerda, imersa em goethita e em contato com ferro (vindo da alteração da bornita), $20 \mathrm{x}$

fot.54. afloramento $\mathrm{KJ} 430$, seção polida $\mathrm{KJ} 430$ - granito milonitizado; magnetita com exsoluções de ilmenita em cristais cinza azulados menores, rodeados por óxidos de alteração, bornita (rosado) e calcopirita (amarelo claro), no cristal maior, covelina em cristal azulado (canto superior direito), 20x

fot.55. afloramento KJ415, seção polida KJ415c - granito foliado; pirita (amarelo forte) calcopirita (amarelo pálido no centro), bornita (rosa-azulado) e alterações dos sulfetos nas bordas e contatos com o silicato.

fot.56. afloramento KJ415, seção polida KJ4151 - granito foliado; pirita (amarelo forte) euédrica, alterada no bordo direito, $20 \mathrm{x}$

fot.57. afloramento $\mathrm{KJ} 420$, seção polida $\mathrm{KJ} 42 \mathrm{Oh}$ - granito (em contato com biotitahornblenda- granada gnaisse); hematita (cinza claro) no centro de cristal zonado e alterado, ilmenita e calcopirita (amarelo) nas bordas, texłura de reação nos bordos do cristal por migração do ferro, $20 \mathrm{x}$

fot.58. afloramento $\mathrm{KJ} 384$; lâmina $\mathrm{KJ} 384 \mathrm{~d}$ - granada granulito; ortopiroxênio em cristal típico deste litotipo, óxidos e biotita nas fraturas

fot.59. afloramento $\mathrm{KJ} 390$, lâmina $\mathrm{KJ} 390$ - granada granulito; porfiroblasto de hornblenda cristalizado sobre a granada, associado a cristais de magnetita nas bordas e como inclusão

fot.60. aftoramento $\mathrm{KJ} 385$, lâmina $\mathrm{KJ} 385 \mathrm{c} 4$ - biotita granada gnaisse granulítico; formação de ortopiroxênio seguindo a direção do fraturamento em granada, presença de óxidos nas fraturas da granada e biotita nas bordas e fraturas 


\section{Introdução e objetivos}

A evolução tectônica de áreas complexamente deformadas, como faixas de dobramentos associadas à zonas de cisalhamento, pode ser avaliada com eficiência quando enfatizamos a análise cinemática nos estudos de geologia estrutural.

A análise cinemática permite identificar a direção e o sentido do transporte tectônico nas faixas de dobramento e a direção e sentido de movimento nas zonas de cisalhamento, através da interpretação de estruturas características como as foliações, lineações e indicadores cinemáticos.

A ASM tem seido utilizada com sucesso na análise estrutural, pois é uma técnica que possibilita a obtenção de dados sobre o par foliação/lineação magnéticas, de forma rápida e não destrutiva, em rochas aparentemente isotrópicas e, a associação destes dados com os verificados em campo, permite visualizar o comportamento cinemático da área enfocada. (Hrouda \& Janak, 1976, Hrouda,1982, 1993; Borradaile, 1987, 1988, 1991; Archanjo, 1993; Gleizes et al., 1993; Bouchez, 1997, 2000 e Archanjo et al., 1999).

A área estudada está localizada na Faixa Ribeira (Almeida et al., 1973), num setor que abrange parte do leste do estado de Minas Gerais e oeste do estado do Rio de Janeiro. O comportamento estrutural da região apresenta evidências de tectônica transpressional (Ebert et al., 1991, 1998; Machado \& Endo, 1993) e, a feição estrutural proeminente é o Lineamento Além Paraiba (Almeida et al., 1976).

As litologias aflorantes na área deste trabalho consistem de rochas de alto grau metamórfico, predominantemente granulíticas, onde os marcadores cinemáticos visiveis são escassos, justificando a aplicação da ASM em sua análise estrutural.

O enfoque deste trabalho está na aplicação da técnica da ASM para a análise cinemática de rochas de alto grau metamórfico, como as presentes na área desta dissertação, para visualizar o comportamento cinemático local.

Como complemento, visa descrever os procedimentos de obtenção, tratamento e análise dos dados de ASM para aplicação especifica em que esta técnica foi utilizada, durante o presente trabalho.

\subsection{Localização geográfica}

A região sob estudo está localizada na divisa dos estados de Minas Gerais e Rio de Janeiro e, balizada pelas cidades de Laranjal (MG) e Santo Antônio de Pádua (RJ) ao sul 
e, Muriaé (MG) e Retiro do Muriaé (RJ) ao Norte, perfazendo uma área aproximada de $2.700 \mathrm{~km}^{2}$ cujas coordenadas geográficas são $21^{\circ} 05^{\prime} \mathrm{S}-21^{\circ} 25^{\prime} \mathrm{S}$ e $42^{\circ} 5^{\prime} \mathrm{W}-42^{\circ} 20^{\prime} \mathrm{W}$.

As vias de acesso à área são: BR-116, (São Paulo - Laranjal - Muriaé); BR-116 e MG-285 (Laranjal - Miracema); BR- 356, (Muriaé - Retiro do Muriaé); RJ-116, (Retiro do Muriaé - Santo Antônio de Pádua), várias estradas estaduais, vicinais e acessos (fig.1.1.).

Nos trabalhos de campo, na amostragem e na elaboração das principais seções geológicas foram utilizadas folhas do IBGE, em escala 1:250,000: folha de Juiz de Fora, (SF-23XD), 1980; em escala 1:50.000: folhas de: Muriaé (MI-2648/1), 1976; Eugenópolis (MI-2648/2), 1978; Palma, (MI-2648/3), 1976 e Miracema, (MI-2648/4), 1976 e imagem TM Landsat - 5: 217,173226-121539-4, na escala 1:500.000.

\subsection{Contexto geológico regional}

A área de pesquisa pertence ao contexto geológico da Província Mantiqueira (Almeida, 1977, Almeida et al., 1981) e está localizada na Faixa Ribeira (Almeida et al., 1973), caracterizada como um cinturão complexo de dobramentos e empurrões gerado no Neoproterozóico, durante o Ciclo Brasiliano, a sul-sudeste do Cráton do São Francisco (Cordani et al., 1973; Hasui et al., 1975, Hasui, 1982).

As litologias aflorantes na área pertencem predominantemente ao Complexo Juiz de Fora, primeiramente caracterizado por Ebert (1956, apud Dehler, 1996) e, mais tarde definido por Barbosa \& Grossi Sad (1983) como a associação de duas unidades litológicas a saber: Unidade Comendador Venâncio, constituída essencialmente de granulitos, charnockitos, biotita gnaisses granulíticos e quartzitos associados e, Unidade Raposo, constituída de gnaisses granulíticos derivados diretamente das rochas da série charnockítica.

Subordinadamente afloram litologias pertencentes ao Complexo Paraíba do Sul, primeiramente estudado por Ebert (1955, apud Dehler, 1996) e mais tarde definido por Brandalise et al. (1976, apud Barbosa \& Grossi Sad, 1983) como constituído de gnaisses com biotita, hornblenda e granada, metamorfisados na fácies anfibolito, zona da granada.

Maior detalhamento da caracterização petrográfica destes Complexos pode ser obtido em Oliveira $(1980,1981,1983)$ e Machado Filho et al. (1983).

Localizadamente, no setor norte da área, ocorrem afloramentos do Gnaisse Eugenópolis, caracterizado por Rosier (1965, apud Machado Filho et al.,1983) e definido por Machado Filho et al. (1983) como uma unidade litológica constituida por migmatitos, biotita gnaisses e biotita-muscovita xistos, ricos em pegmatitos. 

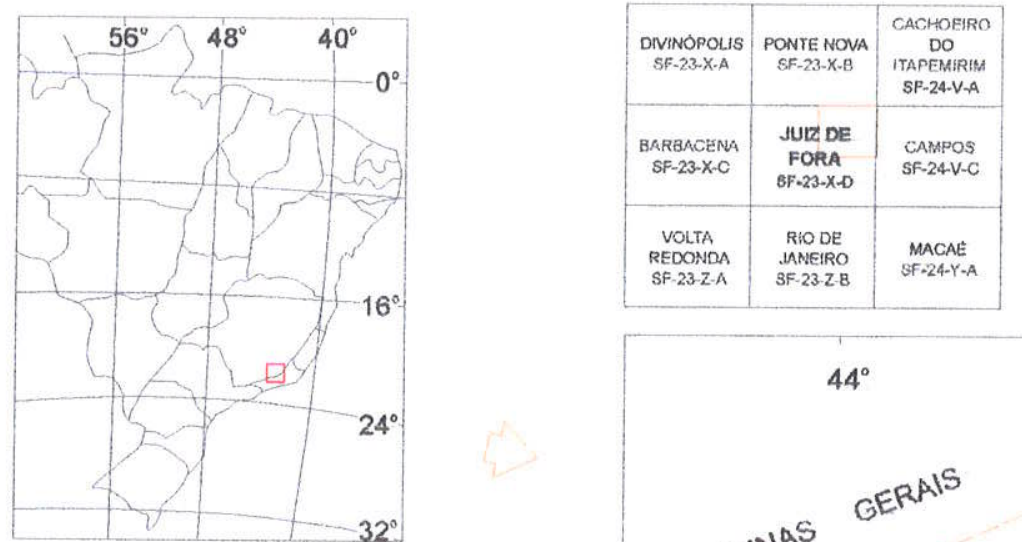

\begin{tabular}{|c|c|}
\hline $\begin{array}{l}\text { MURIAE } \\
\text { Mi-264BDI } \\
\text { IBGE-1976 }\end{array}$ & $\begin{array}{l}\text { EUGENOPOL.IS } \\
\text { MI-2688/2 } \\
\text { IBGE-1978 }\end{array}$ \\
\hline $\begin{array}{l}\text { PaL Ma } \\
\text { M1.2648/3 } \\
\text { IBGE- }\{976\end{array}$ & $\begin{array}{l}\text { MIRACEMA } \\
\text { M1.2648/4 } \\
\text { IBGE-1976 }\end{array}$ \\
\hline
\end{tabular}
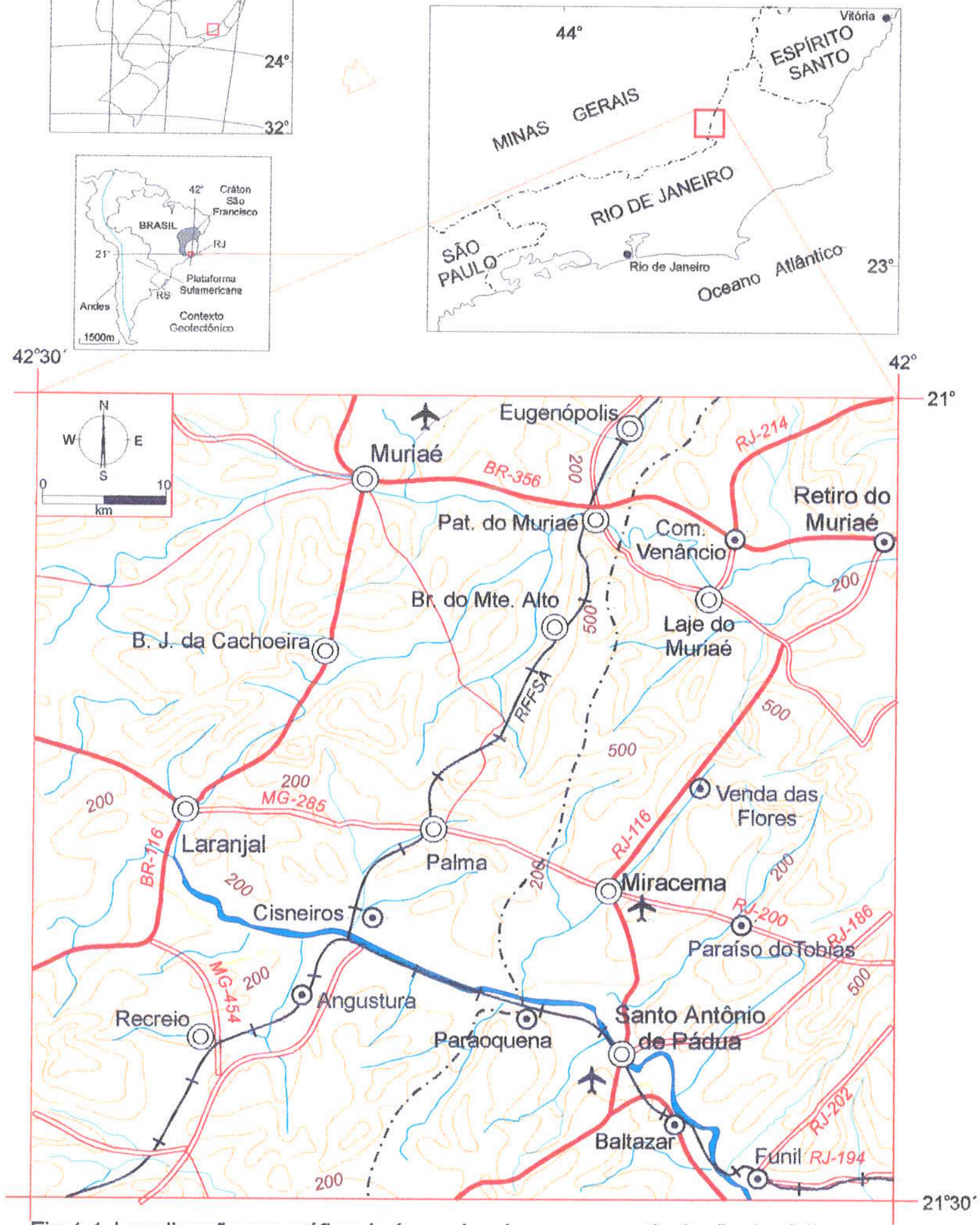

Fig.1.1. Localização geográfica da área, vias de acesso e articulação das folhas. (detalhe do mapa de Fonseca et al. (1979) - escala original 1:1.000.000) 
Rochas granitóides da Suíte Intrusiva Espírito Santo, afloram em contato tectônico com o Gnaisse Eugenópolis e litologias do Complexo Paraíba do Sul. Esta Suíte foi proposta informalmente por Machado Filho et al. (1983), representada por rochas granitóides graníticas a granodioriticas, sin a pós- tectônicas ao Ciclo Brasiliano, semelhantes aos granitóides da Suíte Serra dos Órgãos, que afloram no Rio de Janeiro.

O padrão geocronológico regional evidencia idades arqueanas a paleoproterozóicas com retrabalhamento no Ciclo Brasiliano, para as rochas do Complexo Juiz de Fora e do Complexo Paraíba do Sul (Cordani \& Teixeira, 1979; Siga Jr. et al., 1982, 1989; Hasui \& Oliveira, 1984; Sölner et al., 1991 (apud Machado et al., 1996); Machado et al., 1996; Brüeckner et al. 2000).

O Gnaisse Eugenópolis apresenta idade paleoproterozóica (Machado Filho et al., 1983) e retrabalhamento no Ciclo Brasiliano (Delhal et al., 1969), há 521 M.a. (K/Ar em biotita, granada gnaisse), $462 \mathrm{M}$.a. (K/Ar em biotita, intrusiva metabásica) e idade K/Ar em plagioclásio de 1570 M.a.

As rochas da Suite Intrusiva Espírito Santo reportaram idade neoproterozóica (Delhal et al., 1969) de 600 M.a. (isócrona Rb/Sr, RT, Ri=0,709, granito) e 453 M.a. (K/Ar em biotita, granitóide gnaissificado).

Machado et al. (1996) obtiveram idades arqueanas (2.9 G.a.) para os protólitos do embasamento na região e, idades transamazônicas (2.1 G.a.) para as rochas gnáissicas e granulíticas deste embasamento. Estes autores reportaram que as rochas do embasamento granulítico (Complexo Juiz de Fora) e as rochas supracrustais associadas (Complexo Paraíba do Sul) foram retrabalhadas em eventos de idade brasiliana. O evento que remobilizou a região há 590-565 M.a. seria responsável pela tectônica de empurrão e pelo desenvolvimento das zonas de cisalhamento dextrais ali presentes. Obtiveram também registros de um evento metamórfico há 535-520 M.a. e de atividades tardi a póstectônicas há 503-492 M.a..

Brüeckner et al. (2000), em seção transversal E-W, próxima à área do presente trabalho, obtiveram idade brasiliana para o metamorfismo granulítico que afetou o Complexo Juiz de Fora, (Sm/Nd) 575 M.a., com Tom 1,6 a 2,0 G.a..

Os domínios lito-estruturais verificados em escala regional apresentam divergências na literatura referentes a nomenclatura e limites geográficos (Oliveira, 1980, 1983; Campos Neto \& Figueiredo, 1990, 1992, 1995; Heilbron, 1993; Heilbron et al., 1994, 1995, 1999; Machado, 1997; Machado et al., 1993, 1993b, 1994, 2000). 
A área de estudos do presente trabalho está localizada predominantemente no contexto do Domínios Juiz de Fora e, em seu extremo sul, no contexto do Domínio Paraíba do Sul, ambos propostos por Machado \& Demange, 1994 (fig.1.2.).

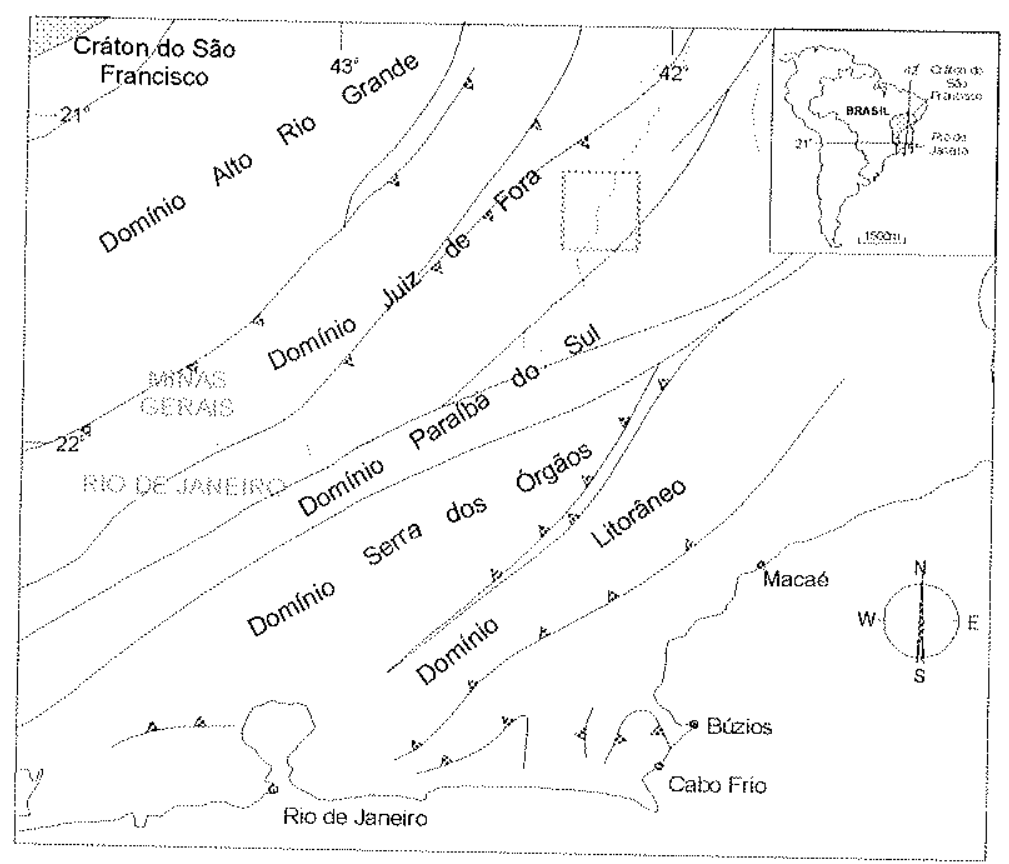

Fig.1.2. Mapa dos domínios tectono-estruturais do sudeste do Brasil (Machado \& Demange, 1994). A área do presente trabalho está localizada predominantemente no Domínio Juiz de Fora, com pequena porção, no extremo sudeste, localizada no Domínio Paraíba do Sul.

O padrão estrutural e cinemático da área do presente trabalho mostra evidências de forte inflexão, com alteração do padrão estrutural regional. Este padrão cinemático varia de direções estruturais NE-SW, associadas à transcorrências, com orientação estrutural característica da Faixa Ribeira, para direções estruturais que infletem até NS, mostrando cinemática de deslocamentos perpendiculares ao trend regional (Brenner et al., 1980).

Campos Neto \& Figueiredo $(1990,1995)$ definiram três domínios crustais distintos para a Faixa Ribeira, na área dos estados de RJ-MG-ES. Estes domínios teriam ocorrido como terrenos unidos durante a evolução de uma microplaca continental no Cambriano.

Segundo estes autores, o primeiro terreno consiste das rochas retrabalhadas do Domínio Juiz de Fora onde ocorre a transição entre as fácies anfibolito e granulito. Este terreno teria se consolidado durante o Paleoproterozóico e evoluído no Neoproterozóico, sob regime convergente, para uma margem continental ativa, com estabelecimento de um arco magmático continental. O Domínio Paraiba do Sul, constituído por rochas supracrustais e o Domínio Costeiro, constituído por rochas granitóides e migmatíticas seriam os outros dois terrenos suspeitos. 
A junção destes três terrenos, no Cambriano, teria formado uma microplaca que cavalgou o Cráton do São Francisco. Este evento foi seguido de plutonismo no CambroOrdoviciano e representaria os estágios finais de um ciclo tectônico na região.

Campos Neto e Figueiredo (op.cit.) consideraram o Complexo Juiz de Fora litologicamente composto de ortogranulitos migmatíticos e gnaisses migmatíticos cinzentos do Proterozóico Inferior, afetados por retrabalhamento e granulitização no Proterozóico Médio-Superior. O metamorfismo na fácies granulito seria sintectônico à foliação regional e, as rochas supracrustais estariam empurradas para oeste na direção do Cráton do São Francisco.

Ebert et al. (1991, 1993, 1993b, 1994, 1998) propuseram que a evolução tectônica da Faixa Ribeira pode ser dividida em dois eventos tectônicos principais, sendo o primeiro evento de natureza tangencial, marcado por falhamentos de empurrão que causaram o cavalgamento dos blocos superiores para WNW e o segundo evento, marcado pelo desenvolvimento de um sistema de zonas de cisalhamento transcorrentes de sentido dextrógiro, que retrabalhou as rochas da área, afetando a fábrica gerada durante o evento tangencial.

Consideraram que o arcabouço geotectônico da borda sul do Cráton do São Francisco e as feições estruturais que ali ocorrem seriam devidas à articulação de três blocos crustais, Brasilia, São Paulo e Vitória, através de um processo compressivo principal de direção E-W.

Observaram que há um decréscimo nas condições de metamorfismo nos terrenos afetados por este cinturão transcorrente, de norte para sul, indicando um provável soerguimento diferencial das rochas ali situadas.

As zonas de cisalhamento transcorrente, de médio a alto ângulo, particularmente ao longo do Rio Paraíba, constituiriam estrutura em flor assimétrica, com mergulho para sudeste e, poderiam estar conectadas em profundidade com uma grande zona de descolamento.

Neste contexto, as zonas de cisalhamento de médio a baixo ângulo poderiam representar tanto os estágios iniciais da evolução tectônica da Faixa Ribeira, rotacionados pela transcorrência, quanto corresponder a subdominios de cavalgamentos laterais produzidos pela tectônica dextrógira.

Para Ebert e colaboradores, a tectônica de escape lateral proposta em Vauchez (op cit.) não precisa ser invocada para explicar o arcabouço estrutural presente no sudeste brasileiro, pois evidências de dados obtidos em campo e modelagem experimental mostraram que o Bloco São Paulo já teria formato acunhado quando de seu avanço para 
leste e posterior ajuste com os Blocos Brasília e Vitória. Isto possibilitaria a concentração da convergência através da partição da deformação entre transcorrências e encurtamentos crustais obliquos, sob tectônica transpressional.

A interpretação dinâmica entre estes três blocos crustais, ajustados entre suas margens convergentes, favorece a hipótese de que estes blocos tenham se individualizado a partir da ruptura de um anterior grande bloco continental, ao longo de uma junção tríplice.

O modelo tectônico reproduzido experimentalmente por Ebert et al. (1993), onde três bacias longitudinais estiveram interligadas durante sua evolução e inversão, explica a área de exposição e a difícil delimitação entre as litologias da Faixa Alto Rio Grande e da Faixa Ribeira, na intersecção destes cinturões.

Segundo Vauchez et al. $(1992,1994)$, o comportamento estrutural da Faixa Ribeira seria resultante da colisão frontal da extremidade S-SW da placa Cráton do Congo-Cráton São Francisco com a mega-placa do Gondwana Ocidental, durante o Ciclo Brasiliano, representando um caso de controle do campo deformacional pela influência da terminação sul do Cráton do São Francisco. Esta colisão teria provocado os falhamentos de empurrão presentes na área e a instalação das zonas de cisalhamento dextrógiras que acomodaram a deformação causaram a tectônica de escape lateral para S-SW, das massas rochosas envolvidas durante o processo de colisão.

Strieder (1993), através de análises detalhadas de estruturas lineares nas Províncias Estruturais Tocantins e Mantiqueira, observou que a Cunha de Guaxupé está truncada pelas estruturas ligadas ao processo colisional da Orogênese Rio Doce (Campos Neto \& Figueiredo, 1992).

Estas estruturas, extensas zonas de cisalhamento direcional dextrógiro, correlatas à Zona de Cisalhamento Paraíba do Sul, seriam decorrência natural da aproximação e colisão oblíqua de blocos continentais, Blocos São Paulo, Brasília e Vitória, (N.A.: propostos por Ebert et al., op cit.) e, não o resultado da colisão e justaposição de bloco irregular (N.A: Cráton do Congo) com a terminação de cráton antigo (N.A: Cráton do São Francisco), como proposto em Vauchez et al. $(1992,1994)$.

Para Strieder (op cit.), a aproximação e colisão do Cráton do Congo para originar a Província Estrutural Mantiqueira encontrou a Província Estrutural Tocantins já estabelecida, na Cunha de Guaxupé (localizada à sudoeste da área deste dissertação).

Em grande escala, a aproximação do Cráton do Congo com o bloco continental formado pelos crátons do São Francisco - Guaporé interporia bordas continentais não combináveis, resultando numa diferenciação do proceso colisional: convergência frontal no 
segmento Norte (N.A.: próximo à área do presente trabalho) e convergência oblíqua no segmento Sudoeste da Província Estrutural Mantiqueira.

Heilbron, 1993 e Heilbron et al. (1994, 1994b, 1995) propuseram uma evolução tectono-metamórfica para o setor central da Faixa Ribeira, envolvendo convergência crustal através de dobramentos e empurrões sob regime dúctil e, estágios tardios de convergência oblíqua, com deformação distribuída regionalmente.

Os autores apresentaram uma subdivisão para a Orogênese Brasiliana em períodos abrangendo as fases deformacionais que afetaram as litologias dos Complexos Juiz de Fora, Paraíba do Sul e Costeiro, na parte central da Faixa Ribeira.

Estes períodos seriam: período sin-colisional (590-563 M.a.), onde a deformação principal causou o empilhamento tectônico e posterior movimentação oblíqua (inversa e dextral), com metamorfismo de pressão média a alta e zoneamento metamórfico inverso; período pós-colisional (535-520 M.a.), relacionado à deformação tardia responsável pela implantação das zonas de cisalhamento direcional dextrais, metamorfismo com regime de pressão mais baixo e fusão parcial do embasamento e rochas supracrustais da porção mais interna da faixa e, período pós-tectônico (503-402 M.a.) caracterizado pela transição do regime compressivo para o regime distensional dominante no Fanerozóico, com a geração dos granitóides que ocorrem associados às rochas da região.

Machado \& Endo (1993, 1993b, 1994), Endo \& Machado (1993, 1993b) e Machado \& Demange (1994) propuseram um modelo estrutural e cinemático, em dois estágios evolutivos, para a porção central da Faixa Ribeira, porção esta que abrange a área do presente trabalho.

O modelo de Machado e colaboradores (op.cit.) considera um padrão cinemático desenvolvido durante o período brasiliano, atuando num cinturão do tipo transpressivo e, envolvendo convergência lateral oblíqua com alteração da orientação dos vetores tectônicos transpressivos mudando de E-W para N-S.

A convergência frontal, observada na porção setentrional do Cinturão de Cisalhamento Atlântico, na altura do médio Vale do Rio Doce, teria origem pelo efeito do extrusão tectônica lateral positiva promovida pelos movimentos transpressivos dextrógiros oriundos da zona focal do Cinturão de Cisalhamento Atlântico.

Uma posterior inversão do regime cinemático regional teria possibilitado a implantação do ambiente transtensional que favoreceu a ascensão e colocação de magmas graníticos neste cinturão no intervalo de 620-550 M.a..

Este modelo evolutivo estrutural implica em acresção lateral e extrusão tectônica vertical de massa rochosa, associadas a uma tectônica de acresção longitudinal em 
relação aos sistemas de cisalhamento circundantes. O vetor compressivo (E-W) é interpretado como produto de tectônica transpressional dextrógira, que teria gerado o arranjo geométrico e cinemático das zonas de cisalhamento presentes na região.

Este componente transpressivo dextrógiro seria responsável pela colagem tectônica lateral dos terrenos da Cunha de Guaxupé com os do Sistema de Cisalhamento Paraíba do Sul, desenvolvendo nestes terrenos uma trama estrutural dúctil penetrativa.

O arcabouço estrutural da região seria produto de reativação, que estaria controlada pelas estruturas pré-existentes, com o vetor compressivo não-coaxial (transpressional levógiro) orientado segundo direção N-S.

Estes autores consideraram que as transcorrências que ocorrem na Faixa Ribeira, consideradas pós- tectônica de empurrão (D3) por outros autores que trabalham na região, não seriam tardias ao processo colisional mas, de instalação precoce na evolução desta faixa.

A região focal da deformação transpressiva estaria situada no Sistema de Cisalhamento Paraíba do Sul, na zona focal do Cinturão de Cisalhamento Atlântico, altura do Rio de Janeiro e, seria a causadora do escape rochoso lateral e vertical, seguindo o esquema de mega-estrutura em flor positiva e gerando os empurrões nas partes externas do orógeno.

O contexto geológico regional pode ser composto, com maior detalhamento, a partir das referências bibliográficas dos trabalhos citados e da revisão bibliográfica no Anexo 1 .

\subsection{Contexto geológico local}

O Complexo Juiz de Fora ocorre em faixas alongadas de direção NE-SW, desde São Paulo ao Espírito Santo e do Rio de Janeiro a Minas Gerais e suas associações litológicas predominam na área deste trabalho.

Esta unidade é constituída por rochas metamórficas das fácies granulito e anfibolito alto, localmente migmatizadas, representadas por gnaisses enderbíticos e charnoenderbíticos, granada gnaisses granulíticos, granulitos e charnockitos.

As rochas deste complexo apresentam aspecto maciço e homogêneo, com coloração escura, nos granulitos e charnockitos $e$, aspecto bandado e cinzento nos gnaisses e migmatitos da porção central. Ocorrem lentes de anfibolito, mármore e veios de quartzo.

Na porção centro-sul e sudeste da área ocorrem intercalados orto e paragnaisses granulíticos do Complexo Juiz de Fora com gnaisses miloníticos pertencentes ao 
Complexo Paraíba do Sul, através de contatos tectônicos por transcorrências e falhamentos de empurrão.

O Complexo Paraíba do Sul ocorre intercalado ao Complexo Juiz de Fora, também em faixas alongadas de direção NE-SW, desde São Paulo ao Espírito Santo e do Rio de Janeiro a Minas Gerais.

Esta unidade é composta de rochas de origens sedimentar e ígnea, como granada gnaisses, anfibólio-biotita gnaisses, sillimanita gnaisses e rochas cálcio-silicáticas, metamorfisadas na fácies anfibolito.

As litologias apresentam aspecto bandado, coloração clara a cinzenta, ocorrendo na parte sul-sudeste e limite leste da área, onde afloram gnaisses com microclínio, biotita e hornblenda, intercalados com granada gnaisses em lentes de orientação preferencial nordeste, em contatos tectônicos entre si e com as litologias do Complexo Juiz de Fora.

Localmente, em afloramento no centro da área e no limite norte, ocorre biotitamuscovita gnaisse, cinzento e localmente migmatítico, pertencente ao Gnaisse Eugenópolis.

Rochas granitóides pertencentes ao contexto da Suite Intrusiva Espírito Santo, afloram na parte sul-sudeste da área, próxima a Santo Antônio de Pádua e no limite norte. Esta suíte é constituída de granitóides, localmente foliados, miloníticos e hidrotermalizados. Ocorrem intrusivos nas litologias dos Complexos Paraiba do Sul e Juiz de Fora e Gnaisse Eugenópolis.

$\mathrm{Na}$ área abrangida pelo presente estudo ocorrem migmatização, milonitização e sulfetos secundários, associados às estruturas de empurrão e às zonas de transcorrência.

Enclaves de granulitos e de gnaisses granulíticos, corpos graníticos intrusivos e veios de quartzo ocorrem esparsos, bem como lentes de anfibolito e diques aplíticos, com orientação preferencial NE.

Para detalhamento, veja Mapa Geológico (Anexo 3). 


\section{Metodologia de trabalho}

Neste capítulo estão apresentados os procedimentos de amostragem, trabaihos de campo, equipamentos e métodos de laboratório (Cap.2.1.), utilizados para a análise petrográfica, estrutural e de ASM da área desta dissertação.

Os conceitos de análise cinemática, caracterização dos marcadores cinemáticos foram sintetizados e brevemente descritos (Cap.2.2.).

Propostas atuais, em acordo com um modelo evolutivo regional de tectônica transpressiva (Ebert et al., 1988,1991; Machado \& Endo, 1993), justificam a breve evolução sobre os conceitos de regime transpressional, feita neste capítulo. $O$ modelo evolutivo regional que melhor representou as conclusões obtidas para a área, através dos dados obtidos na presente dissertação, foi detalhado em Ebert \& Hasui (1998).

Os procedimentos de amostragem específicos e tratamento dos dados obtidos pela técnica da ASM estão descritos e ilustrados, considerando a abordagem da técnica adotada nesta dissertação. Foram apresentados alguns conceitos básicos de magnetismo, susceptibilidade magnética, anisotropia de susceptibilidade magnética, elipsóide e parâmetros de ASM que foram utilizados (Cap.2.3.).

A identificação dos minerais magnéticos presentes nas rochas foi feita através de métodos convencionais no microscópio petrográfico e, foi apresentada uma breve caracterização dos minerais magnéticos identificados nas rochas da área (Cap.2.3.3.2.).

\subsection{Trabalho de campo, amostragem e petrografia.}

O trabalho de campo foi precedido de revisão bibliográfica dos trabalhos anteriores (Anexo 1) e teve como base cartográfica os mapas referidos no capítulo anterior.

As seções geológicas, convenientemente orientadas em relação ao trend regional, proporcionaram a cartografia preliminar dos marcadores estruturais da área em escala 1:100.000 e a coleta das amostras, durante a etapa de campo, para os estudos posteriores de petrografia, análise estrutural, cinemática e de ASM.

Foram amostrados e estudados 73 afloramentos, dos quais 49 foram amostrados também para ASM (Mapa de Pontos, fig.4.1.). As análises foram feitas em 51 lâminas delgadas, 21 seções polidas, 16 difratogramas de raios- $X$ e 426 cilindros de rocha para análise de ASM.

Os estudos petrográficos foram feitos através de microscópio petrográfico com luz transmitida e com luz refletida para a identificação das assembléias minerais e texturas.

A petrografia foi complementada com análises de difratometria de raios- $X$ realizadas 
em equipamento Slemens-Brukes, D-5.000 nas condiçöes: $40 \mathrm{KW}$ e $40 \mu \mathrm{Amp}, 3$ a $65^{\circ}$ (20), passo de $0.05^{\circ}(2 \theta)$, tempo de amostragem de 1,0 seg em amostras de 200 mesh (Difratogramas, Anexo 2).

O mapa geológico resultante (Anexo 3) representa a integração dos dados obtidos em campo e laboratório, associados aos mapas de Oliveira (1980, 1983), Barbosa et al. (1981) e Machado Filho et al. (1983).

\subsection{Análise estrutural e cinemática}

A compreensão da evolução evolução geológica e tectônica de uma região localizada em uma faixa móvel e afetada por tectônica tangencial e transcorrente como a área em estudo, passa pela observação das estruturas mais representativas da sua evolucão cinemática e pelo estudo do provável ambiente tectônico causador dos processos deformacionais que atuaram nesta região.

Os métodos de análise estrutural geométrica e cinemática, com análise de indicadores cinemáticos, foliações, lineações e uso das relações geométricas encontradas, possibilitam elaborar um quadro do comportamento mecânico das rochas, caracterizando os domínios estruturais e suas transiçoes.

A caracterização dos princípios da análise cinemática e do regime transpressional foi abordada neste capítulo visando fundamentar a metodologia de estudo e tratamento dos dados utilizada nesta dissertação e; considerando as possibilidades de interpretação para o comportamento estrutural da área, em vista dos dados obtidos durante o presente. estudo e dos dados existentes na literatura.

o método de análise cinemática evoluiu a partir do estudo experimental dos processos da deformação, comparando estados iniciais e finais de sistemas de forças conhecidos, que possibilitam compreender a evolução geológica de uma área através de informações sobre os movimentos das massas rochosas (análise cinemática) e sobre as forças que os produziram (análise dinâmica).

A análise estrutural de um objeto deformado pode ser feita através da descricão das características geométricas deste objeto e, estas podem ser interpretadas diretamente com conceitos cinemáticos, considerando que a natureza da ordem geométrica do corpo reflete a ordem geométrica dos deslocamentos e tensões presentes durante a sua deformaça (Nicolas, 1987, apud Tommasi, 1991).

Considerando os estudos sobre zonas de cisalhamento, (revisão completa em Sadowski, 1991), Vauchez (1987, apud Tommasi, 1991) e Tommasi (1991) evidenciam a. importância do cisalhamento simples na deformação, considerado como um regime capaz. 
de produzir movimentos direcionais relativos de grande magnitude e também capaz de acomodar deslocamentos, concentrando a deformação em zonas estreitas em relação à escala considerada -zonas de cisalhamento. Estas zonas delimitam e deslocam os blocos sem participar de modo determinante na sua deformação interna (Nicolas et al., 1977).

A fábrica das rochas afetadas por estes movimentos direcionais pode preservar o registro do regime deformacional, permitindo a identificação deste regime através da análise cinemática.

Os registros da deformação constituem os marcadores cinemáticos, como o plano de foliação (paralelo ao plano xy do elipsóide de deformação) e a lineação mineral (paralela à direção $x$ do elipsóide de deformação). Estes marcadores devem ser observados em seções paralelas à direção de cisalhamento e perpendiculares ao plano de achatamento (plano xz do elipsóide de deformação).

A consistência direcional estatística dos marcadores cinemáticos indica sua confiabilidade como indicadores da direção de fluxo, movimento e transporte tectônico, mesmo considerando a possibilidade de haver rotação de elementos pré-existentes ou neo-formados durante a deformação progressiva (Simpson \& Schmidt, 1983; Passchier \& Simpson, 1987, Passchier \& Trouw, 1997).

Com o aumento do cisalhamento durante a deformação progressiva, a foliação e a lineação de estiramento são rotacionadas na direção do plano de cisalhamento, possibilitando estabelecer a correlação entre os marcadores cinemáticos e os referenciais do cisalhamento: plano, direção e sentido.

Os eixos máximos do elipsóide de deformação finita e as estruturas lineares são sempre "atraídas" (fabric attractors, Passchier, 1997) para a direção de maior fluxo tensional (Fossen, Tikoff \& Teyssier, 1994; Teyssier \& Tikoff, 1999; Tikoff \& Wojtal, 1999).

Considerando que os referenciais cinemáticos e de cisalhamento são muito próximos nas áreas de deslocamentos direcionais, a caracterização da foliação e da lineação de estiramento permite uma aproximação do padrão cinemático presente e, a lineação de estiramento mineral pode ser interpretada como equivalente ao sentido do movimento ou transporte tectônico (Passchier \& Trouw, 1997; Ramsay \& Huber, 1997).

Zonas de movimentação direcional, pouco espaçadas lateralmente, podem coalescer, produzindo um padrão em blocos losangulares, deformados nas bordas e por vezes preservados de deformação no centro.

Segundo Coward (1976) e Coward \& Potts (1983), tais blocos poderiam representar as partes de uma zona de cisalhamento onde ocorreu achatamento normal à zona, com marcadores em alto ângulo em relação à zona de cisalhamento. Isto poderia explicar estruturas em grande escala, como as dobras normais, com deformação por cisalhamento 
simples superimposta e explicariam também a rotação e a deformação das dobras nas zonas de cisalhamento, produzindo transposição e milonitização, com conseqüente encurtamento paralelo às camadas e espessamento crustal (Teyssier \& Tikoff, 1999; Tikoff \& Wojtal, 1999).

A transpressão foi primeiramente conceituada por Harland (1971, apud Machado, 1997) como o regime de deformação presente em zonas de convergência oblíqua de placas (N.A.: semelhante ao proposto para a área do presente trabalho), atuando como intermediário entre a transcorrência e a compressão puras.

Sanderson \& Marchini (1984) redefiniram o conceito de transpressão nos termos da elipse de deformação, baseados em Flinn (Flinn, 1962, apud Ramsay \& Huber, 1997; Flinn, 1979) e, colocaram que o regime de transpressão envolve o cisalhamento puro e o cisalhamento simples combinados.

O regime de deformação compressiva é caracterizado no diagrama de Flinn (op. cit.) por elipsóides oblatos $(K<1)$, enquanto o regime transtrativo é caracterizado por elipsóides prolatos $(K>1)$. Portanto, o achatamento devido ao cisalhamento puro normal ao plano de cisalhamento predomina na transpressão e, o estiramento devido ao cisalhamento simples predomina na transtração.

A lineação de estiramento gerada pela transpressão poderia ser, para Sanderson \& Marchini (op. cit.), horizontal ou vertical e a lineação gerada pela transtração seria horizontal. Ainda segundo este autor, a transpressão envolveria cisalhamento direcional, acompanhado de encurtamento horizontal (normal ao plano de cisalhamento) e estiramento vertical no próprio plano de cisalhamento (ao longo do eixo z). Portanto, o encurtamento perpendicular à zona de cisalhamento seria compensado pelo espessamento vertical, com conservação de volume.

Sengör (1992, apud Machado, 1997) dividiu os cinturões transpressivos em simétricos e assimétricos. Os cinturões transpressivos (orógenos) simétricos seriam os intracontinentais, com polaridade tectônica dupla e rotação de blocos crustais limitados por falhas transcorrentes $e$, os assimétricos poderiam ser tipo intracontinental, tipo intraoceânico ou de margem continental, com polaridade tectônica simples.

Prosseguindo nos estudos sobre o regime transpressional, Fossen \& Tikoff (1993), colocaram que a deformação progressiva das rochas poderia ser explicada pela combinação de cisalhamento simples e cisalhamento puro, com ou sem variação de volume, considerando a orientação dos eixos de deformação finita do elipsóide de deformação com uma função do tipo da deformação atuante na área, transpressiva, transtrativa ou por cisalhamento simples.

Tikoff \& Teyssier (1994) propuseram dois tipos de orógenos transpressionais 
relacionados à convergência oblíqua de placas, conforme a predominância das componentes do cisalhamento puro ou do cisalhamento simples, considerando a importância da partição da deformação neste tipo de ambiente.

Para estes autores, nos orógenos com cisalhamento puro predominante há o desenvolvimento de falhas inversas e de empurrão, acompanhado pela geração de falhas transcorrentes que são responsáveis pela acomodação da deformação direcional, enquanto nos orógenos com cisalhamento simples predominante há o desenvolvimento de falhas transcorrentes, acompanhado pela geração de falhas de empurrão como reflexo da acomodação da deformação decorrente do encurtamento.

Em ambos os casos, falhas direcionais e reversas seriam formadas simultaneamente como partes do mesmo sistema transpressional, como resposta direta ao regime de esforços atuantes na área afetada, sem intervenção da partição da deformação.

O regime de deformação transpressional propiciaria o desenvolvimento de estruturas em flor, positivas na transpressão e negativas na transtração (Machado, 1997).

Evoluindo no conceito de transpressão, Teyssier \& Tikoff (1999) colocaram que, sob regime transpressional, o strain acumulado provoca o achatamento puro até a lineação se tornar vertical, enquanto na transtensão o strain acumulado gera uma fábrica constricional, transformando a foliação de vertical para oblíqua e horizontal, com o aumento da deformação.

Estes autores, através de modelamento tridimensional, seguindo o modelo de transpressão-transtensão (pressupondo deformação homogênea e correlação entre os eixos de deformação finita com o par lineação-foliação nos tectonitos), investigaram os campos de estabilidade de orientação das foliações e lineações em zonas de convergência-divergência oblíquas com ângulos entre 0 e $20^{\circ}$. A estabilidade da fábrica mostrou ser controlada pelo componente coaxial da deformação, considerando a orientação do componente de cisalhamento simples.

Tikoff \& Teyssier (op. cit.) consideraram que, se o carácter da transpressão, extrusão lateral ou mudança de volume numa região é estimado, então uma gama de possiveis ângulos de convergência ou divergência podem ser determinados, possibilitando importantes considerações sobre a tectônica desta região.

Os autores concluíram que, pressupondo deformação homogênea e relação direta entre a deformação e a fábrica da rocha deformada, quando a deformação combina componentes coaxiais e não coaxiais, a estabilidade dos marcadores foliação-lineação nos tectonitos, pode ser controlada pelas apófises de fluxo (fabric atracctors, Passchier, 1997), enquanto a forma e a estabilidade da orientação da fábrica pode ser controlada pelo componente coaxial da deformação. 
Teyssier \& Tikoff (1999) e Tikoff \& Wojtal (1999) verificaram, no modelamento do regime transpressivo, que a presença de foliação vertical e lineação horizontal caracterizam zonas transtensionais ou transpressionais respectivamente mas, com a progressão da deformação finita, a lineação é reorientada progressivamente para a vertical na transpressão e a foliação é reorientada para progressivamente para a horizontal na transtensão, gerando resultantes oblíquas. Concluíram que zonas transpressivas, com escape lateral positivo, estabilizam a lineação próxima à horizontal, sob convergência oblíqua, permitindo o desenvolvimento de lineações próximas a horizontal, mesmo sob convergência oblíqua de alto ângulo.

Diques intrusivos em zonas de transtensão poderiam ainda particionar o componente compressivo da deformação, pois geram constraste de competência no conjunto rochoso (Goodwin \& Tikoff, 2002) resultando em foliação próxima à vertical estável entre os diques. Se estes diques aproveitam principalmente o componente extensional, através de adição anisotrópica de volume, então a foliação sub ou vertical seria estabilizada nas rochas encaixantes, sob baixo strain. Se isto ocorre sob alto strain, então o efeito de estabilidade da foliação vertical seria reduzido, devido ao efeito do componente de cisalhamento puro associado com a extensão.

Considerando que a deformação em áreas policíclicas pode apresentar superposições sucessivas das estruturas associada à deformação heterogênea, Teyssier \& Tikoff (op. cit.) sugeriram que a estabilidade dos marcadores cinemáticos e da fábrica da rocha deve ser considerada com cautela na interpretação tectônica.

Jiang \& Williams (1999) corroboram com as consideraçōes de Teyssier \& Tikoff (1999) sobre a cautela necessária na interpretação tectônica através dos indicadores cinemáticos. Estes autores colocam que a correlação consistente entre estruturas e fábrica observadas na rocha podem apenas sugerir modelos de geração desta fábrica resultante, pois diferentes histórias cinemáticas poderiam produzir o mesmo resultado final.

Jiang \& Williams (op. cit.) consideraram que, desde que o caminho (provável) de fluxo varia com o tempo, para histórias deformacionais irregulares (non-steady), as estruturas e fábrica não deveriam ser interpretadas assumindo direções constantes na direção dos vetores cinemáticos mas, deveriam ser investigados, a priori, a história evolutiva do estiramento e da rotação das linhas materiais ou outros elementos da fábrica, o que envolve o conhecimento dos padrões de deformação que, no caso de evolução temporal irregular (non-steady), não podem ser determinados retroativamente.

Nieto-Samaniego (1999) coloca que não há padrão cinemático que permita a determinação da orientação dos vetores de deslizamento considerando a reativação de planos de fraqueza pré-existentes, geração de novos falhamentos e interação entre 
ambos, o que limita a análise tridimensional de falhamentos com vários sets associados, (e.g. falhamentos com simetria ortorrômbica), o cálculo dos tensores do paleostress e o cálculo da deformação horizontal máxima.

A área do presente estudo é constituída de rochas policíclicas, com diferentes comportamentos reológicos, deformadas em fases e intensidades diferentes que geraram padrões complexos de falhamento $e$, portanto, está sujeita às limitações na análise cinemática inerentes ao seu contexto geológico e características litológicas.

Em vista da complexidade da área estudada e sua posição em relação ao contexto geológico regional, consideramos que sua evolução pode ser investigada, a partir do modelo transpressional atualmente adotado para a região (Ebert et al., 1998 e Campos Neto, 2000) e, através de interpretações associadas das estruturas observadas em campo e pela ASM, que podem sugerir o padrão cinemático local, principalmente nas litologias granuliticas, onde as informações de campo são obtidas com maior dificuldade.

\subsection{Anisotropia de susceptibilidade magnética - ASM}

O magnetismo de rochas é uma ciência fundamentada nos conceitos de ferromagnetismo e domínios magnéticos, cujo estudo e técnicas são uma extensão dos estudos clássicos de materiais magnéticos, principalmente o ferro e seus compostos

As propriedades magnéticas das rochas e seus minerais constituintes proporcionam informações sobre sua formação e evolução física de seus componentes minerais.

As rochas onde a intensidade da magnetização (induzida ou remanescente) dependem da direção do campo aplicado apresentam anisotropia magnética.

A ASM é a quantificação da variação tridimensional da susceptibilidade magnética de um material e a susceptibilidade é uma função direta do campo aplicado.

A ASM pode ser representada por um elipsóide cujos eixos $\mathrm{K} 1$ (eixo maior), K2 (eixo intermediário) e K3 (eixo menor) correspondem respectivamente às susceptibilidades máxima, intermediária e mínima. O eixo maior (K1) é paralelo à orientação preferencial dos eixos maiores dos grãos ferromagnéticos e representa a lineação magnética e, o eixo menor (K3) é normal à orientação preferencial dos eixos menores, correspondendo ao pólo do plano de foliação magnética (Graham, 1954, apud Tarling \& Hrouda, 1993).

Do ponto de vista estrutural, as rochas são anisotrópicas em diversas escalas, desde o afloramento até a seção delgada e, quando analisadas através da ASM, revelam a anisotropia de sua fábrica, que pode ser correlacionada com a fábrica tectônica destas rochas.

$\mathrm{Na}$ deformação contínua (e/ou metamorfismo progressivo) o eixo longo (K1) das 
partículas magnéticas é orientado progressivamente na direção do esforço mínimo. Na deformação por cisalhamento, $\mathrm{K} 1$ é reorientado progressivamente na direção de estiramento das partículas $e$, na tectônica de empurräo, $\mathrm{K} 1$ é normal à direção do plano cujo pólo representa o eixo mínimo (K3) das partículas magnéticas. Estas reorientações de K1 e K3 com relação aos esforços permite que o elipsóide de susceptibilidade magnética possa ser aplicado, em alguns casos, para dedução de informações sobre a deformação dúctil que ocorre sob metamorfismo e deformação progressivos nas rochas (Hrouda \& Janak, 1976).

Neste trabalho foi utilizada a técnica de anisotropia de susceptibilidade magnética sob baixo campo magnético indutor $\left(4 \times 10^{-4} \mathrm{~T}\right)$, em susceptibilímetro do tipo Kappabridge KLY - 3S do laboratório de anisotropia do Instituto de Geociências da USP.

\subsubsection{Amostragem e equipamentos de análise}

\section{- Amostragem}

A malha de amostragem para ASM abrangeu larga extensão da área estudada. A amostragem foi intensificada nas áreas onde os marcadores cinemáticos mesoscópicos estavam escassos ou ausentes, buscando caracterizar as fábricas planar e linear.

A amostragem foi feita com uma perfuratriz portátil movida à gasolina, (fig. 2.1.a.). Os cilindros de rocha foram extraídos com broca de coroa diamantada DTD (fig. 2.1.b.) que, no processo de corte usa uma mistura lubrificante de água e óleo mineral, através de bombeamento manual (fig. 2.1.c.).

Os cilindros de rocha obtidos em campo (fig. 2.1.h.) medem cerca de $12 \mathrm{~cm}$ de comprimento por $2,54 \mathrm{~cm}$ de diâmetro. Cada cilindro é orientado espacialmente através da leitura da direção e mergulho do furo numa bússola acoplada a um suporte cilíndrico de alumínio (fig. 2.1.f.). A atitude obtida é transferida para o testemunho usando um arame de cobre, que risca a rocha através de uma fenda (fig. 2.1.e.).

Os testemunhos são identificados imediatamente à coleta, com caneta de tinta permanente de ponta fina, usando como gabarito $1 / 2$ canaleta de alumínio (fig. 2.1.g.) e traçando uma linha que aponta para o topo da amostra.

As informações referentes ao furo (identificação, posição, litologia, contato, etc.) devem ser anotadas e os testemunhos podem então podem ser transportadas para tratamento posterior. As amostras são cortadas manualmente no laboratório de preparação de amostras em serra apropriada. 

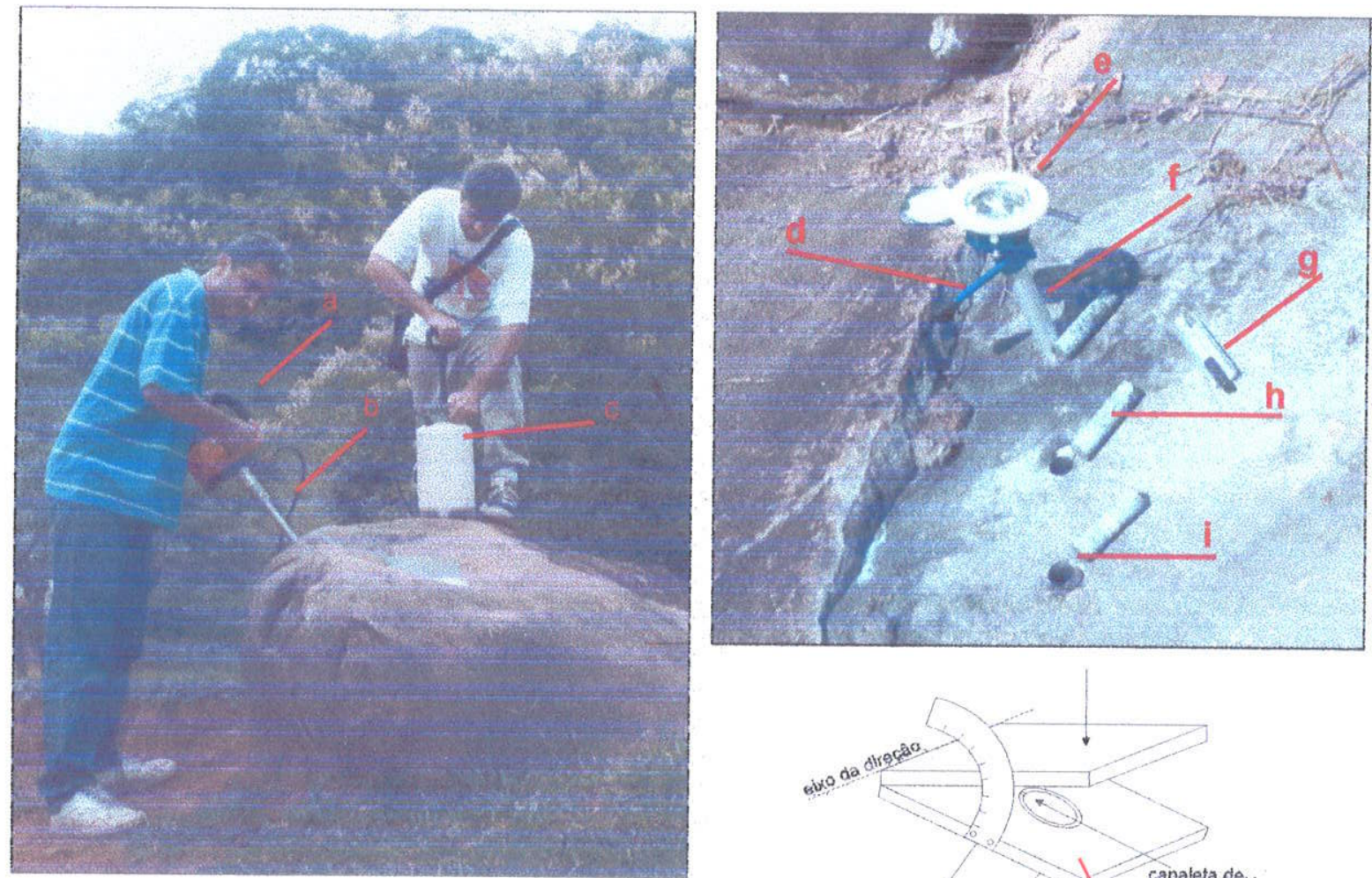

Fig. 2.1. Amostragem para o método de ASM

a) perfuratriz à gasolina; b) sonda de aluminio com coroa

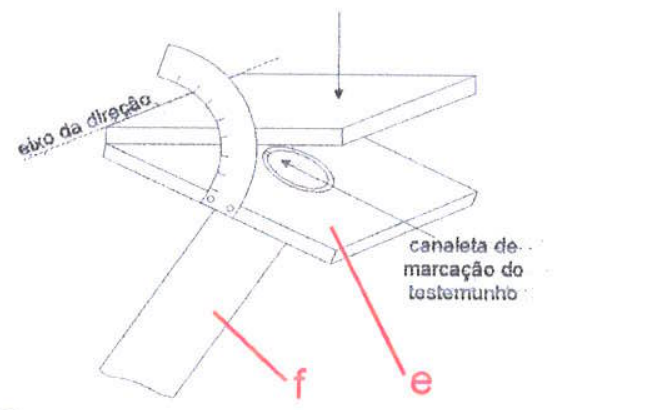
diarnantada; c) reservatório de água com óleo mineral para lubrificação do furo; d) nivelador da bússola; e) suporte para bússola; f) cilindio de alumínio para apoio da bússola e orientação do testemunho; g) canaletas para marcações e orientação do testemunho; h) testemunho retirado do afloramento; i) furo.

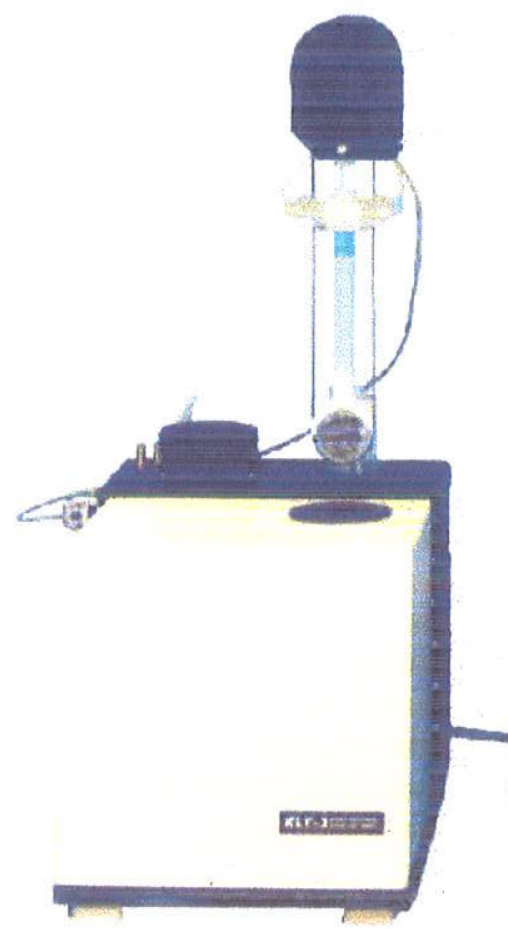

a) unidade de medidas

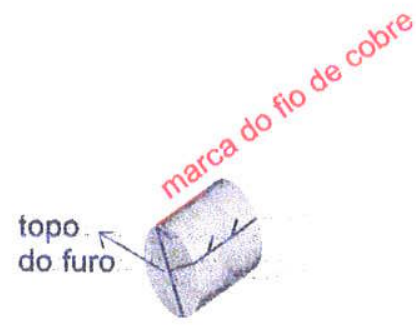

d) amostra cilindrica $2,2 \mathrm{~cm} \times 2,5 \mathrm{~cm}$

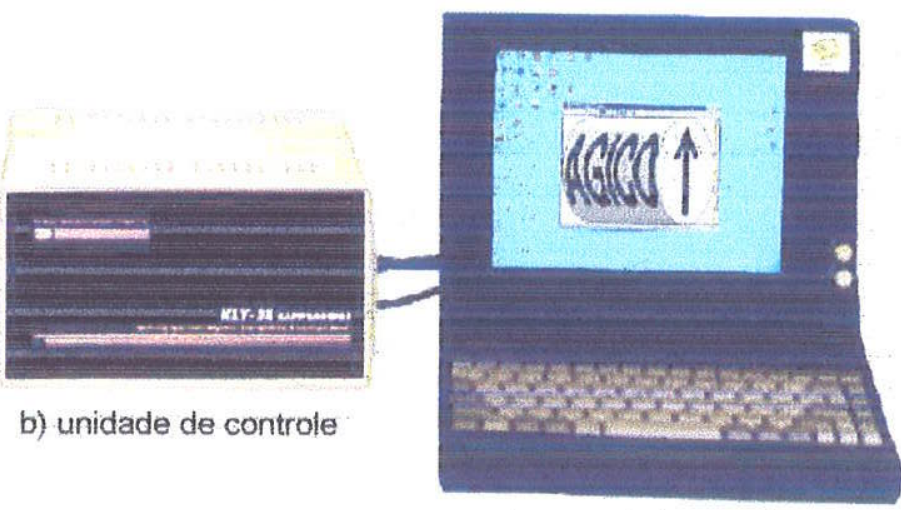

c) computador e sofitwares

Fig. 2.2. Aparelho Kappabridge $\mathrm{KLY}-3 \mathrm{~S}$

a) unidade de medidas; b) unidade de controle; c) computador; d) amostra orientada para análise. 
Cada testemunho de $12 \mathrm{~cm}$ é partido em cilindros no tamanho de $2,2 \mathrm{~cm} \times 2,54 \mathrm{~cm}$ (fig. 2.2.d.), tamanho exigido pelo porta-amostra (fig.2.2.e.) da unidade de medidas do Kappabridge KLY - CS (fig.2.2.a.). As sobras de corte podem ser usadas para análises petrográficas em lâmina delgada, seção polida, raios- $X, M E V$, etc.

As amostras cilíndricas obtidas a partir do corte dos testemunhos são remarcadas, seguindo a marcação original de orientação do furo, em cada cilindro e estas marcações são as guias para colocação do cilindro no porta-amostra do Kappabridge. Após esta remarcação as amostras são envolvidas por uma película de plástico-filme para evitar a contaminação dos aparelhos, durante a análise.

\section{- Equipamentos de medida}

O equipamento usado para medidas de susceptibilidade magnética média, total e da anisotropia de susceptibilidade magnética é o susceptibilímetro Kappabridge, KLY - 3S.

Este aparelho consiste de uma unidade coletora de medidas, uma unidade de controle do equipamento e um computador acoplado (figs. 2.2.a.; 2.2.b.; 2.2.c.), que usa softwares gerenciador, processador de cálculos e de plotagem.

O aparelho gera um campo de indutor de alta precisão e está equipado com sistema automático de calibragem e compensação de variações térmicas.

Este aparelho mede a susceptibilidade magnética de uma amostra cilíndrica em 3 posições perpendiculares. Durante cada série de medidas, a amostra é rotacionada espacialmente de modo que 15 medidas de susceptibilidade são obtidas em torno da amostra (fig.2.3.).

Estas medidas geram tensores de susceptibilidade, cujos valores são medidos em solenóides compensados de sexta ordem, com alto campo de homogeneidade, localizados no interior da unidade de medidas.

A medição é rápida, cerca de 2 min por amostra. A precisão das medidas é gerada por controle e ajuste interno automático de fatores como o erro estatístico, compensação das medidas pelas médias e compensação do background de susceptibilidade total.

Os dados são gerados em formato de arquivo padrão run e formato raw e transferidos digitalmente, direto da unidade de medidas para o computador, através da unidade de controle.

A parte digital do equipamento é baseada em componentes micro-eletrônicos e o microprocessador da unidade de controle gerencia totalmente as funções do KLY- 3S, que não possui nenhum botão de controle manual para o processamento dos dados (fig. 2.2.b.). 

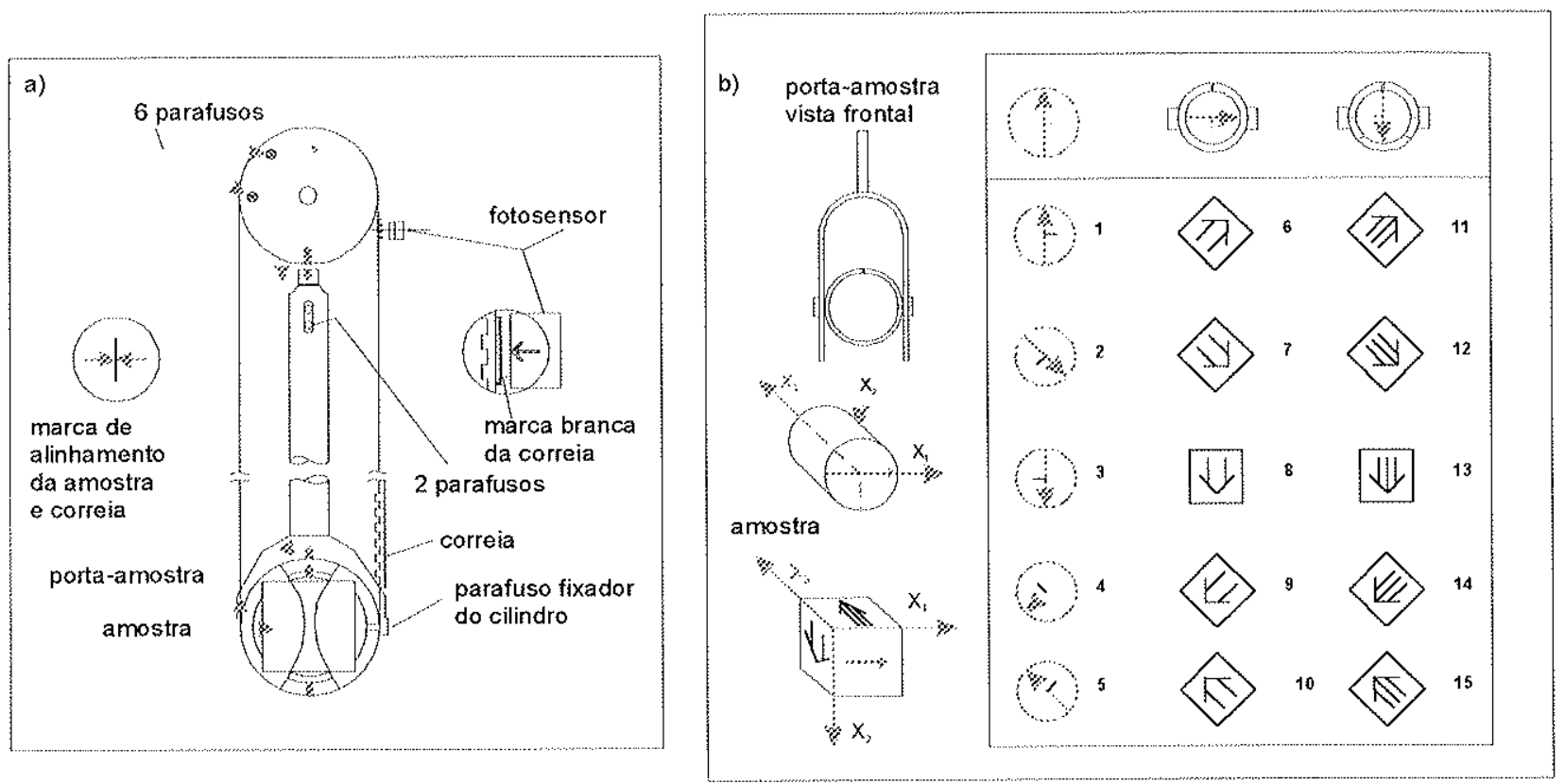

Fig.2.3. Esquema do posicionamento de amostras para análise no KLY - 3S.

a) Desenho esquemático frontal da parte superior do $K L Y-3 S$ que rotaciona as amostras, evidenciando o porta-amostra, sistema de correias e marcas de alinhamento. N.B.: a seta que orienta a amostra deve estar perfeitamente alinhada com a marca existente no porta-amostra, caso contrário serão gerados dados bipolares, sem significado geológico.

b) Amostra cilíndrica, marcada segundo a orientação do furo e conforme os eixos da própria amostra $\left(x_{1}, x_{2}, x_{3}\right)$ é colocada e fixada manualmente no porta-amostras do susceptibilímetro (vista frontal, simplificada), primeiro alinhando $x_{1}$ com a marca existente no porta-amostras, quando é obtido um conjunto de medidas, depois alinhando $x_{2}$ e finalmente $x_{3}$; durante cada série de medidas, a amostra é rotacionada em 15 posições (desenhos de 1 a 15 ), que fornecem as medidas de susceptibilidade do material.

\section{- Especificações técnicas do KLY-3S / KLY-3}

Venda e suporte técnico dos equipamentos : AGICO, Co.; Freqüência de Operação: $875 \mathrm{~Hz}$; Intensidade do Campo: $300 \mathrm{~A} / \mathrm{m}$; Homogeneidade do Campo: 0.2 \%; Medida Média Automática: acima de 0,1 (SI); Sensitividade (típica): susceptibilidade total $=2.5 \times 10^{-8}$ $(\mathrm{SI})$, anisotropia $=1.2 \times 10^{-8}(\mathrm{SI})$; Precisão entre as médias: $\pm 0.1 \%$; Calibragem de Precisão Absoluta: $\pm 3 \%$; Diâmetro do tubo interior do aparelho : $43 \mathrm{~mm}$; Voltagem: $100-240 \mathrm{~V}, 50 / 60$ $\mathrm{Hz}$; Temperatura média de Operação: $+15^{\circ} \mathrm{C}$ até $+35^{\circ} \mathrm{C}$; Umidade relativa do ar máxima: 80\%; Dimensões e peso: unidade de gerenciamento: $260 \times 160 \times 250 \mathrm{~mm} / 4 \mathrm{~kg}$, unidade coletora: $240 \times 320 \times 330 \mathrm{~mm} / 11 \mathrm{~kg}$.

\section{- Softwares usados para ASM}

O processo de obtenção das atitudes (azimute e mergulho) e valores dos eixos do 
elipsóide de ASM, da susceptibilidade média, de alguns parâmetros de forma de elipsóide de ASM, valores de confiança das medidas e outros dados de cada cilindro é gerenciado por um pacote de softwares associado ao sistema.

A planilha de dados resultante no final das medidas é obtida por este pacote de softwares, que é fornecido com o aparelho Kappabridge pela AGICO.Co.

O SUSAR é o software gerenciador e determina a ASM de rochas usando o KLY 3S. O ANISOFT é o pacote de softwares que processa os dados de anisotropia obtidos no Kappabridge e transforma estes dados em coordenadas esféricas, permitindo a plotagem em estereogramas de rede equiárea para estudos.

O aparelho é calibrado, após o que o cilindro é colocado na unidade de medidas. A partir destas medidas, um valor de susceptibilidade total é medido e o tensor de susceptibilidade completo é calculado. Os erros estatísticos na determinação deste tensor são estimados usando um método baseado em princípios de estatística multivariante.

Os dados medidos, como o valor dos autovetores $\mathrm{K} 1$, $\mathrm{K} 2$ e K3, os parâmetros derivados do tensor de susceptibilidade, as orientações médias das direções principais de anisotropia e susceptibilidade e as orientações geográficas de $K 1, K 2$ e $K 3$, são apresentados na tela e podem ser gravados em disquete.

\subsubsection{Susceptibilidade magnética e ASM}

Susceptibilidade magnética $(K=M / H)$ é a relação entre o campo magnético aplicado (H) a um material e a magnetização $(M)$ adquirida por este material devido à aplicação deste campo.

Ké um escalar para corpos isotrópicos. Para corpos anisotrópicos, $\mathrm{K}$ é um tensor simétrico de segunda ordem que relaciona a intensidade do campo aplicado com a magnetização adquirida $M_{i}=K_{i j} H_{j}$, sendo ij as direções ortogonais $1,2,3$. As direções e as intensidades dos vetores $\mathrm{K}_{\mathrm{ij}}$ definem os principais eixos de susceptibilidade magnética.

Tanto $\mathrm{M}$ quanto $\mathrm{H}$ são expressos em Ampères por metro para a susceptibilidade volumétrica, usada neste trabalho.

As medidas de $\mathrm{K}$ são feitas em temperatura ambiente e sob baixo campo magnético indutor ( $<1 \mathrm{mT}$ ). K é adimensional e expressa em unidades 'Sl'.

Em geral, a susceptibilidade magnética varia de acordo com os valores do campo magnético aplicado e da temperatura aos quais é submetido um determinado material e também de acordo com as direções em que se mede a susceptibilidade magnética desse material, resultando em não-paralelismo dos vetores $\mathrm{H}$ e $\mathrm{M}$. 


\subsubsection{Caracterização do elipsóide de susceptibilidade magnética}

A susceptibilidade média $(\mathrm{Km})$ de uma amostra é expressa pela relação $(\mathrm{K} 1+\mathrm{K} 2$ + K3) / 3, onde K1, K2 e K3 correspondem às susceptibilidades máxima, intermediária e mínima da amostra, expressas em unidades SI (Nagata, 1961, Janak, 1965, apud Tarling \& Hrouda, 1993) e seus valores representam os eixos do elipsóide de susceptibilidade (fig.2.4.).

\section{K3}

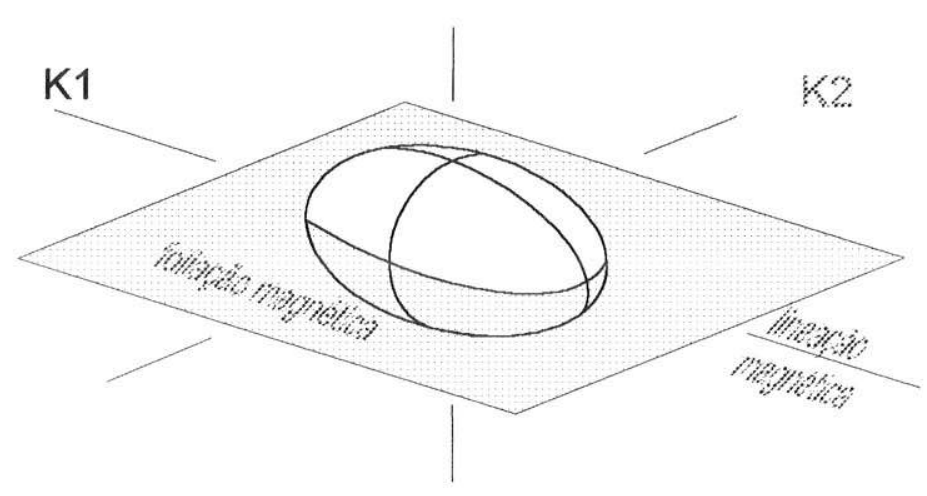

Fig.2.4. Elipsóide de susceptibilidade magnética.

K1 = eixo cujo valor escalar representa a susceptibilidade máxima (Kmax) e cuja atitude geográfica representa a lineação magnética; K2 = eixo cujo valor escalar representa a susceptibilidade intermediária (Kint); K3 = eixo cujo valor escalar representa a susceptibilidade mínima (Kmin) e cuja atitude geográfica representa o pólo da foliação magnética.

A ASM é expressa através deste elipsóide pela comparação dos valores de susceptibilidade ao longo dos três eixos ortogonais K1, K2 e K3. Se estes eixos são iguais, o elipsóide é esférico, portanto não há anisotropia. Se K1>K2 $\approx 3$, o elipsóide é prolato, e a anisotropia está contida no plano que contém K1 e K2. Se K1 $\approx$ K2 e K2>K3, o elipsóide é oblato e a anisotropia está contida no plano que contém K2 e K3.

O elipsóide de susceptibilidade magnética é caracterizado por parâmetros que podem ser definidos a partir dos eixos de susceptibilidade magnética e, alguns destes parâmetros definem a fábrica magnética da rocha, como a anisotropia total $(P)$, a anisotropia linear ou lineação $(L)$ e a anisotropia planar ou foliação $(F)$.

Os elipsóides podem ser interpretados como indicadores do alinhamento estatístico de grãos magnéticos alongados ou achatados. A susceptibilidade magnética média de uma rocha é devida à contribuição das susceptibilidades dos minerais ferromagnéticos e paramagnéticos, e sua anisotropia descreve a fábrica magnética desta rocha (Bouchez, 2000).

A forma deste elipsóide pode ser representada por uma gráfico de $L$ em função de $F$ 
que equivale ao diagrama de Flinn. Neste diagrama, $\mathrm{K}_{\mathrm{Flinn}}=(\mathrm{L}-1) /(\mathrm{F}-1)$, onde $0 \leq \mathrm{K}_{\mathrm{Flinn}}<1$ para os elipsóides oblatos e $\mathrm{K}_{\text {Flinn }}>1$ para os elipsóides prolatos.

Outra maneira de obter a forma do elipsóide de ASM é a plotagem do parâmetro T (de Jelinek) das amostras em estudo, onde $T \in[-1+1], 0<T \leq 1$ para elipsóides oblatos e $0>T \geq 1$ para elipsóides prolatos.

O parâmetro de forma do elipsóide (T) plotado em função do grau de anisotropia (P) das amostras fornece a forma do elipsóide e também a visualização de quanto deformado este elipsóide se apresenta. Nesta plotagem, valores de T entre 0 e 1 caracterizam elipsóides oblatos e valores de T entre 0 e -1 caracterizam elipsóides prolatos. $\mathrm{O}$ grau de anisotropia é visualizado pela posição da amostra no eixo de plotagem de $\mathrm{P}$ e podemos também verificar quão anisotrópicos são os elipsóides de cada campo.

\subsubsection{Anisotropia magneto-cristalina e anisotropia de forma}

Hrouda (1982), Borradaile (1988) e Hargraves et al. (1991) colocam que a anisotropia de forma e a anisotropia magnetocristalina são os mecanismos principais determinantes e representantes da fábrica magnética de uma rocha.

Os estudos sobre a aplicabilidade da ASM em estudos de petrofábrica colocam que esta é conseqüência do alinhamento preferencial dos minerais ferromagnéticos segundo a sua forma - anisotropia de forma, ou segundo a orientação de suas redes cristalinas anisotropia magnetocristalina.

A petrofábrica de uma rocha pode ser caracterizada através da orientação planar e/ou linear dos seus componentes minerais, cujas atitudes são tomadas no campo e podem ser verificadas por análise microestrutural, sendo que esta petrofábrica pode ser comparada com a petrofábrica magnética (fig. 2.5.).

Nesta figura temos blocos diagrama esquemáticos da petrofábrica de rochas com orientação preferencial dos minerais tabulares (micas e hematita) e prismáticos (anfibólios) nas colunas à esquerda, representando a anisotropia magnetocristalina. Na coluna da direita temos a fábrica da magnetita, representando a anisotropia de forma.

Na fábrica planar, o alinhamento dos minerais ocorre normal à K3, no plano K1-K2, o elipsóide é oblato, a foliação predomina sobre a lineação. Na fábrica linear, o alinhamento dos minerais ocorre paralelo ao plano $\mathrm{K} 1-\mathrm{K} 2$, com o eixo longo dos minerais segundo a direção de K1, o elipsóide é prolato, a lineação predomina sobre a foliação.

A magnetita (polidomínio) apresenta anisotropia de forma, e seu eixo longo (de fácil magnetização) é paralelo à K1 na fábrica linear, o elipsóide é prolato. Na fábrica planar ocorre achatamento normal à K3, o elipsóide é oblato (fig.2.5.). 


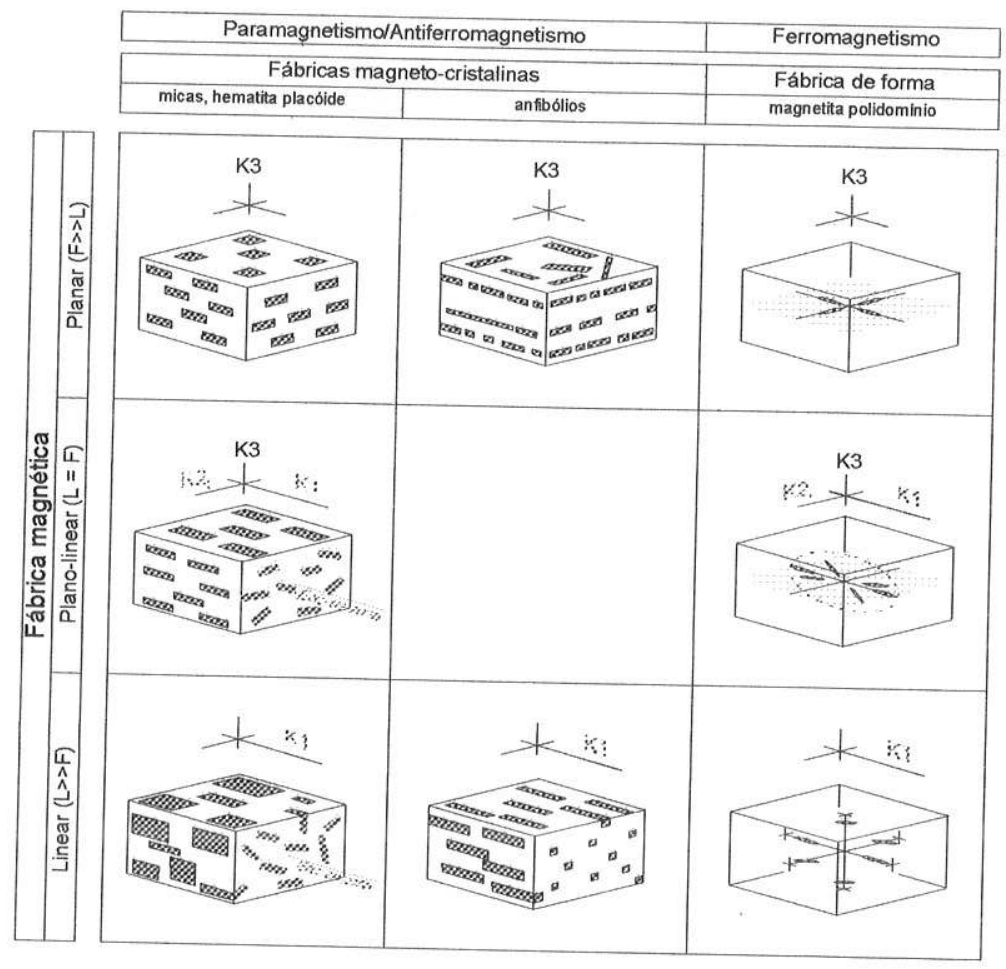

Fig.2.5. Anisotropia da fábrica magnética em relação à petrofábrica dos principais minerais magnéticos de rochas de composição granítica (fig.extraída de Archanjo, 1993).

$\mathrm{K} 1, \mathrm{~K} 2$ e K3 são os eixos de susceptibilidade magnética dos minerais. $\mathrm{K} 1 \geq \mathrm{K} 2 \geq \mathrm{K} 3$. (vide texto acima)

A possibilidade de correlação entre a petrofábrica e a fábrica magnética das rochas permite associações estruturais que caracterizam marcadores cinemáticos e permitem análise estrutural através de dados de fábrica magnética.

Em rochas aparentemente isotrópicas, como as rochas granulíticas aflorantes na área desta dissertação, a medida das estruturas planares e/ou lineares em campo é difícil, tornando a ASM uma ferramenta relevante para o estudo da cinemática da área, que foi favorecido pela obtenção das relações entre a fábrica magnética dos minerais, suas anisotropias e pela possibilidade de obter direções de foliação e lineação magnética onde os equivalentes eram escassos ou inexistentes.

\subsubsection{Parâmetros de Anisotropia Magnética}

No estudo da ASM podem ser usados vários parâmetros(Jelinek, 1981; Hrouda, 1982) de acordo com a natureza da informação desejada, que podem ser definidos a partir dos eixos de susceptibilidade magnética e caracterizam o elipsóide de susceptibilidade magnética (Elwood et al., 1988).

As diferenças entre os parâmetros derivam dos métodos de medida e cálculo destes 
parâmetros. Susceptibilímetros medem diretamente os elementos do elipsóide de susceptibilidade total e fornecem diretamente os parâmetros baseados nas razões entre as magnitudes, enquanto os parâmetros baseados nas diferenças precisam ser calculados (Elwood et al., 1988).

Os principais parâmetros de anisotropia em uso estão baseados nas razões entre as susceptibilidades principais, como o grau de anisotropia $\mathrm{P}$, nas diferenças entre as susceptibilidades, como a anisotropia total $\mathrm{H}$ e na combinação entre as razões e diferenças das susceptibilidades principais, como a porcentagem de anisotropia $\mathrm{H}$.

A fábrica magnética de uma rocha é definida pelos parâmetros $P=K 1 / K 3$ (grau de anisotropia total), L=K1/K2 (anisotropia linear ou lineação magnética) e $F=K 2 / K 3$ (anisotropia planar ou foliação magnética).

Os parâmetros utilizados nesta dissertação estão caracterizados abaixo e uma vez definidos, conforme recomendado na literatura (Elwood et al., op.. cit;; refs. in Tarling \&Hrouda, 1993) serão utilizados nas tabelas, gráficos e texto através de suas notações.

$\mathrm{K}_{\mathrm{m}}=(\mathrm{K} 1+\mathrm{K} 2+\mathrm{K} 3) / 3$, susceptibilidade magnética média;

$\mathrm{P}=\mathrm{K} 1$ / K3, grau de anisotropia (Nagata, 1961);

$P^{\prime}=\exp \left\{2\left[\left(n 1-n_{m}\right)^{2}+\left(n 2-n_{m}\right)^{2}+\left(n 3-n_{m}\right)^{2}\right]\right\}^{1 / 2}$, grau de anisotropia corrigido (Jelinek, 1981);

$H=(K 1-K 3) / K 2 \times 100$, grau ou porcentagem de anisotropia (Howell et al., 1958);

$\mathrm{L}=\mathrm{K} 1 / \mathrm{K} 2$, anisotropia linear ou lineação magnética (Balsley \& Buddington, 1960);

$\mathrm{F}=\mathrm{K} 2$ / K3, anisotropia planar ou foliação magnética (Stacey et al., 1960);

$\mathrm{T}=(2 \ln \mathrm{K} 2-\ln \mathrm{K} 1-\ln \mathrm{K} 3) /(\ln \mathrm{K} 1-\ln \mathrm{K} 3)$, parâmetro de forma do elipsóide (Jelinek, 1981).

Os parâmetros grau de anisotropia $\mathbf{P}$, grau de anisotropia corrigido $\mathbf{P}^{\prime}$ e grau ou porcentagem de anisotropia $\mathbf{H}$ são equivalentes, com diferenças a partir da segunda ou terceira casa decimal.

Foram elaborados gráficos de TxP' para cada afloramento analisado permitindo considerações sobre o tipo de elipsóide presente em nível de amostra, portanto, com controle petrográfico e, quando possível, estrutural de campo.

Nos gráficos de TxP' os elipsóides oblatos plotam valores de T positivos, próximos a +1 enquanto elipsóides prolatos plotam valores negativos, aproximados a -1 e elipsóides neutros (triaxiais) plotam com valores de $\mathrm{T}$ próximos à zero.

A plotagem do parâmetro $L$ (ordenada) em função de $F$ (abcissa) é similar a plotagem da lineação contra a foliação, ou plotagem tipo Flinn (Hrouda \& Janak, 1976) onde a fábrica que apresenta elipsóides oblatos plota abaixo da inclinação do gradiente unitário e a fábrica com elipsóides prolatos plota acima desta linha. 
A comparação da plotagem dos parâmetros $P, P^{\prime}$ e $T$ em gráficos separados representando áreas com mesmas amostras possibilita a verificação da variação da forma associada a variação do grau de anisotropia do elipsóide, refletindo a anisotropia da fábrica para as amostras destas áreas e o grau de deformação do elipsóide.

A plotagem das foliações e lineações magnéticas em mapa estrutural fornece importantes informações referentes aos domínios estruturais presentes na área analisada e permitem comparações com o mapa estrutural de marcadores obtidos em campo.

O primeiro passo na interpretação da ASM é a verificação se os eixos magnéticos são coerentes com os eixos da petrofábrica esperada.

Entretanto, se esta verificação fosse sempre possível para ambos os elementos da petrofábrica (lineação e foliação), as justificativas para o uso da ASM como técnica auxiliar de obtenção desta petrofábrica seriam bastante reduzidas. Frequentemente a foliação pode ser obtida por meios convencionais e utilizamos a ASM para obter a lineação.

Simplificando, se K3 é normal à direção da foliação observada num dado ponto, podemos usar K1 como medida da lineação.

Rochette et al. (1999) realizou estudos sobre a relação usual entre ASM e a petrofábrica. A fábrica magnética dita "normal" corresponde à situação onde K1 é paralelo à lineação estrutural, caracterizando a fábrica linear e K3 é perpendicular à foliação estrutural, caracterizando a fábrica planar. Neste caso, a simetria do elipsóide de ASM reflete a simetria da petrofábrica (e.g. $\mathrm{L}<<F$ para petrofábrica planar). Em alguns casos, os eixos K1 e K3 estão invertidos, caracterizando fábrica magnética inversa e em outros casos os eixos K1, K2 e K3 estão trocados, caracterizando fábrica intermediária.

Segundo estes autores, fábricas magnéticas "anormais" ou reversas podem ocorrer em rochas afetadas por deformação intensa, em rochas com petrofábrica sob efeito de minerais paramagnéticos, magnetita simples-domínio ou óxidos e sulfetos secundários.

Conforme a correlação verificada entre a petrofábrica e a fábrica magnética, as amostras analisadas no presente trabalho apresentaram fábricas magnéticas normais, permitindo o uso direto de K1 representando a lineação e K3 o pólo do plano de foliação magnéticas.

\subsubsection{Magnetismo e caracterização da mineralogia magnética}

O campo magnético da Terra provoca um campo secundário induzido nas rochas que contém minerais magnéticos, com intensidade proporcional à intensidade do campo geomagnético, onde a constante de proporcionalidade é a susceptibilidade magnética da rocha. O alinhamento de um cristal alongado suspenso de magnetita (magnetização, M) 
conforme a direção dos pólos norte e sul da Terra (campo magnético, H) são relacionados por uma constante de proporcionalidade (susceptibilidade magnética, K) e esta relação é o princípio da bússola e um dos fundamentos do estudo de magnetismo de rochas.

A caracterização da mineralogia magnética das rochas pode ser feita através de métodos magnéticos e/ou convencionais variados $e$, neste trabalho foi usada a microscopia com luz refletida, em seções polidas.

Os minerais apresentam diferentes comportamentos magnéticos, que podem ser visualizados no gráfico que relaciona o campo magnético induzido $(H)$ com a magnetização (M) (fig. 2.6.).

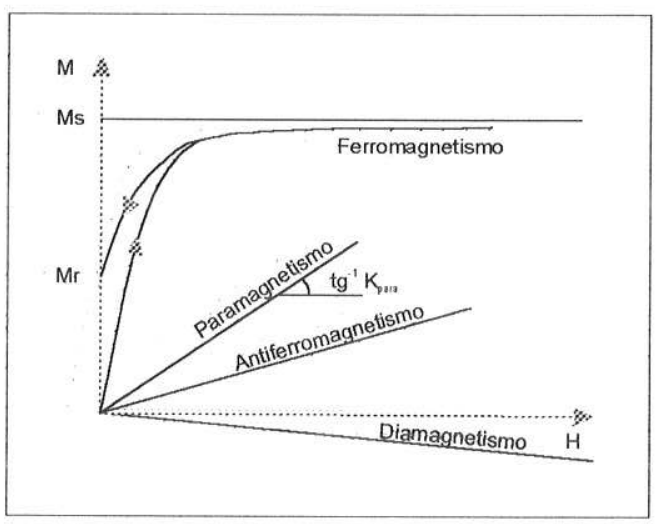

Fig.2.6. Comportamentos magnéticos conforme a relação $M / H$.

A susceptibilidade magnética $(K)$ varia em função dos diferentes comportamentos magnéticos. $A$ declividade das retas define o valor de $\mathrm{K}$ para os minerais paramagnéticos, antiferromagnéticos e diamagnéticos. $\mathrm{K}$ : razão entre $\mathrm{M}$ (magnetização) e $\mathrm{H}$ (campo magnético induzido)

Para os minerais ferromagnéticos: Ms: magnetização de saturação, o ferromagnetismo mostra susceptibilidade fortemente positiva em campo fraco mas que se anula em campo forte devido à Ms; Mr: magnetização remanescente, os minerais ferromagnéticos apresentam uma imantação residual ou remanescente, mesmo sob campo indutor nulo. (figura extraída de Dunlop et al., 1997)

Os minerais ferromagnéticos possuem susceptibilidades magnéticas até $1 \times 10^{6}$ vezes maiores que os diamagnéticos e paramagnéticos.

Como visto na figura acima, a susceptibilidade magnética $(K)$ varia conforme os tipos de comportamento magnético: o ferromagnetismo, o paramagnetismo, o antiferromagnetismo e o diamagnetismo.

\section{- Diamagnetismo}

Em todos os materiais, o campo magnético aplicado resulta na alteração das órbitas eletrônicas, gerando um momento magnético oposto ao campo indutor aplicado.

Este efeito negativo é o diamagnetismo e esta forma de magnetização ocorre em todos os materiais. 
A susceptibilidade diamagnética pode ser cancelada por dois efeitos positivos maiores em algumas substâncias, o paramagnetismo e o ferromagnetismo.

O diamagnetismo existe somente na presença de um campo magnético externo aplicado e independe de temperatura, possuindo valor de susceptibilidade magnética negativo. A susceptibilidade diamagnética é da ordem de $10^{-5} \mathrm{SI}$ ou inferior. O feldspato, grafite e quartzo são minerais diamagnéticos.

\section{- Paramagnetismo}

O paramagnetismo é o efeito produzido pelo alinhamento dos dipolos atômicos com o campo magnético externo aplicado. Como exemplos de minerais paramagnéticos temos biotita, muscovita, anfibólio e piroxênio.

\section{- Ferromagnetismo}

O ferro e outros elementos ferromagnéticos e.g. cobalto, níquel e manganês, com fracas magnetizações permanentes, se tornam fortemente magnetizados quando expostos a um campo magnético.

O ferromagnetismo é o magnetismo que ocorre em substâncias onde os spins eletrônicos estão emparelhados por forças de interação ou superinteração quânticas, com todos os vetores dos spins eletrônicos na mesma direção em cada unidade elementar de volume (Collinson, 1982; Jacobs, 1989).

Há três tipos de ferromagnetismo:

- ferromagnetismo s.s., onde os materiais ferromagnéticos adquirem magnetização espontânea muito forte, de mesma direção e sentido, e.g. ferro, cobalto, níquel e manganês;

- ferrimagnetismo, onde um dos dois retículos magnéticos antiparalelos é maior que o outro, causando uma magnetização remanescente mesmo na ausência de campo magnético externo. Neste caso o momento magnético resultante é diferente de zero quando o campo magnético externo é nulo, e.g. magnetita, pirrotita, hematita (fraco).

- antiferromagnetismo, onde o retículo magnético do material é magnetizado em direções exatamente iguais e sentidos opostos, ou seja, os momentos magnéticos resultantes dos subdomínios paralelos e antiparalelos se cancelam.

A susceptibilidade magnética resultante é pequena, da ordem das substâncias paramagnéticas, e.g. ilmenita. 


\subsubsection{Minerais magnéticos}

Minerais magnéticos são os minerais que conservam uma magnetização remanescente $M_{R}$, depois de afetados por um campo magnético, natural ou artificial.

$O$ estudo dos minerais que conservam magnetização remanescente natural e a origem desta magnetização são relevantes para o estudo do paleomagnetismo e também para estudos de geologia estrutural, análise cinemática e evolução geotectônica.

O conteúdo de minerais magnéticos das rochas varia de 0,3 a $1 \%$ e causam diferentes respostas quanto ao comportamento magnético, de acordo com ocorrência como minerais primários ou secundários, variações na granulometria, presença de soluções sólidas, como magnetita, ilmenita e hematita (fig.3.1.e.14.) ou pela presença de impurezas em sua estrutura.

Os métodos para identificação e caracterização de minerais magnéticos são a microscopia ótica de luz refletida, a difratometria de raios-X, a microscopia eletrônica de varredura, a espectroscopia Mössbauer e métodos magnéticos, como a análise das temperaturas de Curie (temperatura na qual as vibrações térmicas impedem o emparelhamento quântico entre os elétrons, eliminando o ferromagnetismo).

Para estudo destes minerais magnéticos foram desenvolvidas várias técnicas como a NRM (magnetização remanescente natural), a PTRM (magnetização termo-remanescente parcial), a ARM (magnetização remanescente anisterética) e a ASM (anisotropia de susceptibilidade magnética).

Instrumentos como balanças de Faraday, magnetômetros de vibração e giro e susceptibilímetros medem a magnetização e/ou a susceptibilidade com alta precisão, pois os minerais magnéticos ocorrem em quantidade pequena em relação ao volume total da rocha.

\subsubsection{Caracterização dos minerais magnéticos identificados}

- Magnetita $\left(\mathrm{Fe}_{3} \mathrm{O}_{4}\right)\left(\mathrm{Fe}^{+2} \mathrm{Fe}_{2}{ }^{+3} \mathrm{O}_{4}\right) \quad$ (Prancha 5, fot.24.; fot.26.)

A magnetita é o principal mineral responsável pelo magnetismo nas rochas; pertence ao grupo dos espinélios, que são óxidos cristalizados segundo o sistema cúbico, compondo uma série normal e outra inversa em função da distribuição dos elementos químicos nos seus sítios cristalinos (Waychunas, 1991; Dunlop et al., 1997), (fig.2.7.). 


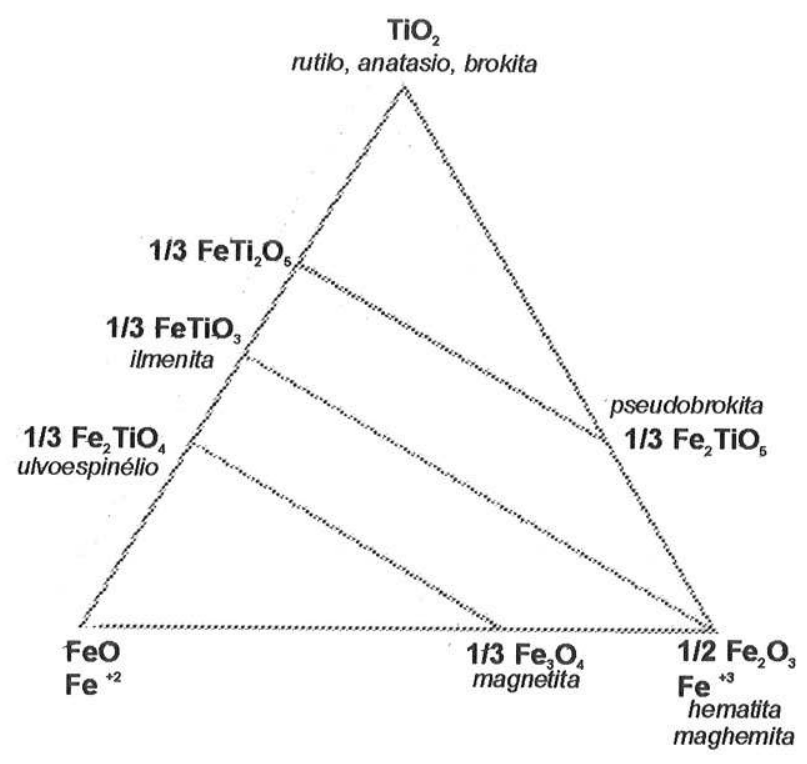

Fig. 2.7. Diagrama de fases do grupo dos espinélios.

(modificado de Dunlop et al., 1997)

A magnetita, em seção polida, tem cor cinza clara, ou cinza castanho-claro, é isótropa com nicóis cruzados e possui T Curie: $578^{\circ} \mathrm{C}$ (Collinson, 1983; Peckett, 1992).

Este mineral possui certas direções cristalográficas preferidas pela magnetização de saturação, chamadas de eixos de fácil magnetização, ao longo de <111> e outras de difícil magnetização, ao longo de <100> (fig.2.8.), devido à diferença da energia potencial magnética requerida para estabelecer um campo $\mathrm{H}$ com magnetização $\mathrm{M}$ ( $\mathrm{M}$ média de todos os domínios). Esta ddp magnética consiste na medida da anisotropia magnetocristalina do mineral (Dunlop et al., 1997).

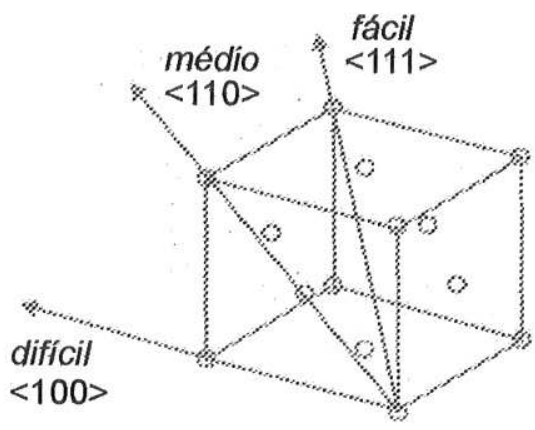

Fig. 2.8. Parte da cela unitária da magnetita com eixos preferenciais de magnetização. (figura modificada de Dunlop et al., 1997)

É um espinélio inverso com os íons de ferro distribuídos em função da temperatura, pois a magnetita é comumente deficiente em cátions e os sítios vagos causam um desvio 
na sua estequiometria. Os sítios reticulares vazios e os íons intersticiais mudam seu posicionamento com a temperatura, causando deslizamentos intracristalinos (Lagoeiro, 1998, 1998b).

A magnetita tem cela unitária com íons de oxigênio arranjados em empacotamento cúbico compacto com momento magnético intenso, possuindo ferrimagnetismo devido aos momentos atômicos diretamente opostos (Peckett, 1992).

- Hematita $\left(\alpha \mathrm{Fe}_{2} \mathrm{O}_{3}\right)\left(\mathrm{Fe}^{3+}\right)_{2} \mathrm{O}_{3} \quad$ (Prancha 8, fot.37.)

A hematita primária pode se formar a partir de magnetita de alta temperatura, por oxidação, e também pseudomorfa sobre a magnetita (martitização). Ocorre frequentemente em cristais que alternam lamelas de exsolução magnetita-hematita, ou hematita-ilmenita (Lagoeiro, 1998, 1998b).

Em processo secundário a hematita pode se formar como produto de inversão de maghemita, durante um reaquecimento da rocha, ou pela desidratação da goethita e precipitação de cimento ultrafino de hematita em sedimentos porosos ricos em ferro.

A hematita pertence ao grupo dos espinélios, e forma série com a magnetita e com a ilmenita. Cristaliza no sistema trigonal, arranjo hexagonal compacto. Apresenta cores do branco ao azul acinzentado pálido e reflexões internas vermelho-vivo sob luz refletida.

Possui anisotropia magnetocristalina iônica e também dipolar, com sinais contrários. É fracamente ferromagnética, com $\mathrm{T}_{\text {curie }}: 675^{\circ} \mathrm{C}$.

A magnetização remanescente da hematita é fraca se comparada com a da magnetita, mas não é irrelevante. Apresenta a mais alta temperatura de bloqueio remanescente em rochas e pode permanecer aquecendo durante condições metamórficas que ressetariam a remanescência da magnetita (fig.3.20 in Dunlop et al., 1997).

A forma $\gamma \mathrm{Fe}_{2} \mathrm{O}_{3}$, maghemita, possui estrutura do tipo espinélio e não foi identificada neste estudo.

\section{- llmenita $\left(\mathrm{FeTiO}_{3}\right) \quad\left(\mathrm{Fe}^{2+} \mathrm{Ti}^{4+} \mathrm{O}_{3}\right) \quad$ (Prancha 5, fot.25.)}

A ilmenita é um mineral de titânio, fracamente magnético, do grupo dos espinélios, membro final rico em titânio da solução sólida entre hematita e ilmenita. Esta série constitui os equivalentes oxidados dos minerais da série de solução sólida entre ilmenita e maghemita. Estes minerais têm diferentes composições, mas ocupam o mesmo ponto no diagrama ternário, e.g. maghemita (cúbica) e hematita (romboédrica) plotam no mesmo canto inferior direito (fig.2.7.) (Dunlop et al., 1997).

A ilmenita cristaliza no sistema hexagonal, empacotamento hexagonal compacto e, retículo romboédrico centrado. Possui birreflectância branca acinzentada com reflexos 
castanhos e pleocroísmo de reflexão claro, o que a distingue da magnetita. Quando comparada diretamente com hematita, a ilmenita mostra pleocroísmo branco a castanhoclaro (Peckett, 1992).

A ilmenita é antiferromagnética devido ao vazio em seu centro de simetria gerado por substituição de íons de ferro trivalente por combinações de íons de $\mathrm{Fe}^{+2} \mathrm{e} \mathrm{Ti}^{+4}$ (Banerjee, 1991).

A ilmenita e a hematita formam solução sólida completa em $1.050^{\circ} \mathrm{C} \mathrm{e}$, conforme a temperatura decresce a miscibilidade diminui, até a exsolução em $\approx 950^{\circ} \mathrm{C}$.

A oxidação da ilmenita pode ocorrer em três estágios sucessivos, desde ilmenita com manchas de alteração, óxido de titânio e ferro amorfo ao leucoxeno (Dunlop et al., 1997).

- Goethita ( $\alpha$ FeOOH) (Prancha 6, fot.34.)

A goethita é um hidróxido de ferro, cristalizado no sistema ortorrômbico, composto por um empilhamento de camadas de oxigênio e hidroxila em empacotamento compacto, com arranjos internos dos íons de ferro e titânio em sítios octaédricos e tetraédricos.

A goethita ortorrômbica ( $\alpha \mathrm{FeOOH})$ se transforma em romboédrica $\left(\alpha \mathrm{Fe}_{2} \mathrm{O}_{3}\right)$ pela remoção de camadas de hidroxila e de alguns oxigênios em linhas paralelas a ao eixo c para formar água.

A goethita é antiferromagnética, porém, magnética em chama redutora, possuindo $\mathrm{T}_{\text {Curie }}: 120^{\circ} \mathrm{C}$. Pequenas quantidades de impurezas rebaixam consideravelmente este valor.

A goethita origina a hematita por desidratação, em temperaturas entre 250 e $400^{\circ} \mathrm{C}$, com quem intercresce, ficando superparamagnética, (não conserva magnetização remanescente). Adquire um magnetismo superimposto, bem mais fraco que o da hematita. A forma dos cristais de goethita é preservada, mas cada cristal contém muitos microcristais de hematita.

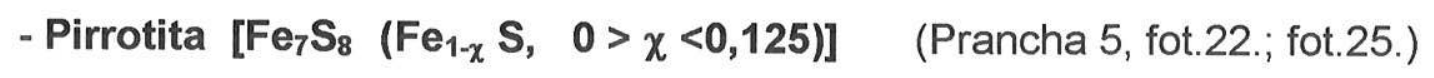

A pirrotita é um sulfeto de ferro cristalizado no sistema. monoclínico, pseudohexagonal, com arranjo prismático trigonal. $\mathrm{T}_{\mathrm{C}}: 320^{\circ} \mathrm{C}$ (Dunlop et al., 1997).

Apresenta, em seção polida, cores de anisotropia cinza-amareladas a cinzacastanhas com vermelho-amarronzado e, reflexos de vermelho-amarronzado, sob luz refletida (Peckett, 1992).

A pirrotita natural é uma mistura de pirrotita hexagonal, antiferromagnética e monoclínica, ferrimagnética, com $M_{R}$ natural maior que a magnetita. 
A pirrotita apresenta comportamento mais próximo ao de uma mistura de fases de $\mathrm{Fe}_{7} \mathrm{~S}_{8}$ que é ferrimagnética com $\mathrm{Fe}_{9} \mathrm{~S}_{10}$ do que como um membro da série da solução sólida que faz com a troilita (FeS), que é antiferromagnética.

Seu ferrimagnetismo advém (semelhante a maghemita) da deficiência de cátions e da ordem dos vazios, o que explica a superestrutura mais simples em altas temperaturas e a maior desordem em baixas temperaturas. Na medida em que aumenta a deficiência em ferro na pirrotita, diminuem os parâmetros da sua rede cristalina (Waychunas, 1991).

O arranjo regular das vacâncias origina uma simetria baixa, com propriedades magnéticas características. A pirrotita tem eixo $\mathrm{c}$ de simetria hexagonal, na direção de difícil magnetização, com os íons de ferro e enxofre confinados em planos c alternados, que formam dois subretículos magnéticos (fig.2.9.).

A pirrotita apresenta magnetização confinada ao eixo c e, o arranjo preferencial dos vazios de um dos subretículos distorce o retículo hexagonal para o monoclínico e confere um momento ferrimagnético intenso em torno de $80 \mathrm{KA} / \mathrm{m}$.

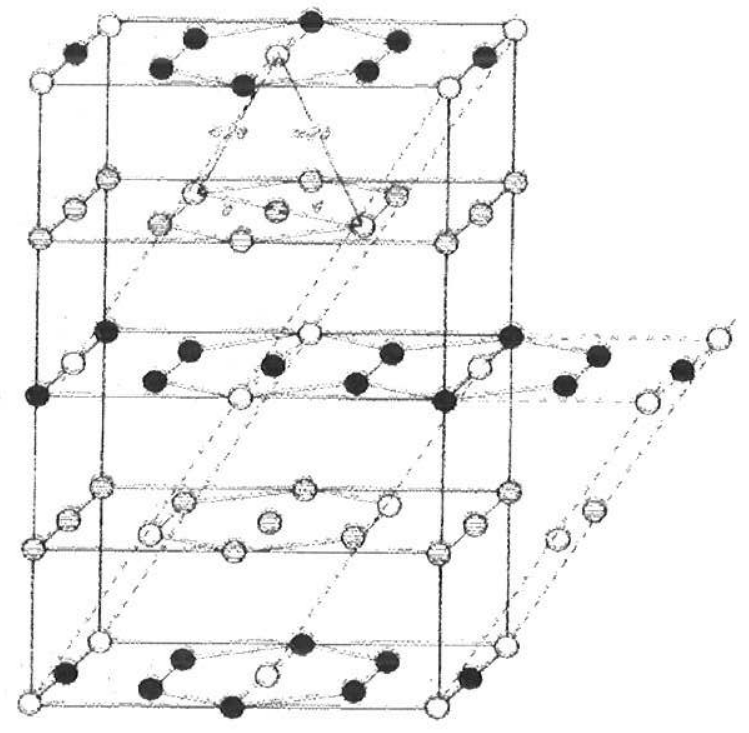

Fig.2.9. Estrutura cristalina e magnética da pirrotita.

Estrutura magnética e distribuição das vacâncias (círculos abertos) e íons de $\mathrm{Fe}^{+2}$ (esferas pretas e hachuradas, de momentos magnéticos opostos) na pirrotita.

A estrutura básica é hexagonal, com subretículos magnéticos correspondendo a planos basais alternados. As vacâncias (vazios) são arranjadas em super-retículos monoclínicos (linhas tracejadas) e estão arranjadas preferencialmente em um dos dois sub-retículos magnéticos, originando o momento ferrimagnético intenso da pirrotita. (extraído de Stacy \& Banerjee, 1974 apud Dunlop, 1997)

A pirrotita hexagonal $\left(\mathrm{Fe}_{9} \mathrm{~S}_{10}\right)$ também é ferromagnética acima da temperatura de transição, diagnóstica da pirrotita hexagonal, $\mathrm{T} \lambda=200^{\circ} \mathrm{C}$. 


\subsubsection{Fábrica magnética}

Os minerais constituem fases com comportamentos magnéticos distintos nas rochas e a magnitude da anisotropia, seja associada com minerais de diamagnéticos, paramagnéticos ou ferromagnéticos, depende de dois fatores principais: a anisotropia intrínseca das partículas e o grau de seu alinhamento.

A anisotropia das partículas individuais abrange dois componentes, que são a anisotropia magnetocristalina e a anisotropia de forma.

A anisotropia magnetocristalina é a tendência de certos minerais à orientação da sua rede cristalina segundo os seus eixos preferenciais de magnetização, os quais coincidem com os eixos de mais fácil magnetização.

A anisotropia de forma consiste no alinhamento dos spins eletrônicos pela ação de um campo magnético indutor, que cria pólos magnéticos norte e sul em pontos opostos da superfície de cada grão (Tarling \& Hrouda, 1993). Ocorre o alinhamento do eixo de fácil magnetização paralelo ao eixo longo do mineral, geralmente em minerais fortemente magnéticos, com susceptibilidade K>1 (Rochette et al., 1999).

As principais diferenças nas respostas anisotrópicas de cada mineral são determinadas por seus respectivos tamanhos de grão (Ruf et al., 1988). Enquanto na anisotropia magnetocristalina dominam os minerais paramagnéticos (hematita,pirrotita), na anisotropia de forma os minerais ferromagnéticos (magnetita) são os responsáveis pela ASM (Tarling \& Hrouda, 1993, Rochette et al., 1999).

A anisotropia magnética de uma rocha é maximizada se os eixos cristalinos de fácil magnetização coincidem com eixos longos quanto à forma cristalina. Entretanto, métodos analíticos não determinam a porcentagem exata da contribuição das anisotropias magnetocristalina e de forma na anisotropia total da rocha (Tarling \& Hrouda, 1993).

Quanto ao comportamento magnético dos minerais, mesmo uma pequena quantidade de minerais ferromagnéticos (e.g. magnetita, pirrotita) é suficiente para que a fração ferromagnética domine a susceptibilidade total da rocha. Borradaile (1987) demonstrou que na medida que a quantidade de magnetita aumenta, a susceptibilidade e a anisotropia da rocha devida aos silicatos tendem ao valor da magnetita real (fig.2.10.).

\section{- Inclusões de minerais magnéticos em silicatos}

Rochas granulíticas possuem silicatos máficos como ortopiroxênio, clinopiroxênio e anfibólios, sendo este último frequente quando estas rochas são afetadas por processos de retrometamorfismo. Possuem também minerais opacos como magnetita e ilmenita e, 
ocasionalmente sulfetos magnéticos como a pirrotita. Geralmente a magnetita é o mineral responsável pela susceptibilidade da fábrica magnética destas rochas, ainda que na forma de inclusões.

Estudos sobre o efeito de impurezas em silicatos máficos como piroxênios ortorrômbicos e piroxênios monoclínicos de rochas granulíticas mostraram que os eixos cristalinos destes silicatos apresentam fraca correlação com os eixos principais de ASM e também que a susceptibilidade magnética total média destes minerais é fortemente afetada pela presença das inclusões de magnetita (Lagroix \& Borradaile, 2000).

Estes autores verificaram que o ortopiroxênio com inclusões de magnetita mostrou $K_{\max }$ paralelo ao eixo c do cristal, sem orientação preferencial das inclusões no retículo do silicato. No clinopiroxênio, de simetria cristalina menor, as inclusões mostraram os 3 eixos de susceptibilidade inclinados para o eixo b do cristal.

Considerando que as inclusões de magnetita nestes silicatos (orientadas ou não) causaram as diferenças entre o valor esperado e o valor de susceptibilidade encontrado por medidas de ASM e ARM nos cristais de piroxênio estudados, Lagroix \& Borradaile (op. cit.) concluíram ser necessária grande cautela na interpretação da orientação cristalográfica preferencial pela ASM destes silicatos máficos.

Concluíram também que, quando inclusa nos silicatos máficos, a magnetita é a responsável pela fábrica magnética da rocha, mas a orientação de seus eixos de ASM não reflete necessariamente a orientação cristalográfica preferencial encontrada nos cristais de piroxênio e anfibólio, podendo causar fábrica magnética inversa ou intermediária.

\subsubsection{ASM e análise estrutural de rochas metamórficas}

As rochas mostram respostas diferentes em relação à deformação e revelam a anisotropia da fábrica magnética, pois são anisotrópicas em diferentes escalas.

A ASM conserva o registro da deformação mesmo em rochas fracamente magnetizadas e as orientações dos eixos do elipsóide de deformação mostram excelente correlação com as orientações dos eixos do elipsóide de ASM. Existe também uma forte correlação entre a lineação de estiramento mineral (que marca a direção do fluxo em zonas de cisalhamento) e a orientação dos grãos alongados de magnetita, que são rotacionados nesta mesma direção de estiramento (Ruf et al., 1988).

Tarling \& Hrouda (1984) propuseram uma visão do comportamento da anisotropia e da susceptibilidade magnética para rochas sedimentares, ígneas e metamórficas.

Estes autores verificaram que as rochas sedimentares apresentam baixa susceptibilidade $\left(<\left[5 \times 10^{-4}\right] 0,5 \times 10^{-3} \mathrm{SI}\right)$ e baixo grau de anisotropia $(P<1,05)$ e nas rochas 
vulcânicas a susceptibilidade é muito maior $\left(\sim\left[10^{-2}\right] 0,1 \times 10^{-3} \mathrm{SI}\right)$, mas o grau de anisotropia permanece similar $(P<1,05)$.

Para as rochas granitóides a susceptibilidade varia de $\left[1 \times 10^{-5}\right]\left(0,01 \times 10^{-3}\right) \mathrm{SI}$ a $\left[5 \times 10^{-2}\right]$ $\left(0,5 \times 10^{-3}\right) \mathrm{SI}$ e o grau de anisotropia varia de muito baixo a $\mathrm{P}=2$.

Tarling \& Hrouda (op..cit.) verificaram que as rochas metamórficas de baixo grau apresentam baixa susceptibilidade $\left(<\left[4 \times 10^{-4}\right] 0,4 \times 10^{-3} \mathrm{SI}\right)$ e baixa a moderada anisotropia, com $\mathrm{P}$ entre 1,05 e 1,15 e H variando entre 5-15\%).

As rochas metamórficas félsicas apresentam baixas susceptibilidades e baixos valores no grau de anisotropia (Tarling \& Hrouda, op..cit.).

Nas rochas metamórficas máficas como anfibolitos encontraram susceptibilidades variando entre $\left[5 \times 10^{-4}\right] \cdot\left(0,5 \times 10^{-3}\right)$ e $\left[1 \times 10^{-2}\right] \cdot\left(0,1 \times 10^{-3}\right)$ SI enquanto a anisotropia variou de pouco a mais de $100 \%$. A fábrica magnética nos anfibolitos menos anisotrópicos é preferencialmente controlada pela hornblenda e pela magnetita nos fortemente magnetizados e anisotrópicos.

As estruturas mais comuns nas rochas metamórficas são a foliação e a lineação e mesmo as estruturas mais complexas são representadas por estas estruturas, como ocorre nas zonas de cisalhamento (Paterson et al.,1989; Ramsay \& Ruber, 1997).

Considerando a deformação produzida pelo cisalhamento foi observado que, sob deformação progressiva, o eixo mais longo das partículas magnéticas sofre reorientação na direção de estiramento das mesmas, gerando uma anisotropia de forma que reproduz a cinemática que afetou a região (Borradaile, 1988).

As relações entre os elipsóides da fábrica mineral e da fábrica magnética da rocha, obtidas a partir de experiências de laboratório e modelagem numérica, mostram concordância e a validade da sua utilização para caracterizar o comportamento estrutural e cinemático de uma área a partir de estudos de ASM, corroborados por dados estruturais obtidos em campo ou outros métodos auxiliares (Borradaile, 1987, 1988, 1991; Borradaile \& Alford, 1987; Tarling \& Hrouda, 1993).

Borradaile (1987) trabalhou com modelamento experimental de anisotropia de susceptibilidade magnética de rochas constituídas por uma composição mineralógica específica, visando verificar efetivamente a correlação entre ASM e deformação em tectonitos metamórficos.

O modelo de ASM para rochas de Borradaile (op. cit.) pressupõe susceptibilidades máxima, intermediária e mínima coaxiais e perfeitamente alinhadas e, que a rocha modelo é homogênea. A matriz da rocha modelo é composta de plagioclásio, que tem susceptibilidade de $-3 \times 10^{-6} \mathrm{SI} / \mathrm{cm}^{3}$, diamagnético e quase isotrópico.

Os grãos de magnetita usados no modelamento foram separados de rochas 
metamórficas, pois a anisotropia da magnetita é influenciada pela forma do grão e poderiam apresentar anisotropias distintas, conforme derivados de rochas metamórficas ou sedimentares.

Borradaile (op. cit.) caracterizou os efeitos da presença de magnetita na composição média de rochas modelo e construiu um gráfico de $L$ (K1/K3) em função de $F$ (K2/K3) mostrando as variações da forma do elipsóide de susceptibilidade (prolatos ou oblatos) conforme a variação do teor de magnetita comparado ao de outros silicatos (fig.2.10.).

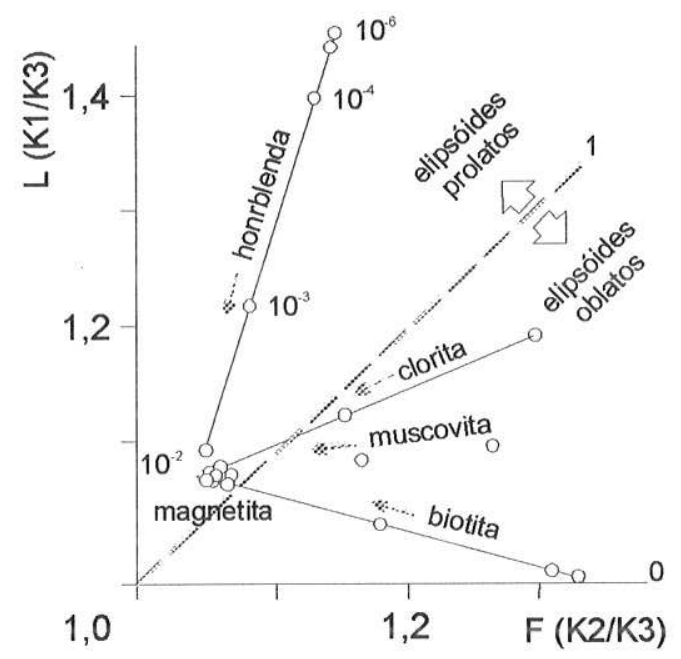

Fig.2.10. Variação dos parâmetros de anisotropia L e F com o teor de magnetita (modificado de Borradaile (1987), apud Archanjo, 1993).

A anisotropia intrínseca da magnetita usada neste modelo é de $L=1,07$ e $F=1,04$.

Neste gráfico, K1, K2 e K3 são as susceptibilidades principais da rocha modelo e cada linha no gráfico corresponde à variação na susceptibilidade de uma rocha em que $40 \%$ de sua susceptibilidade é carregada pelo mineral nomeado na linha.

Os círculos no extremo distal de cada linha indicam a anisotropia na presença de 1 x 10 E-6 \% de magnetita. Os círculos ao longo das linhas indicam os aumentos sucessivos no teor de magnetita (segundo as setas). A maior proporção de magnetita (1\%) plota muito próxima ao ponto onde plota a anisotropia intrínseca da magnetita pura usada neste modelamento.

As mudanças na forma do elipsóide de ASM são substanciais, de oblato a prolato nos casos extremos, de acordo com a variação no teor de magnetita.

No gráfico acima, em cada caso, a forma do elipsóide é determinada pelo silicato magnético. Entretanto, quando a proporção volumétrica de magnetita aumenta, a anisotropia da rocha progressivamente se aproximando ao valor da magnetita escolhido para o estudo, mudando a forma do elipsóide.

Deste estudo, Borradaile (op..cit.) concluiu que a possibilidade de estabelecer a correlação entre a magnitude da deformação finita em rochas metamórficas poliminerálicas e a ASM é feita com dificuldade em tectonitos metamórficos com traços de magnetita, pois esta provoca efeitos que obliteram os efeitos causados pela deformação na orientação da 
forma do elipsóide de ASM.

O tratamento e interpretação das estruturas magnéticas deve considerar que estas podem não representar uma cópia fiel da orientação das estruturas da rocha e a comparação das estruturas magnéticas com os dados estruturais de campo é indispensável para corroboração dos dados.

Aspectos importantes como a mineralogia simples da rocha e a interação entre esta fábrica normal e a fábrica magnética, muito importante no processo de cristalização, devem ser considerados e relevados (Archanjo, 1993) bem como inclusões primárias de minerais magnéticos nos silicatos da rocha e processos secundários de geração de óxidos e sulfetos, pois estes processos promovem respostas que refletem uma superposição das fábricas nos diferentes eventos que afetaram a rocha e podem obliterar a fábrica magnética que responde pelo evento específico em estudo. 


\section{Petrografia e Metamorfismo}

As litologias encontradas na área durante a pesquisa estão descritas petrograficamente e agrupadas pelas similaridades mineralógicas, metamórficas e estruturais dentro do contexto dos Complexos Juiz de Fora (Ebert, 1956, apud Dehler, 1996; Hasui et al. 1981, apud Baptista, 1984; Barbosa \& Grossi Sad, 1983) e Paraíba do Sul (Ebert, 1955, apud Dehler, 1996; Brandalise et al.,1976, apud Brenner et al., 1980). Localmente afloram litologias pertencentes à Suite Intrusiva Espírito Santo (Machado Filho et al., 1983) e ao Gnaisse Eugenópolis (Rosier, 1965, apud Machado Filho et al., 1983; Machado Filho et al., 1983).

Nesta estudo petrográfico foram utilizados os conceitos presentes em Streckeisen (1974, 1975, 1976); Katz (1972); Winkler (1977); Tröger (1979); Philpotts (1989); Peckett (1992); Ramdohr (1980); Ixler (1990) e Craig \& Vaughan (1994).

No presente trabalho, o termo granulito designa as rochas de granulação fina, textura granuloblástica, coloração escura esverdeada, aspecto homogêneo e maciço, portadoras de paragêneses metamórficas inequívocas da fácies granulito, como ortopiroxênio, ou ortopiroxênio + clinopiroxênio + plagioclásio e , o adjetivo granulítico caracteriza a presença de paragênese metamórfica da fácies granulito nas rochas bandadas e/ou com estruturas migmatíticas e miloníticas.

Revisões sobre o tema (Rinne et al.,1949, apud Winge, 1995; Winkler, 1977; Batista, 1984) indicam que rochas granulíticas apresentam recristalização sob condições metamórficas de alta temperatura (acima de $650{ }^{\circ} \mathrm{C}$ ), pressão de $\mathrm{H}_{2} \mathrm{O}$ muito baixa e pressão litostática variável, entre 6 a $10 \mathrm{~Kb}$.

O estudo em campo das relações entre as litologias associado ao estudo petrográfico meso e microscópico das amostras coletadas permitiu caracterizar duas associações litológicas predominantes: a primeira, composta de ortognaisses granulíticos com biotita e hornblenda, granulitos s.s. e charnockitos, pertence ao contexto do Complexo Juiz de Fora e, a segunda unidade, composta de biotita-hornblenda gnaisses com microclínio e granada, metamorfisados na fácies anfibolito, pertence ao Complexo Paraíba do Sul.

Subordinadamente ocorrem biotita-muscovita gnaisses pertencentes ao Gnaisse Eugenópolis e granitóides foliados pertencentes à Suíte Intrusiva Espírito Santo.

Os resultados da análise petrográfica dos litotipos aflorantes na área deste estudo permitiram o esboço de um mapa geológico.

A associação dos dados petrográficos e estruturais obtidos em campo e laboratório com os dados compilados dos trabalhos de Oliveira (1980, 1983), Machado Filho et al. (1983) e Porcher (1997) culminaram no mapa geológico e estrutural da área (Anexo 3). 


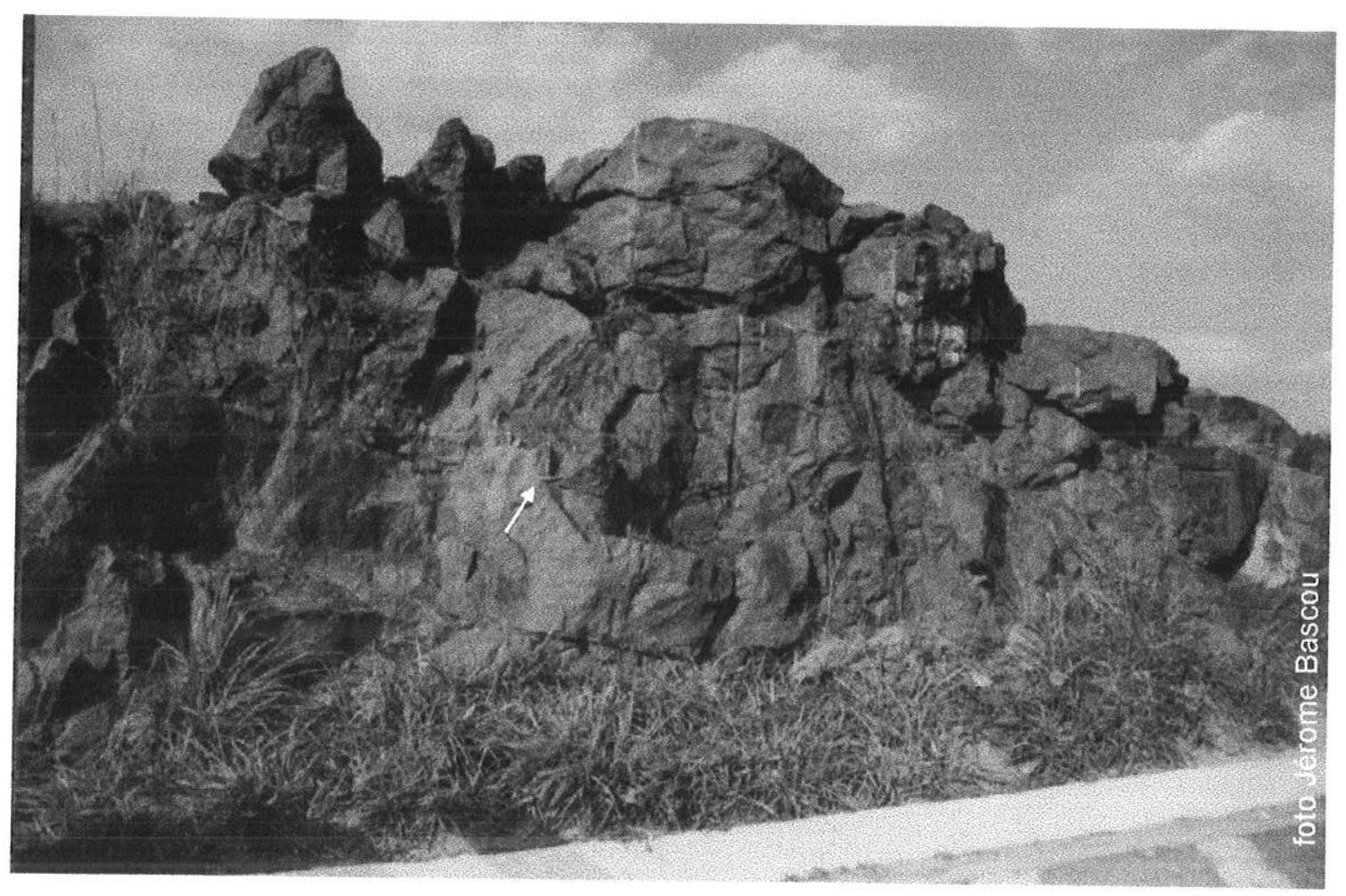

Fot. 1. Biotita - granada gnaisse granulítico (jfkz), Complexo Juiz de Fora. Ponto KJ383, estrada Laranjal - Muriaé.

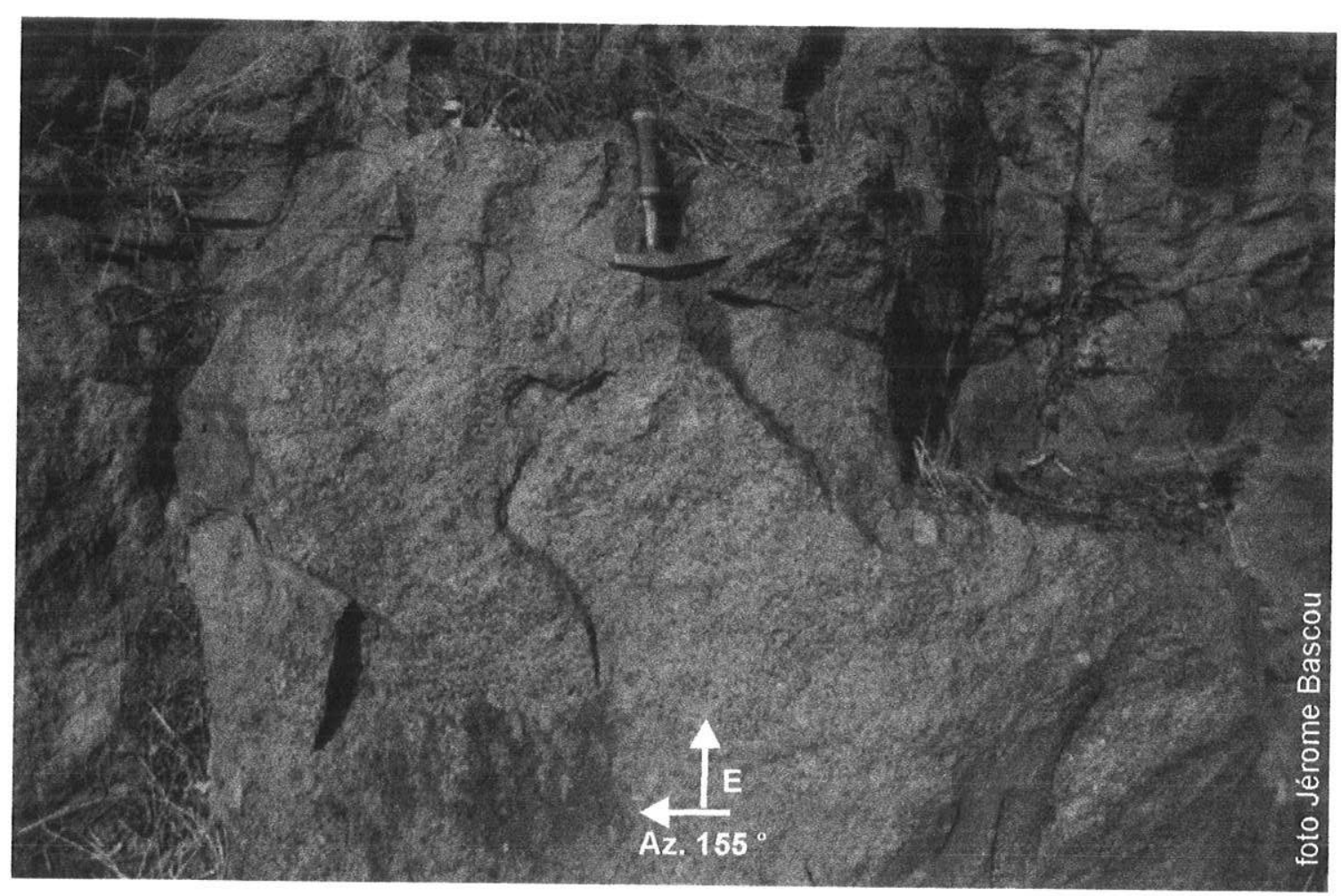

Fot. 2. Biotita - granada gnaisse granulítico (jfkz), Complexo Juiz de Fora. Ponto KJ383, estrada Laranjal - Muriaé. 
Um maior detalhamento da petrografia, petrologia e metamorfismo pode ser obtido em Oliveira $(1980,1983)$ e, sobre as relações entre metamorfismo e deformação, análise microestrutural e estudos geotermobarométricos, em Porcher (1997).

Vários trabalhos abordaram a petrologia, litogeoquímica, condições de metamorfismo e/ou deformação da região que abrange a área deste trabalho e podem ser obtidos através das referências bibliográficas contidas nos trabalhos citados acima e das referências contidas na síntese bibliográfica regional feita neste trabalho (Anexo 1).

\subsection{Complexo Juiz de Fora}

Esta associação litológica engloba granulitos, charnockitos, orto e paragnaisses de composição variada, com paragêneses metamórficas indicativas da fácies granulito

As rochas deste Complexo ocorrem predominantemente nos setores oeste, norte e central, onde afloram granulitos (fot.1.), granada gnaisses granulíticos (fot.2.), gnaisses granulíticos com biotita e hornblenda (fot.3.), biotita granada gnaisses (fot.4.) e charnockitos, dispostos em lentes de orientação preferencial nordeste, intercaladas tectonicamente através de falhamentos de empurrão e transcorrências.

Na porção centro-sul da área, os granada gnaisses granulíticos, gnaisses granulíticos com biotita e hornblenda ocorrem intercalados tectonicamente com os gnaisses milonitizados e gnaisses granatíferos pertencentes ao Complexo Paraíba do Sul.

Na porção central da área, os gnaisses granulíticos estão localmente migmatizados (fot.7.), apresentam enclaves anfibolíticos e aplitos.

Os granulitos (fot.5.) e charnockitos (fot.6.) apresentam aspecto homogêneo e maciço e os gnaisses granulíticos são cinzentos. Os gnaisses granulíticos estão milonitizados na porção sul-sudeste da área, em razão da proximidade com a Zona de Cisalhamento Além Paraíba.

- (jfgg) - granulitos s.s., gnaisses granulíticos enderbíticos, charno-enderbíticos e charnockitos.

Este agrupamento abrange granulitos, charnockitos e ortognaises migmatíticos de composição variando de charnockítica a enderbítica com termos mangeríticos, coloração variando de verde-escuro, cinzento a preto, aspecto homogêneo com granulação fina a média nos granulitos e finamente bandado nos gnaisses granulíticos; apresentam texturas granoblástica, granonematoblástica e granolepidoblástica e paragênese metamórfica com ortopiroxênio e plagioclásio, quartzo planar e, eventualmente clinopiroxênio e granada. 


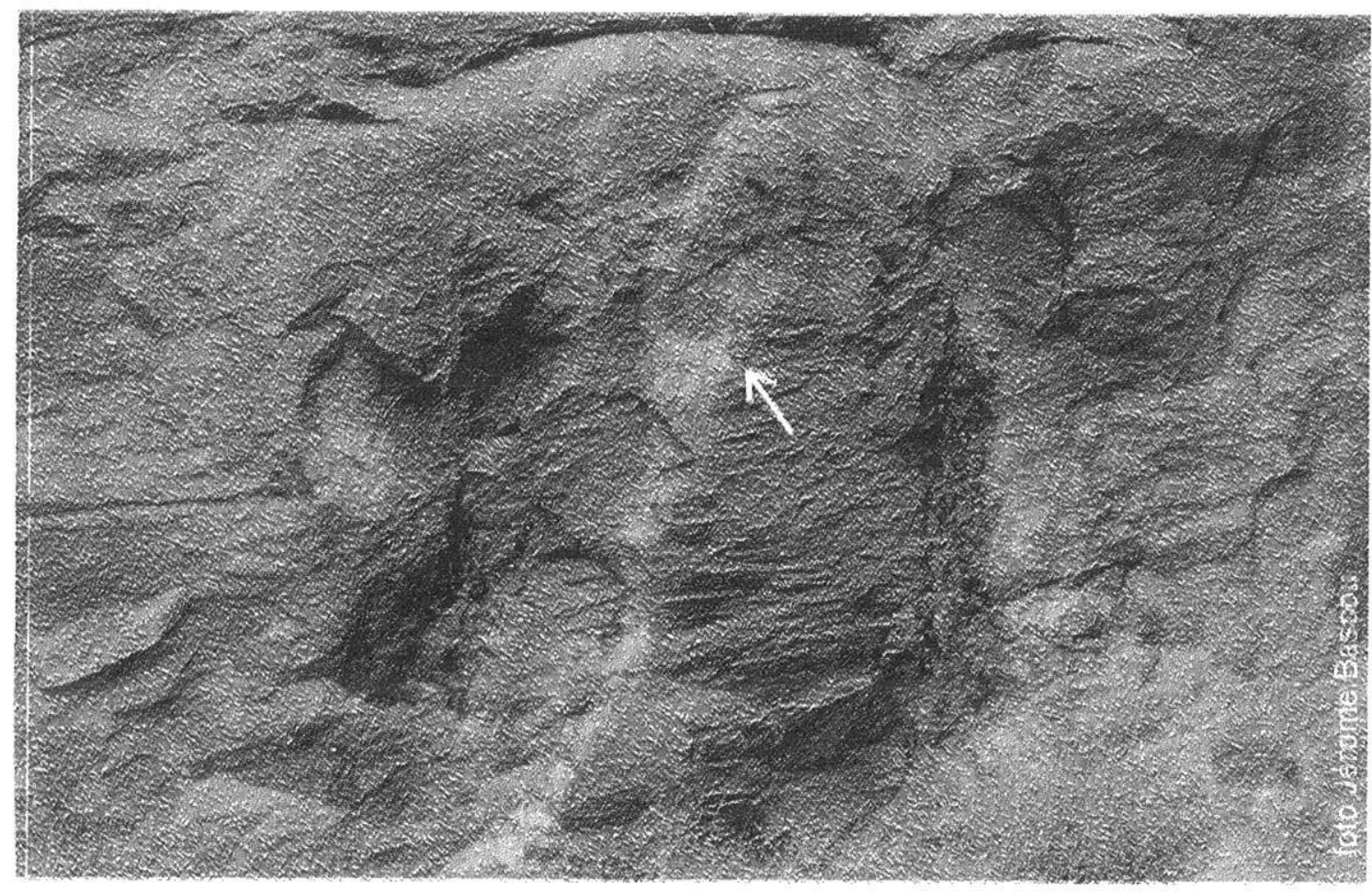

Fot. 3. Granada - hornblenda - biotita gnaisse (jfkz), com enclave de granulito, Complexo Juiz de Fora. Ponto KJ380, estrada Miracema - Pádua - Laranjal. (seta branca indica tampa da lente Nikon)

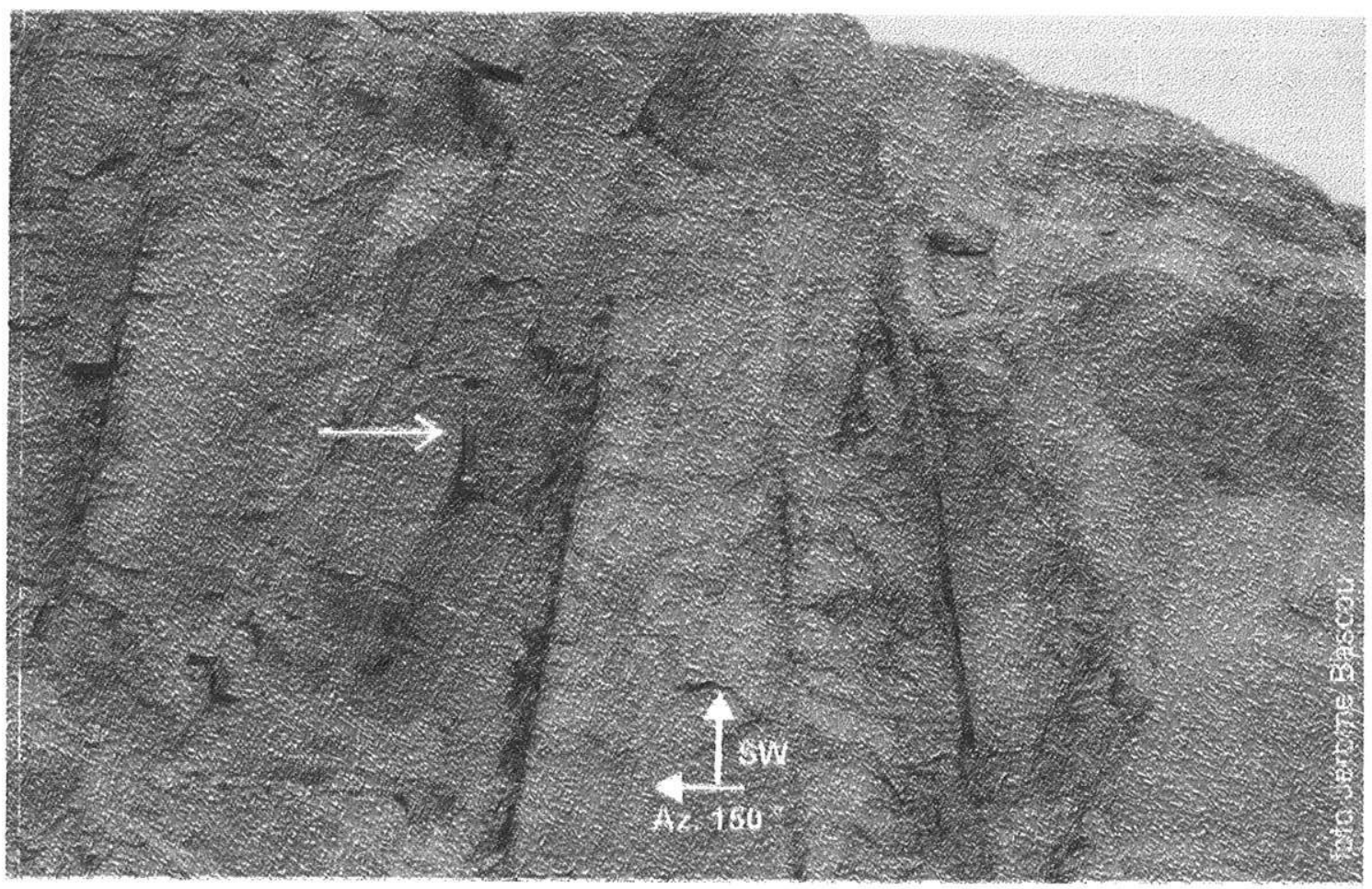

Fot. 4. Biotita - granada gnaisse granulítico (jfkz), Complexo Juiz de Fora. Ponto KJ378, estrada Miracema - Pádua.

(seta branca indica o martelo) 


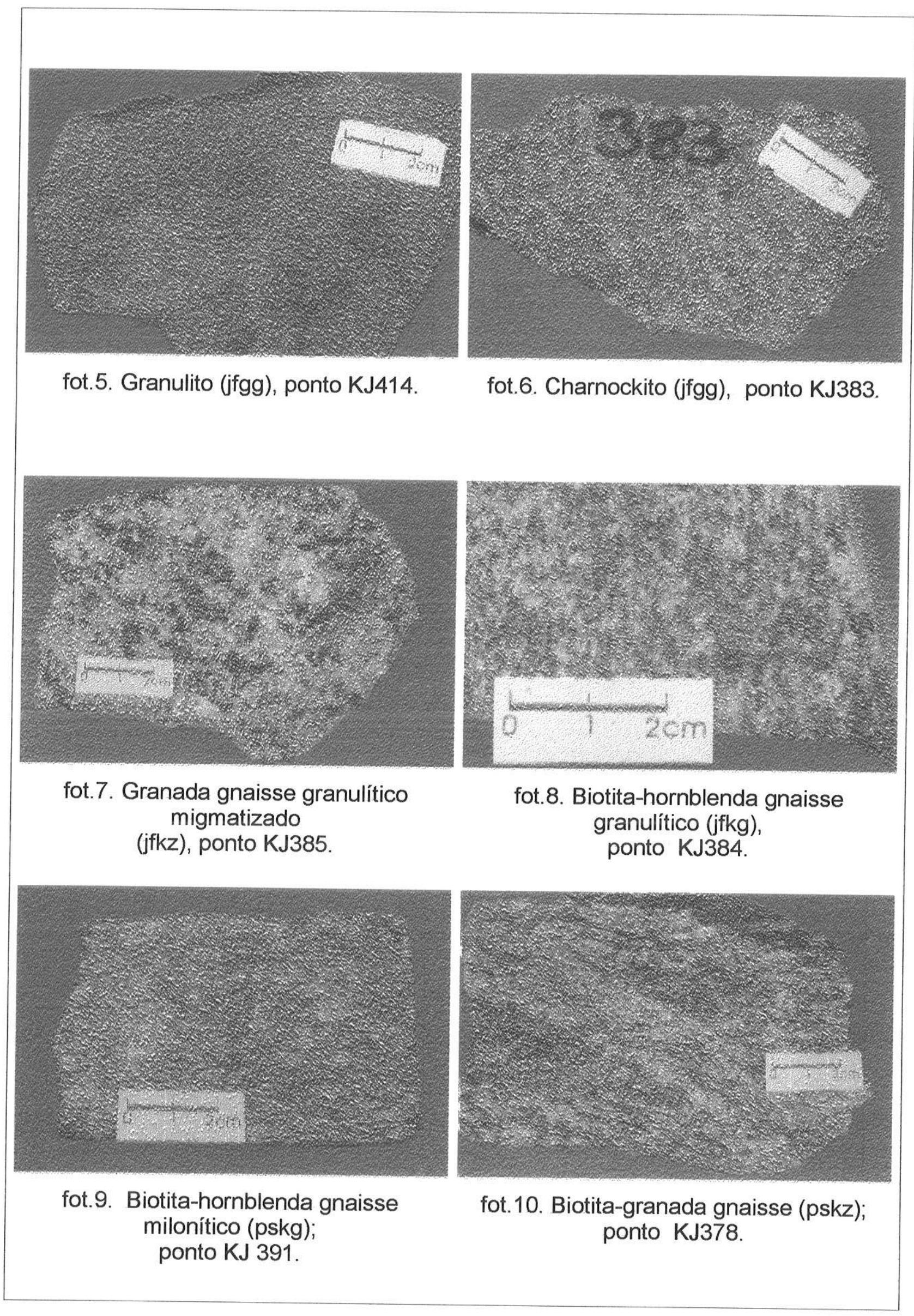

Prancha 3) Fotografias de amostras. 
Os charnockitos ocorrem associados aos granulitos, possuem aspecto homogêneo e maciço, com coloração esverdeada escura e granulação grossa, sem evidências de deformação (fot.6.).

Os charnockitos ocorrem nos limites oriental e ocidental da área, beirando as zonas de cisalhamento que limitam as intercalações dos complexos Paraíba do Sul e Juiz de Fora, com termos milonitizados no setor sudeste da área.

Apresentam textura granoblástica, granulação grossa, 3 a $4 \mathrm{~mm}$, cristais eqüidimensionais, poligonais, com contatos a $120^{\circ}$.

A composição mineralógica dos charnockitos consiste de: feldspato potássico, frequentemente pertítico, plagioclásio, ortopiroxênio, óticamente determinado como ferrossilita, quartzo poligonal, plagioclásio, clinopiroxênio, óticamente determinado como diopsídio (fig.A.10.), biotita em agregados de cristais pardo avermelhados, zircão subédrico elíptico, titanita, cordierita (fig.A.10.), monazita, magnetita e minerais opacos.

Os granulitos possuem coloração escura, aspecto homogêneo e maciço, granulação fina e textura granuloblástica (fot.5.). Apresentam fortes feições de recristalização ao microscópio, quartzo planar (discóide) (fig.A.21.) e formação de sub-grãos (fot.11.; fot.12.).

Os minerais constituintes dos granulitos são: plagioclásio; ortopiroxênio (ferrossilita); eventualmente clinopiroxênio (diopsídio); biotita; feldspato alcalino; quartzo discóide, eventualmente granada, óticamente determinada como almandina, minerais acessórios: zircão, ilmenita, magnetita, pirrotita e minerais opacos.

A composição varia de enderbítica a charno-enderbítica nos granulitos e predominantemente enderbítica no paleossoma dos ortognaisses granulíticos migmatíticos. Os gnaisses granulíticos apresentam bandas félsicas quartzo-feldspáticas e bandas máficas enderbíticas.

A composição mineralógica dos gnaisses granulíticos consiste de: plagioclásio em cristais milimétricos a submilimétricos, subédricos a anédricos, contatos regulares a irregulares, extinção ondulante, maclas levemente deformadas (fot.13.), por vezes apresentam núcleos alterados (fot.14.), provavelmente indicando composição mais cálcica no núcleo (fig.A.14.); feldspato alcalino pertítico, em cristais subédricos; quartzo em cristais subédricos a anédricos, em grãos poligonais com contatos a $120^{\circ}$ e forte extinção ondulante (fig.A.14.), formando mirmequitas no contato com plagioclásio; ortopiroxênio (ferrossilita) em cristais anédricos ou subédricos, em cristais maiores corroídos, de coloração rosa-salmão, extinção reta e clivagem nem sempre visível.

Apresentam textura em corona, piroxênio e hornblenda (fot.15.) e substituições por hornblenda, biotita e minerais opacos; clinopiroxênio (diopsídio) em cristais subédricos, incolores a verde-garrafa, associados à hornblenda e minerais máficos (fig.A.8.). 


\section{Prancha 4}

Foto 11) afloramento KJ442, lâmina KJ442t1 e Foto 12) afloramento KJ442, lâmina KJ442t2 - granulito; textura granoblástica, com forte recristalização e formação de sub-grãos. Detalhe do subgrão na foto da direita.

Foto 13) afloramento KJ452, lâmina KJ452a - granulito; plagioclásio levemente deformado associado a biotita primária, euédrica, inclusa no cristal e biotita secundária, cristalizada na borda do plagioclásio.

Foto 14) afloramento KJ387, lâmina KJ387ba - granada granulito; plagioclásio com saussuritização no centro do cristal, devido a um maior teor de cálcio no centro ou sobrecrescimento de uma fase menos cálcica com alteração posterior do núcleo do cristal.

Foto 15) afloramento KJ386, lâmina KJ3862 - migmatito de gnaisse granulítico; evidência de metamorfismo retrógrado, com hornblenda substituindo as bordas do cristal de piroxênio, formando uma corona.

Foto 16) afloramento $\mathrm{KJ} 387$, lâmina $\mathrm{KJ} 387 \mathrm{e}$ - granada granulito; biotita associada a duas gerações de mineral opaco (magnetita), a primeira como inclusão e a segunda como cristais bem desenvolvidos na borda e entrando nas clivagens da biotita.

Foto 17) afloramento KJ378, lâmina KJ378f - biotita-granada gnaisse granulítico; plagioclásio com inclusão de biotita e minerais opacos subédricos, primários e associada à biotita e minerais opacos secundários, nas bordas do cristal.

Foto 18) afloramento KJ387, lâmina $\mathrm{KJ} 387 \mathrm{~b}$ - granada granulito; monazita com halo pleocróico, em contato com biotita com óxidos em suas fraturas, minerais opacos subédricos nas bordas, sillimanita e granada. 


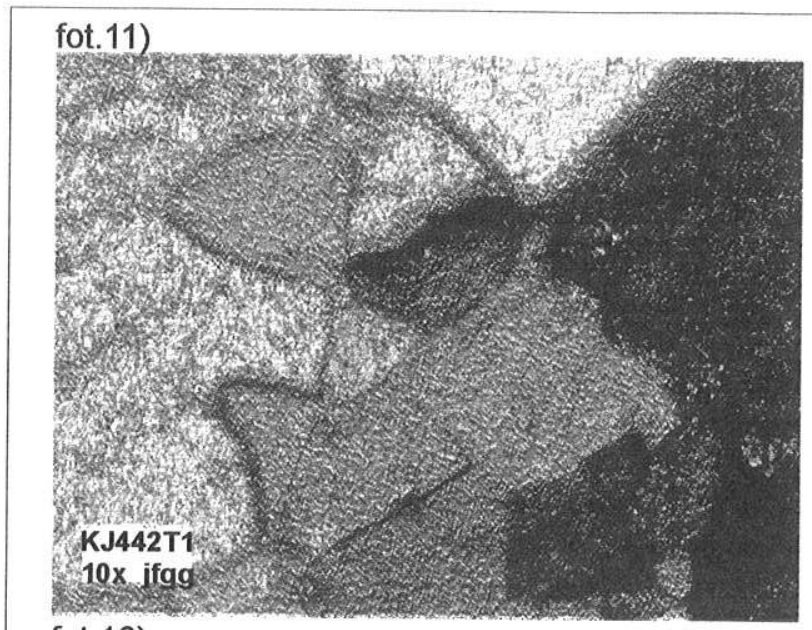

fot.13)

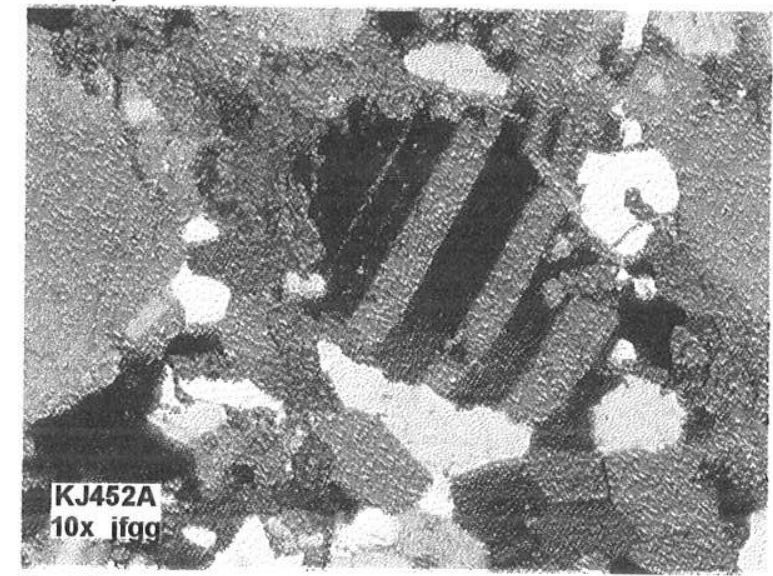

fot.15)

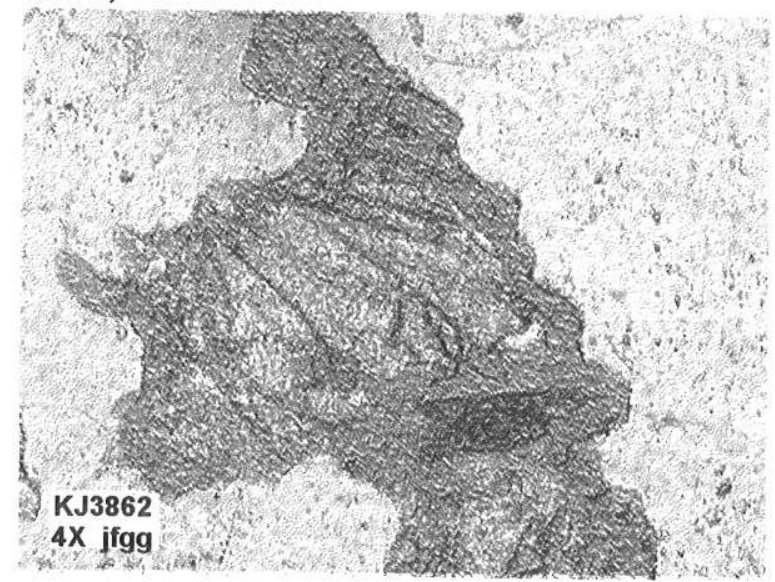

fot.17)

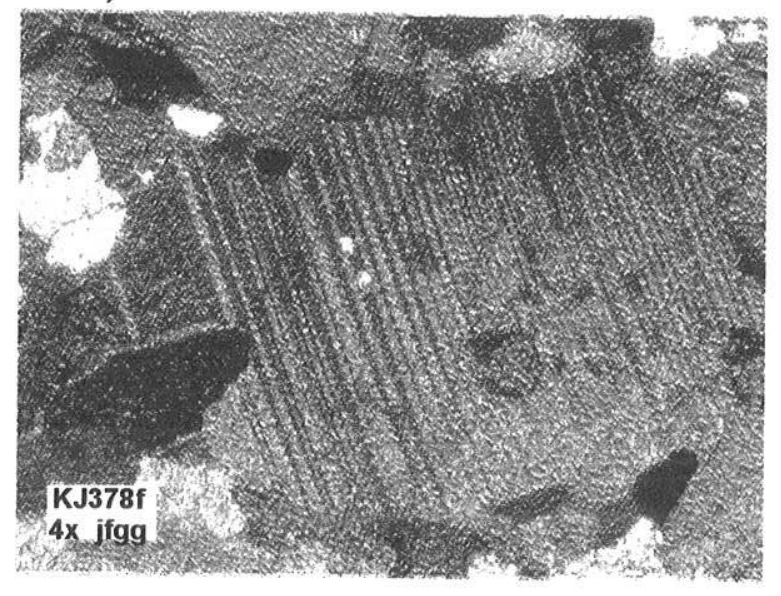

fot.12)

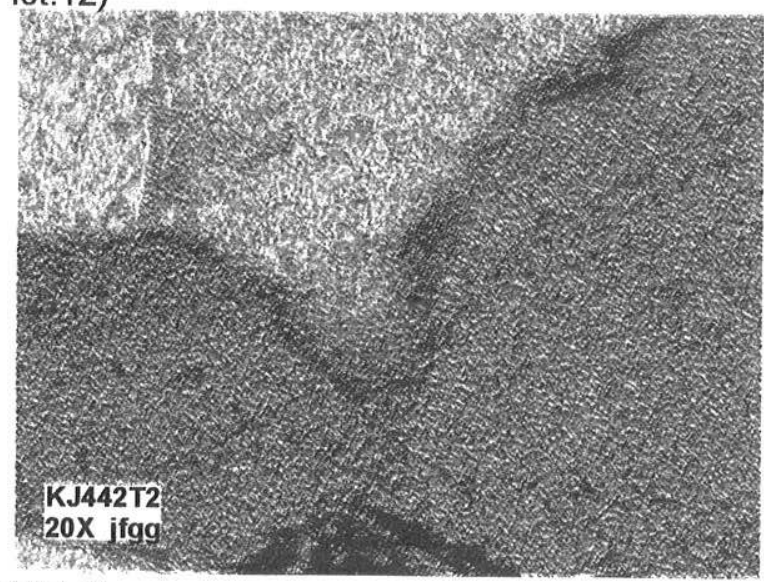

fot.14).

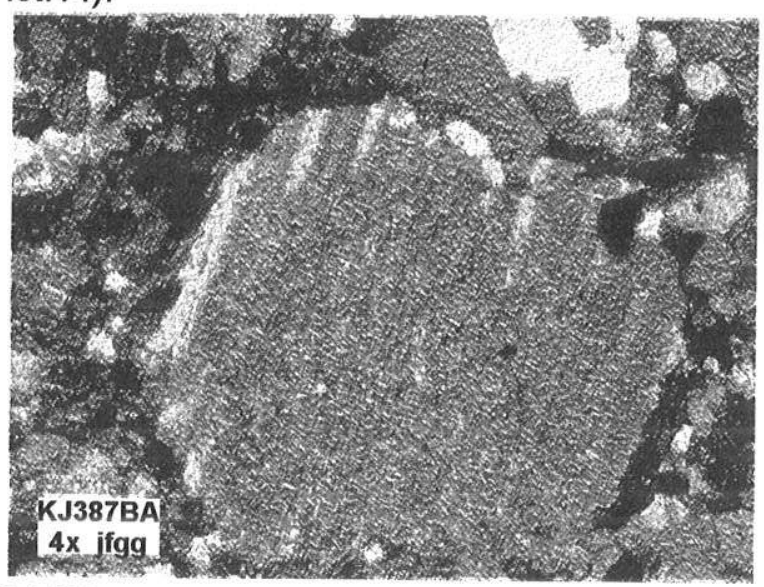
fot.16)

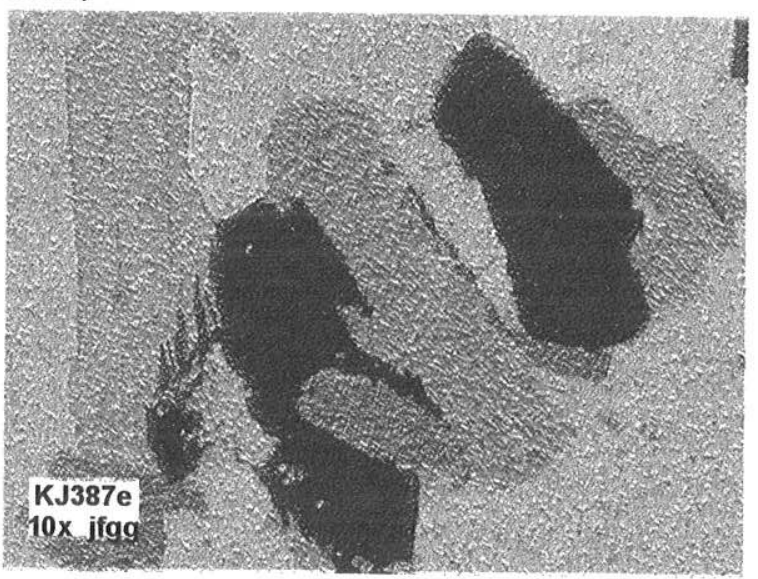

fot.18)

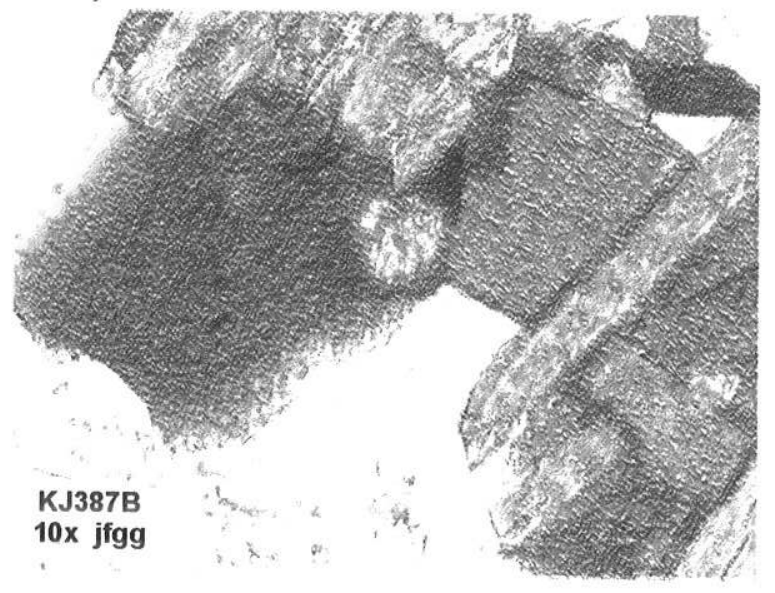


Apresentam anfibólio (hornblenda / actinolita) (fig.A.13.) em cristais anédricos a subédricos, pleocroísmo verde-escuro a verde-claro, por vezes castanho, com textura nematoblástica, mostrando os cristais bem orientados segundo a foliação principal e ocorrem minerais opacos de alteração, associados (fot.15.); biotita primária em palhetas e cristais maiores subédricos a anédricos, inclusa e/ou nas bordas de plagioclásio (fot.16; fot.17.), (fig.A.6.), com pleocroísmo pardo-amarronzado-avermelhado a pardo amareladoclaro e, frequentemente associada a produtos de reação de anfibólios e piroxênios; granada em cristais arredondados, fraturados, poiquiloblástica, com inclusões de quartzo e minerais opacos, reagindo para anfibólio, biotita e minerais opacos; ocorrências esparsas de sillimanita, em cristais anédricos a subédricos e de cordierita (fig.A.10.).

Os minerais acessórios são: zircão elíptico, com halos pleocróicos, ocasionalmente incluso nas biotitas; monazita em pouca quantidade, nas rochas com granada, em cristais arredondados (fot.18.) e apatita, ambos esparsos na matriz.

As litologias granulíticas contém óxidos de primeira e segunda geração (fot.19.) e também sulfetos, sendo seus minerais opacos: magnetita e ilmenita anédricos a subédricos, (fot.20.) ou na matriz, em cristais anédricos a subédricos bem orientados. Os sulfetos identificados, aparentemente secundários, são a pirrotita, bornita e calcopirita, nos granulitos e granada granulitos (fot.21.; fot.22.), (fig.A.17.).

\section{- (jfkg) - biotita- hornblenda gnaisses granulíticos}

Este agrupamento litológico compreende ortognaisses de composição enderbítica, com termos charno-enderbíticos, granulação média a fina, texturas granoblástica, nematoblástica e lepidoblástica (fot.8.). Apresentam evidências de retrometamorfismo para a fácies anfibolito alto, com paragênese anterior preservada, pois sempre apresentam piroxênio, que ocorre eventualmente associado ou quase totalmente substituído por hornblenda.

A composição mineralógica consiste de: plagioclásio (andesina a labradorita) em cristais subédricos, geralmente com hábito poligonal, macla polissintética e por vezes com bordas irregulares, apresentam saussuritização no centro dos cristais maiores provavelmente por seu maior teor em cálcio do que os plagioclásios da matriz; feldspato alcalino, em cristais subédricos, biotita ocorre em palhetas euédricas (fig.A.19.) marcando a foliação principal, pleocroismo castanho a castanho-claro, inclusões de zircão; anfibólio, oticamente determinado como hornblenda, em cristais subédricos, com pleocroismo verdeescuro forte a verde-claro amarelado, orientados segundo a foliação principal, na matriz e, associados a cristais de biotita e opacos (fot.23.), apresentando textura poiquiloblástica com inclusões de quartzo, apatita, minerais opacos anédricos e monazita. 


\section{Prancha 5}

Foto 19) afloramento KJ386, lâmina KJ386b - granulito; biotita com inclusão de magnetita, com magnetita secundária nas bordas dos cristais de biotita. cristal de piroxênio parcialmente substituido por anfibólio na borda. Cristais de biotita e hornblenda oxidados.

Foto 20) afloramento KJ386, seção polida KJ386m - granulito; magnetita, cinza azulado; martita (exsolução de magnetita e hematita, rosado claro, centro preservado), 10x.

Foto 21) afloramento KJ457, seção polida KJ4573 - biotita-granada gnaisse granulítico; magnetita e hematita intercrescidos (cinza azulado canto inferior direito do agregado); ilmenita (cinza escuro, abaixo da hematita); pirrotita (rosa amarelado no centro do agregado); calcopirita (amarelo no canto inferior esquerdo do agregado), bornita (azulado no centro, com pirrotita), 10x.

Foto 22) afloramento KJ457, seção polida KJ457b - biotita- granada gnaisse granulitico; pirrotita (amarelo claríssimo no lado direito do agregado); calcopirita (amarelo vivo-claro no lado direito do agregado); pirita (amarelo vivo-escuro, lado direito do agregado); ilmenita (cinza escuro, menor), $10 x$.

Foto 23) afloramento $\mathrm{KJ} 429$, lâmina $\mathrm{KJ} 429 \mathrm{~b}$ - biotita - hornblenda gnaisse granulítico; minerais máficos em equilíbrio; biotita, hornblenda e minerais opacos acompanham a foliação principal da rocha. Cristal de piroxênio com anfibólio nas fraturas e opacos nas bordas.

Foto 24) afloramento $\mathrm{KJ} 448$, seção polida $\mathrm{KJ} 4483$ - biotita hornblenda gnaisse granulitico; magnetita (cinza azulado no canto inferior esquerdo da foto e canto superior direito em cristal menor); ilmenita (azul-avermelhado) intercrescido com magnetita, martita (magnetita + hematita) (amarelo +rosa claro); bordas de reação da ilmenita e hematita reagindo com silicato, canto superior esquerdo, $20 x$.

Foto 25) afloramento KJ454, seção polida KJ4541 - biotita- hornblenda gnaisse granulítico; cristal de ilmenita (cinza rosado-azulado-claro) intercrescida com magnetita (cinza azulado claro no lado direito), $10 x$.

Foto 26) afloramento KJ419, seção polida KJ419 - hornblenda- biotita gnaisse granulítico; magnetita (cinza azulado), com exsoluções de hematita (rosado), 10x. 


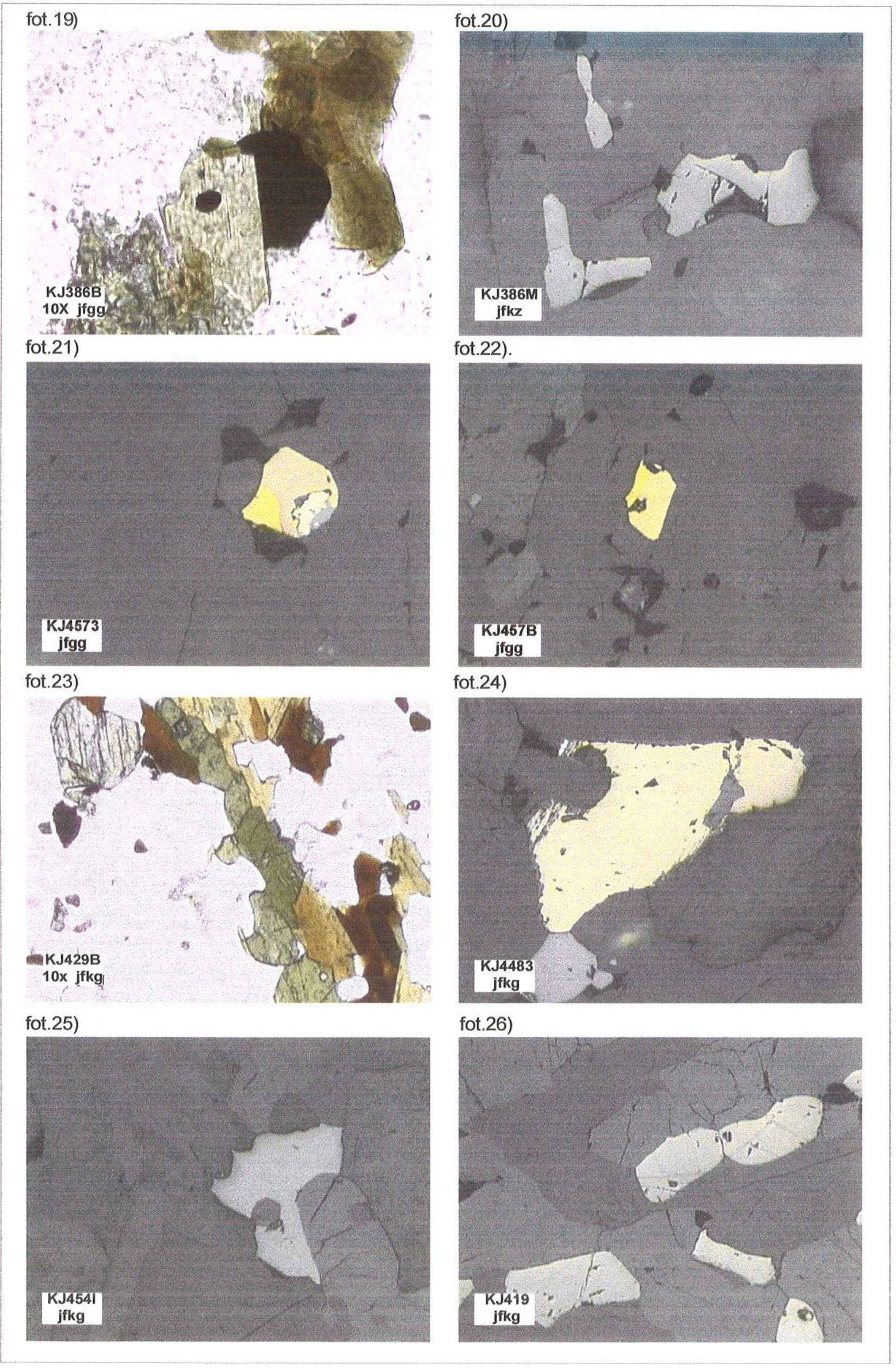

Prancha 5) Fotomicrografias 
O ortopiroxênio (ferrossilita) ocorre em porfiroblastos com inclusões de minerais opacos e, por vezes parcialmente substituídos por hornblenda e biotita; clinopiroxênio (diopsidio) (fig.A.10.) em pouca quantidade, com cristais anédricos a subédricos, associados à hornblenda $\mathrm{O}$ quartzo ocorre em pouca quantidade (ou inexiste) em cristais subédricos a anédricos, com extinção ondulante, poligonais e recristalizados.

Os minerais acessórios são: zircão em cristais euédricos, inclusos nas biotitas ou associados aos minerais máficos; apatita acicular, inclusa no plagioclásio ou esparsa na matriz; titanita subédrica, associadas aos opacos.

Os minerais opacos identificados ocorrem como óxidos primários anédricos a subédricos, associados com os ferromagnesianos, como anfibólio e biotita. A magnetita (fot.24.) é frequente, ocorrendo associada com ilmenita (fot.25.) em cristais anédricos a subédricos, orientados segundo as fraturas do anfibólio e/ou piroxênio, mostrando intercrescimentos de hematita e ilmenita (fot.26.). Os sulfetos identificados foram: pirrotita e goethita (fot.27.), calcopirita, pirita (fot.28.); bornita e covelina (fot 29.).

\section{- (jfkz) - biotita-granada gnaisses granulíticos}

Estas litologias abrangem paragnaisses granulíticos de composição variada, de charnockítica a enderbítica, granulação fina a média, textura granolepidoblástica, (localmente augen). Apresentam estrutura bandada, com bandas félsicas compostas de feldspatos, granada e quartzo, com textura granoblástica e bandas máficas compostas de biotita, piroxênio e (localmente) anfibólio, com textura nematoblástica e lepidoblástica (fot.7.) (fot.38.) (fig.A. 14.). Sua origem metassedimentar fica evidenciada por intercalações frequentes de rochas cálcio-silicáticas, lentes de mármore, quartzitos feldspáticos, gnaisses com sillimanita e enclaves de granulitos máficos (fot.3.).

A composição mineralógica destas rochas consiste de plagioclásio (labradorita a bitownita) em cristais anédricos a subédricos (1 a $2 \mathrm{~mm}$ ), com contatos regulares, ou como porfiroblastos ( 3 a $4 \mathrm{~mm}$ ) subédricos, desenvolvendo mirmequita no contato com quartzo (fot.30.); quando na matriz, o plagioclásio mostra cristais límpidos e maclados; feldspato alcalino (microclínio) em megacristais ou em cristais menores, dispersos na matriz; quartzo em cristais de granulação muito fina, arredondados, textura granoblástica, em fitas orientadas segundo a foliação principal; biotita em cristais pardo- avermelhados orientados segundo a foliação principal da rocha, associados à sillimanita e aos minerais máficos, ou em agregados de cristais subédricos, sem orientação (fot.31.), com inclusões de minerais opacos e zircäo; ortopiroxênio em cristais subédricos, rosados ou esverdeados, com inclusões orientadas de minerais opacos, com contatos retilíneos com os plagioclásios. 


\section{Prancha 6}

Foto 27) afloramento KJ451, seção polida KJ451pg - biotita- hornblenda gnaisse granulítico; pirita (amarelo pálido com tintas rosamclaras), calcopirita (amarelo canário, cristal menor no centro- esquerda da pirita), pirrotita (borda esquerda rosa na pirita), 10x.

Foto 28) afloramento KJ451, seção polida KJ451p - biotita- hornblenda gnaisse granulítico; pirita (cristal amarelo com riscos do polimento), calcopirita (amarelo canário, incluso na pirita, centro-superior), pirrotita (rosado claro, incluso na pirita, centro-superior), $10 \mathrm{x}$.

Foto 29) afloramento KJ448, seção polida KJ448 - biotita- hornblenda gnaisse granulítico; magnetita e hematita intercrescidos (mistura de lamelas rosada e azulada parte inferior do grão), pirita (amarelo forte), ilmenita e magnetita intercrescidos (cinza escuro e cinza claro em pequeno cristal no centro do agregado), pirrotita (amarelo com tintas rosa, centro superior do agregado), óxido de alteração nas bordas do agregado, bornita (azul em pequenos cristais na borda superior direita da pirita), crescimento de magnetita nas fraturas do silicato (parte inferior do agregado, lamelas cinza azuladas), 10x.

Foto 30) afloramento $\mathrm{KJ} 381$, lämina $\mathrm{KJ} 381 \mathrm{~m}$ - biotita-granada gnaisse granulítico; simplectitos de quartzo nos contatos com plagioclásio e feldspato potássico (mirmequita), fitas de quartzo recristalizado ao redor do palgioclásio, biotita de primeira e segunda geração.

Foto 31) afloramento $\mathrm{KJ} 382$, lâmina $\mathrm{KJ} 382$ bo - granada- hornblenda- biotita gnaisse granulítico; agregado de biotita associada com minerais opacos com inclusões de apatita. Os minerais opacos ocorrem em cristais subédricos maiores nas bordas da biotita ou como cristais diminutos em suas fraturas.

Foto 32) afloramento $\mathrm{KJ} 378$, lâmina $\mathrm{KJ} 378 \mathrm{c}$ - granada- biotita gnaisse granulitico; cristal de granada, possivelmente sincinemático (presença de fraturamento intenso) com cristais de plagioclásio, biotita e minerais opacos nas fraturas.

Foto 33) afloramento KJ446, lâmina $\mathrm{KJ} 446 \mathrm{~b} 2$ - biotita- granada gnaisse granulítico; formação de biotita a partir de granada, evidenciando reequilíbrio na fácies anfibolito.

Foto 34) afloramento KJ424, lâmina KJ4243c - biotita - granada gnaisse granulítico; retrometamorfismo com evidências de reequilibrio na fácies anfibolito; cristal de granada sendo substituído por biotita e opacos; presença de 2 gerações de biotita e de minerais opacos formados com a biotita secundária. 

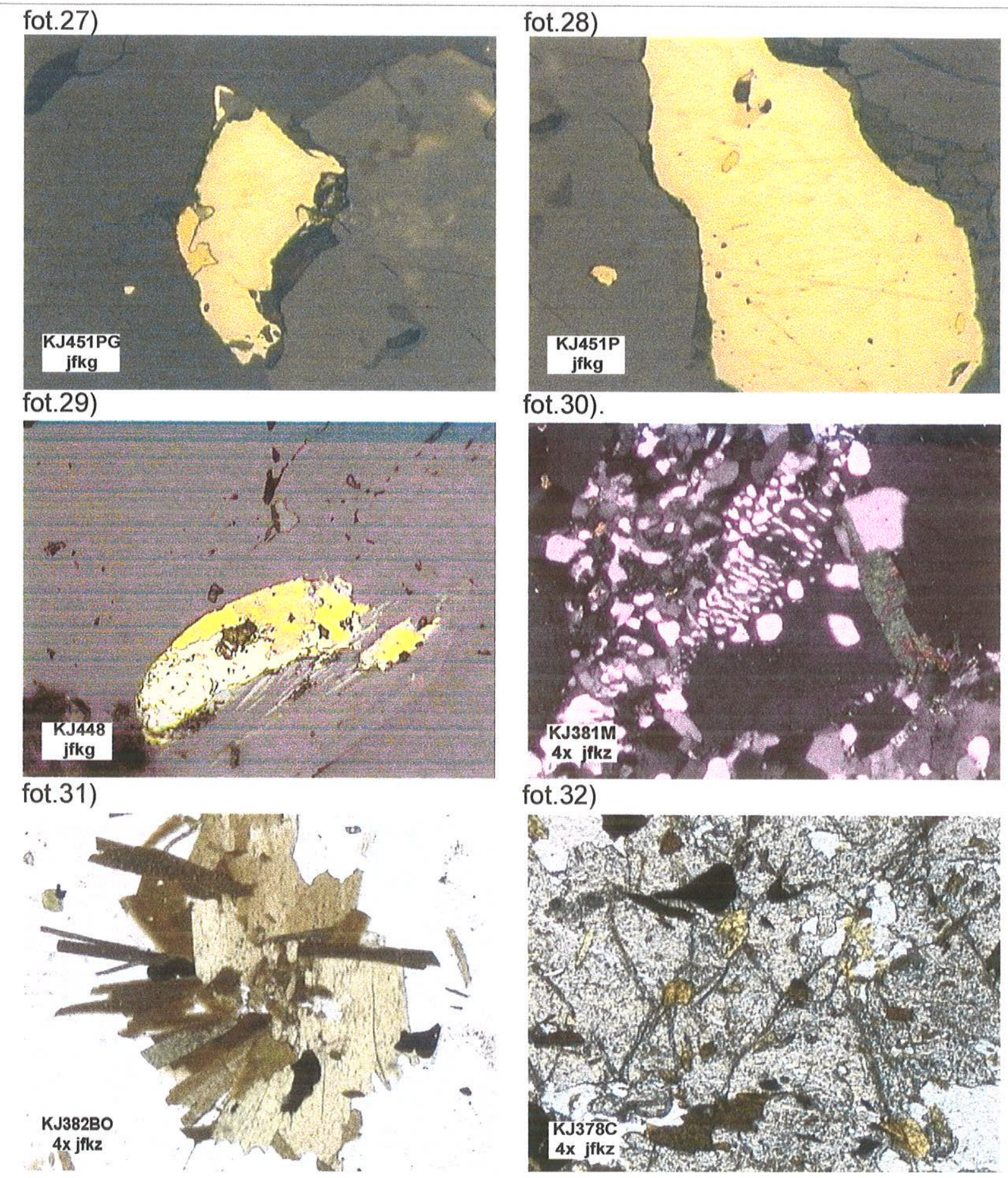

fot.30).

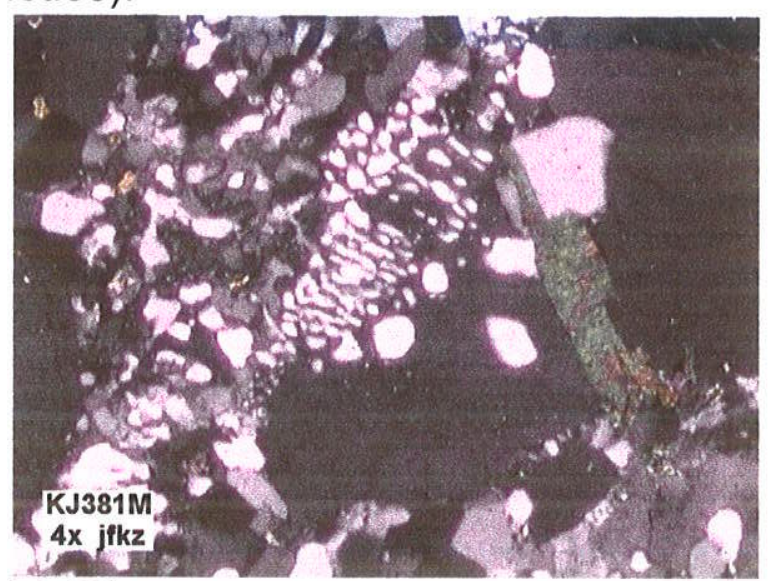
fot.32)

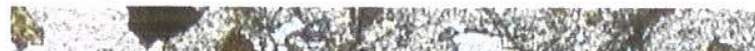

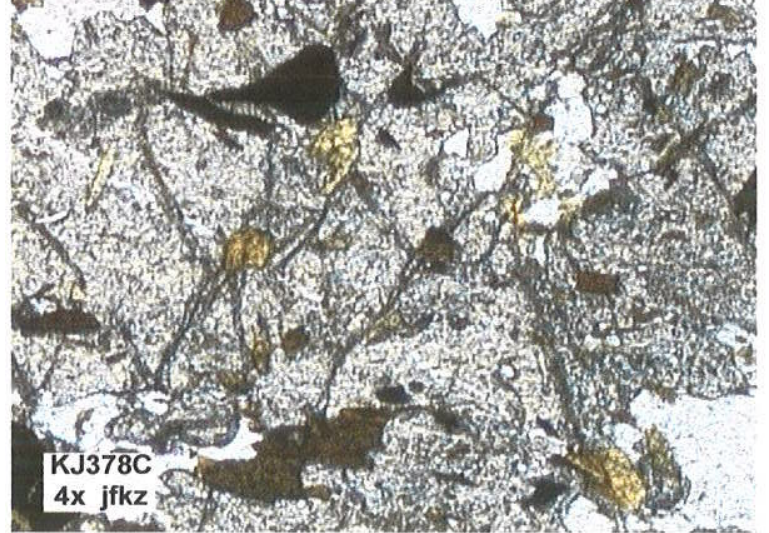

fot.33)

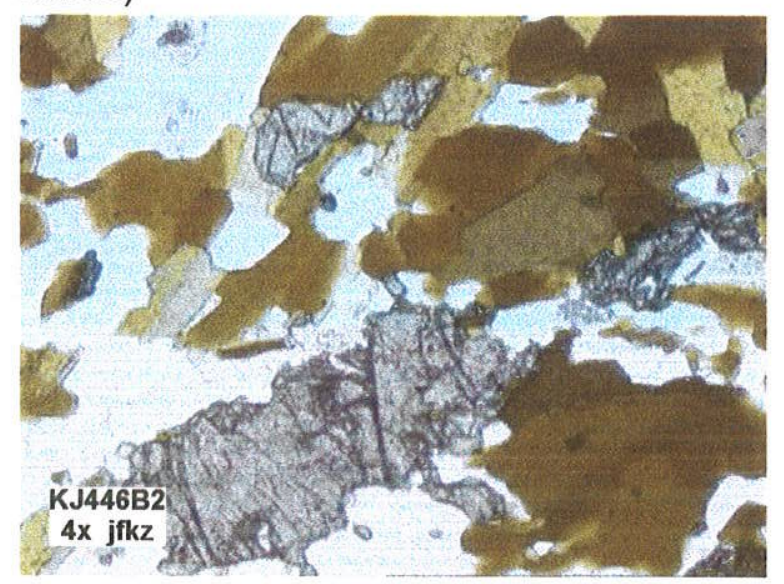
fot.34)

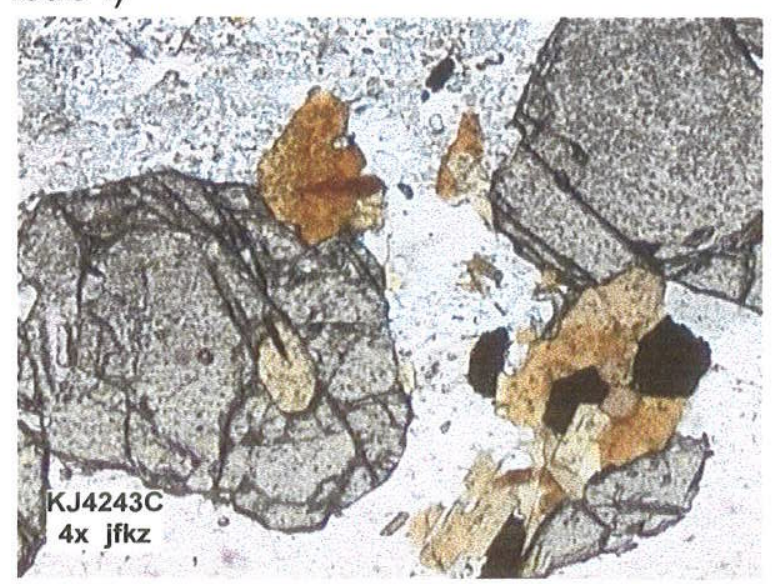

Prancha 6) Fotomicrografias 
O anfibólio (hornblenda) ocorre em cristais subédricos a anédricos, com pleocroísmo verde-pardo a verde-claro, límpido, com contornos regulares, associado à biotita e minerais opacos; granada (almandina) em cristais euédricos a subédricos, de 1 a $4 \mathrm{~mm}$, (fot.32.), (fig.A.7.), rosados, pleocroísmo forte e relevo alto, fraturados e corroídos nas bordas, em nítida associação com biotita (fot.33.; fot.34.); mostra textura poiquiloblástica, com inclusões de opacos e biotita; sillimanita em cristais prismáticos incolores, intercrescidos com a biotita, com clivagem bem marcada.

Os minerais acessórios são: zircão anédrico, por vezes incluso nas biotitas; apatita acicular e dispersa na matriz; monazita em cristais diminutos, arredondados e esparsose cordierita.

Os minerais opacos estão distribuidos ao longo das fraturas da homblenda e biotita e também dispersos na rocha em cristais submilimétricos a milimétricos, subédricos a anédricos, associados aos minerais ferromagnesianos e ocasionalmente alterados ou inclusos nos cristais de biotita.

Os óxidos identificados foram magnetita, associada à hematita e ilmenita. A hematita mostra substituições para ilmenita (fot.37; fot.38.) e ocorre também intercrescida com titanita. Os sulfetos identificados ocorrem como minerais secundários, associados aos minerais ferromagnesianos, em cristais subédricos a anédricos de bornita, goethita e calcopirita.

\subsection{Complexo Paraíba do Sul}

O Complexo Paraíba do Sul engloba as rochas supracrustais (fot.35.) que ocorrem no sudeste da área estudada, onde predominam os gnaisses com microclínio, biotita e hornblenda, milonitizados (fot.9.) intercalados com os gnaisses granatíferos miloniticos (fot.10.) em lentes de orientação preferencial nordeste, em contatos tectônicos entre si e com as litologias do Complexo Juiz de Fora, apresentando enclaves de gnaisses granulíticos, lentes de anfibolito, mármore e veios de quartzo. Na região de Santo Antônio de Pádua, estas rochas são localmente cortadas por granitóides milonitizados pertencente à Suíte Intrusiva Espírito Santo (fot.36.).

- (pskg) - biotita hornblenda gnaisses com microclínio, de composição monzonítica, cor acinzentada e bandamento gnáissico regular, granulação média a grossa, com textura granoblástica ou localmente porfiroblástica, migmatizados localmente e milonitizados (fot.9.). 


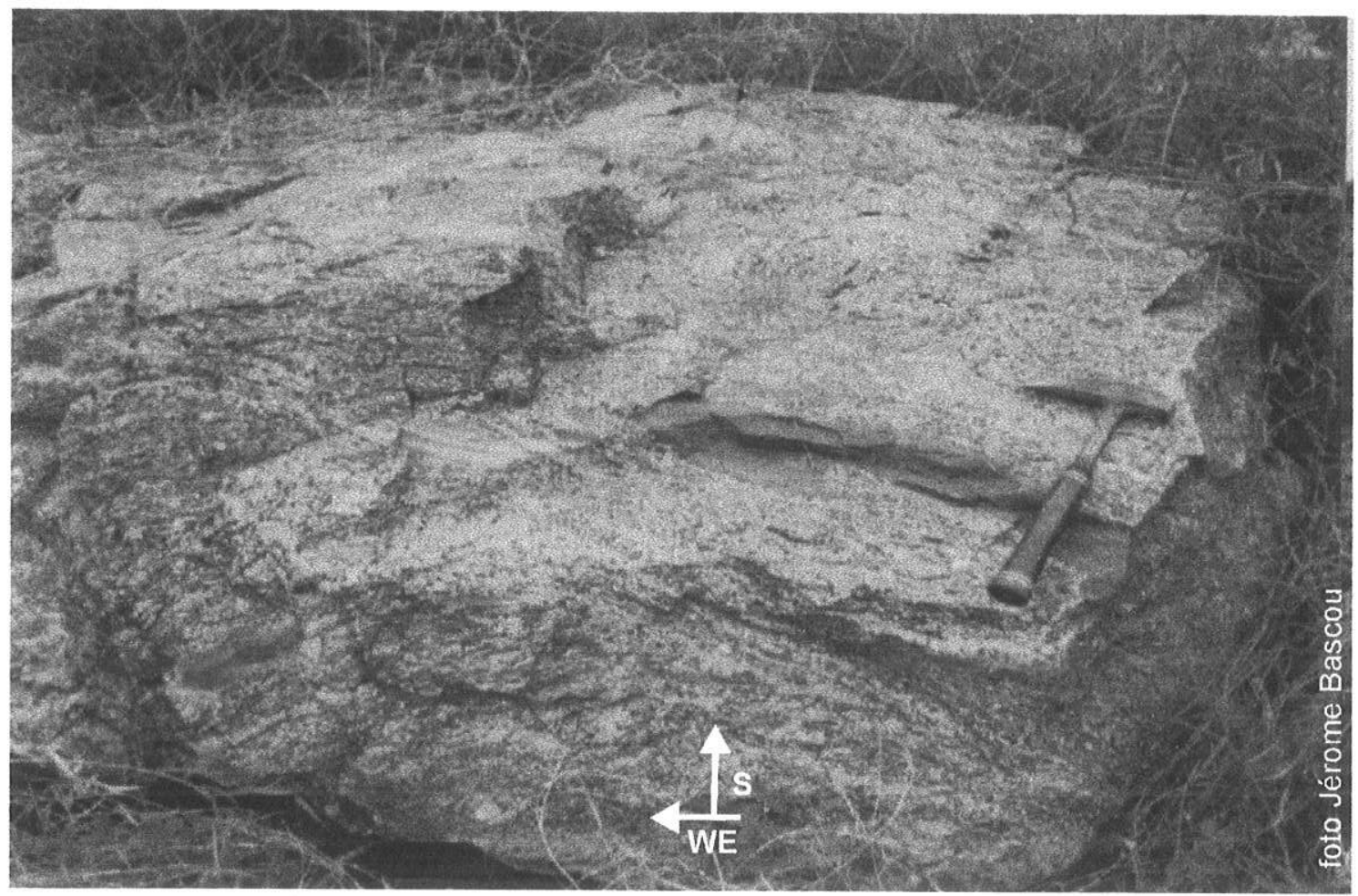

Fot. 35. Biotita - hornblenda - granada gnaisse (pskg), Complexo Paraíba do Sul. Ponto KJ384, estrada Muriaé - Comendador Venâncio.

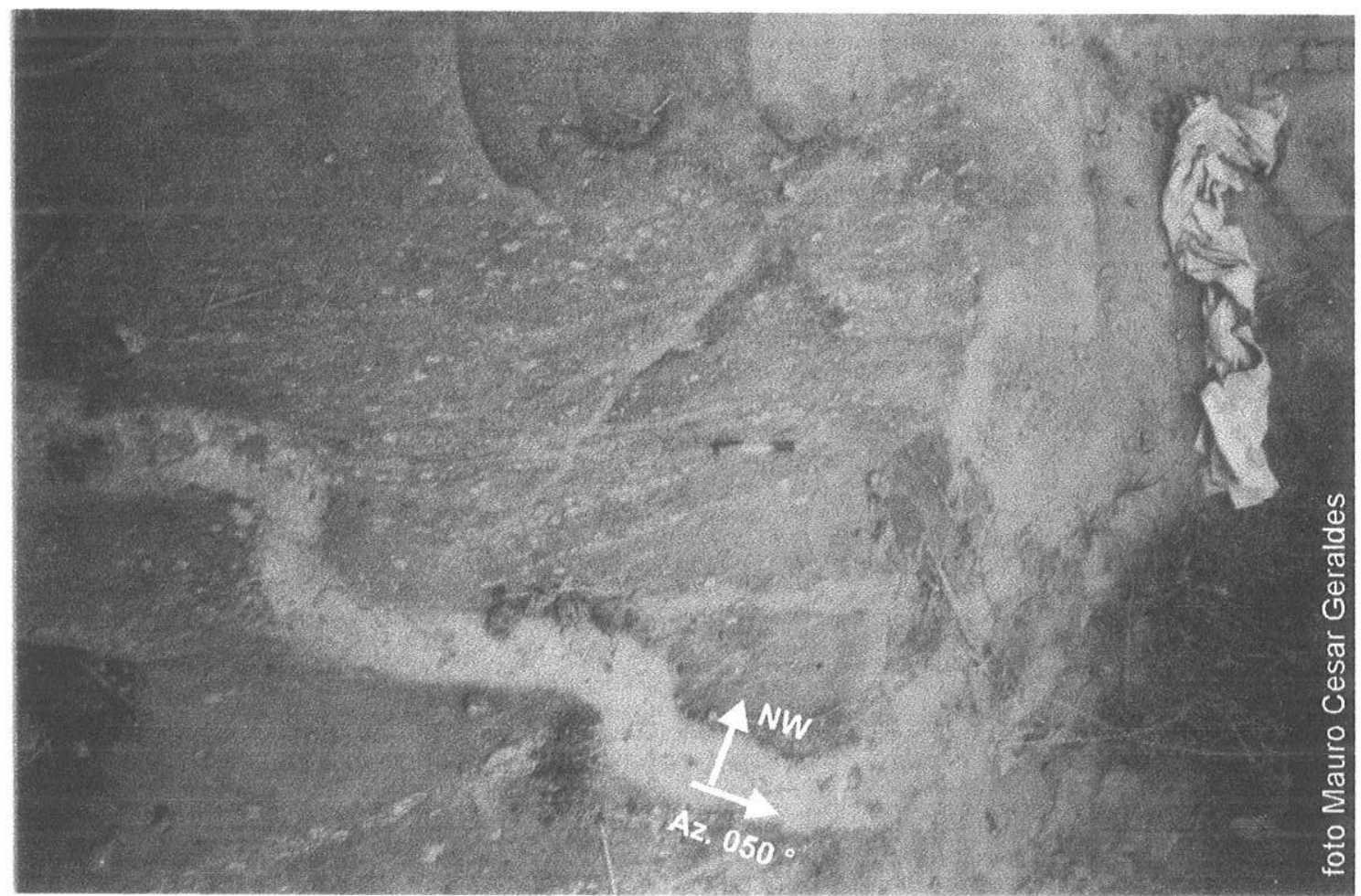

Fot. 36. Granito porfirítico (ges), Suíte Intrusiva Espírito Santo, em contato com hornblenda-biotita gnaisse granulítico (jfgg),cortado por dique granítico paralelo à zona de cisalhamento.

Ponto KJ415, estrada Miracema - Lage do Muriaé. 
A composição mineralógica destas rochas é: feldspato potássico em porfiroblastos subédricos a euédricos de microclínio (fot.39.), límpidos, com contornos levemente irregulares, alguns fraturados, preenchidos por epidoto e quando na matriz, estão recristalizados, com contatos a $120^{\circ}$ entre as bordas, circundando os porfiroblastos (fot.40.). O microclínio apresenta inclusões biotita e de apatita acicular e bastonada, hornblenda e minerais opacos anédricos; plagioclásio (oligoclásio) em porfiroblastos com contornos regulares e graus variáveis de saussuritização, maior no núcleo dos cristais e, quando na matriz, em cristais anédricos, diminutos e com bordas corroídas (fot.40.); quartzo em cristais anédricos de bordas corroídas, forte extinção ondulante e formação de sub-grãos e em cristais límpidos, subédricos de tamanho menor.

Biotita em agregados de palhetas, associada aos cristais de anfibólio e também em porfiroblastos, subédricos a anédricos com contornos levemente corroídos e plecroísmo pardo-claro, com freqüentes inclusões de quartzo anédrico, orientados segundo a foliação principal da rocha; anfibólio (hornblenda) em cristais anédricos a subédricos, clivagens bem definidas, pleocroismo forte variando de verde-muito-escuro a pardo-médio, associados com biotita, magnetita e ilmenita (fot.41; fot.42.).

Os minerais acessórios são: zircão, titanita subédrica, apatita acicular e carbonato. Os minerais opacos identificados ocorrem como cristais anédricos, arredondados, associados aos minerais máficos. Os óxidos são: ilmenita, magnetita (fot.46.) e hematita intercrescidos (fot.42.) e os sulfetos: pirrotita e calcopirita (fot.42.).

\section{- (pskz) - biotita-granada gnaisses}

As rochas desta associação mostram composição sienogranítica, granulação fina a média, félsicos, com textura geral granolepidoblástica (fot.45.), milonitizados, com feições de deformação e recristalização (fot.10.).

A composição mineralógica destas rochas consiste de: plagioclásio, em cristais subédricos; feldspato alcalino (oligoclásio) em cristais subédricos a euédricos, na matrize como porfiroblastos límpidos, maclados, com contatos levemente irregulares e extinção ondulante; microclínio em grãos poligonais na matriz; quartzo em cristais subédricos, granulação fina, freqüentemente orientados, com forte extinção ondulante, textura granoblástica e ribbons, biotita (fot.46.) em pequenas ripas, com pleocroísmo de pardoavermelhado forte a pardo-amarelado claro, associadas ou inclusas na granada e aos minerais opacos; quando presente na matriz, ocorre em agregados de cristais esparsos, com pleocroísmo castanho a pardo-claro, anfibólio, associado às bandas máficas, em cristais subédricos a anédricos, coloração verde escura ou cinzento-esverdeada (fot.47.), associados à biotita, quartzo e óxidos e com inclusões de minerais opacos. 


\section{Prancha 8}

Foto 37) afloramento $\mathrm{KJ} 427$, seção polida $\mathrm{KJ} 427$ - biotita-granada gnaisse granulítico; magnetita (cristal triangular cinza azulado incluso na martita), martita em cristais maiores, em lamelas de exsolução de hematita (cinza rosado) e magnetita (cinza azulado), 20x.

Foto 38) afloramento $\mathrm{KJ} 427$, seção polida KJ427b - biotita-granada gnaisse; magnetita em cristal corroído nas bordas, reagindo com o silicato, mostrando apenas o centro preservado, $20 x$.

Foto 39) afloramento KJ423I, lâmina KJ423I - biotita - hornblenda gnaisse; microclínio com inclusão de biotita e magnetita na borda.

Foto 40) afloramento KJ413, seção polida KJ413f - hornblenda- biotita gnaisse; textura granoblástica; microclinio em grão poligonais na matriz do gnaisse, associado à biotita e minerais opacos primários e secundários.

Foto 41 ) afloramento KJ418, lâmina KJ418a - biotita- hornblenda gnaisse; formação de magnetita e ilmenita a partir de megacristal de hornblenda.

Foto 42) afloramento KJ418, seção polida KJ418am - biotita-hornblenda gnaisse; magnetita em cristal subédrico, intercrescido com hematita (cristal rosa salmão), ilmenita (cinza escuro) nas bordas de calcopirita, pequenos cristais de óxido secundário, $20 \mathrm{x}$.

Foto 43) afloramento KJ423, seção polida KJ423 - hornblenda- biotita gnaisse; magnetita (cristal maior cinzento azulado), bornita (cristal menor rosado, acima da magnetita), reação com silicato nas bordas e fraturas dos óxidos, 10x.

Foto 44) afloramento KJ423, seção polida KJ423m - hornblenda- biotita gnaisse; magnetita intercrescida com ilmenita no núcleo do cristal (cinza azulado médio), zonação com magnetita alterada nas bordas, magnetita em cristais com reflexão interna no lado direito do cristal, associada a óxidos de alteração na borda superior e fratura, 20x. 

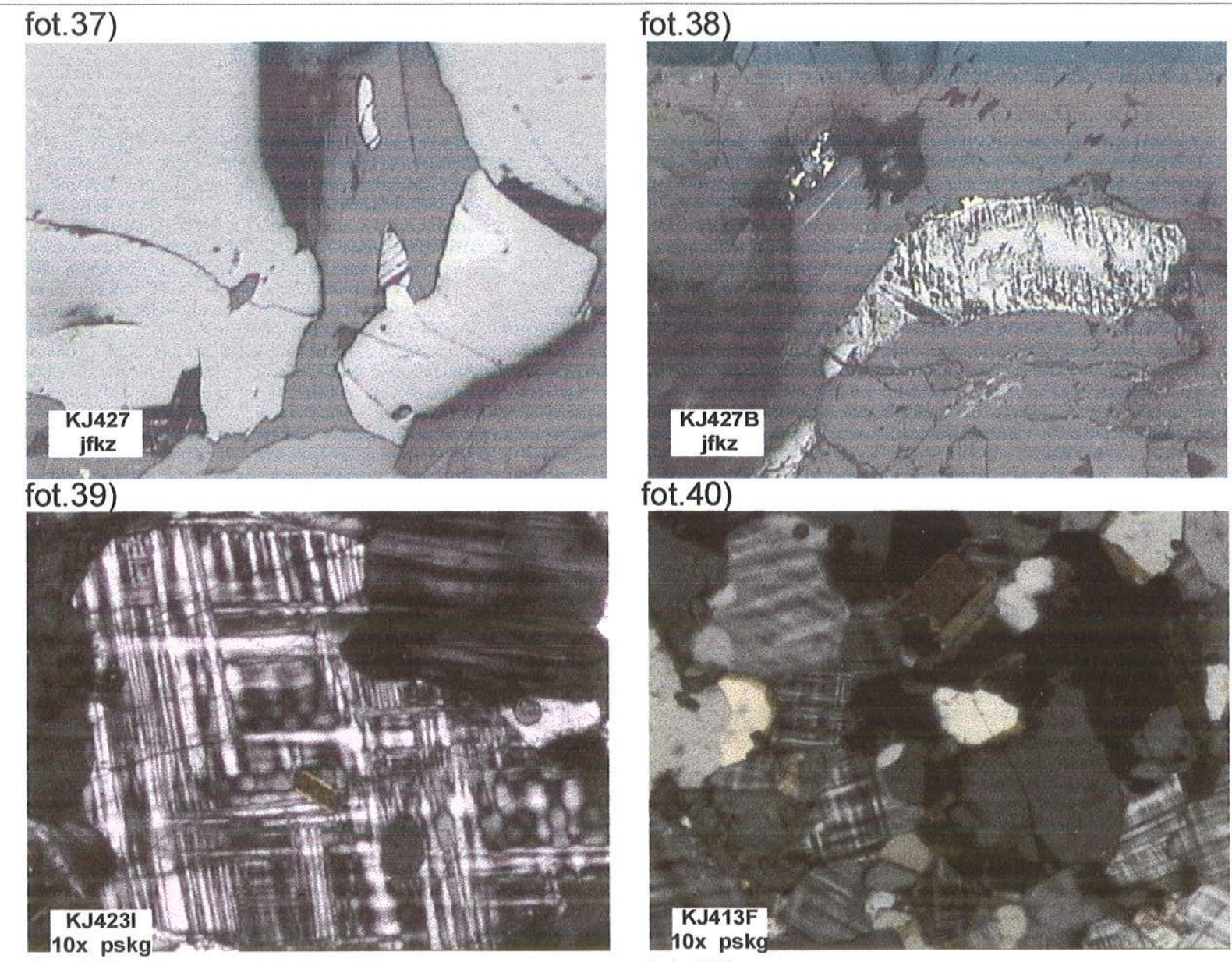

fot.41)

fot.40)
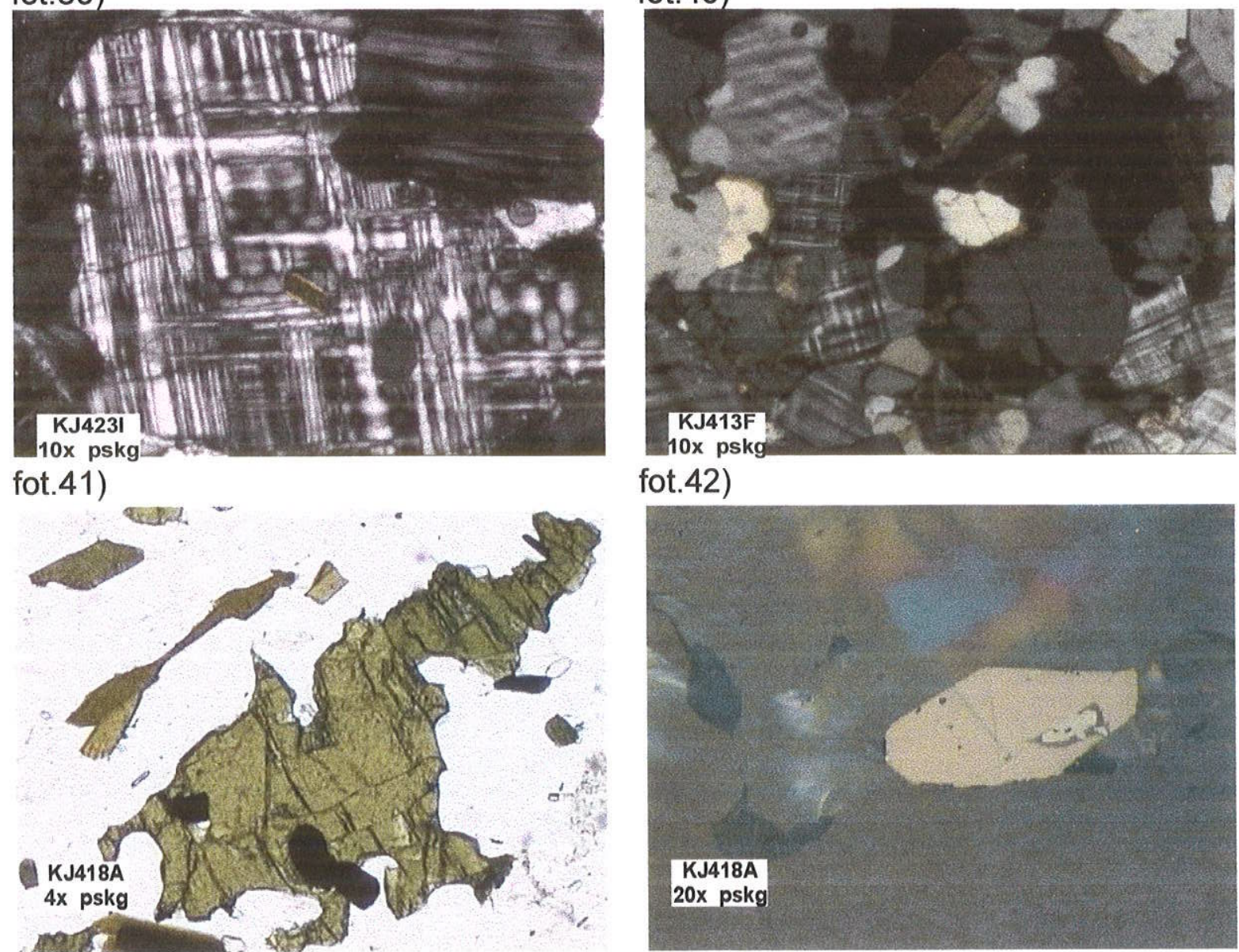

fot.42)

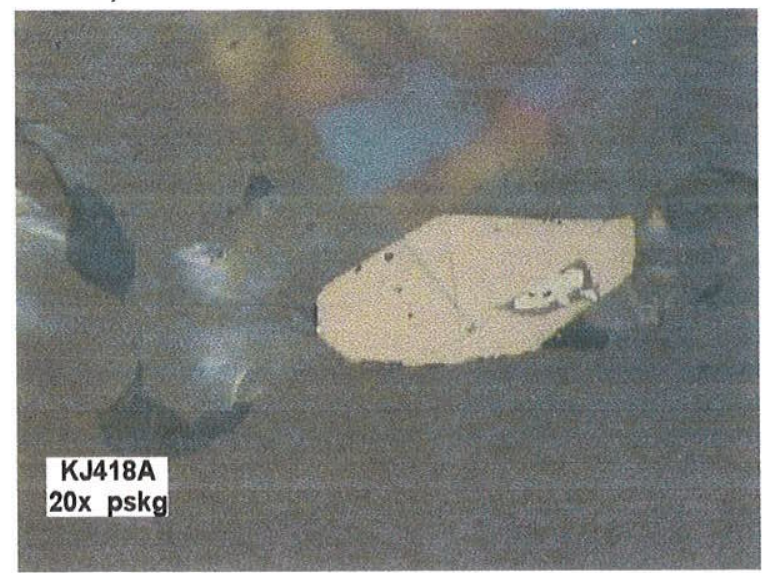

fot.43)

fot.44)
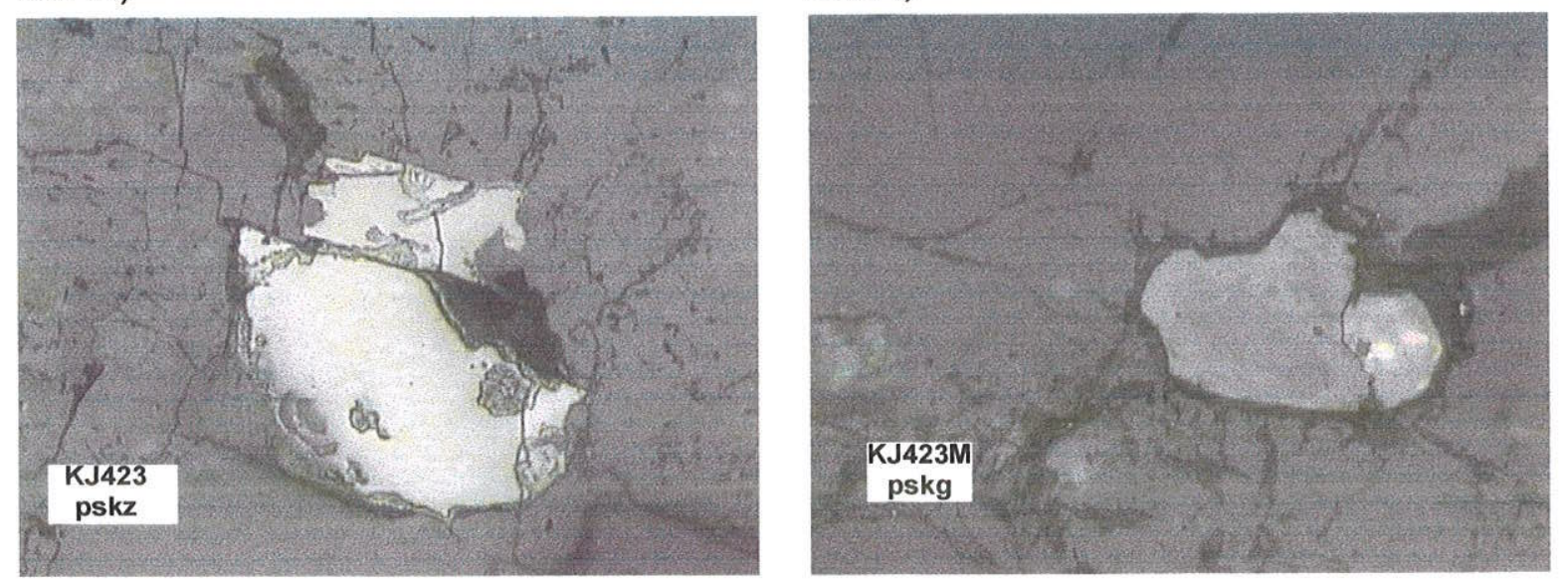

Prancha 8) Fotomicrografias 
A granada ocorre em cristais milimétricos $(1-2 \mathrm{~mm})$ subédricos, fraturados e com contatos irregulares com biotita (fot.48.), textura poiquiloblástica, com inclusões de quartzo, biotita e opacos.

Os minerais acessórios são: sillimanita anédrica a subédrica (fot.49.); epidoto em cristais anédricos; zircão e monazita em cristais arredondados a subédricos e traços de apatita acicular.

Os óxidos identificados ocorrem em cristais subédricos a anédricos associados à biotita, orientados segundo a foliação principal da rocha e por vezes inclusos e nas fraturas de biotita e granada e são: magnetita, hematita e ilmenita intercrescidos (fot 50 .).

Os sulfetos identificados ocorrem subédricos a anédricos, arredondados, dispersos ou associados aos minerais ferromagnesianos e são: calcopirita associada a pirrotita e bastante alterada (fot.51.), pirrotita e bornita.

As lentes de anfibolito presentes são constituídas por hornblenda, plagioclásio, biotita, quartzo e minerais opacos.

\subsection{Gnaisse Eugenópolis}

Esta unidade foi primeiramente caracterizada por Rosier (1965, apud Machado Filho et al. 1983) e depois definida por Machado Filho et al. (1983), como uma unidade litológica constituída por migmatitos, biotita gnaisses e biotita-muscovita xistos, ricos em pegmatitos.

Brandalise et al. (1976) incluíram os gnaisses da "Faixa Eugenópolis-Caparaó" de Rosier (op cit.) na Associação Paraíba do Sul. O DRM/RJ (1981), em mapeamento de detalhe na região nordeste do RJ, separou estas litologias novamente, conforme a caracterização inicial de Rosier (op cit.), usando o termo "Unidade Eugenópolis".

Machado Filho et al. (1983) associou o conceito de Rosier (op cit.) com o de DRM/RJ (op cit.), substituindo o termo "Unidade Eugenópolis" por Gnaisse Eugenópolis.

Afloramentos deste gnaisse ocorrem no setor norte da área do presente estudo e, as litologias estão descritas a seguir.

\section{(gneu) - biotita-muscovita gnaisses}

Esta unidade está representada na área por biotitammuscovita gnaisse milonitizado e migmatítico. Este gnaisse ocorre em contato com granitóides da Suite Intrusiva Espírito Santo à oeste e, sotoposto a gnaisses granulíticos do Complexo Juiz de Fora, por contato tectônico, à leste (ponto KJ417).

As rochas são finamente bandadas, acinzentadas, textura granoblástica e granolepidoblástica, e granulação média a grossa. 


\section{Prancha 9}

Foto 45) afloramento $\mathrm{KJ} 387$, lâmina $\mathrm{KJ} 387 \mathrm{t}$ - granada granulito; textura típica granolepidoblástica, foliação principal gerada pela biotita, granada no plano de foliação.

Foto 46) afloramento KJ387, lâmina KJ387c - biotita hornblenda- granada gnaisse; crescimento de agregados de biotita e hornblenda acompanhando a foliação principal da rocha.

Foto 47) afloramento KJ384, lâmina KJ384b - biotita- hornblenda- gnaisse; rocha em contato com o litotipo anterior, mas sem ortopiroxênio. Cristal de anfibólio cinza-esverdeado apresentando cristais de biotita de segunda geração cristalizando nas suas fraturas e bordas e, minerais opacos de primeira (magnetita inclusa) e segunda (opaco entre os cristais de biotita) geração associados.

Foto 48) afloramento KJ446, lâmina KJ446b2 - granada- biotita gnaisse; granada rosada, fraturada e corroída nas bordas, sendo substituída por biotita; textura poiquiloblástica evidenciada pelas inclusões de minerais opacos biotita e quartzo nas fraturas dos cristais de granada.

Foto 49) afloramento KJ394, lâmina KJ394s - biotita- hornblenda- sillimanita gnaisse; cristais de sillimanita associados a biotita e minerais opacos, em matriz de quartzo, felsdpato e plagioclásio.

Foto 50) afloramento $\mathrm{KJ} 420$, seção polida $\mathrm{KJ} 420$ - granitóide porfirítico migmatizado; magnetita (em cristal maior cinzam azulado) com exsoluçöes de hematita (cinza rosada) e cristais menores cinza azulados, ilmenita com lamelas de magnetita em cristais cinzentos inclusos na magnetita e nas bordas e em ripas alinhadas diminutas no interior do cristal de magnetita, 10x.

Foto 51) afloramento $\mathrm{KJ413}$, seção polida KJ4133 - hornblenda- biotita gnaisse; calcopirita (amarelo forte, levemente zonado), e alteração de sulfeto no centro e borda do cristal, $20 x$.

Foto 52) afloramento KJ417, lâmina KJ4173b - biotita- hornblenda gnaisse com muscovita; cristal subédrico de hornblenda associado a minerais opacos subédricos, plagioclásio, biotita e quartzo. 


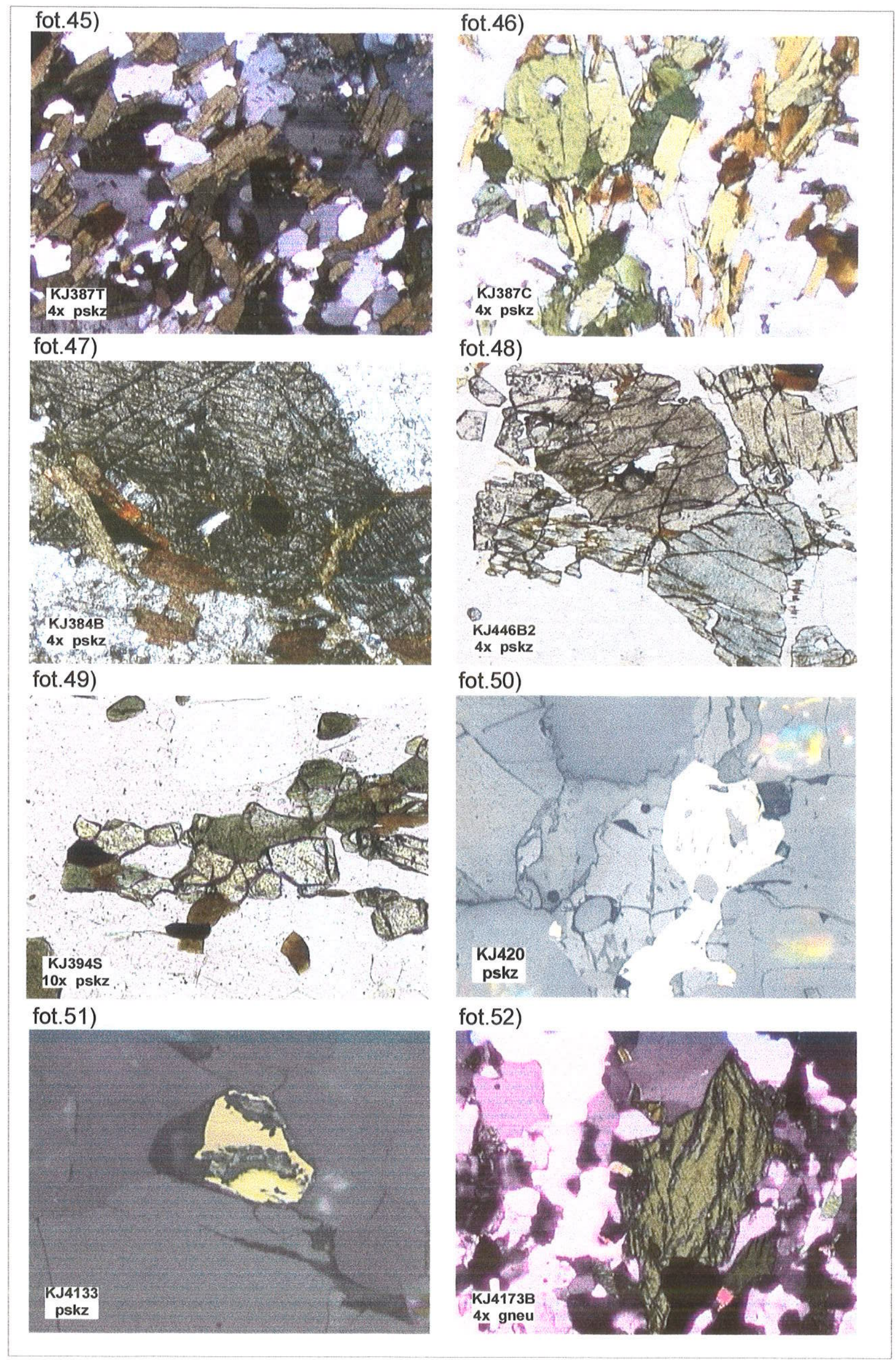

Prancha 9) Fotomicrografias 
Apresentam bandas félsicas quartzo- feldspáticas e bandas máficas com biotita orientada segundo a foliação principal, em rochas migmatíticas com estrutura nebulítica.

A composição mineralógica consiste de feldspato alcalino; plagioclásio (andesina) anédrico a subédrico com inclusões de biotita; quartzo em grãos discóides, associado ou incluso no plagioclásio; anfibólio (fot.52.) em cristais subédricos, associados à biotita; biotita em cristais subédricos, com pleocroísmo pardo-claro a castanho; muscovita subédrica, escassa. Os minerais acessórios são titanita, zircão, apatita e minerais opacos subédricos, representados por magnetita e hematita intercrescidos, goethita e sulfetos (fot.53.).

\subsection{Suite Intrusiva Espírito Santo}

Esta associação litológica foi proposta informalmente por Machado Filho et al. (1983), designando granitóides de carácter sin a pós tectônico ao Ciclo Brasiliano, similares aos que afloram na região da Serra dos Órgãos, no Rio de Janeiro. Ocorrem intrusivos nas litologias do Complexo Juiz de Fora e Gnaisse Eugenópolis, nos setores norte e sudeste da área estudada.

\section{- (ges) - granitóides}

Estes granitóides estão foliados, localmente migmatizados e milonitizados. Apresentam composição granítica a granodiorítica.

Os termos milonitizados afloram no setor sudeste da área, próximo à Santo Antônio de Pádua e termos migmatíticos afloram no setor norte, onde apresenta xenólitos de biotita-hornblenda gnaisse granulítico migmatizado do Complexo Juiz de Fora.

Apresentam composição granítica, granulação média a grossa, coloração rosada a cinza-claro, textura porfirítica, com megacristais de feldspato alcalino orientados, enclaves máficos, diques de microgranito de composição sienogranítica e veios de quartzo (fot.36.).

Sua composição mineralógica consiste de: feldspato alcalino (ortoclásio e subordinadamente microclínio) em megacristais de 1 a $5 \mathrm{~cm}$, frequentemente orientados (marcando fluxo magmático), quartzo em cristais anédricos, límpidos, plagioclásio subédrico a anédrico, associado à biotita, biotita com pleocroismo amarelo escuro a castanho-avermelhado, associada a hornblenda, anfibólio (hornblenda) com pleocroismo verde escuro a castanho. Os minerais acessórios são: apatita, titanita, zircão euédrico e minerais opacos, representados por: magnetita (fot.54.), ilmenita e hematita intercrescidos (fot.57.), associados com hormblenda e biotita quando secundários. Os sulfetos são calcopirita e pirita (fot.55; fot.56.). 


\section{Prancha 10}

Foto 53) afloramento KJ417, seção polida KJ4173d - biotita-granada gnaisse; exsoluções de hematita e magnetita, bordas de alteração com bornita (azul claro), goethita (cinza azulado claro com tintas rosadas), calcopirita (amarelo claro) na borda inferior esquerda, imersa em goethita e em contato com ferro (vindo da alteração da bornita), 20x.

Foto 54) afloramento $\mathrm{KJ} 430$, seção polida $\mathrm{KJ} 430$ - granito milonitizado; magnetita com exsoluções de ilmenita em cristais cinza azulados menores, rodeados por óxidos de alteração, bornita (rosado) e calcopirita (amarelo claro), no cristal maior, covelina em cristal azulado (canto superior direito), 20x.

Foto 55) afloramento $\mathrm{KJ415}$, seção polida $\mathrm{KJ} 415 \mathrm{c}$ - granito foliado (em contato com granada gnaise); pirita (amarelo forte) calcopirita (amarelo pálido no centro), bornita (rosa-azulado) e alterações dos sulfetos nas bordas e contatos com o silicato.

Foto 56) afloramento KJ415, seção polida KJ4151 - granito foliado (em contato com granada gnaisse); pirita (amarelo forte) euédrica, alterada no bordo direito, $20 \mathrm{x}$.

Foto 57) afloramento $\mathrm{KJ} 420$, seção polida $\mathrm{KJ} 420 \mathrm{~h}$ - granito (em contato com biotita- hornblenda- granada gnaisse); hematita (cinza claro) no centro de cristal zonado e alterado, ilmenita e calcopirita (amarelo) nas bordas, textura de reação nos bordos do cristal por migração do ferro, $20 x$.

Foto 58) afloramento KJ384, lâmina KJ384d - granada granulito; ortopiroxênio em cristal típico deste litotipo, óxidos e biotita nas fraturas.

Foto 59) afloramento KJ390, lâmina KJ390f - granada granulito; porfiroblasto de hornblenda cristalizado sobre a granada, associado a cristais de magnetita nas bordase como inclusão.

Foto 60) afloramento $\mathrm{KJ} 385$, lâmina $\mathrm{KJ} 385 \mathrm{c} 4$ - biotita granada gnaisse granulítico; formação de ortopiroxênio seguindo a direção do fraturamento em granada, presença de óxidos nas fraturas da granada e biotita nas bordas e fraturas. 

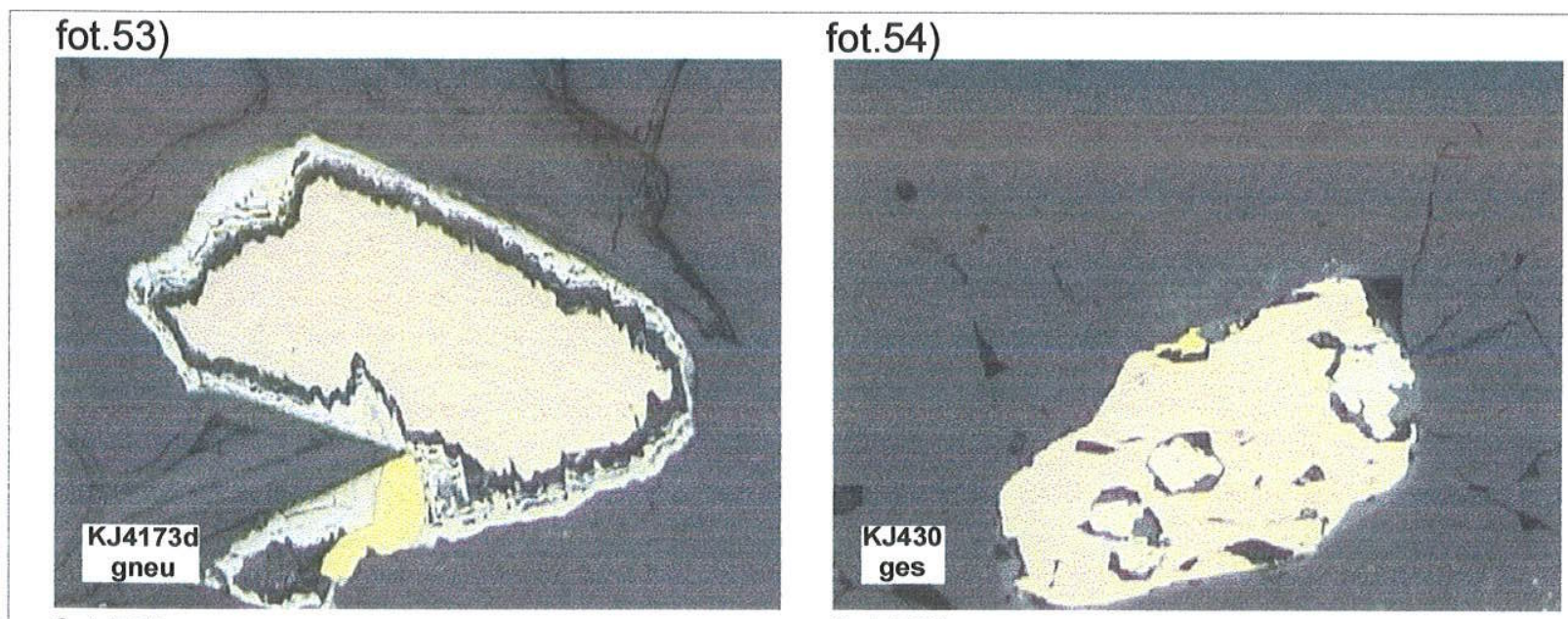

\section{fot.55)}

fot.56)

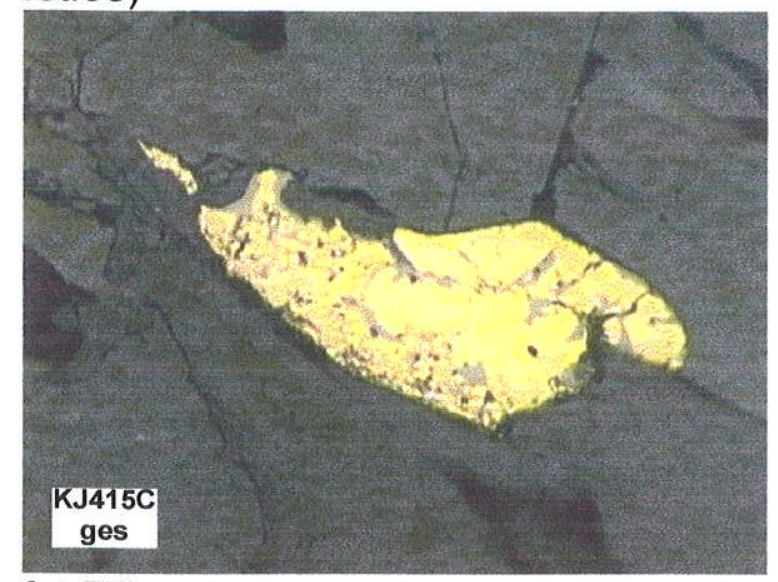

fot.57)

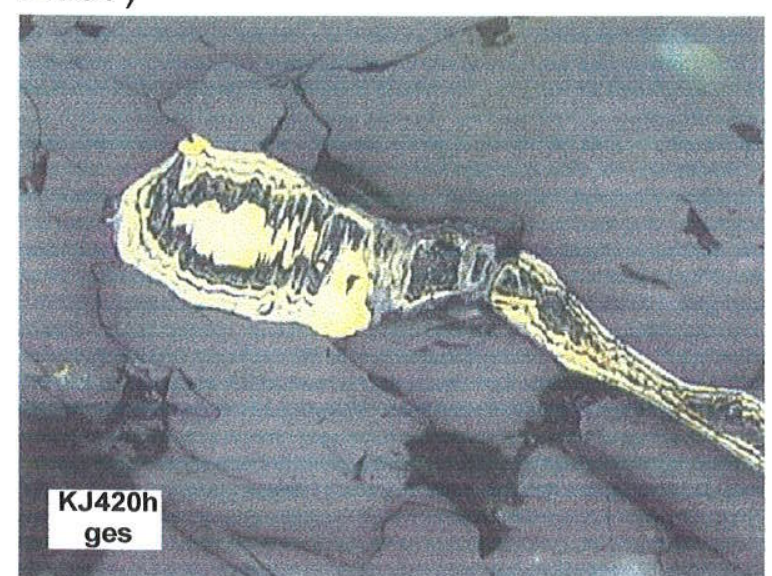

fot.59)
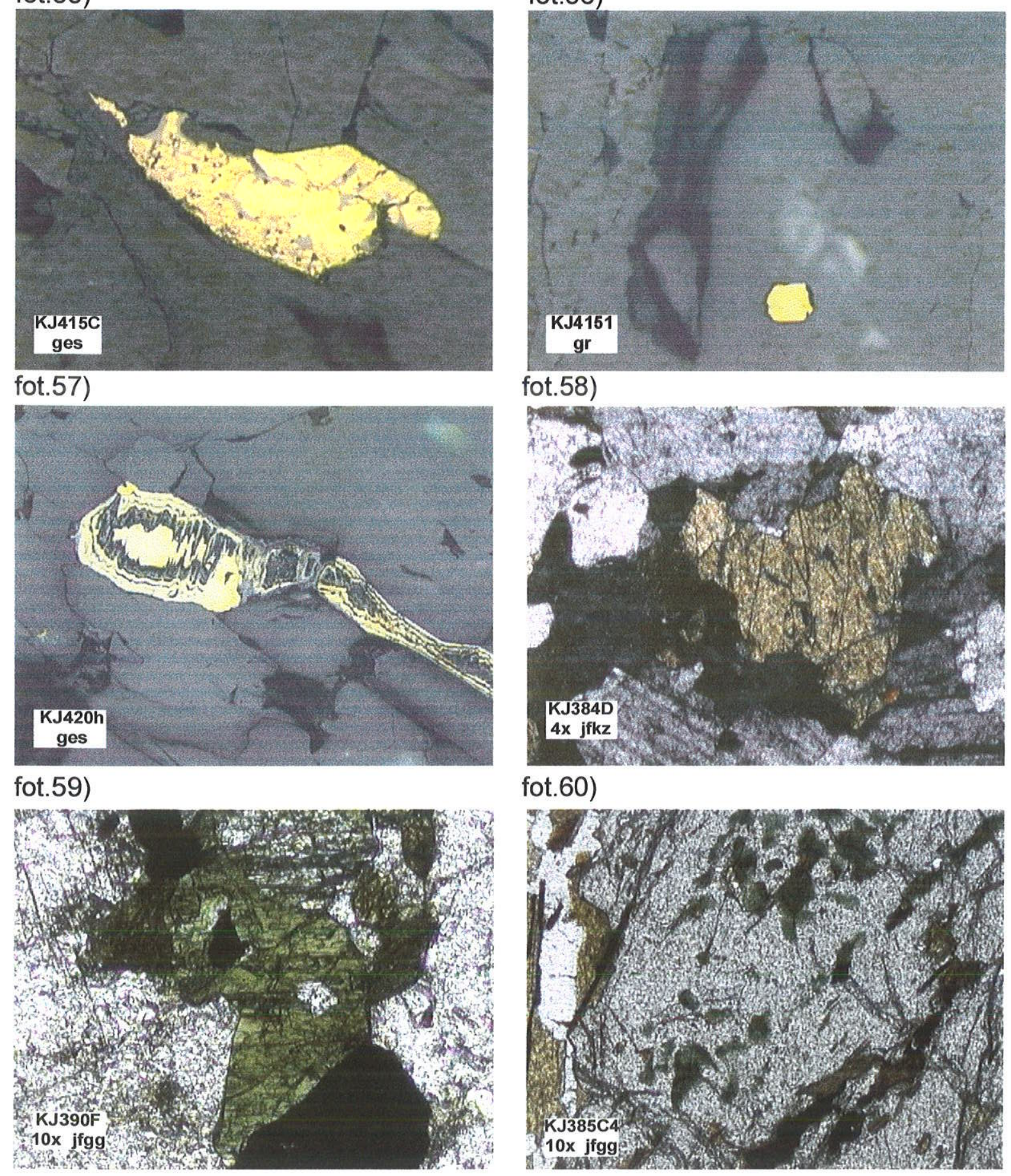

\section{fot.60)}

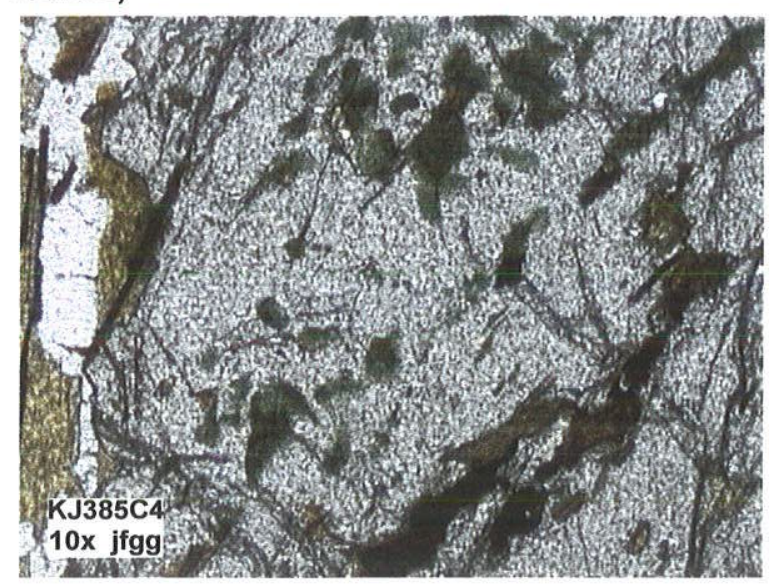


Veios dobrados de microgranito fino, rosado, de 10 a $50 \mathrm{~cm}$ de largura, injetam toda a área e principalmente os migmatitos e granitos. Estes veios muitas vezes apresentam direção nordeste, coincidente com o trend preferencial das estruturas da área e da Zona de Cisalhamento Além Paraíba.

As principais características petrográficas das litologias da área estão resumidas em (tab.3.1.) e, considerações sobre a petrografia acima descrita, aliadas e comparadas a dados obtidos na literatura constam no ítem exposto a seguir.

\subsection{Interpretação e discussão dos dados}

Os dados petrográficos obtidos no presente trabalho permitiram a individualização e caracterização das litologias aflorantes, predominantemente rochas granulíticas, de composição enderbítica a charnockítica e gnaisses, em fácies anfibolito alto, de composição granodiorítica a tonalítica, geradas sob condições de metamorfismo progressivo de alta temperatura e baixa pressão, reequilibradas posteriormente sob temperaturas mais baixas e, subordinadamente, migmatitos e rochas granitóides.

As rochas intermediárias e básicas, pertencentes ao Complexo Juiz de Fora, constituem o embasamento, representado por gnaisses granulíticos de origem ígnea e sedimentar, granulitos e charnockitos, das rochas supracrustais intermediárias, representadas por orto e paragnaisses pertencentes ao Complexo Paraíba do Sul e Gnaisse Eugenópolis.

Os migmatitos afloram próximos à falhamentos de empurrão e/ou próximos à intrusões graníticas. Gnaisses granuiliticos ocorrem migmatizados, sugerindo, neste caso, que a granulitização foi anterior à migmatização.

Locaimente ocorrem migmatitos, com paleossoma granulítico e neossoma quartzo feldspático, próximos a charnockitos e granulitos, na porção central e noroeste da área, ambos associados a falhamento transcorrente, sugerindo origem metamórfica para os charnockitos ali presentes, cujo contato com as litologias circundantes não ficou definido em campo.

As litologias aflorantes ocorrem dispostas em blocos, alongados e descontínuos, na direção N-NE, localmente truncados por estruturas E-W. Os contatos acontecem por falhamentos de empurrão, de baixo ângulo de mergulho e cujo traço mostra direções NE, N-NE, N-NW, predominantemente nos setores oeste, norte, central e sul da área estudada $e$, através de falhamentos direcionais NE de alto ângulo, nos setores sudeste e sul sudoeste da área, correlatos à Zona de Cisalhamento Além Paraíba. 


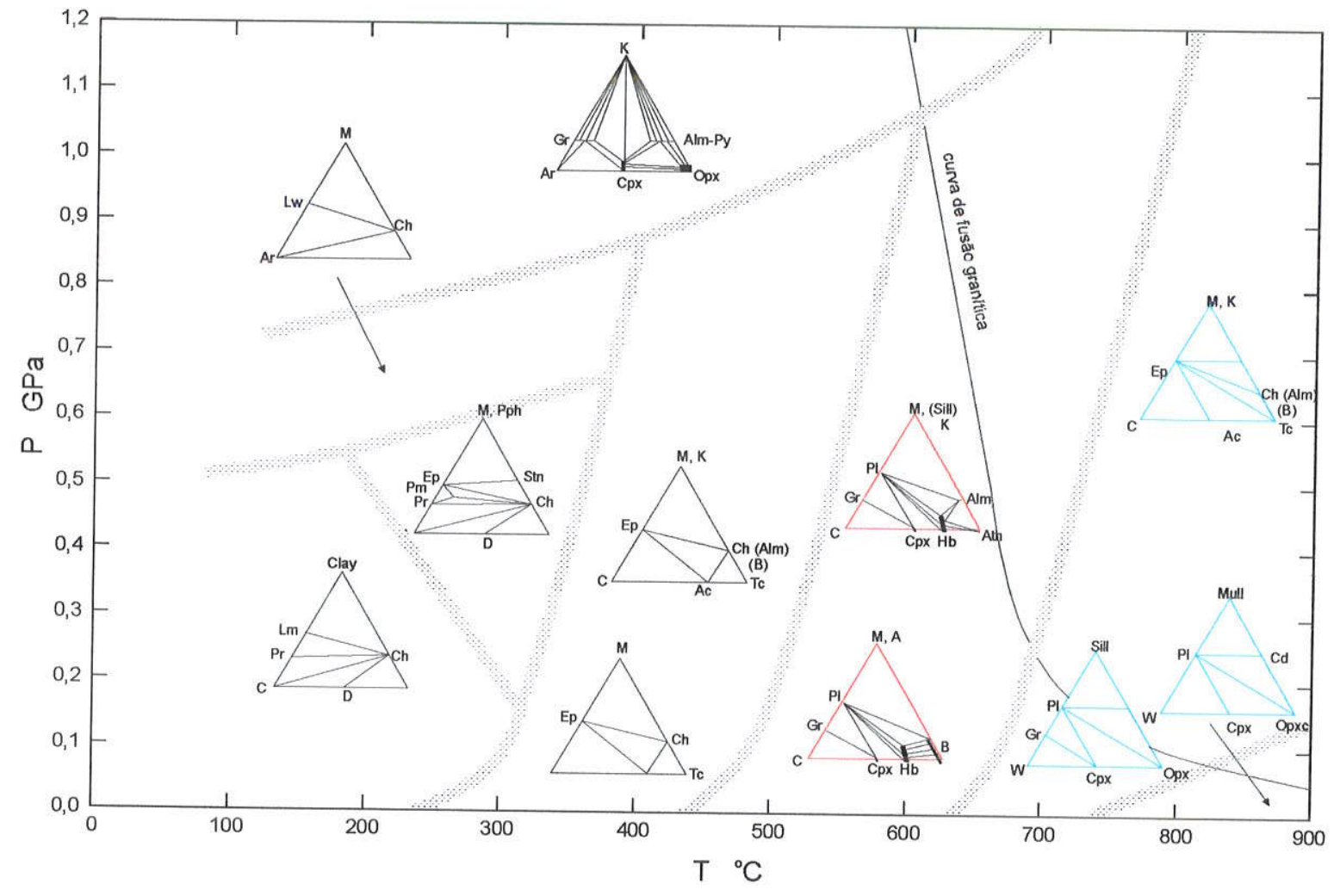

Fig. 3.1. Diagrama PxT com as fácies metamórficas e diagramas ACF das assembléias mineralógicas. Em azul, os diagramas da fácies granulito e em vermelho, os diagrams da fácies anfibolito, onde plotam as litologias que afloram na área estudada.

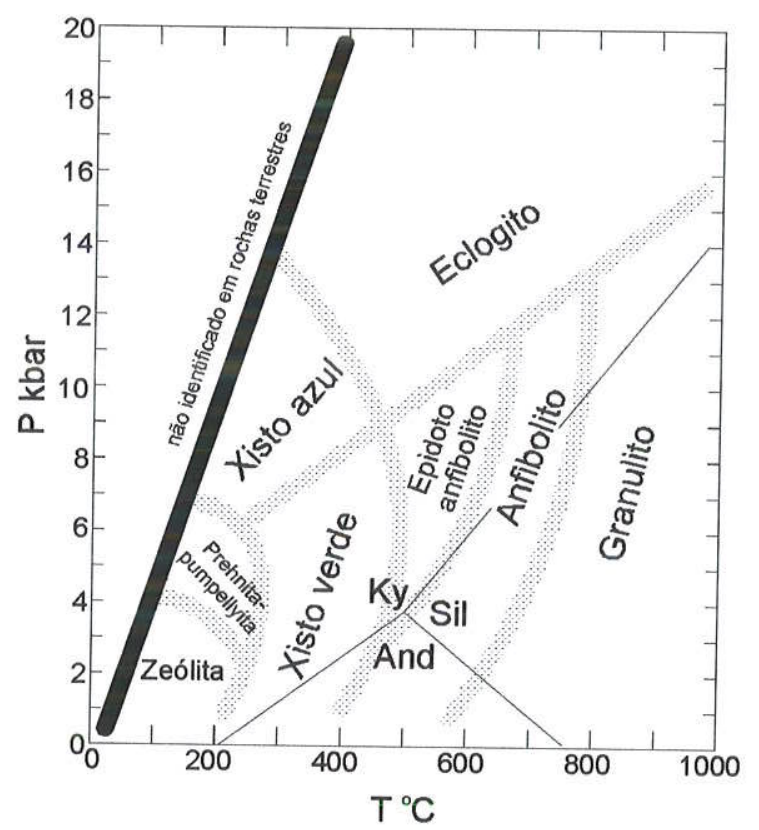

Fig. 3.2. Diagrama PxT mostrando as principais fácies metamórficas e o ponto triplo da alumina $\left(\mathrm{Al}_{2} \mathrm{SiO}_{5}\right)$, com os campos de estabilidade da cianita, andaluzita e sillimanita, no metamorfismo regional de rochas máficas depois de Holdaway (1971) apud Spear (1993). 
O metamorfismo retrógrado ocorre em vários pontos da área e, principalmente nas rochas da parte sudeste e sul - sudeste da área, onde ocorrem orto e paragnaisses do Complexo Paraíba do Sul em contato com paragnaisses granulíticos do Complexo Juiz de Fora, através de falhamentos direcionais relacionados aos efeitos da tectônica transpressiva que afetou a área. O soerguimento destas litologias favoreceu a percolação de fluidos, ao longo destes falhamentos promoveram a hidratação das paragêneses.

As rochas aflorantes nos setores sudeste e sul - sudeste foram fortemente recristalizadas e afetadas por deformação dúctil, indicada pelo formato lobado e serrilhado dos grãos, feldspatos estirados, subgrãos de quartzo, cordões de quartzo recristalizado ao redor de minerais e ribbons.

As litologias do Complexo Juiz de Fora, predominantes na área, apresentaram paragênese anidra, composta de ortopiroxênio + - clinopiroxênio + plagioclásio, por vezes substituída por anfibólio + quartzo e óxidos, nas rochas de composição enderbítica e, nas rochas charno-enderbíticas e charnockiticas, a paragênese anidra, composta de ortopiroxênio + - (granada) + feldspato potássico + - quartzo, mostrou substituição parcial por biotita +- (sillimanita) + quartzo e óxidos. Pela composição predominantemente enderbítica e paragênese característica, estas litologias podem ser expressas no diagrama de rochas básicas (fig. 3.1.).

Evidências de metamorfismo retrógrado na fácies anfibolito ocorrem com frequência na área estudada. As litologias granulíticas foram parcialmente transformadas em hornblenda- biotita gnaisses bandados, com resquícios da assembléia de maior temperatura.

Nos ortognaisses granulíticos enderbíticos (jfkg) e granulitos máficos (jfgg) temos a paragênese principal composta de plagioclásio + ortopiroxênio + clinopiroxênio ( +feldspato potássico), magnetita, ilmenita, com ou sem quartzo. Quando ocorre anfibólio (hornblenda), este não está em equilíbrio com a paragênese principal, mas substituindo o piroxênio.

Nos gnaisses granuliticos e granulitos, as feições de reação como coroas com cristais de anfibólio em torno de cristais de piroxênio (fot.15.) indicam decréscimo nas condições de equilíbrio de pressão e temperatura, com diminuição de pressão, possivelmente por descompressão.

Feições do tipo granada com ortopiroxênio e plagioclásio (fot.60.), (fig.A.12.) e grãos de hornblenda formados ao redor de cristais de piroxênio (fot.17.), de cristais de plagioclásio, bem como ilmenita associada à titanita, indicam reequilíbrio para condições de temperatura e pressão mais baixas. 
Tab. 3.1. Características petrográficas de litologias da área estudada

\begin{tabular}{|c|c|c|c|c|}
\hline & Litologia & Comp./Granulação & Estruturas / Texturas & Composição mineralógica \\
\hline \multirow{4}{*}{ PSKZ } & biot-hbl-grt gnaisse & diorítica/fina a média & granob. granolep. & pla, biot, alm, fK, qzo, sill, opac, zr, ap \\
\hline & gr-biot gnaisse & granod./fina a média & milonitica / granolep. & pla, fK, qzo, biot, grt, opac, pirrot, cpir, born, mon, ap \\
\hline & grt-hbl-biot-sill gnaisse & granod./média & migmatítica / granonematob. & pla, $\mathrm{fK}_{\text {, }} \mathrm{qzo}$, grt, hbl, bjot, sill, opac, tit, mon \\
\hline & hbl- biot- sill gnaisse milonítico & granod./fina & milonítica / granonem. & pla, fK, qzo, hbl, biot, sill, opac, tit, mon \\
\hline \multirow{6}{*}{ PSKG } & biot-hbl gnaisse & granítica/média & milonítica / granob. & fK, pla, qzo, hbl, biot, opac, $\mathrm{zr}$, ap \\
\hline & biot-grt gnaisse & granítica/média & migmatítica / granolep. & fK, pla, qzo, olig, mic, biot, grt, sill, opac, goet, hem, epi, zr, ap \\
\hline & biot-hbl gnaisse & granod./média & granob. granonem granop. & pla, fk, qzo, hbl, biot, opac, cpir, zr, ap \\
\hline & hbl-biot gnaisse & granod./fina a média & granob. porfirob. & pla, fK (mic), gzo, biot, hbl, opac, cpir, zr, tit, ap \\
\hline & mic-hbl-biot gnaisse & sienog./média & granopor. & mic, pla, qzo, biot, hbl, opac, mag, ilm, born, esp, zr, ap \\
\hline & biot-grt gnaisse & monzogr./média & nematob.granob.granolep. & pla, mic, qzo, opx, biot, grt, opac, zr, ap, mon, tit \\
\hline \multirow{9}{*}{ JFKZ } & $\frac{\text { grt-hbl-biot gnaisse granulítico }}{\text { biot-grt gnaisse aranulitico }}$ & charnoend./média & nematob.granob.granolep. & pla, fk, qzo, biot, opx, grt, opac, zr, ap, carb \\
\hline & $\begin{array}{l}\text { biot-grt gnaisse granulítico } \\
\text { biot-grt gnaisse granulitico }\end{array}$ & charnoend./média & granolep. porfirob. & pla, fK, qzo, biot, opx, grt, sill, opac, zr, tit, ap \\
\hline & $\frac{\text { biot-grt gnaisse granulitico }}{\text { grt granulito }}$ & charnoend./média & granob. granolep. & pla, fK, qzo, biot, opx, grt, opac, $\mathrm{zr}_{\text {, tit, mon }}$ \\
\hline & $\frac{\text { grt granulito }}{\text { grt-biot-pla gnaisse granulítico }}$ & mang./fina a média & granob granoporf. & pla, fK, opx, biot, grt, qzo, zr, opac, tit, mon \\
\hline & $\begin{array}{l}\text { gint-ojot-pla gnalsse granulitico } \\
\text { biot-hbl-grt gnaisse granulítico }\end{array}$ & charnoend./média & granob. granolep. & pla, fK, qzo, biot, grt, opx, opac, zr, ap, mon, tit \\
\hline & biot-grt gnaisse granulítico & $\frac{\text { mang./fina a média }}{\text { charnock./média }}$ & milonítica / granob granolep. & pla, fK, biot, grt, opx, qzo, sill, opac, $\mathrm{zr}$, ap \\
\hline & biot-hbl-grt gnaisse granulítico & $\frac{\text { charnock./média }}{\text { enderb./fina }}$ & migmat. / granolep. porf. & qzo, pla, mic, biot, grt, sill, opx, mag, hem, bor, goet, cpir, epi, zr, ap \\
\hline & grt granulito & $\frac{\text { enderb./fina }}{\text { charnoend./fina }}$ & granob. porfirob. & pla, fK, qzo, opx, hbl, opac, mag, ilm, hem, cpir, pirrot, born, $\mathrm{zr}$, ap \\
\hline & grt gnaisse granulítico & $\begin{array}{l}\text { charnoend./fina } \\
\text { enderbitica/fina }\end{array}$ & granob. & pla, fK (ort), qzo, biot, grt, opx, opac, zr, tit, mon \\
\hline \multirow{4}{*}{ JFKG } & gnaisse granulitico & $\begin{array}{l}\text { enderbitica/fina } \\
\text { charnoend./média }\end{array}$ & granob. granolep granop. & pla, opx, grt, biot, hbl, fK, qzo, opac, pirrot, cpir, ilm, tit, mon, ap \\
\hline & biot -hb gnaisse granulítico & $\begin{array}{l}\text { charnoend./média } \\
\text { enderbitica/média }\end{array}$ & granonem.granolep.granob. & pla, opx, biot, anf, cpx, qzo, opac, zr, tit, mon, \\
\hline & hb-biot gnaisse granulítico & charnoend./média & $\begin{array}{l}\text { granonem.granolep. } \\
\text { granonem granolep }\end{array}$ & pla, fK, opx, biot, qzo, hbl, opac, mag, hem, zr, ap, tit \\
\hline & biot-grt gnaisse granulítico & charnoend./média & $\begin{array}{c}\text { granonem granolep. } \\
\text { granob. granolep. }\end{array}$ & pla, fK, opx, biot, anf, qzo, mag, ilm, pirrot, cpir, born, cov, zr, ap \\
\hline \multirow{2}{*}{ JFGG } & charnockito & charnock./grossa & $\frac{\text { granob. granolep. }}{\text { maciça / granob. }}$ & pla, fK, opx, grt, biot, qzo, opac, $\mathrm{zr}$, tit, mon \\
\hline & granulito & enderbítica/fina & $\frac{\text { maciça / granob. }}{\text { maciça / granob. }}$ & $\mathrm{fK}$, pla, qzo, opx, biot, cpx, zr, tit, mon, mag, opac \\
\hline \multirow{2}{*}{ GES } & granito porf. & charnock/grossa & $\frac{\text { maciça / granob. }}{\text { maciça / porfir. }}$ & pla, opx, biot, fK, cpx, qzo, opac, tit, mon, ap \\
\hline & granitóide porf. migmat. & granit/grossa & $\frac{\text { maciça / porfir. }}{\text { porfirítica }}$ & fK (ort), pla, qzo, cpx, biot, hbl, opac, zr, tit, mon, ap \\
\hline \multirow{2}{*}{ GNEU } & biot-hbl gnaisse musc & granod./média & $\frac{\text { porfiritica }}{\text { granob. granonem. granop. }}$ & fK, pla, qzo, biot, hbl, opac, mag, hem, ilm, zr, ap \\
\hline & hbl-biot gnaisse pegmatítico & granod./média & $\frac{\text { granob. granonem. granop. }}{\text { foliada / granoporf }}$ & pla, fk, qzo, hbl, biot, musc, opac, zr, ap \\
\hline
\end{tabular}


A presença de ortopiroxênio e plagioclásio é característica nas lentes de granulitos e gnaisses granulíticos enderbíticos do Complexo Juiz de Fora, que ocorrem frequentemente intercalados com paragnaisses félsicos com granada, mas sem piroxênio, do Complexo Paraíba do Sul (compare fot.47. com fot.58).

A formação de hornblenda e biotita pela substituição parcial de cristais de piroxênio é uma feição observada com frequência nas rochas granulíticas da área e indica a hidratação da assembléia mineral destas rochas, ao longo dos contatos entre as superfícies de empurrão ou falhas direcionais.

Os porfiroblastos de hornblenda são escassos, associados aos cristais de biotita e minerais opacos, ocorrendo nas bandas máficas dos ortognaisses granulíticos básicos (jfkg), como mineral primário preservado, algumas vezes com óxidos nas fraturas.

Nas rochas da parte sudeste da área, onde ocorrem orto (pskg) e paragnaisses (pskz) do Complexo Paraíba do Sul em contato com paragnaisses granulíticos com granada (jfkz) do Complexo Juiz de Fora, verificamos a presença de uma assembléia mineral representada por porfiroblastos de piroxênio, com óxidos nas fraturas e clivagens e, também de cristais de plagioclásio, quartzo e hornblenda primária, nos gnaisses granuliticos.

Esta mesma assembléia mineral, com acréscimo de clinopiroxênio, com os cristais de piroxênio sendo substituídos por anfibólio e biotita e, com os cristais de anfibólio associados ao crescimento de biotita e opacos nas fraturas e bordas, ocorre preservada como porfiroblastos, acusando a atuação do metamorfismo retrógrado das litologias granulíticas. A presença de cordierita indica alta temperatura e pressão média, ou descompressão sob temperatura constante.

Outras feições indicativas de metamorfismo retrógrado ocorrem localmente, como cristais de quartzo e lamelas de granada sobre porfiroblastos de piroxênio (fot.58.; fot. 59.) (fig.A.20.). A reação referente ao desaparecimento do piroxênio é: piroxênio + plagioclásio = quartzo + granada.

A formação de ortopiroxênio, biotita, plagioclásio e opacos nas fraturas e bordas da granada, sem presença de clinopiroxênio indica condições de pressão mais baixas em gnaisses granatíferos granuliticos do Complexo Juiz de Fora, segundo a reação grt+qzo=opx+pla (fot.60.), (fig.A.12.).

Nos setores central, oeste e norte da área, o metamorfismo retrógrado ocorreu provavelmente durante o soerguimento das litologias granulíticas, promovido durante a tectônica tangencial que gerou os empurrões, predominantes nestes setores.

Gnaisses granulíticos ocorrem migmatizados, associados aos falhamentos de empurrão, próximos à intrusões graníticas e também próximos a falhamentos direcionais 
NW. Migmatitos, nos setores central e norte, apresentaram estruturas dobradas para NW. Localmente ocorrem migmatitos, com melanossoma granulítico e leucossoma quartzo feldspático, próximos a charnockitos, e granulitos, na porção noroeste da área (pontos 422, 382 e 383, fig.4.1.), em área de falhamento direcional, o que sugere a associação dos charnockitos com os granulitos ali presentes.

As litologias do Complexo Paraíba do Sul, aflorantes no limite oriental da área, representadas por granada gnaisses e sillimanita- granada gnaisses, com paragêneses evidenciando alta temperatura apresentaram paragênese metamórfica indicativa de fácies anfibolito alto (fig.3.1.), acima da segunda isógrada da sillimanita (fig.3.2.) (fot.49.), composta de anfibólio + biotita + plagioclásio + _ (granada) e sillimanita, por vezes reequilibrada para anfibólio + biotita e óxidos.

Os paragnaisses com sillimanita e feldspato alcalino pertítico ocorrem esparsos (fot. 47 ; fot.49.) (fig.A.16.) e a assembléia mineral composta de granada + biotita + plagioclásio + feldspato potássico + sillimanita + cordierita + ilmenita é típica de metapelitos de alta temperatura, acima da segunda isógrada da sillimanita (fig. 3.2.), mostrando condições compatíveis com a migmatização verificada em alguns pontos, próxima à granitos aflorantes no setor sudeste da área.

Nos biotita-hornblenda gnaisses há evidências de diminuição da temperatura, indicado pela formação de biotita parcialmente substituindo o anfibólio, associada a opacos e quartzo (fot.47.) (fig.A.11.) e o feldspato potássico apresenta como fase predominante o microclínio (fot.40.).

Em muitas amostras de granadambiotita gnaises, porfiroblastos de granada parecem formados a partir do consumo de cristais de biotita, minerais opacos e quartzo, indicando metamorfismo progressivo.

Por outro lado, alguns cristais de granada também ocorrem, em biotita-granada gnaisses do setor sudeste da área, parcialmente substituída em suas bordas e em fraturas por biotita, indicando reequilibrio em temperaturas mais baixas, com rehidratação associada, da granada e da matriz quartzo feldspática.

Reequilíbrio, com maior pressão de água poderia promover a cristalização dos agregados de biotita (fot.31.) e hornblenda presentes (fot.46.). A granada cristalizou sobre estes agregados (fot.46.) associada aos cristais de biotita e minerais opacos.

As condições sugeridas pela assembléia mineral dos paragnaisses com granada do Complexo Paraíba do Sul ( $p s k z$ ) condizem com a assembléia mineral dos paragnaisses com biotita e hornblenda (pskg) do mesmo Complexo e com a paragênese dos gnaisses granulíticos com biotita e hornblenda e migmatitos do Complexo Juiz de Fora (jfkg), com 
os quais estão intercalados.

O reequilíbrio das paragêneses sob condições de temperatura e pressão mais baixas pode ser devido à exumação destas rochas devida à tectônica transpressional, associado à percolação de fluidos nos planos de falhamentos direcionais presentes nos setores leste, sudeste e sul - sudeste da área, onde afloram as litologias do Complexo Paraíba do Sul.

No setor sudeste e sul - sudeste da área, o metamonfismo retrógrado estaria relacionado a um soerguimento diferencial de rochas de diferentes niveis crustais, ao longo de falhas transcorrentes, durante a tectônica direcional (strike-slip associadas a flower structure) que também produziu a forte milonitização neste setor. Esta milonitização favoreceria, a percolação dos fluidos causadores da hidratação da paragênese.

A evolução metamórfica da área, sugerida pelos dados petrográficos obtidos neste trabalho, implica na presença de rochas orto e paraderivadas, que foram metamorfizadas em fácies anfibolito e granulito, durante um evento metamórfico (M1), gerando foliação gnáissica regional. Posteriormente, estas rochas foram afetadas por um evento metamórfico retrógrado (M2) que favoreceu o reequilíbrio da assembléia mineralógica destas rochas para condições de temperatura e pressão menos elevadas.

Evidências geocronológicas apresentadas em Cordani et al. (1968b, 1973, 1973b, 1979) e Delhal et al. (1969) indicaram idade transamazônica (aprox. 2,0 G.a.) para as rochas dos Complexos Paraíba do Sul e Juiz de Fora, idade brasiliana (600 - 540 M.a.), incluindo datação K/Ar em rocha da área de Santo Antônio de Pádua) para o evento que retrabalhou estas rochas e gerou granitos sintectônicos e, idade tardi a pós-brasiliana (500 - 470 M.a.) para um evento que gerou granitos pós - tectônicos. O metamorfismo nas fácies granulito e anfibolito foi colocado como anterior à milonitização brasiliana.

Estas evidências são concordantes com a verificação de duas fases metamórficas regionais, uma responsável pela formação das rochas granulíticas e gnáissicas da área e outra responsável pelo retrometamorfismo destas rochas, indicadas pela análise dos dados petrográficos obtidos nesta dissertação.

Oliveira (1980, 1981, 1982, 1983) e Batista (1984) propuseram que as rochas dos Complexos Juiz de Fora e Paraíba do Sul, de idade primária arqueana, foram deformadas e recristalizadas, em ambiente de catazona, durante os Ciclos Transamazônico e Brasiliano, transformando charnockitos ígneos e rochas supracrustais em granulitos, gnaisses kinzigíticos e milonitos.

Oliveira $(1981,1982)$ apresentou dados indicando condições de temperatura entre 
$812-839^{\circ} \mathrm{C}$ e pressão entre $6-4 \mathrm{~Kb}$, (termômetro ortopiroxênio - clinopiroxênio em cristais de piroxênio) para o metamorfismo granulítico de gnaisses granulíticos afetados por tectônica transcorrente, concordantes com as assembéias mineralógicas e texturas verificadas pelos dados petrográficos apresentados nesta dissertação, para as rochas granulíticas pertencentes ao Complexo Juiz de Fora, durante o metamorfismo retrógrado (M2).

Siga Jr. et al. $(1982,1989)$ propôs a existência de um processo erosivo que removeu $20 \mathrm{Km}$ de crosta, ao longo do Sudeste brasileiro, desenvolvido em duas etapas, uma durante a orogênese brasiliana e outra durante o Meso - Cenozóico. A descompressão brasiliana é condizente com os dados petrográficos sugestivos de diminuição de pressão para os gnaisses granulíticos do Complexo Juiz de Fora.

lyer et al. (1987) obtiveram dados geocronológicos indicando duas gerações de rochas granulíticas na Faixa Ribeira, envolvendo o Complexo Juiz de Fora, estudado nesta dissertação. A primeira teria produzido complexos granulíticos entre 2,1 - 2,7 G.a. e, a segunda geração teria idade neoproterozóica, entre 620 - 570 M.a..

Egydio - Silva \& Mainprice (in press), Porcher (1997), Tupinambá \& Trouw (1995) e Correa Neto (1994) apresentaram dados petrográficos e microestruturais para gnaisses e granulitos milonitizados, próximos à area do presente trabalho, sugerindo que a deformação transcorrente ocorreu sob condições metamórficas da fácies granulito, em acordo com a segunda geração de rochas granulíticas, propostas por lyer et al. (op.cit.), durante o Ciclo Brasiliano.

Na presente dissertação, os dados petrográficos obtidos não evidenciaram se a transcorrência ocorreu sob fácies granulito ou simplesmente sob fácies anfibolito alto, seguida do pico do metamorfismo na fácies granulito.

Dayan e col. $(1989,1993,1994)$ consideraram o metamorfismo retrógrado, presente nas litologias granulíticas, originado pelo soerguimento e hidratação das rochas granulíticas, durante a deformação transcorrente, indicado pela cristalização progressiva de hornblenda e biotita sincinemáticos, sobre piroxênio.

A proposta desta dissertação para o metamorfismo da área, cujos dados petrográficos indicaram a presença de uma fase de deformação (D1), relacionada a metamorismo (M1), e um metamorfismo retrógrado (M2) afetando estas litologias, é condizente com a proposta de Dayan e col. (op.cit.), verificada pela similaridade das feições de reação. 
A evolução tectônica da região deste trabalho, segundo Porcher (1997), envolveu dois eventos principais, um evento tangencial (D1 + D2) acompanhado por metamorfismo progressivo regional (M1), e um evento transcorrente (D3) mais jovem, desenvolvido sob condições metamórficas retrógradas (M2).

Para as rochas relacionadas ao evento $\mathrm{D} 1+\mathrm{D} 2$, dados termobarométricos indicaram temperatura entre $807-877^{\circ} \mathrm{C}$ e pressão entre $6-6,7 \mathrm{~Kb}$ para $\mathrm{M} 1 \mathrm{e}$, para as rochas relacionadas ao evento $\mathrm{D} 3$, temperatura entre $734-743^{\circ} \mathrm{C}$ e pressão de $5,2 \mathrm{Kbar}$ para M2. Para Porcher (op.cit.), o metamorfismo (M1), relacionado ao evento tangencial (D1+D2) apresentou feições sugestivas de descompressão isotérmica e, o metamorfismo (M2), relacionado ao evento transcorrente (D3), apresentou dados condizentes com trajetória de resfriamento isobárico, ao final de D3, causado por relaxamento térmico devido a erosão.

A autora colocou a impossibilidade de datação relativa entre os eventos tangencial e direcional, devido à carência de dados geocronológicos mas, sugere, no caso de estes eventos terem se desenvolvido durante um mesmo ciclo orogênico, que seus resultados termobarométricos condizem com trajetórias $\mathrm{P}$ - $\mathrm{T}-\mathrm{t}$ de situações envolvendo espessamento crustal, possivelmente devido ao cavalgamento e também aos efeitos da transcorrência.

Os dados obtidos nesta dissertação, referentes às assembléias mineralógicas e texturas observadas nas litologias da área, são condizentes com as considerações apresentadas em Porcher (1997), para os eventos metamórficos progressivo e retrógrado. Entretanto, na presente dissertação, relacionamos um evento transpressivo (D1), que envolveu deformação tangencial associada à direcional, ao metamorfismo progressivo (M1) e, consideramos que o metamorfismo retrógrado (M2) foi concomitante e posterior ao final da deformação direcional gerada por D1. Seriam necessários dados geocronológicos para determinar a relação exata entre M1 e M2.

Considerando as altas temperaturas sugeridas pelas paragêneses verificadas durante o presente trabalho, o esclarecimento do quadro termocronológico da região necessita de métodos geocronológicos que apresentam temperatura de fechamento elevada, como U/Pb em zircão, granada, monazita e titanita e $\mathrm{Sm} / \mathrm{Nd}$ em granada e piroxênio. 


\section{Análise estrutural e cinemática}

Nos trabalhos de campo foram estudados 73 afloramentos, plotados no Mapa de Pontos (fig. 4.1.). As atitudes das medidas de estruturas planares e lineares, obtidas em campo, estão plotadas no mapa (fig.4.2.) e as coordenadas geográficas das atitudes médias da foliação e lineação magnéticas, representativas de cada afloramento, estão plotadas no mapa (fig.4.3.).

A partir da observação destes mapas foi verificada a existência setores com predominância de diferentes atitudes de foliação e lineação (fig.4.4.).

As litologias aftorantes nestes setores, associadas às estruturas ali observadas, estão representadas no Mapa Geológico (Anexo 3).

As atitudes de estruturas visiveis em campo, analisadas em conjunto com as atitudes obtidas pela ASM, (compare fig.4.2. e 4.3.) apresentou evidente similaridade e, permitiu considerar a fábrica magnética como normal, onde os eixos do elipsóide de susceptibilidade K1 e K3 são representativos da lineação magnética (K1) e do pólo da foliação magnética (K3), possibilitando o tratamento dos dados necessários para traçar o padrão de comportamento cinemático para a área e seus setores.

A fábrica planar predominante encontrada nos litotipos da área é o bandamento gnáissico, com dobras marcadas por bandas máficas, cujos planos axiais são paralelos à direção dos planos principais de foliação NE. A foliação milonítica predomina no setor sul.

A fábrica linear é dada por lineações de biotita, anfibólio e estiramento de feldspatos, com mergulhos variáveis, de baixo ângulo em gnaisses granatíferos e miloníticos no setor sul e de médio a alto ângulo nos demais setores da área.

A identificaçẩo dos minerais magnéticos presentes, nas amostras da área estudada neste trabalho, foi feita através de microscopia ótica de luz transmitida e refletida, utilizando lâminas delgadas e seções polidas, onde foram identificados magnetita, hematita rica em titânio, pirrotita e ilmenita como principais minerais magnéticos opacos e, biotita, anfibólio e piroxênio como silicatos magnéticos, indicando que a fábrica magnética das rochas analisadas foi determinada pela soma das contribuições dos minerais ferromagnéticos e paramagnéticos presentes. 


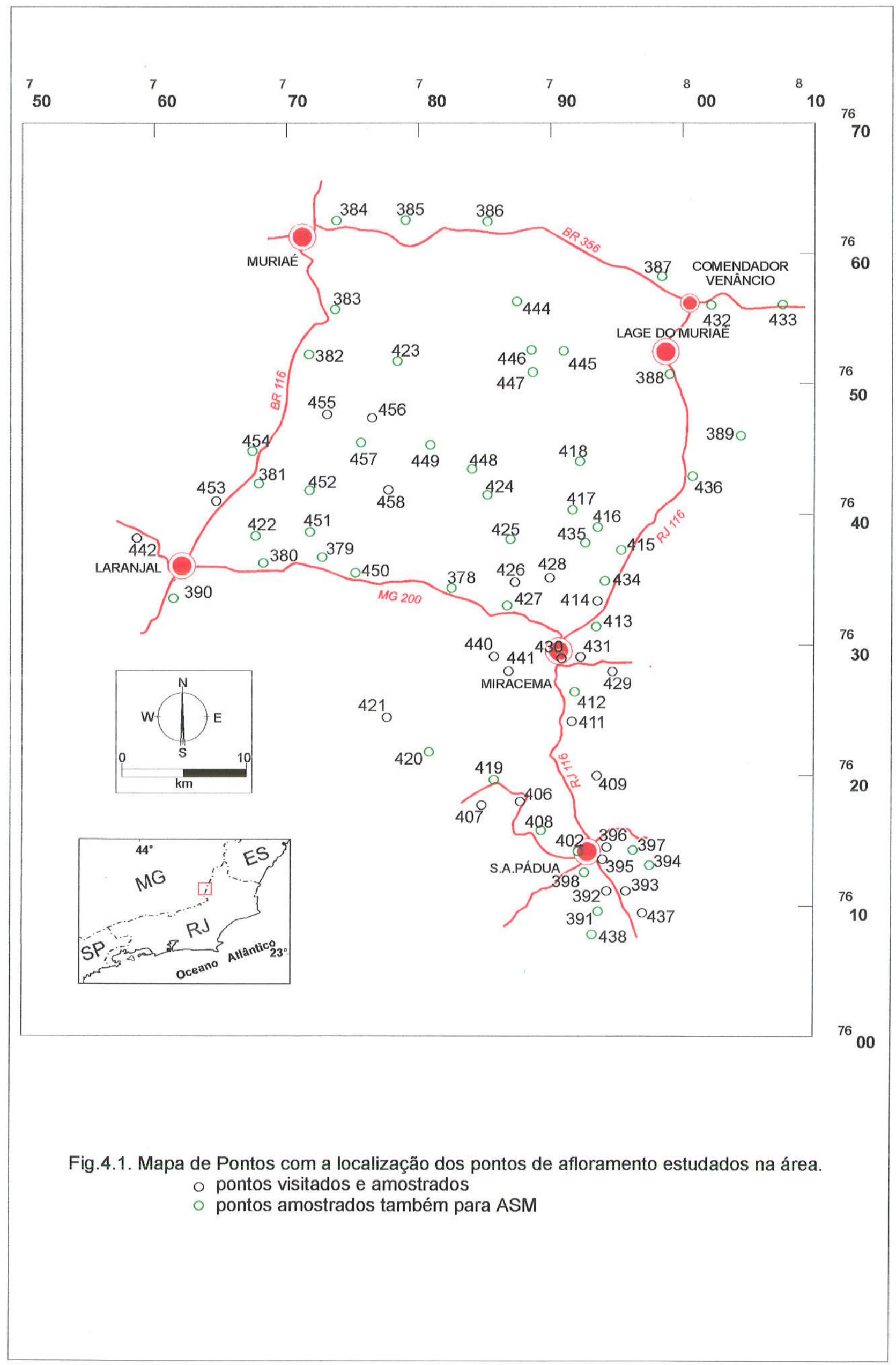




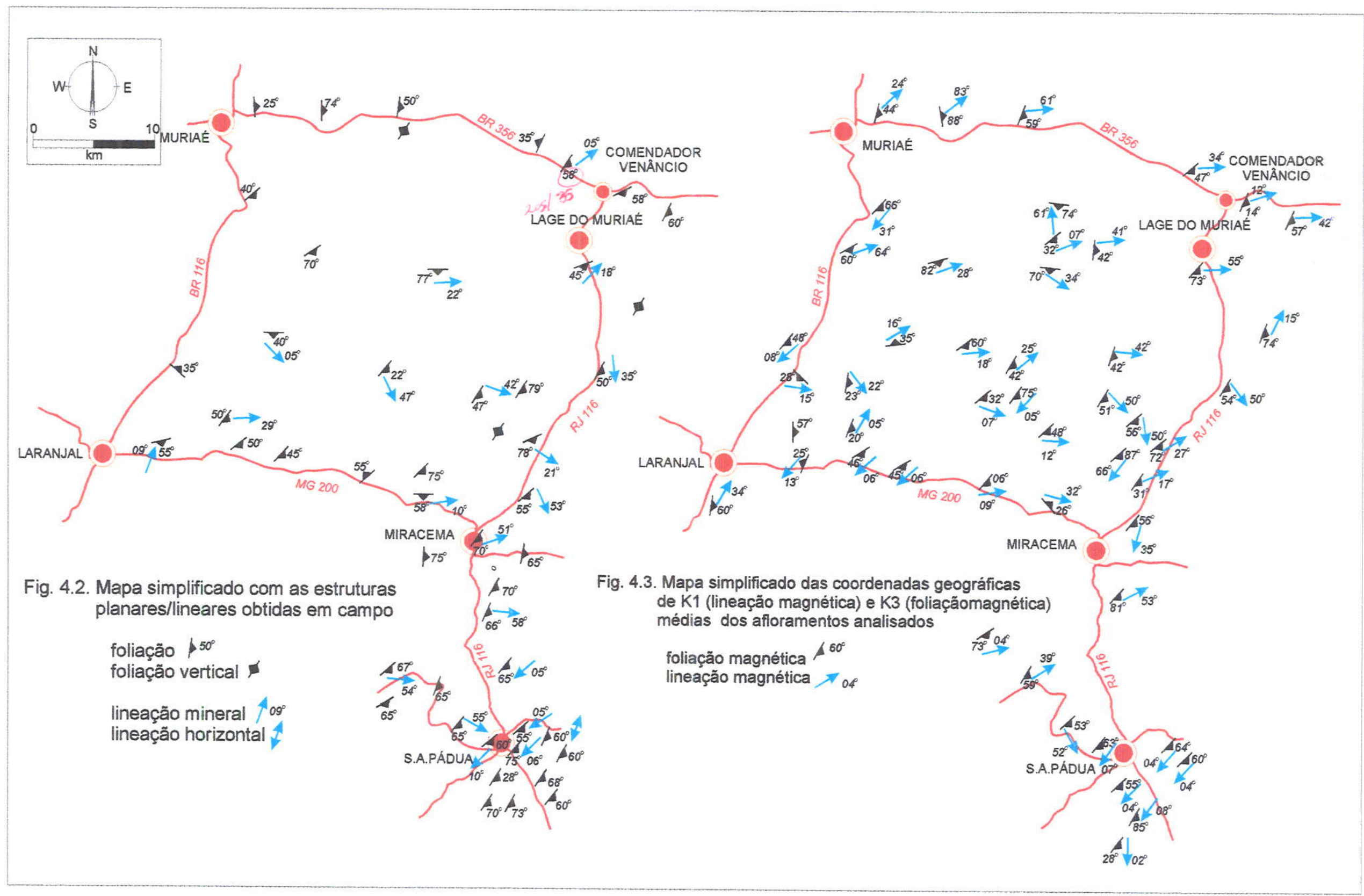




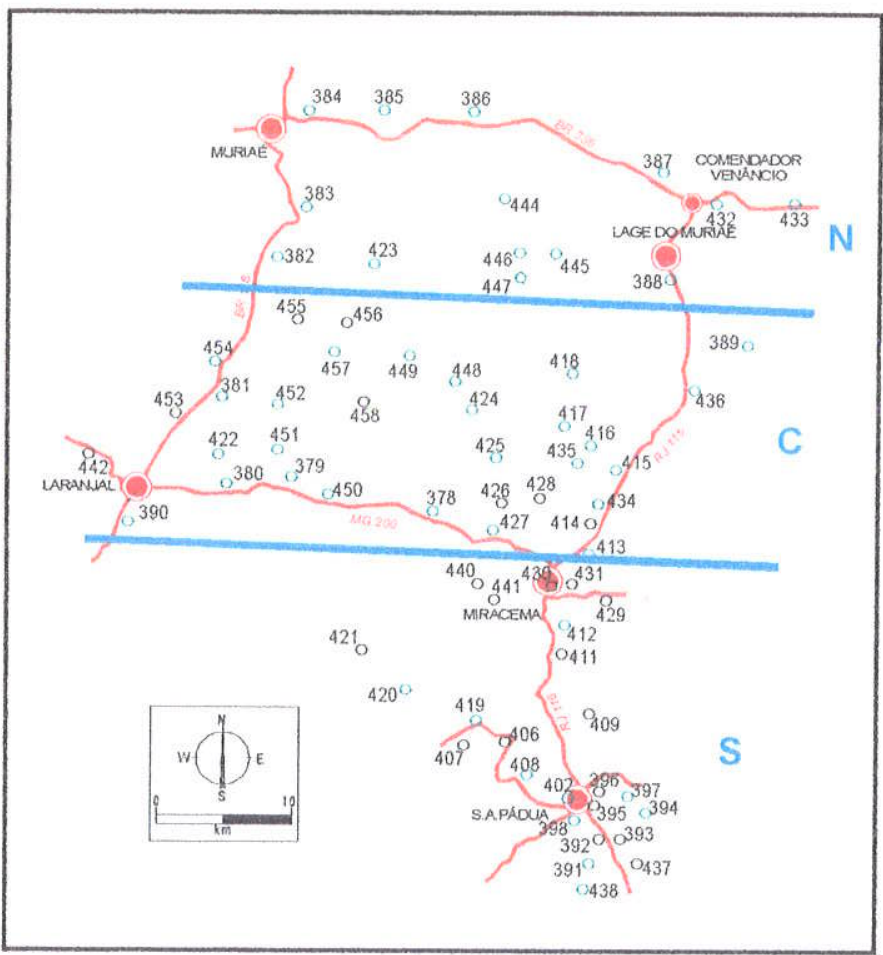

Fig. 4.4. Mapa esquemático com a divisão da área em setores.

De acordo com a orientação predominante da direção dos planos de foliação, a área foi dividida em setor norte (N), central (C) e sul (S), (traços em azul).

\subsection{Comparação da petrofábrica com a fábrica magnética}

No setor norte da área estudada, falhamentos de empurrão e direcionais se alternam e, foi verificada uma inflexão da direção do plano das foliações, de NE para NW. (fig.4.2., fig.4.3., fig.4.5.)

Ao longo da estrada entre Comendador Venâncio e Muriaé, a direção dos planos das foliações inflete, de direções NE - NNE com mergulhos subverticais e de alto ângulo para SE, próximo a Comendador Venâncio, para direções NS, com mergulhos de alto a médio ângulo para $E$, próximo a Muriaé. Direções próximas a EW, com mergulho de alto ângulo para sul, associadas à lineações paralelas de baixo ângulo, foram também verificadas.

As foliações magnéticas correspondentes apresentam direções NE, com mergulhos de médio ângulo, próximo à Comendador Venâncio, infletindo para direções NS - NW, com mergulhos de alto ângulo, próximo à Muriaé. Ocorrem também foliações EW, mergulhando para S. As lineações magnéticas ocorrem oblíquas, em alto ângulo com o plano de foliação e mergulho médio para $\mathrm{E}$.

Os estereogramas representando os afloramentos deste setor mostram K1, K2 e K3 fracamente concentrados na maioria dos afloramentos (e.g. fig.5.12., ests. 5, 33, 37, 38.). 


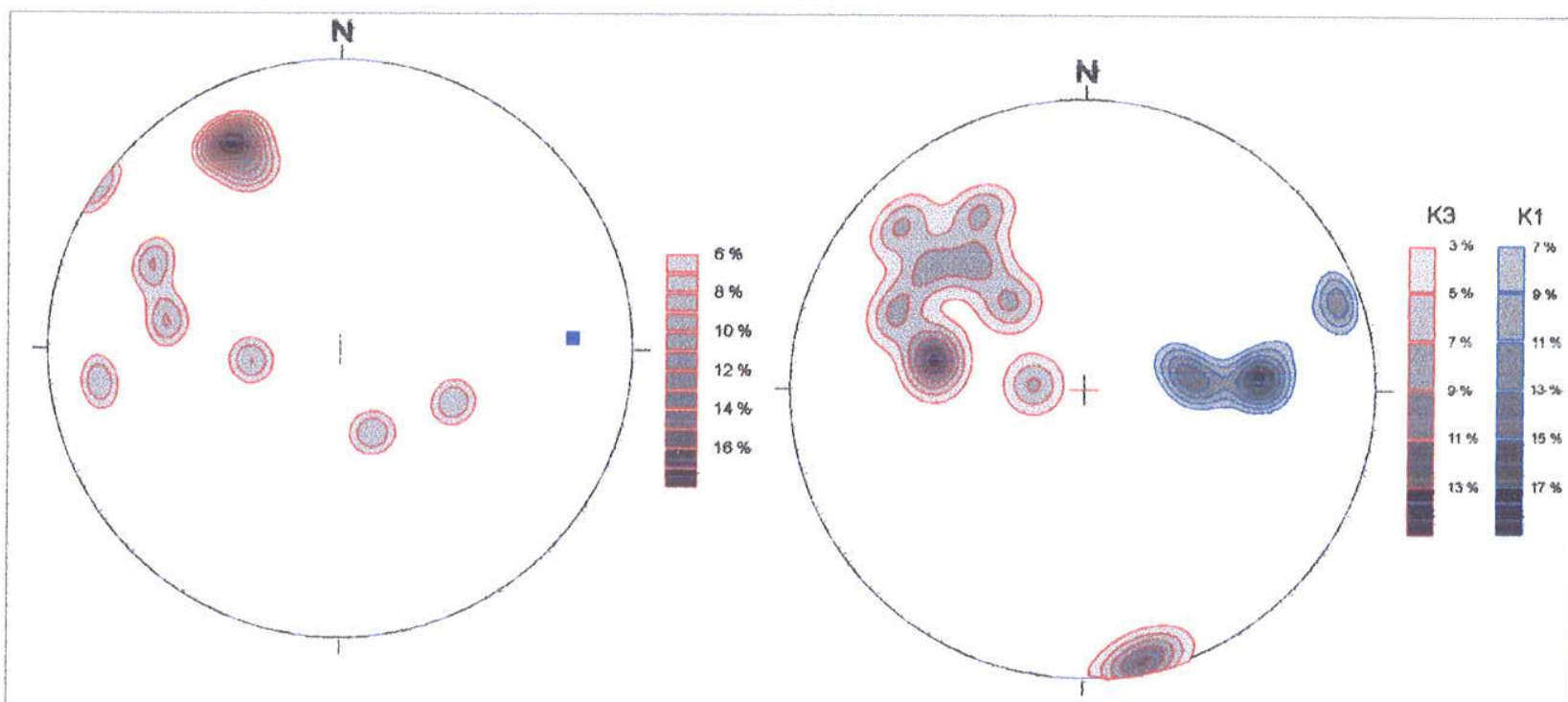

Fig.4.5. Diagramas de contorno com as atitutes de foliação e lineação no Setor Norte.

diagrama de contorno das foliaçäes de campo, (vermetho, $n=11$ ) e tineações (azul, $n=1$ ) diagrama de contorno das foliaçöes (vermetho, $n=14$ ) e lineaç̃es (azul, $n=14$ ) magnéticas

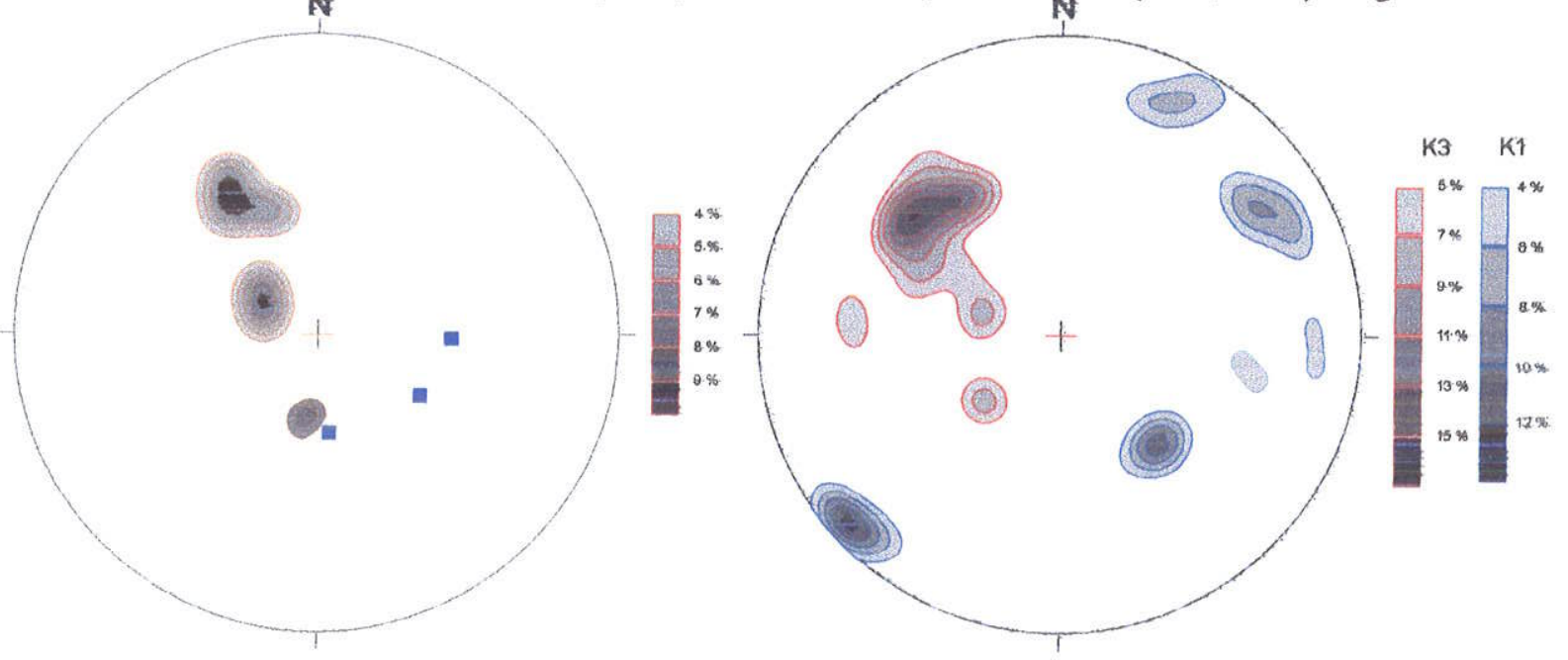

Fig.4.6. Diagramas de contorno com as atitutes de foliação e lineação no Setor Central. diagrama de contorno das foliações (vermelho; $n=22$ ) e tineações de campo (azul, $n=5$ )

diagrama de conforno das foliaçöes(vermelho, $n=25$ ) e lineações magnéticas (azul, $n=25$ )
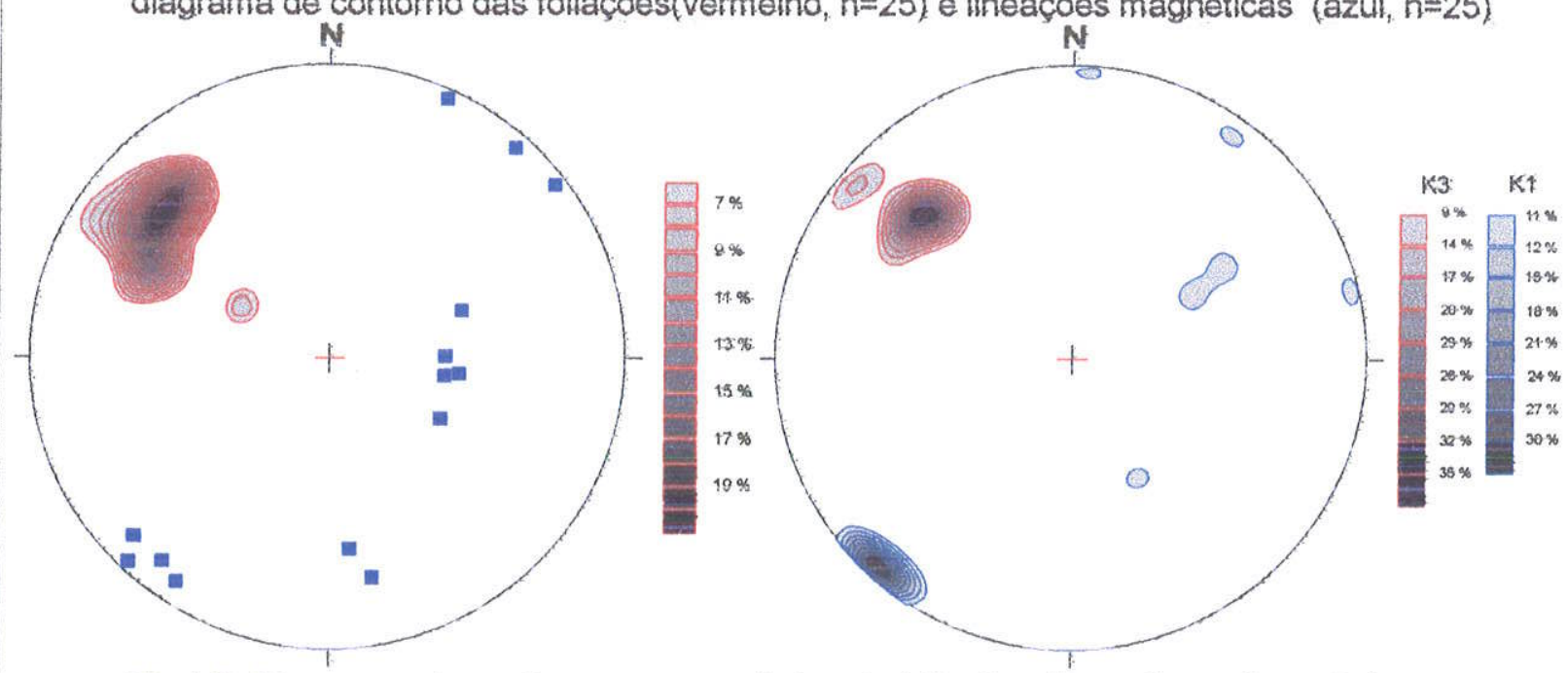

Fig 4.7. Diagramas de contorno com as atitutes de foliação e lineação no Setor Sul. diagrama de contorno das foliaçöes fvermelho, $n=37$ ) e lineaçôes (azul, $n=14$ ) de campo diagrama de contorno das foliações (vermelho, $n=10$ ) e lineações (azul, $n=10$ ) magnéticas 
A plotagem ' $\mathrm{T} \times \mathrm{P}$ ' para os afloramentos analisados no setor norte mostrou elipsóides de ASM levemente oblatos, com amostras plotando tanto no campo dos oblatos, quanto dos prolatos ou neutros (fig. 5.12., grafs. 9, 11, 32, 37, 38.).

O setor central da área estudada apresenta rochas com fábrica mesoscópica pouco visivel. Algumas foliações gnáissicas de direção e mergulho variados $e$, lineações escassas, foram encontradas em gnaisses granuliticos com granada e biokita do Complexo Juiz de Fora. (fig.4.2., fig.4.3., fig.4.6.)

As foliações mostraram planos com direção variando de NE a E-W, mergulthando em baixo a médio ângulo para SE. A direção preferencial EW acompanha falhamentos de mesma direção presentes, de mergulho alto.

Ao longo da estrada entre Laranjal e Muriaé, foram encontradas poucas foliações, de direções variadas, NE e EW, mergulho baixo para SE.

As lineações minerais mesoscópicas são escassas, em granada gnaisses e biotita - granada gnaisses, com direções oblíquas às direções dos planos de foliação e merguthos sub-horizontais.

Nas proximidades e ao longo da estrada Miracema - Laranjal, ocorrem planos de foliação gnáissica com direções NE a quase EW e, localmente NS. As atitudes variam entre N2OE - N8OE, concentradas em N40E, com mergulhos de médio a alto ângulo para SE.

Dobras com eixos paralelos à foliação regional ocorrem em gnaisse com muscovita pertencente ao Gnaisse Eugenópolis.

As lineações são raras, apenas em hornblenda-biotita-granada gnaisse do Complexo Juiz de Fora. Próximo à Miracema, a lineação de baixo ângulo mostrou direção EW, normal à direção do plano de foliação gnáissica, evidenciando a fábrica tangencial.

Próximo a Laranjal, a foliação gnáissica EW mergulha em médio ângulo para SE e, a lineação ocorre quase perpendicular à direção do plano de foliação, com baixo ângulo de mergutho.

As foliações magnéticas apresentam direção aproximada E-W e mergulho de médio a alto ângulo para $S$ e direções NE com mergulho de alto ângulo para SE.

As lineações magnéticas apresentam direções sub-paralelas à oblíquas, em baixo ângulo, às direções dos planos de foliação magnética, com mergulhos de médio a baixo ângulo, para SE.

Os estereogramas, representando os afloramentos desta porção do setor central, mostram $\mathrm{K} 1, \mathrm{~K} 2$ e $\mathrm{K} 3$ fracamente agrupados, com a dispersão aumentando de leste para oeste (e.g. fig.5.12., ests. $4,5,6,23,35,39,40,44$.). 
A plotagem T $\times P^{\prime}$, destes afloramentos, mostrou elipsóides de ASM variando entre francamente oblatos (e.g. fig.5.7., grafs. $23,45,24,29,35,44)$ a prolatos e/ou neutros (fig.5.7., grafs. $4,5,6,11,28,30,47,39,48,40$.).

Ao longo da estrada entre Miracema e Lage do Muriaé, as foliações mostram planos concentrados na direção N3OE, mergulhando para sudeste em ángulo médio. Uma segunda direção de foliação, provavelmente mais antiga, mostra direção NW e mergulho de alto ângulo para SW.

A transposição da foliação gnáissica por foliação milonítica evidenciou a presença de estruturas anteriores, sugerida pela presença de planos de foliação com direção NW e por lineação de intersecção NS de médio ângulo.

As lineações minerais, de biotita em biotita gnaisse granulítico, com direção NW e baixo ângulo de mergulho e de estiramento de feldspato em granada gnaisse milonítico, com direção NE e baixo ângulo de mergulho.

As foliações magnéticas correspondentes apresentaram direção preferencial NE, variando de NS, N2OE a N4OW, e com mergulhos de baixo ângulo a médio ângulo para SE, NW e NE.

As lineações magnéticas mostraram direção NE com mergulho baixo para SE e, localmente, direção SW e mergulho para SE, paralelas aos planos de foliação, exceto próximo a Laranjal, onde a foliação magnética, próxima da direção NS, mergulha em alto ânguio para $E$ e, a lineação ocorre obliqua ao plano de foliação, com merguiho médio.

Os estereogramas correspondentes mostraram dispersão de $\mathrm{K} 1, \mathrm{~K} 2$ e $\mathrm{K} 3$ (fig. 5.12 ., ests. $1,2,3,26,30,31,41$ ), exceto num afloramento de granada gnaisse granulítico do Complexo Juiz de Fora (fig.5.7., graf.42.), que mostrou alta concentração estatística das atitudes magnéticas.

A plotagem de $T \times P^{\prime}$, para os mesmos afloramentos, mostrou elipsóides de ASM variando entre oblatos, prolatos e/ou neutros, sem predominância num mesmo afloramento (fig.5.7., grafs.1, 2, 3, 26, 30, 31, 41.). Apenas um afloramento, de granada gnaisse granulitico pertencente ao Complexo Juiz de Fora (fig.5.7., graf.42.) que mostrou medidas magnéticas fortemente agrupadas, apresentou elipsóides prolatos.

No setor sul da área, próximo às cidades de Santo Antônio de Pádua e Miracema, a concentração dos planos de foliação milonítica apresenta direção preferencial nordeste, entre N4OE-N50E, com mergulho de alto ângulo para SE, em torno de 6OSE. (fig.4.2., fig.4.3., fig. 4.7.) 
As lineações de estiramento apresentam direção preferencial NE, N40E-N50E, concordante com a direção dos planos das foliações, com merguhos sub-horizontais para SE.

Dobras com plano axial paralelo à direção preferencial dos planos de foliação, N4OE com mergulho de alto ângulo para SE, foram observadas em gnaises granulíticos, finamente bandados, com biotita.

Os indicadores cinemáticos, marcados por porfiroblastos rotacionados de feldspato e granada, encontrados preferencialmente em paragnaisses miloníticos pertencentes ao Complexo Paraíba do Sul, indicam sentido de movimento dextrogiro, localmente ocorrendo simétricos.

A foliação magnética apresenta direção preferencial nordeste, N4OE-N50E, com mergulho de alto ângulo, $55^{\circ}$ a $81^{\circ} \mathrm{SE}$. As lineações magnéticas apresentam direção NE, paralela à das foliações, com caimentos sub-horizontais. As lineações magnéticas plotaram em guirlanda de atitude aproximada N4OE/60SE, sugerindo sua rotação ao longo deste plano, sob cisalhamento simples.

Os estereogramas referentes aos aftoramentos deste setor mostram coordenadas geográficas de $\mathrm{K} 1, \mathrm{~K} 2$ e $\mathrm{K} 3 \mathrm{com}$ forte agrupamento estatístico, tanto nas litologias granuliticas do Complexo Juiz de Fora (fig.5.12, est. 16, 17 e 18) como nos gnaisses do Complexo Paraíba do Sul (fig.5.12., est. 14 e 19).

A plotagem de $T \times P^{\prime}$, para os afloramentos analisados, mostrou elipsóides de ASM oblatos (fig. 5.7., grafs.14, 15, 16, 17, 18.) e apenas um afloramento com distribuição equivalente entre amostras entre elipsóides oblatos e prolatos (fig.5.7. graf.46.).

Próximo à cidade de Miracema, a foliação milonítica apresenta direção preferencial NE, variando entre N30 E - N50 Ecom mergulhos para SE de alto ângulo.

As lineaçőes estiramento de feldspatos ou lineaçăo mineral dada por biotita elou anfibólio são concordantes entre si, paralelas ou oblíquas à direção dos planos de foliação milonítica, com mergulhos de médio a alto ângulo.

Os indicadores cinemáticos, marcados por porfiroblastos rotacionados de feldspato e boudins, indicam sentido de movimento dextrogiro.

A foliação magnética apresenta direção preferencial NE, com mergulhos para SE de alto e médio ângulo. As lineações magnéticas são paralelas à direção do plano de foliação magnética.

Os estereogramas, referentes aos afloramentos desta porção do setor sul, mostram forte concentração estatística em granulito s.s. (fig.5.12., est. 34.) e leve dispersão em gnaisse granulítico (fig.5.12., est. 20.) do Complexo Juiz de Fora e em gnaisse milonítico 
do Complexo Paraíba do Sul (fig.5.12., est.21.).A plotagem de $T \times P^{\prime}$ para os afloramentos correspondentes mostrou elipsóides de ASM predominantemente oblatos (fig.5.7., grafs. 20, 21 e 34.).

A plotagem, em diagramas de contorno, das atitudes de foliação e lineação verificadas em campo (fig.4.8.) e, a plotagem das atitudes de foliação e lineação magnéticas (fig. 4.9.), foi feita em rede de Schmidt, hemisfério inferior, para visualização e comparação dos dados representativos das fábricas mesoscópica e magnética.

O estereograma representativo das atitudes obtidas em campo evidenciou a concentração da direção dos planos de foliação ao longo da direção nordeste, com plano médio de atitude N42E / 55SE, concordante com a atitude média da estrutura regional que controla o padrão estrutural da área, a Zona de Cisalhamento Além Paraíba.

As lineações são de difícial identificação na maior parte das litologias da área, exceto no setor sul e limite leste, que mostraram interferência direta da zona de cisalhamento.

As lineações plotam ao longo de uma guirlanda de atitude N34E / 43SE. A plotagem conjunta das lineações da área causa esta diferença entre a atitude do plano médio da foliação e o plano definido pelas foliações, pois as foliações representadas refletem, predominantemente, o comportamento do setor sul.

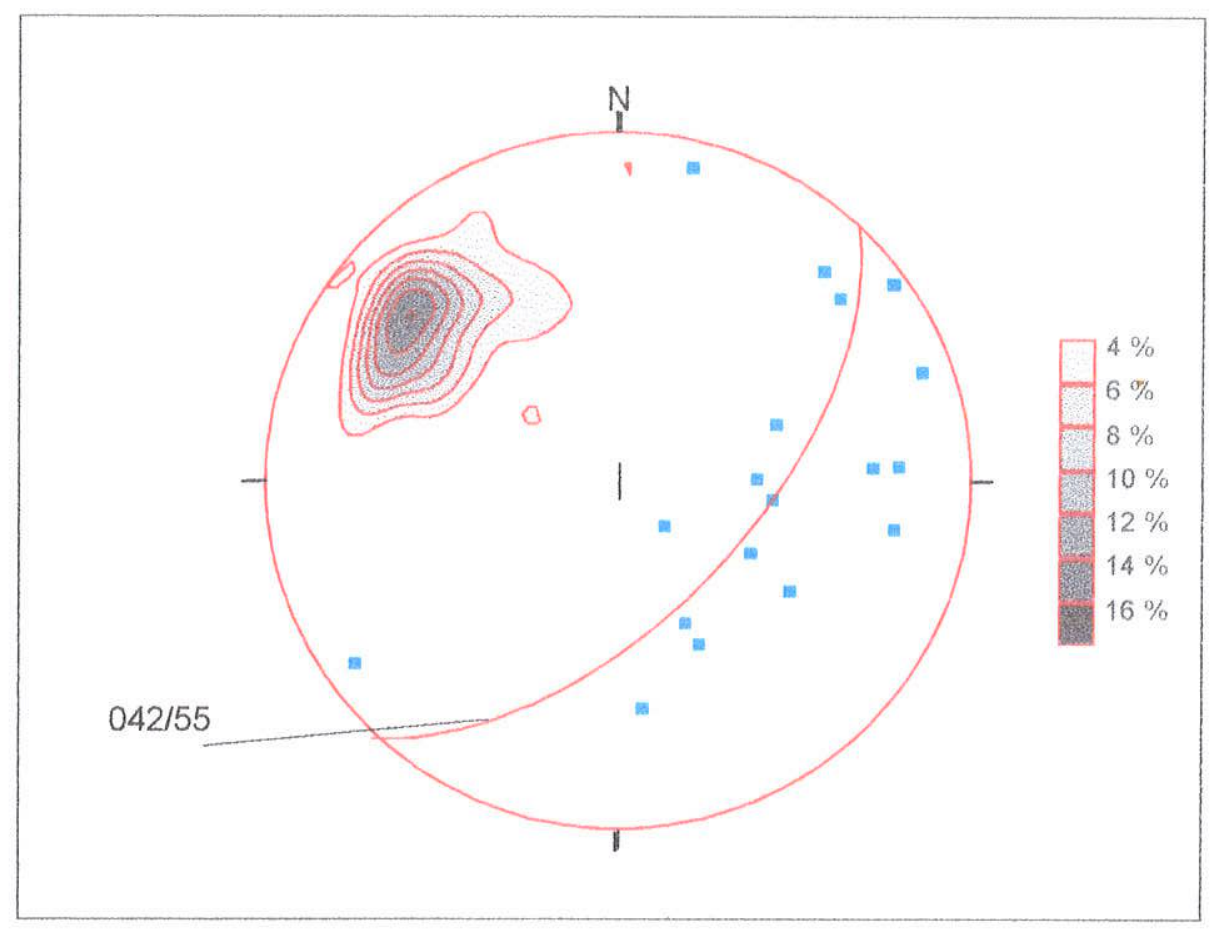

Fig. 4.8. Estereograma com as atitudes das foliações e lineações obtidas em campo Diagrama de contorno: foliações, $n=45$, pico $=18 \%$, plano médio (Fischer): 042/55 Em azul: lineações, $n=21$ 
O estereograma representativo das atitudes obtidas pela aplicação da ASM evidenciou a concentração da direção dos planos de foliação ao longo da direção nordeste, com plano médio de atitude N43E / 59SE, de mesma atitude que o plano médio de foliação dado pelas atitudes de campo.

As lineações plotam ao longo de uma guirlanda de atitude N45E/60SE concentradas em 223;06 e 052;14, evidenciando deslizamento sub-horizontal ao longo de um plano de direção nordeste. A concentração de lineações de médio ângulo na direção EW sugere movimento para oeste, ao longo da direção E-W, principalmente no setor norte da área.

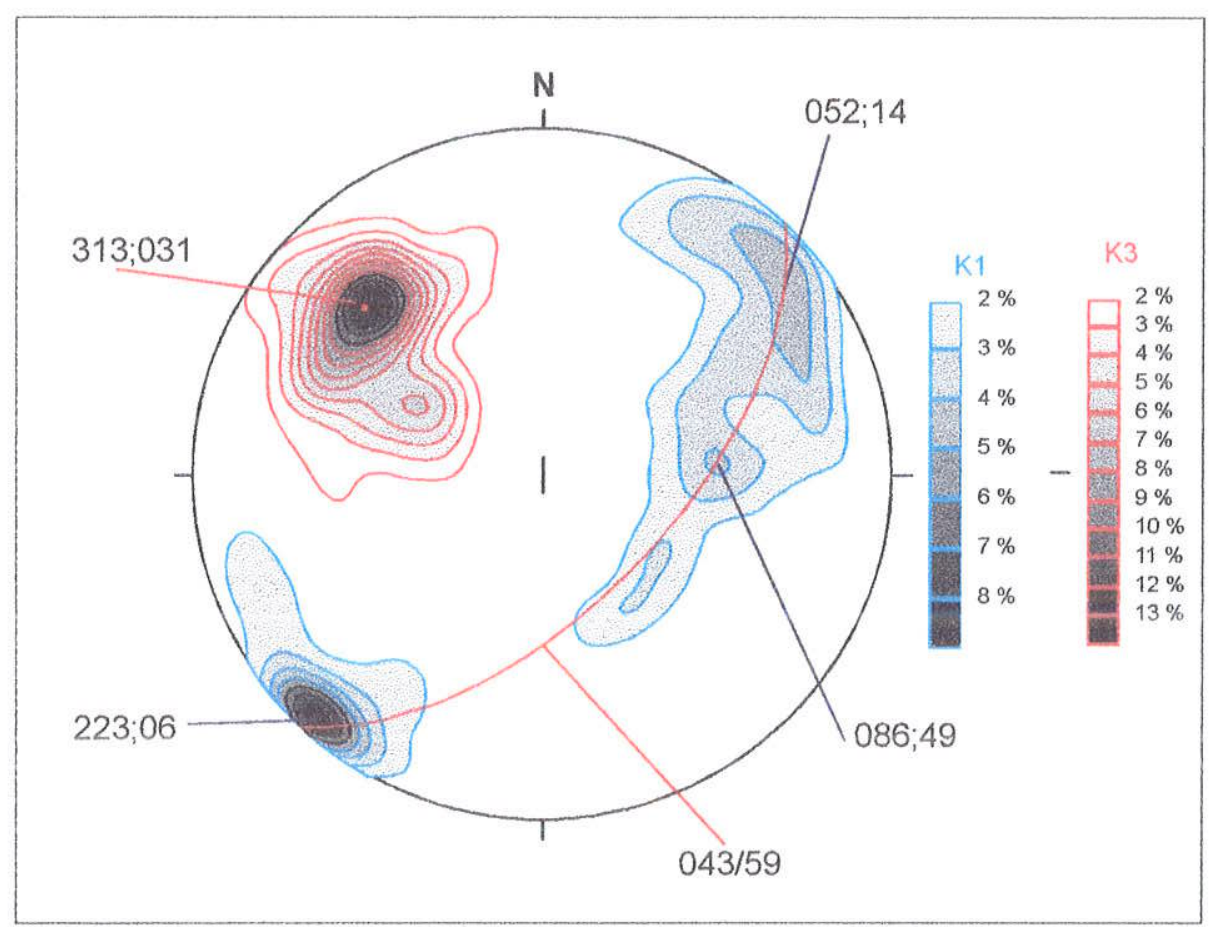

Fig. 4.9. Diagramas de contorno com as atitudes das coordenadas geográficas dos autovetores de ASM, K1 e K3. As atitudes plotadas são representativas da média de cada afloramento.

Contorno vermelho: atitudes de K3, correspondentes aos pólos das foliaçöes magnéticas, $n=49$

Contorno azul: atitudes de K1, correspondentes às lineações magnéticas, $n=49$

O plano em vermelho mostra a guirlanda ao longo da qual as lineações plotaram, de mesma atitude do plano médio que representa as foliações magnéticas. 043/59

A análise dos dados estruturais apresentados evidenciou a presença de comportamentos tectônicos distintos na área, caracterizando um domínio com tectônica direcional predominante, no setor sul e, um domínio de transição, onde ocorre tectônica tangencial associada a falhamentos direcionais, nos setores central e norte.

O domínio tangencial apresenta planos de foliação de baixo ângulo $\left(<30^{\circ}\right)$, com deslocamentos perpendiculares ou oblíquos em alto ângulo às direções dos planos de 
foliaço. O domínio direcional apresenta planos de foliaça de mergulho alto, com deslocamentos horizontais ou sub - horizontais, paralelos aos planos da foliação milonítica.

As atitudes de foliação e lineação magnética permitiram a elaboração de diagramas de contorno representativos do comportamento do dominio tangencial (ig.4.10.) e direcional (ñg.4.11.), pois as estruturas de campo nảo foram verificadas em quantidade estatística suficiente para esta análise, tendo sido usadas apenas para contirmaçäo.

A análise do estereograma que representa a fábrica tangencial verificada na área indicou três direções preferenciais dos planos de foliação: uma primeira direção, NW, subhorizontal (236/03), uma segunda direção, NE, de baixo ângulo (320/27) e uma terceira direçâo, aproximadamente NS (014/20).

O plano médio, definido por estas concentraçóes (124/83), reflere o lineamento que controla o setor norte, de traç aproximado NW e, se repete, infletindo para EW, no setor central da área, de direção normal à direção da zona de cisahamento que controla os setores sul e limite oriental da área. (veja fig. 4.12. e Mapa Geológico, Anexo 3).

As lineaçóes, reterentes à estas foliaçôes, embora fortemente concentradas $(070 ; 10)$ plotaram em guirlanda, de atiude N40E/19SE, com direção similar à encontrada no plano médio das foliaçōes de campo e magnéticas, direção esta levemente obliqua à guirlanda ao longo da qual plotam as lineaçôes de campo (10 dextrogira). A autude média das lineaçóes (070;10), indica movimento para oeste, ao longo de uma direção próxima à EW, com merguho suave.

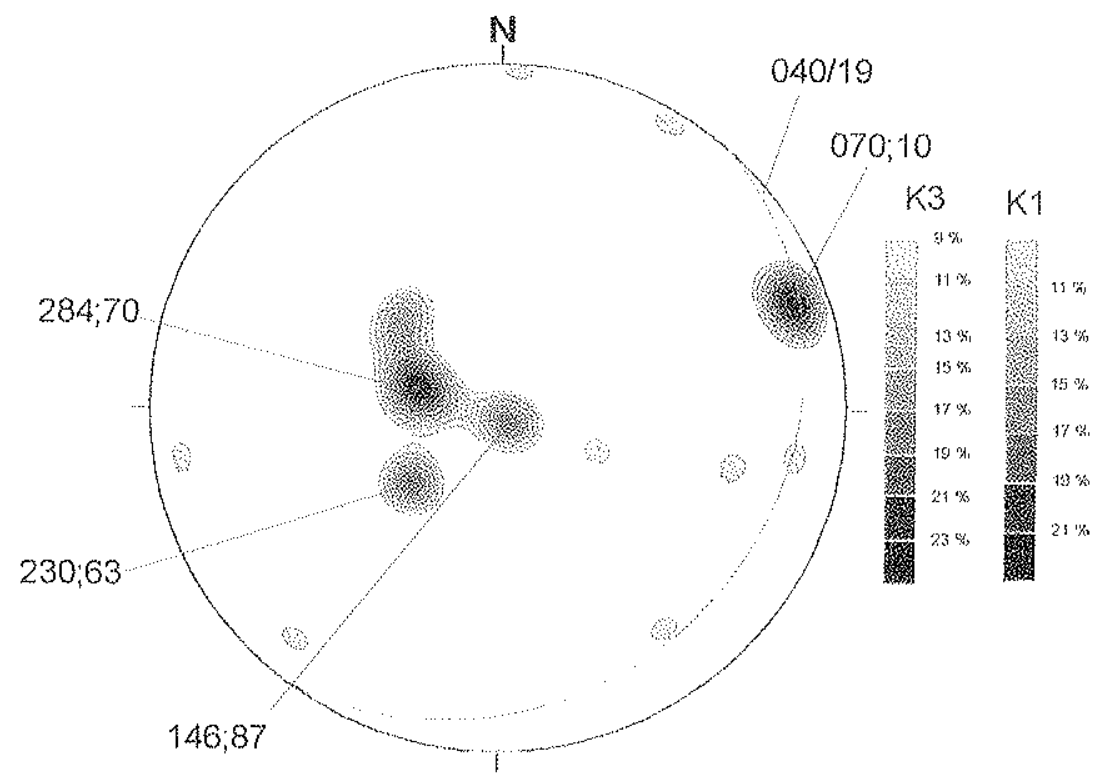

Fig.4.10. Diagrama de contomo das atitudes magnéticas (médias) no domínio tangencial Contorno vermelho: atitudes de $K 3$, correspondentes aos pólos das foliaçöes magnéticas, $n=10$, Contomo azul: atitudes de $K 1$, correspondentes às lineaçôes magnéticas, $n=10$. 
A análise do estereograma que representa a fábrica direcional, verificada na área, indicou planos de foliação com direção média N43E/56SE, concordante com a direção da zona de cisalhamento que ocorre no setor sul, onde o domínio direcional é proeminente.

As lineações, referentes à estas foliações, plotaram em guirlanda de atitude N40E/59SE, com direção similar à encontrada no plano médio das foliações de campo e magnéticas e, igual à direção da guirlanda ao longo da qual plotaram as lineações no domínio tangencial, do qual difere em $40^{\circ}$, quanto ao ângulo de mergulho.

As lineações plotam ao longo de uma guirlanda de atitude N40E/59SE, concentradas em 225;06, 140;51, 088;40 e 053;25.

O deslizamento ao longo de um plano (043/56), com mergulho pronunciado para sudeste e direção nordeste, semelhante à orientação da zona de cisalhamento, confirma ser este o principal plano de cisalhamento na área.

A concentração de lineações de médio ângulo na direção EW, também presente no domínio tangencial, sugere movimento para oeste, ao longo da direção E-W.

A concentração das lineações em 225;06 sugere deslizamento sub-horizontal ao longo de um plano nordeste, de NE para SW. Este deslizamento rotaciona lineações NE progressivamente para EW e SW, ao longo do plano de cisalhamento nordeste.

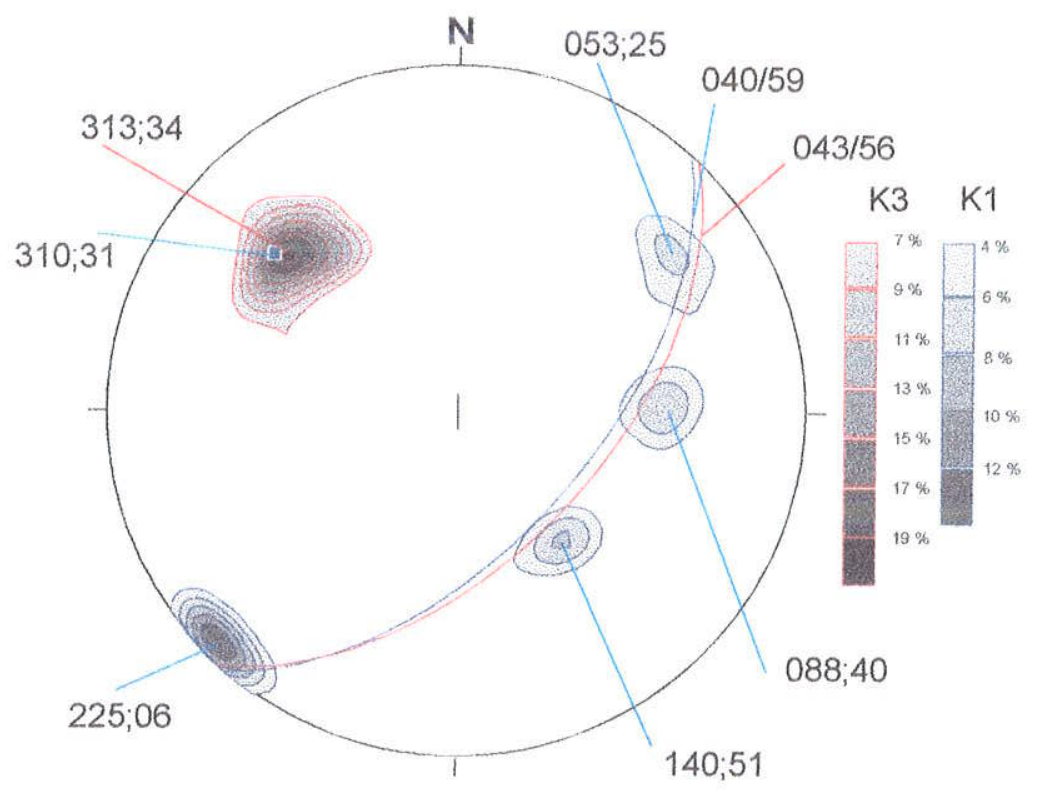

Fig.4.11. Diagrama de contorno das atitudes magnéticas (médias) no domínio direcional Contorno vermelho: atitudes de K3, correspondentes aos pólos das foliaçöes magnéticas, $n=39$, Contorno azul: atitudes de K1, correspondentes às lineações magnéticas, $n=39$, 


\subsection{Interpretação e discussão dos dados}

O setor sul da área deste trabalho apresentou as direções dos planos de foliação com direções preferenciais NE, com mergulhos de alto e médio ângulo para SE. As lineações destes setores ocorrem paralelas às direções dos planos de foliação, de direções NE com mergulhos suaves, médios ou altos para SE. A fábrica predominante é direcional.

Os setores central e norte mostraram planos de foliação de direção NE, de médio a alto ângulo e, planos de foliação NW, com mergulhos médios a baixos para SW, transpostos pela foliação NE, evidenciando a presença de estruturas anteriores.

As lineações nestes setores ocorrem oblíquas, em médio ou alto ângulo com as direções dos planos de foliação, e mergulhos suaves a médios para SE e S.

O controle estrutural é dado por lineamentos NE, predominantes no setor sul e limite oriental, associados à Zona de Cisalhamento Além Paraíba e, por lineamentos NW, predominantes no setor central e sul da área. (fig.4.12.)

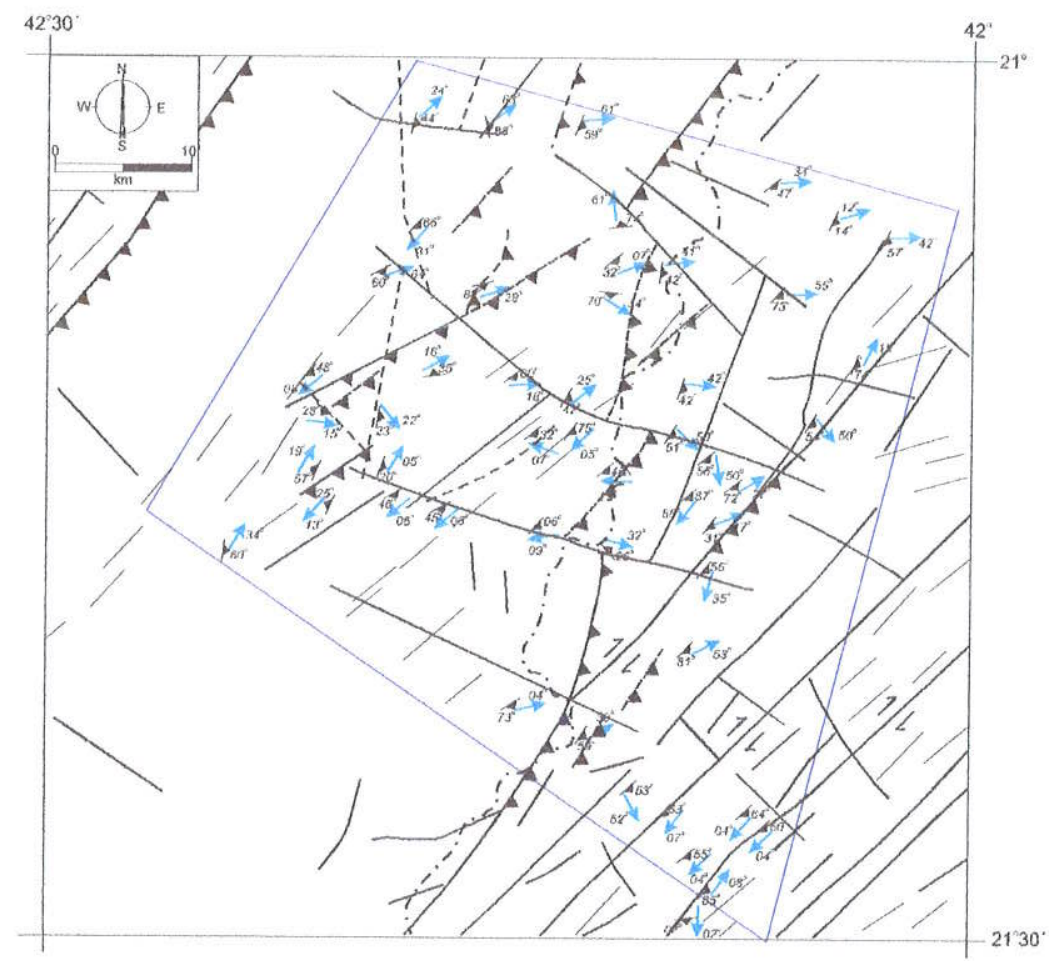

Fig.4.12. Mapa esquemático das estruturas presentes na área estudada. (para maiores detalhes, veja Mapa Geológico, Anexo 3)

A área apresenta comportamento cinemático coerente com movimento de NE para SW, ao longo de um plano de alto ângulo, com atitude aproximada N40E/60SE. 
Os indicadores cinemáticos, identificados principalmente no setor sul, sugerem sentido de movimento dextrogiro ou, localmente ocorrem simétricos, sugerindo a presença de uma componente de cisalhamento puro.

Os falhamentos de empurrão e os falhamentos transcorrentes estão associados às inversões estratigráficas de grau metamórfico nas litologias presentes, que mostram blocos de rochas granuliticas e gnáissicas orto- e paraderivadas, na fácies granulito, rotacionados e estratigraficamente invertidos, anastomosados com blocos de gnaisses na fácies anfibolito, granitóides e charnockitos.

As rochas de embasamento e supracrustais, que constituem estes blocos, apresentam foliações com mergulhos variáveis $e$, blocos litológicos correlacionáveis apresentam freqüente inconsistência na direção e mergulho de suas foliações e lineações.

No setor sul da área, próximo da zona de deslocamento principal da Zona de Cisalhamento Além Paraíba, os dados indicam predominância de tectônica direcional, ao longo de falhamentos transcorrentes de alto ângulo, de direção preferencial NE, que expuseram rochas granulíticas e gnáissicas da base da crosta, deformadas sob regime dúctil. Estes setores apresentam foliações NE, com mergulho alto e lineações subhorizontais indicando deslocamento para SE.

Nas bordas dos blocos limitados pelas zonas de cisalhamento as lineações são paralelas à direção do plano de follação, com mergulhos de ângulo alto a médio, com atitudes de foliação em torno de N30 - 50E/25 - 70SE.

No centro destes blocos, onde a deformação mostrou menor intensidade, a foliação, de baixo mergulho, mostra lineações oblíquas ou normais à direção do plano de foliação, sugerindo que o núcleo dos blocos preservou uma foliação tangencial, pré-existente à foliação de alto ângulo, sugerindo que os empurrões precedem a transcorrência.

As atitudes da foliação mostraram direção predominante NE, de médio a alto ângulo. No domínio tangencial, setores central e norte, ocorre foliaçäo subordinada NW, de baixo ângulo, transversal ao trend estrutural NE, predominante no setor sul, com relação temporal dúbia, em relação à foliação NE, possivelmente significando uma foliação préexistente. A presença de dobras com planos axiais NNE e flancos merguihando para SE, confirma a vergência tectônica para Oeste.

A fábrica tangencial indicou compressão frontal, devida a esforços vindos de leste em direção à oeste $e$, a fábrica direcional evidenciou a transcorrência dextrogira de direção nordeste - sudoeste, evidenciando uma partição na direção dos movimentos, que provocou o destizamento de massa rochosa, de nordeste em direção a sudoeste. 
Os dados que possibilitaram a visualização das direções e sentidos de movimento, dos blocos aflorantes na área, foram obtidos, predominantemente, pela aplicação da ASM, na determinação da fábrica das rochas e dos movimentos ocorridos na área.

O comportamento cinemático, visualizado a partir do tratamento dos dados obtidos, sugere um modelo evolutivo para a área, onde as rochas (paleoproterozóicas) foram retrabalhadas num ambiente tectônico colisional (neoproterozóico), gerado por convergência $E-W$, sob regime transpressivo.

Esta convergência provocou cavalgamentos oblíquos, em direção à oeste, ao longo de planos de deslizamento de baixo mergulho (040/19), predominantes no norte e centro da área. Estes cavalgamentos oblíquos responderam pela presença de dobras, com eixos NE-SW e flancos EW, mergulhando suavemente para sul, numa evidência de vergência tectônica para oeste, em direção ao Cráton do São Francisco.

As falhas direcionais no limite leste da área, apresentaram direção NE-SW, sentido dextrogiro, causaram deslizamento direcional sub-horizontal de massa de NE para SW, ao longo de um plano de alto ângulo (043/59).

A fábrica apresentou elipsóides oblatos predominantes e também elipsóides prolatos, evidenciando a partição da deformação, entre coaxial e não coaxial.

A fase tangencial, de cavalgamentos oblíquos, precedeu a fase transcorrente, dentro do mesmo evento transpressivo.

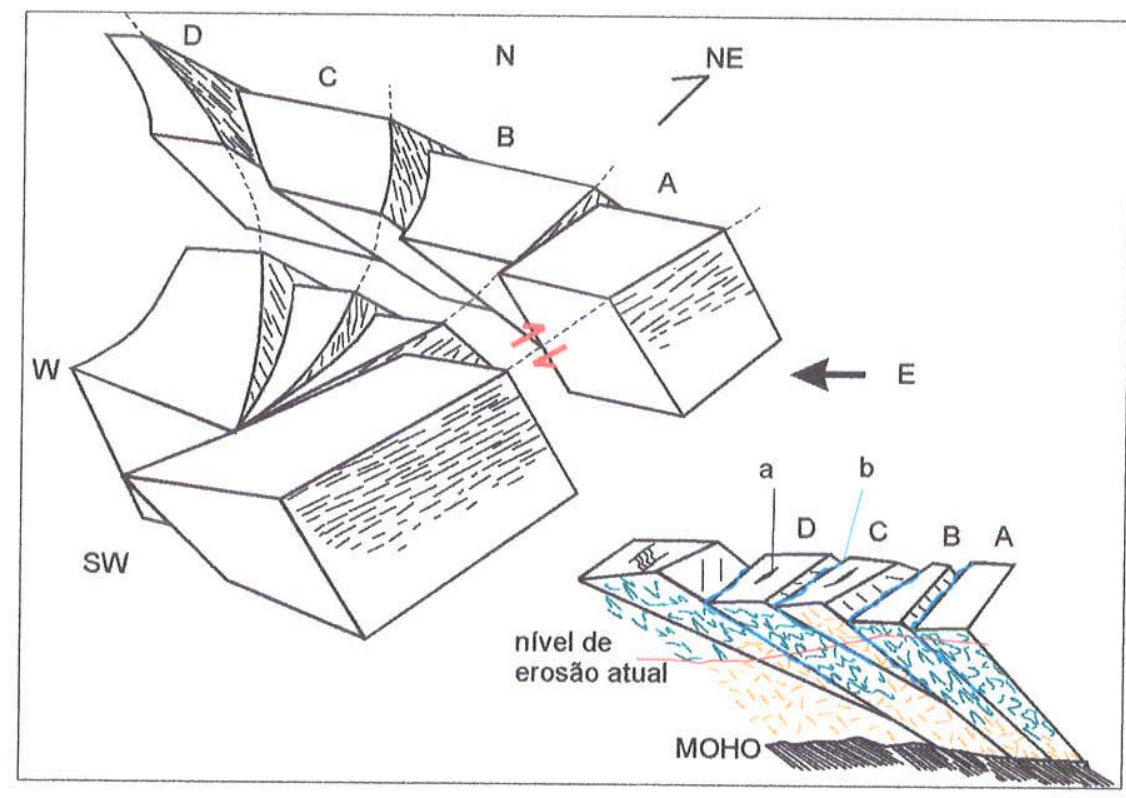

Fig. 4.13. Desenho esquemático representando a área estudada e suas estruturas principais.

A figura exemplifica os movimentos ocorridos nos blocos presentes na área e a posição das foliações encontradas. 
O nível de erosão atual expõe diferentes niveis crustais e diferentes atitudes das estruturas planares e lineares. a) No centro dos blocos ocorrem as rochas de alto grau metamórfico, soerguidas de ambientes anidros, com fábrica granoblástica, tectonitos S e SL, cisalhamento puro. b) Nos limites entre os biocos, em azul, observamos superificies de transporte, onde ocorrem rochas retrometamorfizadas, milonitos e tectonitos LS e SL, cisalhamento simples. (modificado de Brenner et al., 1980 e Ebert \& Hasui, 1998)

Os dados obtidos nesta dissertação são compativeis com os dados apresentados por Machado \& Endo (1993, 1993b) e Endo \& Machado (1993, 1993b), que adotam o modelo de regime transpressivo, com movimentação dextrogira, gerado por colisão frontal, para a parte central do Cinturão de Cisalhamento Atlântico, que abrange a área desta dissertação. Os autores relacionam os falhamentos de baixo e alto ângulo ocorrendo simultâneos, associados à presença de uma mega estrutura em flor positiva, desenvolvida sob regime transpressivo, cuja zona axial está ao longo da Zona de Cisalhamento Além Paraíba.

A verificação de estruturas com direções nordeste e mergulhos para sudeste, de baixo e/ou alto ângulo, principalmente no setor sul da área do presente trabalho, é compatível com a presença da estrutura em flor positiva, proposta em Machado (op.cit.),considerando que a zona axial desta estrutura fica abaixo e à direita da área.

Entretanto, os dados do presente trabalho apontam para cavalgamento oblíquo precedendo a transcorrência, durante um mesmo evento transpressivo, divergindo do modelo onde os empurrões e a transcorrência ocorrem simultâneos, devido à extrusão lateral e vertical de volume, ao longo da zona axial da estrutura em flor. É possível que este comportamento seja representativo do setor sul da área, onde predomina a fábrica direcional mas, nos setores central e norte, os empurrões precedem a transcorrência.

Vauchez et al. $(1992,1994)$ propôs colisão frontal da extremidade S-SW da placa Cráton do Congo-Cráton São Francisco com a mega-placa do Gondwana Ocidental, durante o Ciclo Brasiliano, que teria provocado os falhamentos de empurrão e, a instalação das zonas de cisalhamento dextrogiras, que acomodaram a deformação e promoveram escape lateral para S-SW, das massas rochosas envolvidas durante o processo de colisão. Esta proposta fol confirmada pelos dados obtidos no presente trabalho.

Ebert \& Hasui (1998) propuseram um modelo evolutivo que envolve colisão frontal, sob regime transpressivo, onde uma fase tangencial D1 precede uma fase direcional D2.

O deslizamento, ao longo de rampas laterais de baixo ângulo (domínios tangenciais), seria o responsável pela exumação de rochas de nível crustal mais profundo, onde o plano de deslizamento entre as rampas exibe feições caracteristicas de deformação não - 
coaxial e, no interior preservado dos blocos deslizados, ocorrem feições características de deformação coaxial.

Esta constatação, feita por Ebert, foi verificada em campo, durante os trabalhos desta dissertação e, evidenciada também pelas fábricas diferenciadas (elipsóides oblatos e prolatos) através dos dados de ASM.

O cenário cinemático, proposto em Ebert \& Hasui (1998), confirma o comportamento cinemático proposto e, a sugestão de evolução tectônica apresentada neste trabalho (veja fig.4.14.).

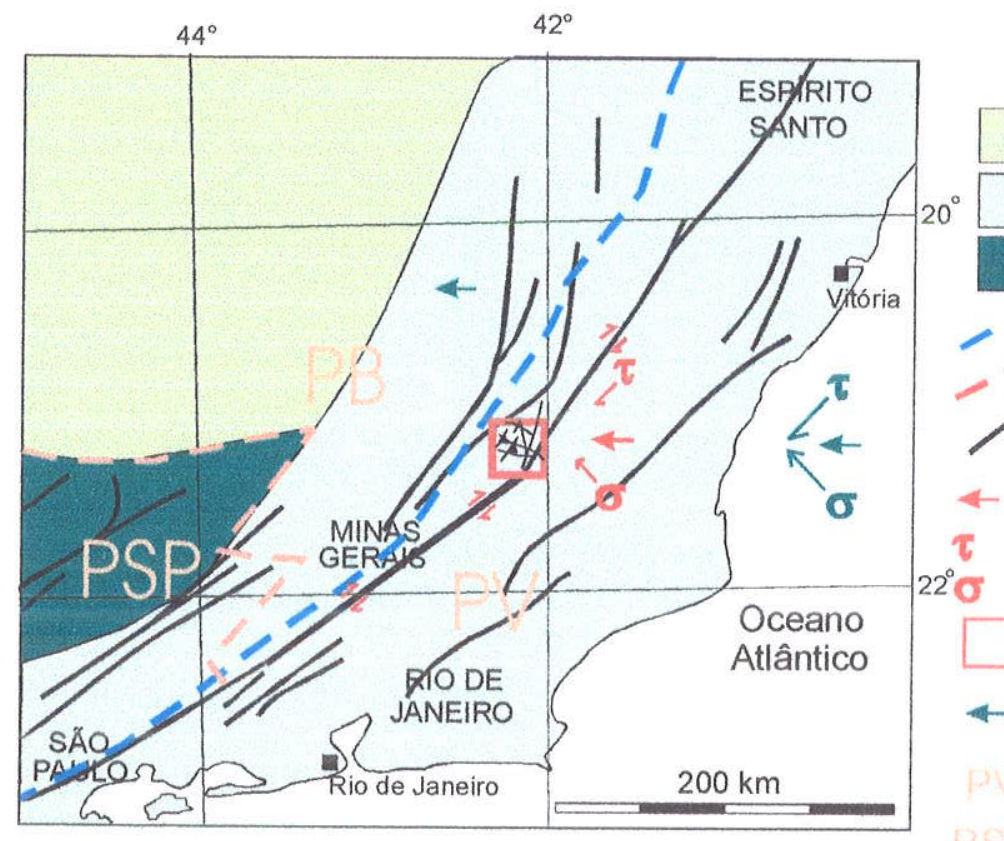

Cráton do São Francisco

Faixa Ribeira

Faixa Brasília

Zona de Sutura Abre Campo

Zona de Sutura Alteroza

Lineamentos principais

direção de convergência

shear stress

stress normal

área estudada nesta dissertação

direções de stress e convergência em Ebert \& Hasui, 1998

Placa Vitória

Placa São Paulo

Placa Brasília

Fig.4.14. Desenho esquemático do quadro tectônico que abrange a área desta dissertação, em mapa modificado de Ebert \& Hasui, 1998.

Para estudo comparativo, os vetores propostos em Ebert \& Hasui (1998) foram plotados (em verde) ao lado de uma sugestão da orientação dos esforços que atuaram sobre a área. 


\section{Medidas de anisotropia de susceptibilidade magnética}

A fábrica de uma rocha é homogênea quando a orientação das propriedades consideradas é a mesma em toda a amostra. Se a propriedade considerada foi orientada de maneira idêntica através de toda a amostra, então a fábrica apresenta um alinhamento de saturação e näo ocorre dispersão das direções, quando então, a direção média se define automáticamente.

Esta situação pode ser esperada quando a nucleação de minerais metamórficos produz um alinhamento muito forte, pela atuação do stress, como ocorre nas litologias metamórficas de alto grau presentes na área.

A fábrica magnética das rochas estudadas apresentou alinhamentos imperfeitos e nem sempre totalmente homogêneos, considerando um mesmo afloramento. O problema, quando existe muita dispersão nas amostras de um mesmo afloramento, consiste em como caracterizar a variação da fábrica, pois qualquer tratamento estatístico, como os necessários para o presente trabalho, requer um nível razoável de homogeneidade.

A dispersão das direções, ou a variação de uma propriedade, de uma amostra para outra, num mesmo afloramento e, também de um afloramento para o outro, precisa definir uma orientação de distribuição também homogênea.

As análises de ASM foram realizadas em aparetho Kappabridge, $\mathrm{KLY}$ - 3S, em 426 cilindros, de volume aproximado $10,8 \mathrm{~cm}^{3}$. Os dados obtidos, valores escalares e coordenadas geográficas dos autovetores $[K 1$ (máximo) $>K 2$ (intermediário) $>K 3$ (mínimo)], parâmetros de ASM $\left(P, H, T, P^{\prime}, L, F\right)$ e valores de susceptibilidade média $(\mathrm{Km})$, foram tabulados para tratamento analítico através de gráficos, mapas e estereogramas.

A tabulação dos dados vetoriais e escalares, referentes ao conjunto dos 426 cilindros analisados para ASM (tab.5.1.), evidenciou a homogeneidade relativa do alinhamento setorial dos dados vetoriais (coordenadas geográficas) e a complexidade da fábrica magnética. A baixa dispersão verificada possibilitou a plotagem dos valores médios dos dados, principalmente das coordenadas geográficas, que definiram o mapa onde as atitudes do par foliação/lineação magnética foram plotados.

Devido à complexidade da fábrica, os dados referentes a cada amostra, de um mesmo afloramento, foram plotados em gráficos (fig.5.7.) e estereogramas (fig.5.12.) individuais e, em gráficos de conjunto para parâmetros de anisotropia da fábrica, forma do elipsóide e grau de anisotropia das amostras.

O grau de anisotropia (P) (fig.5.2.) para o conjunto das amostras estudadas varia entre 1,0 e 1,52, com mais de $70 \%$ dos valores concentrados entre 1,0 e $2,5 \mathrm{SI}$. 
$P$ reflete o grau de deformação do elipsóide de ASM. Nas litologias do Complexo Juiz de Fora, P varia entre 1 e 3 (fig.5.4.) e, no Complexo Paraíba do Sul, varia entre 1 e 1,5 (fig.5.3.). Amostras com P muito elevados ocorrem no afloramento KJ417 (amostra KJ4173b, $P=4,416$ ), pertencente a um biotita-hornblenda gnaisse com muscovita, pertencente ao Gnaisse Eugenópolis e no afloramento KJ402 (amostra KJ4021a1, $\mathrm{P}=5,433$ ), (amostra $\mathrm{KJ} 4023 \mathrm{c} 1, \mathrm{P}=5,681$ ), ambas pertencentes a biotita-hornblendagranada gnaisse granulítico fortemente milonitizado pertencente ao Complexo Juiz de Fora, que apresentou magnetita primária e nas fraturas do piroxênio.

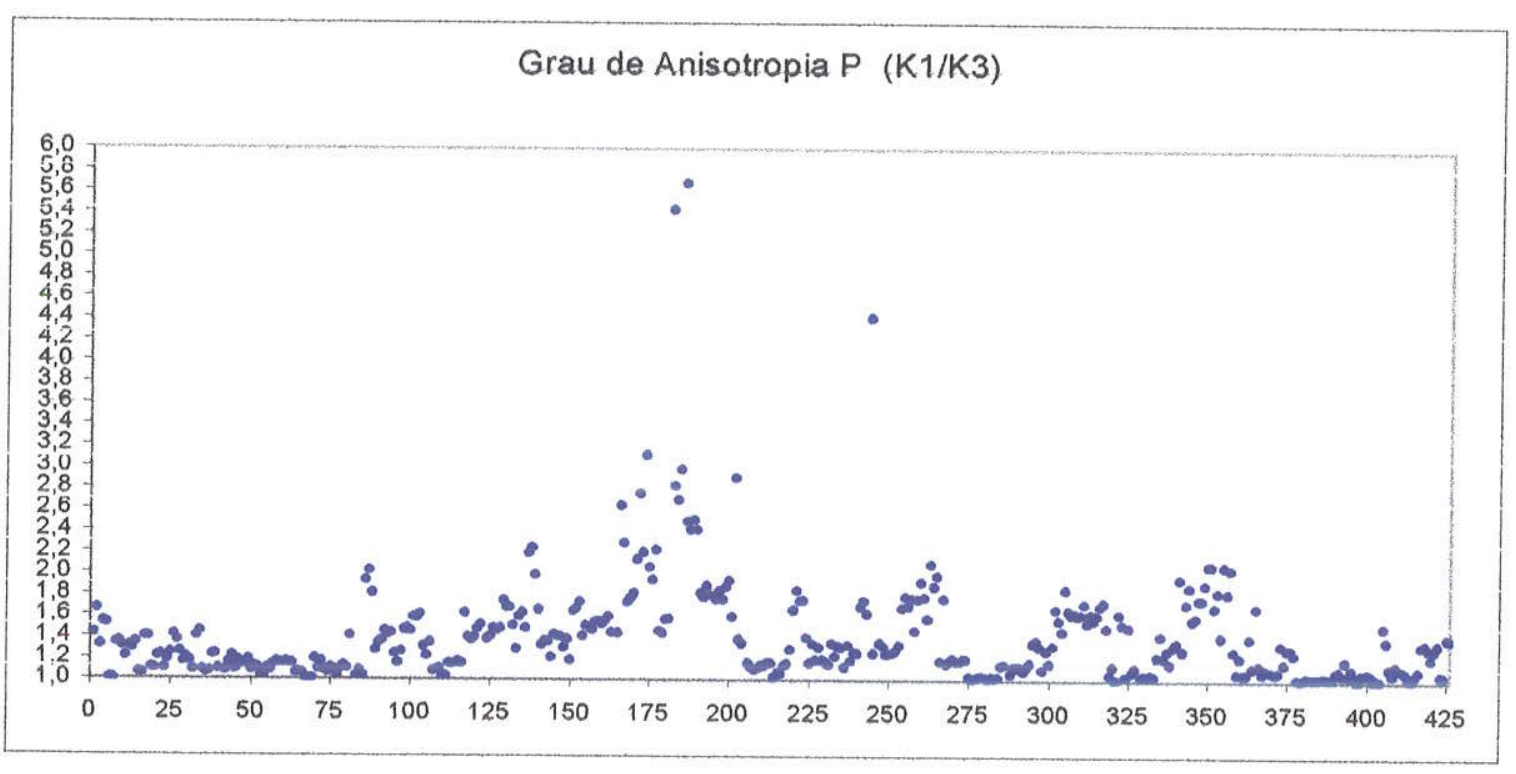

Fig.5.2. Grau de anisotropia (P) das amostras analisadas neste trabalho.

Na ordenada temos $\mathrm{P}$ (razão entre $\mathrm{K} 1$ e K3) e na abcissa temos a amostra correspondente.

Os elipsóides referentes às amostras dos gnaisses pertencentes ao Complexo Paraíba doSul $(n=110)$ apresentaram P com $80 \%$ dos valores entre 1,05 e 1,50 SI, $20 \%$ entre 1,50 e $1,95 \mathrm{SI}$, e $10 \%$ das amostras com valores de $\mathrm{P}$ menores que 1,15 SI (fig.5.3.).

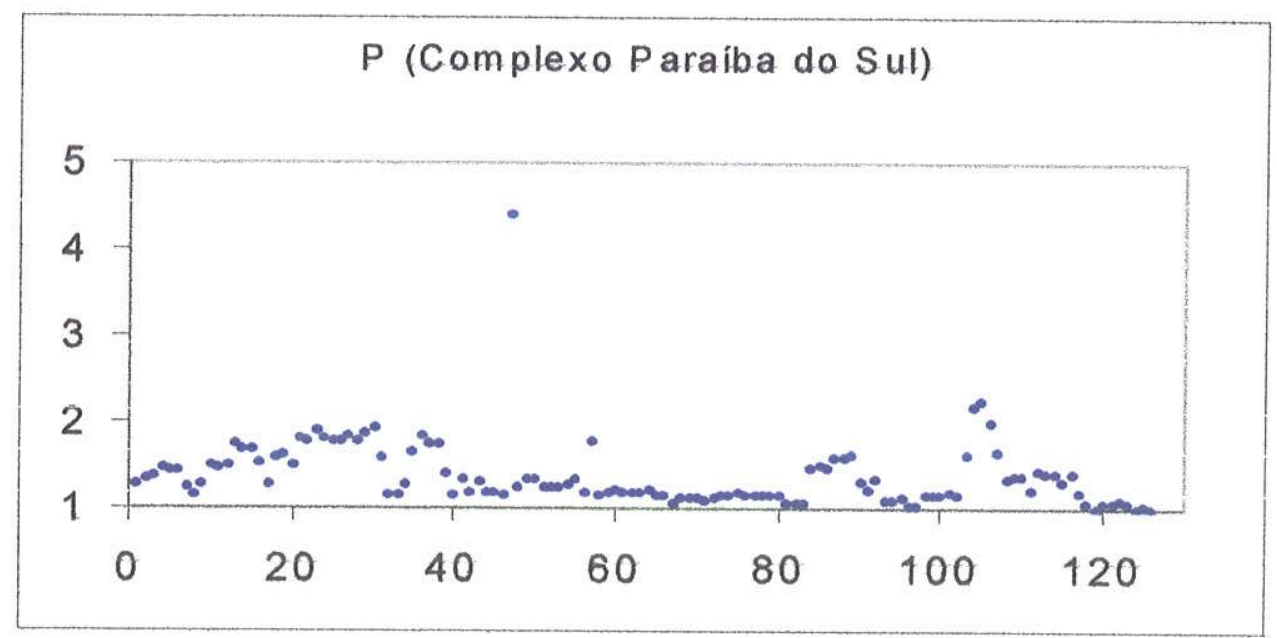

Fig.5.3. Variação do grau de anisotropia (P) nas litologias do Complexo Paraíba do Sul. 
Devido ao pequeno número de amostras, as litologias pertencentes ao Gnaisse Eugenópolis foram plotadas no mesmo gráfico que as do Complexo Paraíba do Sul, mostrando valor alto, $\mathrm{P}=4,416$.

O grau de anisotropia dos elipsóides referentes às amostras $(n=310)$ das litologias granulíticas do Complexo Juiz de Fora apresentou $60 \%$ dos valores entre 1 e $1,25 \mathrm{SI}, 25 \%$ entre 1,25 e 1,7 SI, $3 \%$ acima de 2,5 SI e o restante entre 1,7 e 2,2 SI (fig.5.4.).

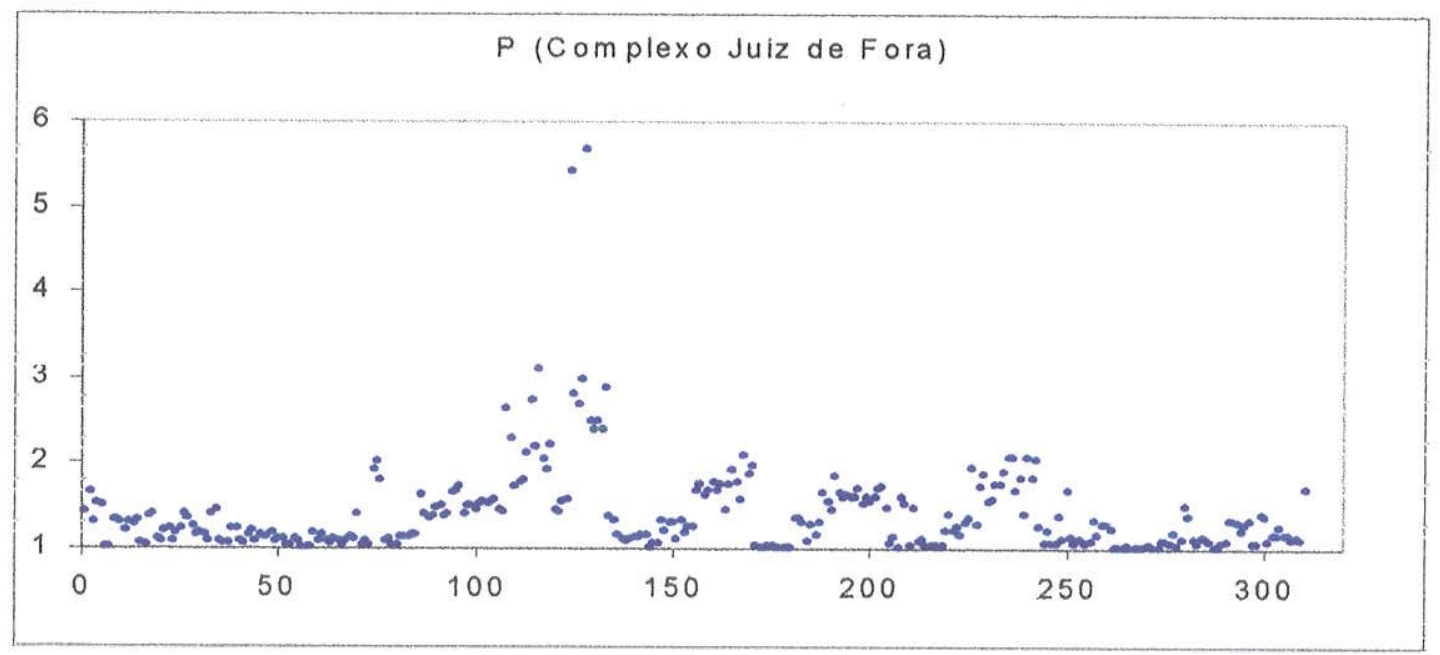

Fig.5.4. Grau de anisotropia (P) nas litologias do Complexo Juiz de Fora.

A relação entre os parâmetros $\mathrm{T}$ (parâmetro de forma) $\times \mathrm{P}^{\prime}$ (grau de anisotropia corrigido) mostra $80 \%$ das amostras com valores de $T$ positivos (fig.5.5. e fig.5.7.), caracterizando a predominância de elipsóides oblatos na área.

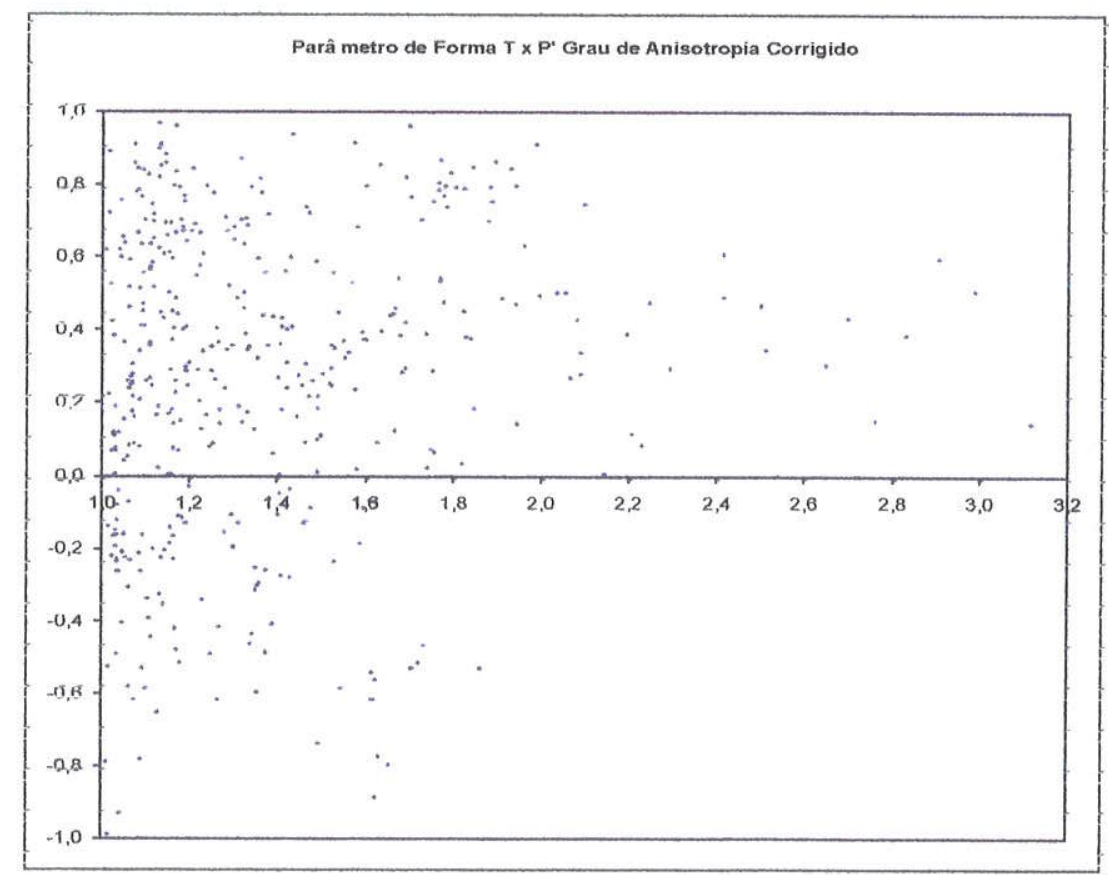

Fig.5.5. Relação entre T x P' para o conjunto das amostras da área estudada. 
T reflete a variação da forma do elipsóide de ASM e P' reflete o grau de anisotropia. A associação destes parâmetros reflete a anisotropia da fábrica magnética das amostras analisadas. Valores de $\mathrm{T}$ positivos caracterizam elipsóides oblatos e valores negativos, elipsóides prolatos. Elipsóides oblatos caracterizam anisotropia planar maior que a anisotropia linear, $\mathrm{F}>\mathrm{L}$.

A plotagem do parâmetro T (parâmetro de forma) das amostras da área mostra $75 \%$ destas com valores positivos (fig.5.6.).

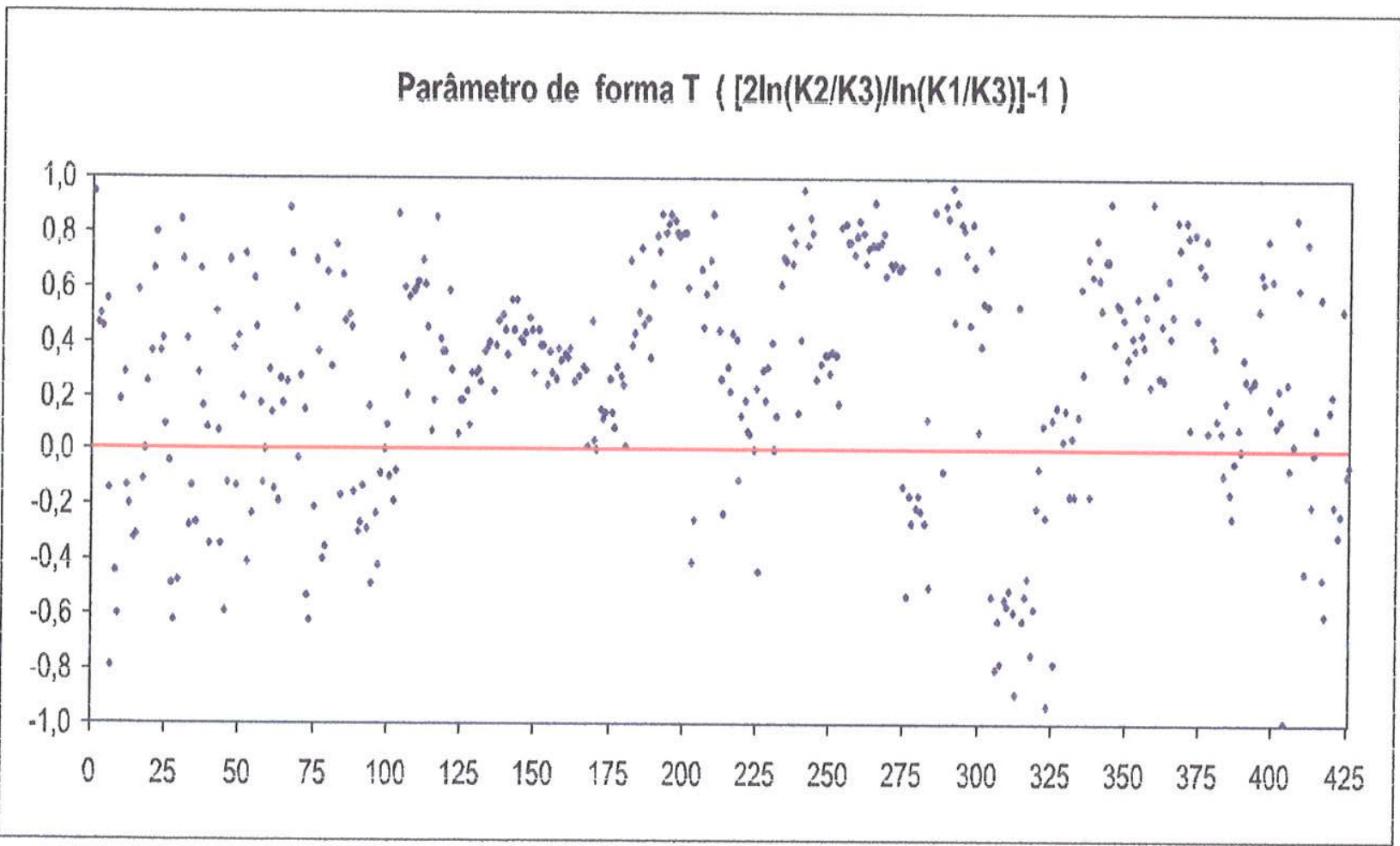

Fig.5.6. Plotagem do parâmetro de forma $(T)$ das amostras da área estudada.

T reflete a forma do elipsóide de ASM para cada amostra analisada. Tpositivo = elipsóides oblatos, $T$ negativo $=$ elipsóides prolatos .

Os valores exatos de T para cada amostra estão tabulados em Tab.5.1.

Tanto mais afastado do zero, maior a anisotropia (deformação) do elipsóide para a amostra analisada.

Para cada afloramento analisado por ASM foi elaborado um gráfico de $\mathrm{T} \times \mathrm{P}^{\prime}$ (fig.5.7.), permitindo analisar o comportamento do elipsóide de ASM (oblato ou prolato) em cada ponto e de cada cilindro estudado, caracterizando a anisotropia da fábrica magnética em detalhe.

Estes gráficos (fig.5.7., gráficos 1 a 48) foram analisados em conjunto com os estereogramas de atitudes magnéticas (fig.5.12.). 


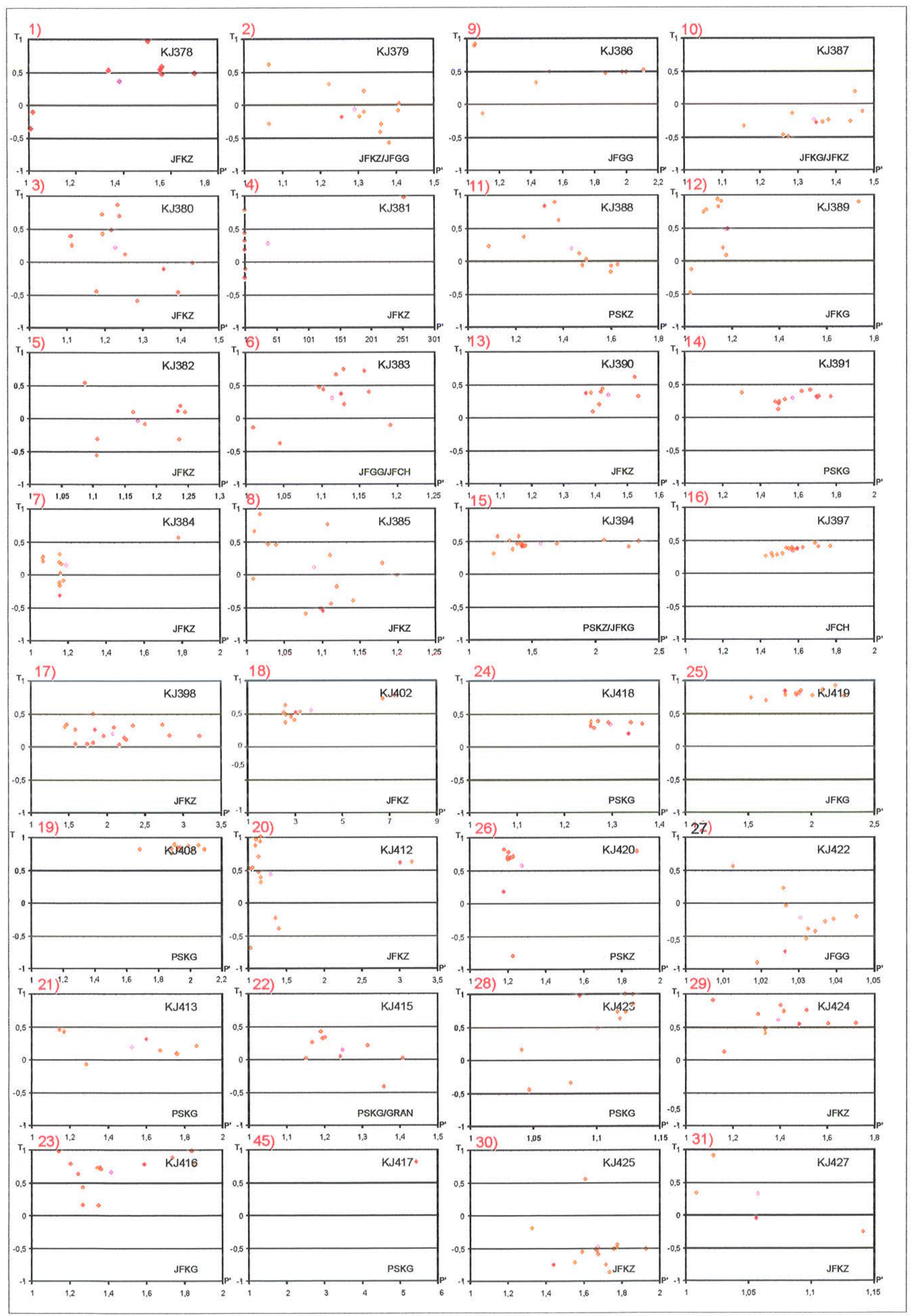

Fig.5.7. Gráficos dos parâmetros $T$ x P'referentes a todos os afloramentos da área. 


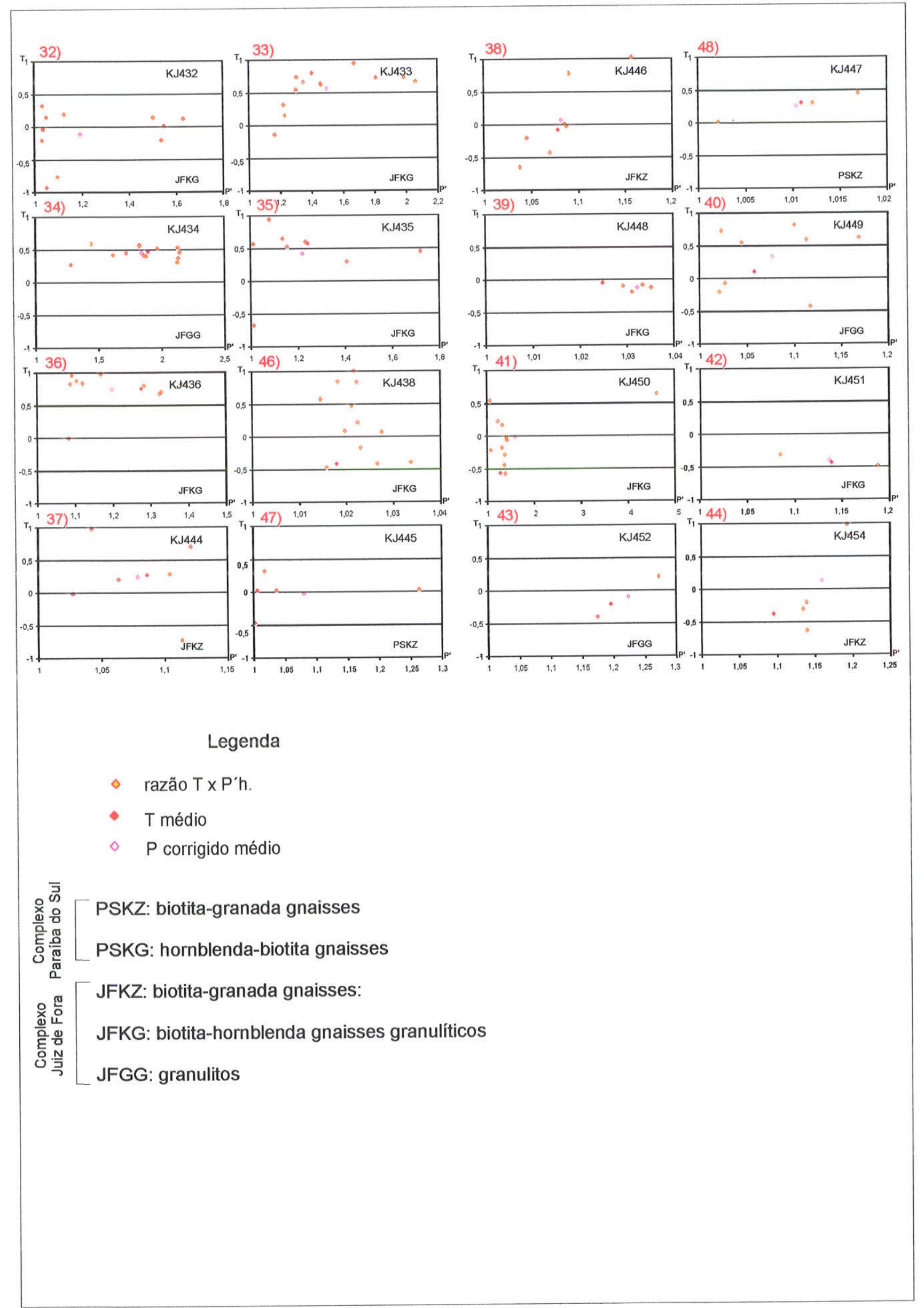

Continuação da fig.5.7. Gráficos dos parâmetros T x P'referentes a todos os afloramentos da área. 
A plotagem, em gráfico de dispersão, da relação entre os parâmetros $L$ (anisotropia linear, K1/K2) e F (anisotropia planar, K2/K3), relacionada ao parâmetro de Flinn, mostrou a predominância da fábrica planar no conjunto das amostras da área, representada por valores plotando abaixo da linha de inclinação do gradiente unitário, o que caracteriza elipsóides oblatos (fig.5.8.).

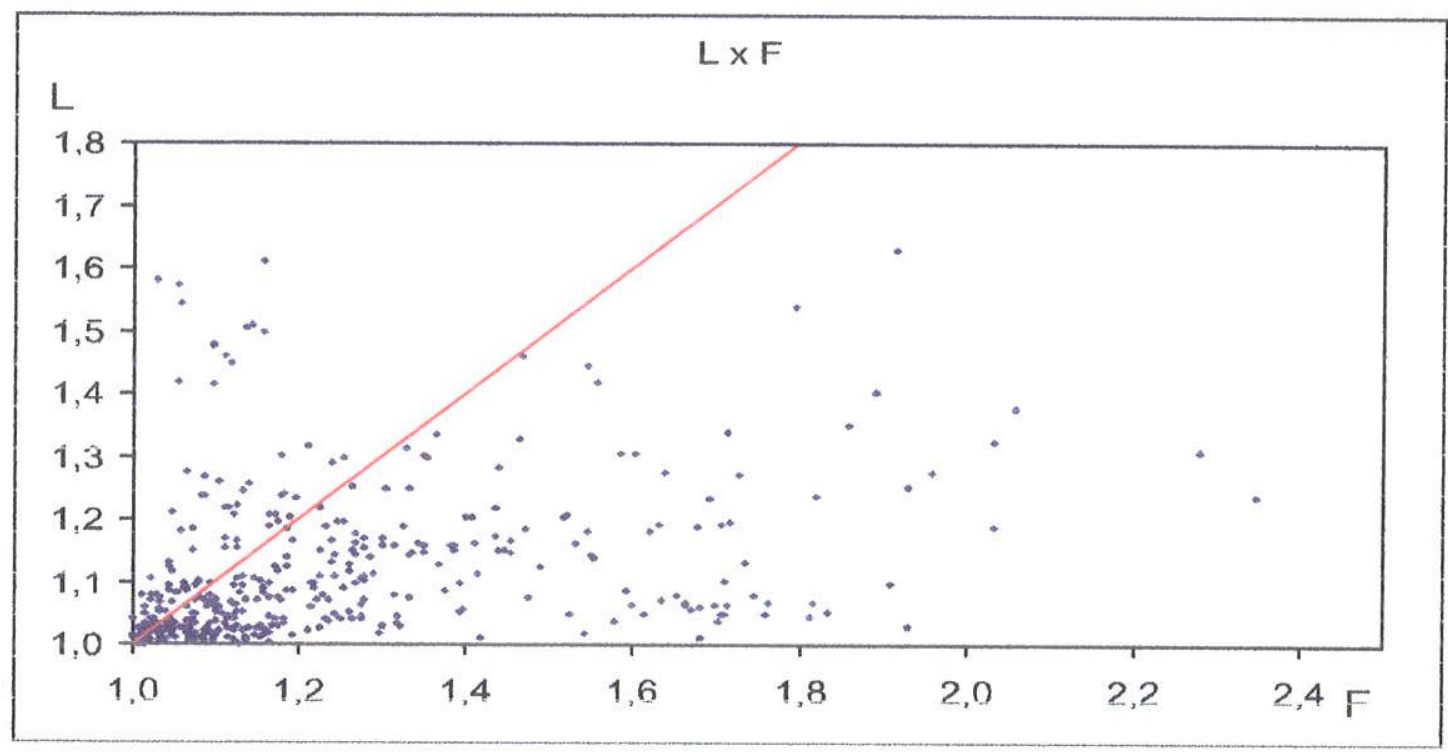

Fig. 5.8. Plotagem de $L(K 1 / K 2)$ versus $F(K 2 / K 3)$ das amostras (médias por afloramento) da área estudada. Similar à plotagem de Flinn. Correlaciona anisotropia linear com anisotropia planar.

A porcentagem de anisotropia $(H)$ mostra que os elipsóides de ASM possuem eixos bem definidos e, estatísticamente bem agrupados. $\mathrm{H}$ para o conjunto das amostras da área está em torno de $60 \%$ (fig.5.9.), similar à $\mathrm{H}$ nas litologias do Complexo Paraíba do Sul (fig.5.10.), enquanto nas litologias do Complexo Juiz de Fora, atinge $80 \%$ (fig.5.11.).

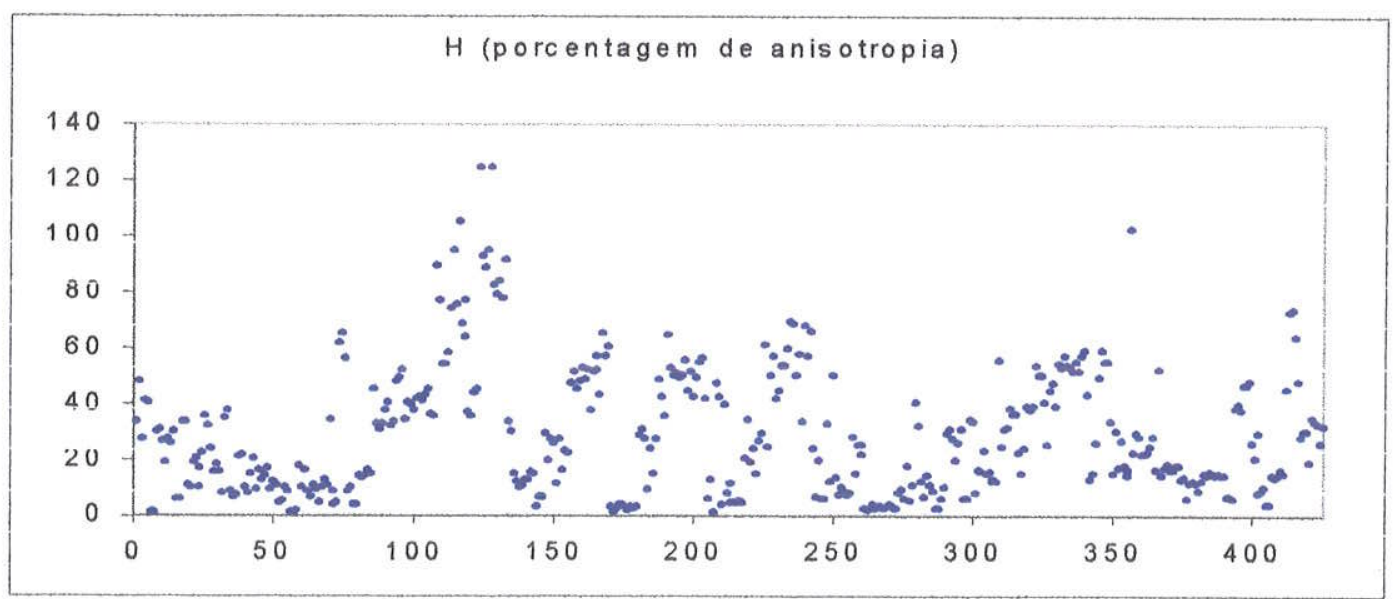

Fig. 5.9. Porcentagem de anisotropia $(\mathrm{H} \times 100)$ das amostras da área. 


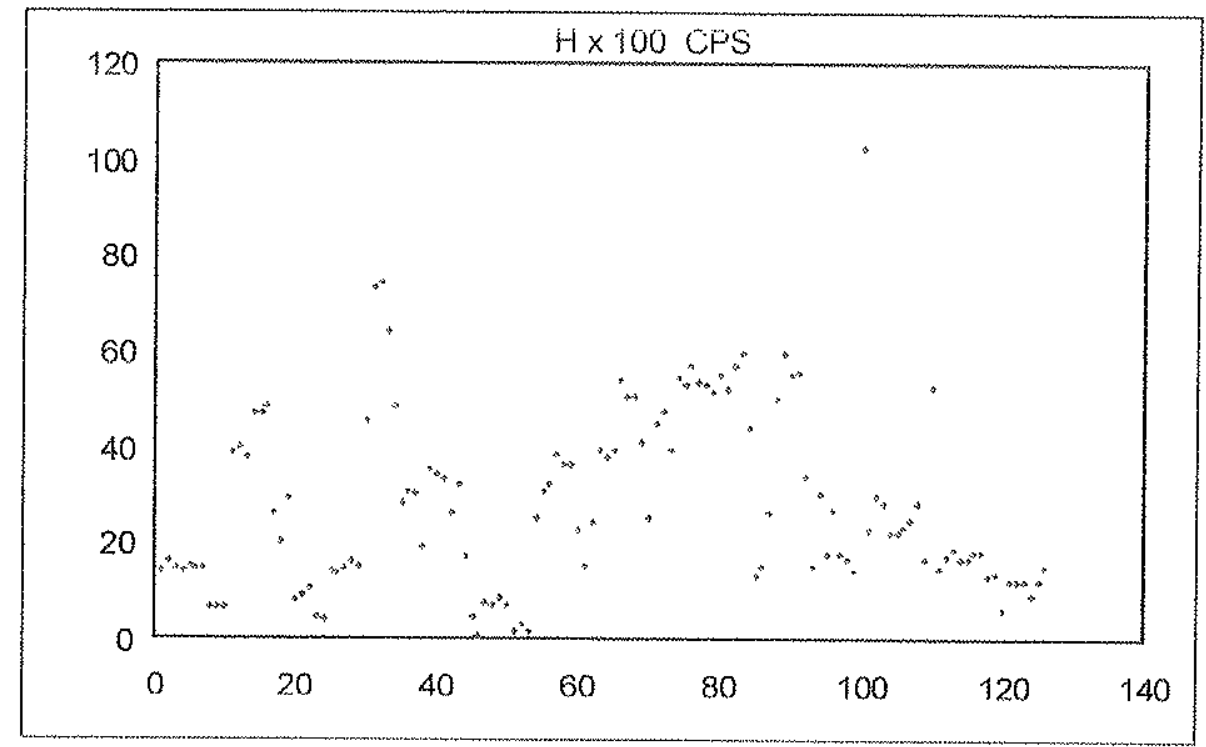

Fig. 5.10. Porcentagem de anisotropia $(H \times 100)$ das amostras do Complexo Paraiba do SuH.

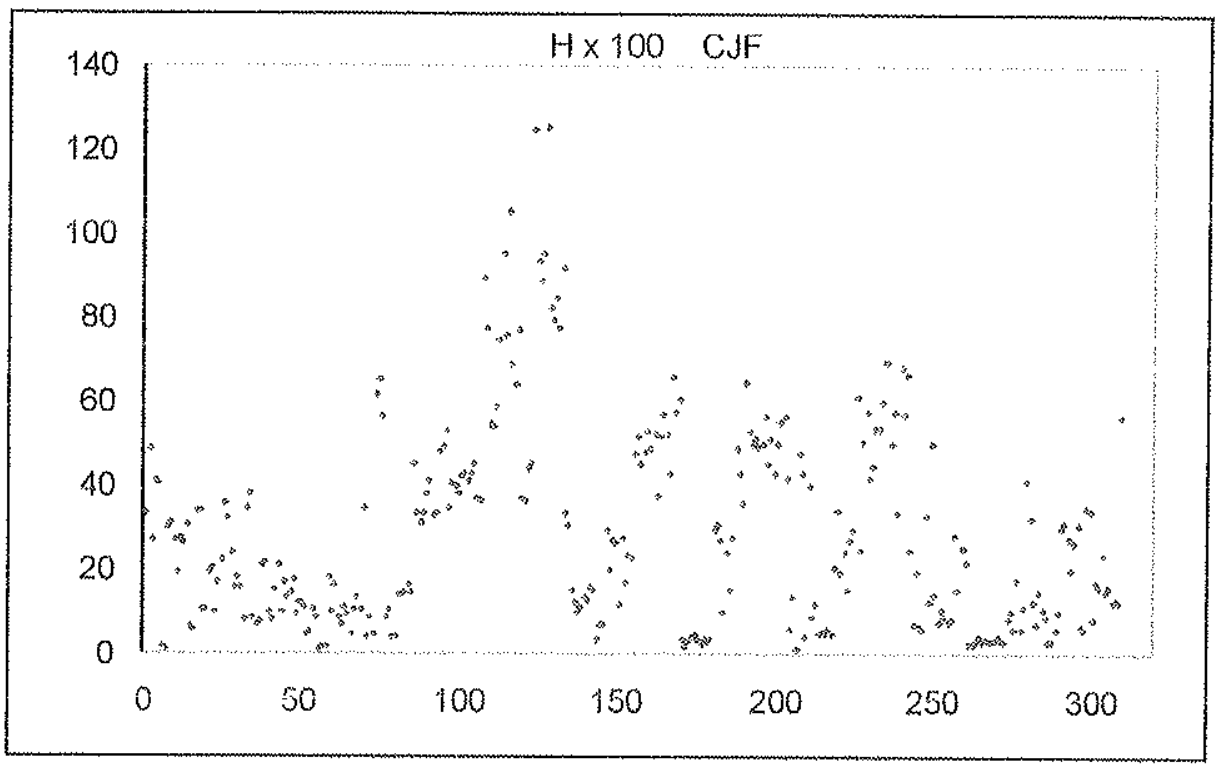

Fig. 5.11. Porcentagem de anisotropia (Hx100) das amostras do Complexo Juiz de Fora.

Foram elaborados estereogramas representativos de cada afloramento (fig.5.12.) que mostram os autovetores $\mathrm{K} 1, \mathrm{~K} 2$ e $\mathrm{K} 3$ de cada cilindro analisado, plotados segundo suas coordenadas geográficas (veja tab.5.1.), com as respectivas elipses de confiança.

De maneira geral, estes autovetores mostram concentração estatística regular de suas coordenadas geográficas, com porcentagens de confiança (na forma de elipses de confiança, menor tamanho indica maior confiança) variando de 60 a $70 \%$ na maior parte da área e acima de $85 \%$ em cerca de $30 \%$ dos afloramentos analisados. 


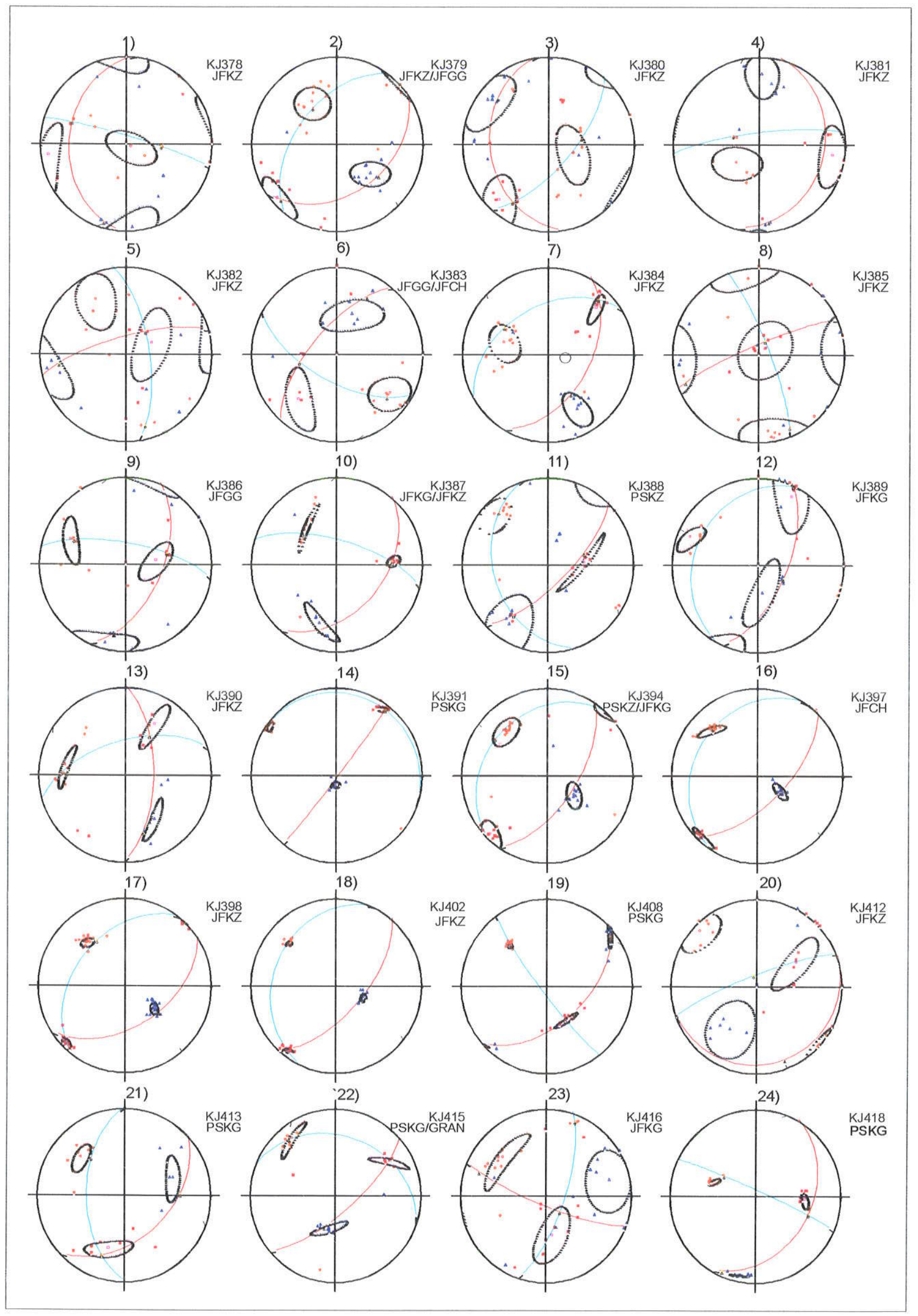

Fig. 5.12. Estereogramas representativos de cada afloramento analisado pela ASM. detalhes no texto. 


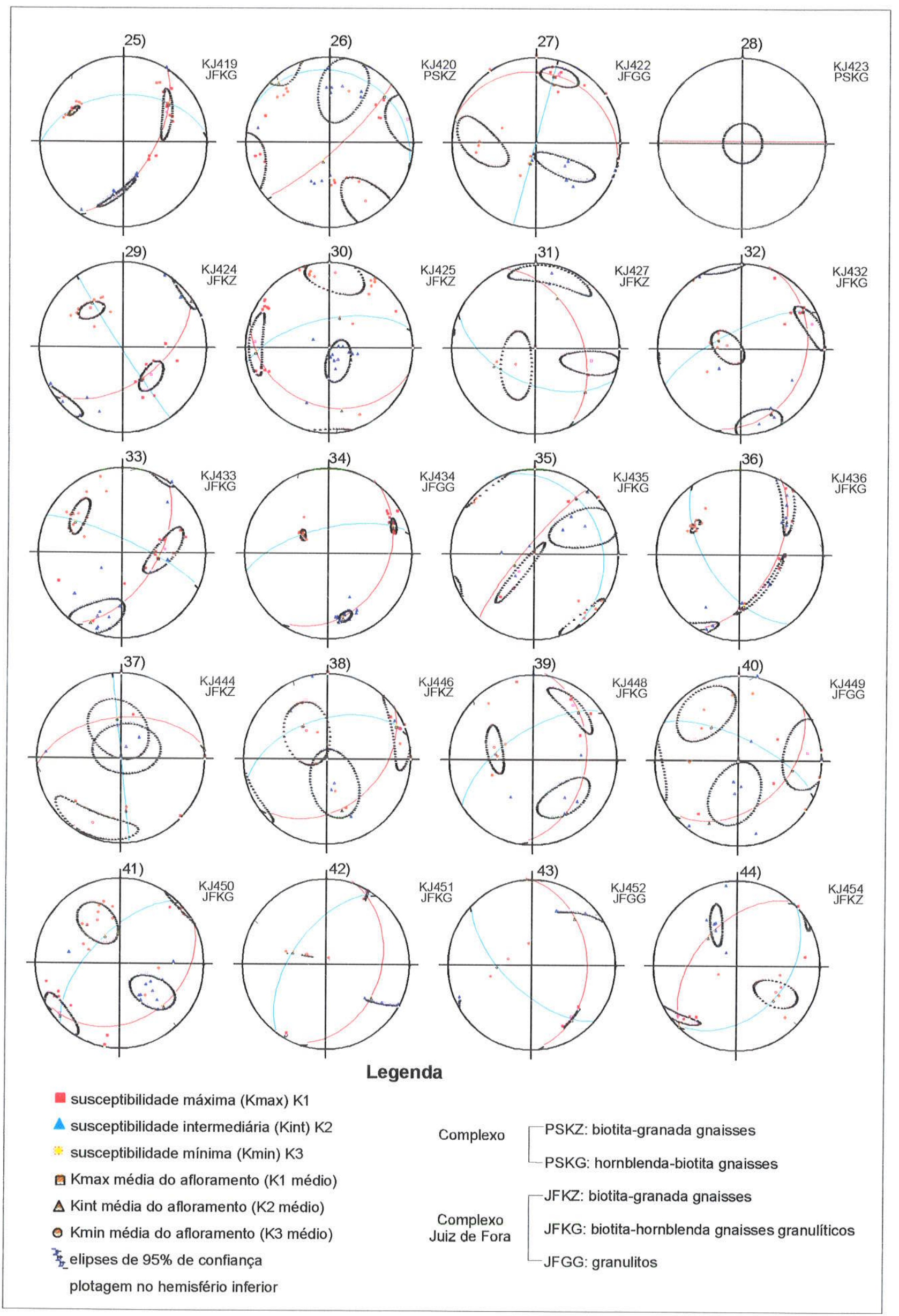

Continuação da fig. 5.12. Estereogramas representativos de cada afloramento analisado pela ASM. detalhes no texto. 
Os afloramentos que apresentaram estereogramas com maior dispersão das atitudes magnéticas (fig.5.12. est. $3,8,20,39$ e 40) estão localizados em áreas distais ao plano de deslocamento principal da zona de cisalhamento, no centro preservado dos blocos delimitados por estes falhamentos e/ou onde ocorrem óxidos e sulfetos secundários, como goethita (aff. KJ385, fig.5.12., est. 8.) e pirrotita (afl. KJ448, fig.5.12., est. 39.).

Os estereogramas com agrupamento estatístico elevado das atitudes magnéticas (fig.5.12. est. $7,9,10,14,15,16,17,18,19,22,24,25,34,36,42,43,44$ ) representam afloramentos muito próximos e/ou sobre a zona de cisalhamento e falhamentos direcionais que ocorrem na área ou, onde ocorre magnetita (e.g. fig.5.12., est.7, 9, 24 e 25.).

Em alguns casos (e.g. fig.5.12., est.26., est. 40.) houve dispersão estatística dos eixos, em estereogramas representando rochas que contém minerais fortemente magnéticos como magnetita e pirrotita. A explicação sugerida seria a superposição de fábricas magnéticas, uma devida ao óxido primário e outra devida ao sulfeto secundário.

Estereogramas com forte agrupamento estatístico de $\mathrm{K} 1, \mathrm{~K} 2$ e $\mathrm{K} 3$ apresentaram relação $T \times P^{\prime}$, que caracteriza a anisotropia da fábrica magnética, com predominância de elipsóides oblatos (compare fig.5.7., grafs. 14, 17 e 18 com fig.5.12., est. 14, 17 e 18.).

Estereogramas com dispersão média ou forte de $\mathrm{K} 1, \mathrm{~K} 2$ e $\mathrm{K} 3$ apresentaram relaçäo T $\times$ P'variável. A anisotropia planar (predominância de elipsóides oblatos) ocorre em poucos afloramentos (compare fig.5.7., grafs. 9 e 23. com fig.5.12, est. 9 e 23.) e, a anisotropia linear (predominância de elipsóides prolatos) também ocorre em poucos afloramentos (compare fig.5.7., grafs. 30,38 e 39. com fig.5.12, est. 30, 38 e 39).

Na maioria dos afloramentosonde ocorre dispersão, nas coordenadas geográficas de $\mathrm{K} 1, \mathrm{~K} 2$ e $\mathrm{K} 3$, foi verificado que os elipsóides mostram fábrica mixta, com elipsóides oblatos e prolatos, num mesmo afloramento. Uma hipótese para este fato seria que, na análise de rocha bandada, alguns cilindros representam apenas a matriz quartzo feldspática, enquanto outros amostram a banda máfica, onde os minerais magnéticos ocorrem. A superposição de fábricas magnéticas é a hipótese mais sugerida pelos autores, nestes casos, como em Borradaile, 1991, Benn et al., 1991 e outros.

A susceptibilidade média - Km (Ellwood et al., 1988) apresentada pelas amostras da área tem $70 \%$ de seus valores distribuídos no intervalo entre 0,01 a $0,03 \mathrm{SI}$, aproximadamente (tab.5.1.) e o restante entre 0,03 e $0,25 \mathrm{SI}$, compativeis com valores e variações relativas obtidos em rochas metamórficas de alto grau, em outras regiōes (Shive \& Fountain, 1988; Williamns et al., 1986; Benn et al., 1991), sugestivos de contribuição de matriz paramagnética (princ. biotita, homblenda) responsável pelos valores menores, $e$ minerais ferromagnéticos, (princ. magnetita) responsáveis pelos valores mais altos. 


\subsection{Interpretaça discussão dos dados}

Flinn introduziu o conceito de elipsóide de fábrica, que varia em forma de oblato, para a dispersão dos eixos em um plano (fábrica planar, foliação \$), devida à achatamento, a prolato, para a dispersão dos eixos sobre uma direção (fábrica linear, lineação L), devida à constriç̧ão.

No esquema de Flinn, a relação entre $L-S$, em conexão com dimensões alinhadas de objetos, define uma forma achatada ou elipsóide oblato $\mathrm{S}$, quando $\mathrm{S} 1=\mathrm{S} 2>\mathrm{S} 3$ e, 0 encurtamento normal à S3 é compensado por extensão proporcional ao longo de S1 e S2 $e$, define uma forma alongada ou elipsóide prolato $L$, quando $S 1>S 2=S 3$, a extensão paralela à S1 é compensada por encurtamento proporcional, ao longo de S2 e S3.

Na deformação plana, a extensão ao longo de uma direção é compensada por achatamento normal à direção de estiramento, não ocorre nem encurtamento nem estiramento ao longo da direção intermediária (sem variação de volume), caracterizando um elipsóide triaxial, onde $\mathrm{S} 2=\mathrm{S} 1$, e $\mathrm{S} 1>\mathrm{S} 2>\mathrm{S} 3$.

A ASM é expressa através de um elipsóide, cujos eixo máximo (K1) é paralelo à lineaçăo magnética e, o eixo mínimo (K3) é perpendicular ao plano de foliação magnética, portanto, perpendicular ao plano $\$ 1$ - $\$ 2$ e, consiste numa importante ferramenta para estudos de petrofábrica, pois possibilita estimar direções do alinhamento preferencial de minerais de forma integrada, rápida e precisa, fornecendo informações sobre a história cinemática das rochas.

Sanderson \& Marchini (1984), trabalhando no conceito de transpressão associado ao diagrama de Flinn, colocaram que o regime de deformação compressiva é caracterizado por elipsóides oblatos, enquanto o regime transtrativo é caracterizado por elipsóides prolatos, sendo o achatamento, devido ao cisalhamento puro, normal ao plano de cisalhamento, predominante na transpressão e, o estiramento ao longo do plano $\$ 1 / \$ 2$, devido ao cisalhamento simples, predominante na transtração.

A correlação entre o elipsóide de deformação e o elipsóide de ASM pode ser feita com validade, no intervalo de encurtamento entre $20-75 \%$, no cisalhamento puro. Com esta restrição e, considerando a litologia, grau de metamorfismo, mineralogia e mecanismos de deformação, as direções preferenciais, definidas através da ASM, podem ser consideradas coaxiais com as principais direções do elipsóide de deformação (Borradaile, 1991). 
A fábrica magnética das rochas estudadas é devida à contribuição de minerais ferromagnéticos e paramagnéticos, como magnetita, pirrotita, hematita alto titânio, ilmenita, biotita, piroxênio, e anfibólio.

O estudo petrográfico das litologias pertencentes aos Complexo Juiz de Fora e Paraiba do Sul evidenciou a ocorrência frequente de magnetita, hematita e biotita, com altos teores de titânio, em cristais alongados $e$, muitas vezes orientados, em fraturas de outros cristais, paralelos à foliação principal.

Esta assembléia é confirmada pelos dados petrográficos apresentados por Oliveira $(1980,1981)$ para amostras, em afloramentos localizados nos setores central e norte, da área e, em análises WDS e EDS, em amostras de afloramentos do setor sul da área, por Porcher (1997).

Trabalhos realizados por Raposo \& Egydio - Silva, 2001; Egydio - Silva et al, 2002 e Bascou et al., 2002, indicam a hematita alto - titânio, magnetita e pirrotita como responsáveis pela fábrica magnética, com contribuição de minerais paramagnéticos, confirmando a mineralogia magnética verificada pelos dados obtidos nesta dissertação, através dos métodos convencionais, em amostras localizadas em afloramentos da área.

A plotagem da porcentagem de anisotropia - H evidenciou forte anisotropia nos elipsóides magnéticos, em torno de $60 \%$ para o conjunto de amostras da área (fig.5.9), similar nas amostras pertencentes ao Complexo Paraíba do Sul (fig.5.10.) e, maior porcentagem de deformação nas amostras pertencentes ao Complexo Juiz de Fora (fig.5.11.), em torno de $80 \%$.

Esta diferença de porcentagem de anisotropia sugere controle litológico, considerando que, as rochas do Complexo Paraiba do Sul apresentam óxidos e sulfetos magnéticos, como magnetita, hematita alío titânio, ilmenita e pirrotita, similares aos verificados nas amostras pertencentes ao Complexo Juiz de Fora mas, a presença destes minerais magnéticos, orientados nas fraturas do piroxênio, principalmente hematita alto titânio (determinada por Porcher, 1997), que possue anisotropia magnetocristalina forte, foi responsável pela porcentagem de anisotropia mais alta, apresentada por este conjunto litológico.

$O$ estudo do parâmetro $P$ revelou a predominância de amostras com grau de anisotropia elevado, com a maioria dos valores de P>1,15 SI (fig.5.2.), em $70 \%$ das amostras da área, denotando elipsóides fortemente anisotrópicos, uma evidência da contribuição de minerais ferromagnéticos, predominantemente magnetita, para a 
mineralogia magnética das amostras analisadas.

Valores elevados, no grau de anisotropia, são frequentemente verificados no estudo de rochas metamórficas (Ruf et al., 1988; Borradaile, 1988, 1991; Ellwod et al., 1988; Borradaile et al., 1997, 1998, 1999; Hrouda, 1982).

Valores de $P>1,15 \mathrm{SI}$ são indicativos da presença de minerais ferromagnéticos, principalmente magnetita (Benn et al., 1991) e, valores altos de P, maiores que 1,15 SI ocorrem em todas as amostras acima citadas (tab.5.1.), bem como, a presença de magnetita, pirrotita e hematita $(P>2,5)$ nas rochas foi confirmada pela petrografia (Cap.3.) e análises de microssonda (Porcher, 1997).

Estudos, utilizando métodos magnéticos para determinar a mineralogia responsável pela fábrica magnética (Raposo \& Egydio - Silva, 2001; Bascou et al., 2002), confirmam a presença de magnetita e hematita alto titânio, em rochas da área desta dissertação.

Do ponto de vista da análise cinemática, considerando que o parâmetro $P$ relaciona $\mathrm{K} 1$ com K3 e, estes eixos podem ser comparados aos do elipsóide de tensão, valores de altos de $P$ (fig.5.2.), indicativos de $K 1>K_{2}$, representando amostras com características mesoscópicas de tectonitos $L$, indicam que stress normal controlou a orientação de $K 1$, em presença de deformação coaxial localizada, confirmada pelos elipsóides oblatos que caraterizaram os afloramentos de maiores valores de $\mathbf{P}$, mesmo estando localizados no domínio direcional, verificado no setor sul da área.

O dados escalares representativos do parâmetro de forma $T$, que caracteriza a forma do elipsóide de susceptibilidade, plotado para o conjunto das amostras da área (fig.5.6.), mostrou $75 \%$ das amostras $(n=321)$ com valores de $T>0$, indicando elipsóides oblatos, caracterizando fábrica planar predominante, e $25 \%$ das amostras $(n=105)$ analisadas mostraram valores de $T<0$, indicando elipsóides prolatos.

Fato peculiar consiste em que, amostras de gnaisses granulíticos e granada gnaises miloníticos com magnetita $e$ hematita presentes na sua assembléia mineralógica $e, c o m$ lineações de estiramento bem desenvolvidas, sugestivas de elipsóides prolatos, apresentaram fábrica magnética composta de elipsóides oblatos (fig.4.4 e fig.5.7. est.14, est.15., est.16. e est.17.).

Situação similar foi verificada por Benn et al.(1991), em rochas gnáissicas arqueanas, no Canadá, reportada como controle da fábrica magnética pela presença de magnetita na rocha. Esta interpretação corrobora com a análise da mineralogia magnética das rochas em discussão (e.g. afloramentos $\mathrm{KJ} 391, \mathrm{KJ} 398$ ), mas carece de interpretação estrutural. 
Considerando que as rochas em questão apresentam magnetita $e$, que este mineral apresenta anisotropia de forma, configurando elipsóide oblato quando em presença de achatamento perpendicular à K3 (deformação coaxial), a interpretação sugerida para a fábrica de elipsóides oblatos, em rochas que configuram tectonitos L no campo, consiste na presença de cisalhamento puro puntual, no afloramento analisado, que causou achatamento perpendicular à $\$ 3$ e estiramento paralelo à K1.

A plotagem do parâmetro L (ordenada) em função de F (abcissa), similar à plotagem de Flinn (Hrouda \& Janak, 1976), embora tenha sido considerada pouco representativa da anisotropia da fábrica, por Borradaile (1991), confirmou os resultados obtidos pela plotagem de outros parâmetros, como $T \times P^{\prime}$.

Os valores obtidos pela plotagem L x F plotaram abaixo da linha de gradiente unitário (75\%), no campo dos elipsóides oblatos (fig.5.8.).

A plotagem dos parâmetros $T \times P^{\prime}$, representando o grau de anisotropia dos três eixos do elipsóide de susceptibilidade ( $P^{\prime}$, plotados na abcissa) e, representando a forma do elipsóide ( $T$, plotados na ordenada), confirmaram a predominância dos elipsóides oblatos, na maioria das amostras da área deste trabalho.

Entretanto, considerando a plotagem de cada afloramento, onde cada amostra apresenta seu elipsóide respectivo (fig.5.7.), observamos que a fábrica mista é frequente, apresentando elipsóides oblatos e prolatos num mesmo afloramento (tectonitos $\mathrm{S}-\mathrm{L}$ ) e, eventualmente ocorre elipsóides prolatos, em situação típica de área de rochas metamórficas, como a estudada neste trabalho, indicando a coexistência de cisalhamento puro e simples.

A plotagem das coordenadas escalares de $\mathrm{K} 1, \mathrm{~K} 2$ e $\mathrm{K} 3$ em estereogramas individuais, de cada afloramento (fig.5.12.) permitiu visualizar e analisar o grau de dispersão destas medidas. Elipses de confiança foram calculadas para cada direção principal.

A dispersão mostrada em alguns afloramentos (e.g. fig.5.12., est.1., est.5., est.26., est.33.) sugere a presença de superposição de fábricas, sendo também devida à ocorrência de sulfetos secundários como pirrotita, alteração e oxidação das litologias, como verificado principalmente nos ortognaisses com biotita $e$ hornblenda $e$ nos granitóides milonitizados da área. $O$ forte agrupamento de $K 1, K 2$ e $K 3$ é frequente nos 
estereogramas representativos de rochas com magnetita $e$, de afloramentos do setor sul da área, em domínio da fábrica direcional.

Os estereogramas das atitudes de foliação e lineação magnéticas apresentaram dados fortemente concordantes com os obtidos pela plotagem dos dados obtidos em campo (fig.4.5., fig.4.6., fig.4.7. e, compare fig.4.8. e fig.4.9.).

As atitudes de foliação e lineação, obtidas em campo, mostram domínios onde a lineação se apresenta paralela à direção do plano de foliação, de baixo ou alto ângulo, nos setores sul predominantemente e, localmente, nos setores central e norte.

A dispersão em guirlanda dos eixos $\mathrm{K} 1$ dos elipsóides de ASM, representantes da lineação magnética, ocorreu ao longo de um plano, N43E/59SE, sugerindo rotação e inclinação combinadas, associadas a cisalhamento simples. A direção deste grande círculo é concordante com a direção do plano médio das foliações obtidas em campo, orientado N42E/55SE (fig.4.8. e fig.4.9.).

Plotadas em diagrama de contorno, as foliações magnéticas mostraram concentração ao longo da direção N45E/59SE, plenamente concordante com o plano de foliações de campo (fig.4.8. e fig.4.9.).

As atitudes de foliação e lineação magnética obtidas, associadas aos dados de fábrica magnética, indicando a forma e localização de elipsóides prolatos ou oblatos nos afloramentos da área, possibilitaram confirmar a evolução da área sob regime transpressivo, com predominância da tectônica tangencial (fig.4.10), nos setores central e norte e, predominância de tectônica direcional, no setor sul (fig.4.11.).

A forte concordância apresentada entre as atitudes de estruturas planares e lineares obtidas em campo, com as coordenadas geográficas dos auto-vetores de ASM, associada à caracterização da fábrica, pela identificação da forma e domínios de ocorrência dos elipsóides de susceptibilidade, confirmam a Anisotropia de Susceptibilidade Magnética como importante ferramenta para análise estrutural em rochas de alto grau metamórfico, como as aflorantes na área deste estudo.

A ASM foi aplicada nos trabalhos desta dissertação, de maneira diferenciada e especifica, para visualizar o comportamento cinemático de uma área constituída de rochas metamórficas de alto grau.

A determinação dos tensores do paleostress, utilizando dados referentes às coordenadas geográficas dos auto-vetores de ASM, configura uma importante contribuição para o desenvolvimento da aplicação da técnica de ASM, em estudos relacionados à análise estrutural. 


\begin{tabular}{|c|c|c|c|c|c|c|c|c|c|c|c|c|c|c|c|c|c|}
\hline Ref. & Amostra & $A z K 1$ & $M K 1$ & $\mathrm{Az} \mathrm{K} 2$ & $M K 2$ & $A z K 3$ & $\mathrm{MK} 3$ & K1 & $K 2$ & k3 & $\mathrm{Km}$ & $H \times 100$ & $P$ & $T$ & $P^{x}$ & L & $F$ \\
\hline 1 & KJ3781AY & 039 & 03 & 132 & 41 & 306 & 48 & 0.007475 & 0.007394 & 0.005220 & 0.0067 & 33.68 & 1.432 & 0.939 & 1.507 & 1.011 & 1.417 \\
\hline 2 & $\mathrm{KJ} 3781 \mathrm{BY}$ & 242 & 00 & 335 & 19 & 127 & 68 & 0.009643 & 0.008401 & 0.005782 & 0.0079 & 48.62 & 1.668 & 0.461 & 1.703 & 1.148 & 1.453 \\
\hline 3 & KJ3782AY & 050 & 15 & 149 & 28 & 295 & 57 & 0.004095 & 0.003818 & 0.003094 & 0.0037 & 27.27 & 1.323 & 0.501 & 1.339 & 1.072 & 1.234 \\
\hline 4 & KJ3783AX & 293 & 34 & 198 & 07 & 098 & 55 & 0.080114 & 0.071104 & 0.052032 & 0.0678 & 41.45 & 1.540 & 0.447 & 1.564 & 1.127 & 1.367 \\
\hline 5 & $\mathrm{KJ} 37838 X$ & 287 & 33 & 194 & 05 & 096 & 57 & 0.081537 & 0.074213 & 0.053320 & 0.0697 & 40.49 & 1.529 & 0.557 & 1.565 & 1.099 & 1.392 \\
\hline 6 & KJ3784AY & 102 & 04 & 010 & 35 & 197 & 55 & 0.001197 & 0.001185 & 0.001176 & 0.0012 & 1.70 & 1.017 & -0.137 & 1.017 & 1.010 & 1.007 \\
\hline 7 & KJ3784BY & 301 & 01 & 034 & 64 & 211 & 26 & 0.000631 & 0.000624 & 0.000623 & 0.0006 & 1.23 & 1.012 & -0.787 & 1.014 & 1.011 & 1.001 \\
\hline 8 & KJ3791A & 191 & 00 & 281 & 40 & 100 & 50 & 0.184687 & 0.149292 & 0.137321 & 0.1571 & 30.15 & 1.345 & -0.436 & 1.358 & 1.237 & 1.087 \\
\hline 9 & KJ3791B & 189 & 00 & 090 & 37 & 294 & 51 & 0.223313 & 0.175236 & 0.164851 & 0.1878 & 31.13 & 1.355 & -0.597 & 1.380 & 1.274 & 1.063 \\
\hline 10 & KJ3792A & 255 & 09 & 153 & 53 & 351 & 36 & 0.123061 & 0.110210 & 0.093740 & 0.1090 & 26.90 & 1.313 & 0.189 & 1.315 & 1.117 & 1.176 \\
\hline 11 & KJ3792B & 245 & 17 & 127 & 55 & 345 & 29 & 0.093067 & 0.086748 & 0.076347 & 0.0854 & 19.58 & 1.219 & 0.290 & 1.223 & 1.073 & 1.136 \\
\hline 12 & KJ3793A & 048 & 02 & 140 & 46 & 316 & 44 & 0.196276 & 0.168217 & 0.149391 & 0.1713 & 27.37 & 1.314 & -0.130 & 1.315 & 1.167 & 1.126 \\
\hline 13 & $K J 3793 B$ & 053 & 07 & 150 & 46 & 317 & 43 & 0.225230 & 0.192548 & 0.173242 & 0.1970 & 26.39 & 1.300 & -0.195 & 1.303 & 1.170 & 1.111 \\
\hline 14 & KJ3793C & 049 & 07 & 148 & 51 & 313 & 38 & 0.187232 & 0.153456 & 0.138412 & 0.1597 & 30.57 & 1.353 & -0.317 & 1.360 & 1.220 & 1.109 \\
\hline 15 & KJ3794A & 042 & 14 & 138 & 26 & 286 & 60 & 0.088848 & 0.085343 & 0.083539 & 0.0859 & 6.18 & 1.064 & -0.306 & 1.065 & 1.041 & 1.022 \\
\hline 16 & KJ3794B & 225 & 23 & 111 & 44 & 334 & 38 & 0.085858 & 0.084826 & 0.080926 & 0.0839 & 5.88 & 1.061 & 0.591 & 1.065 & 1.012 & 1.048 \\
\hline 17 & KJ3795A & 239 & 13 & 129 & 55 & 337 & 32 & 0.242516 & 0.200922 & 0.172762 & 0.2054 & 33.96 & 1.404 & -0.110 & 1.406 & 1.207 & 1.163 \\
\hline 18 & KJ37958 & 237 & 18 & 131 & 39 & 346 & 46 & 0.218340 & 0.184153 & 0.155227 & 0.1859 & 33.95 & 1.407 & 0.002 & 1.408 & 1.186 & 1.186 \\
\hline 19 & KJ3801A & 221 & 11 & 129 & 07 & 007 & 77 & 0.000599 & 0.000575 & 0.000538 & 0.0006 & 10.80 & 1.115 & 0.248 & 1.116 & 1.042 & 1.070 \\
\hline 20 & KJ3801B & 219 & 08 & $3 \uparrow 2$ & 24 & 113 & 65 & 0.000552 & 0.000534 & 0.000497 & 0.0005 & 10.37 & 1.110 & 0.365 & 1.113 & 1.034 & 1.074 \\
\hline 21 & KJ3802A & 209 & 22 & 307 & 20 & 075 & 60 & 0.000587 & 0.000568 & 0.000480 & 0.0005 & 19.58 & 1.222 & 0.669 & 1.240 & 1.034 & 1.182 \\
\hline 22 & $\mathrm{KJ} 3802 \mathrm{~B}$ & 002 & 04 & 270 & 32 & 098 & 58 & 0.000942 & 0.000922 & 0.000762 & 0.0009 & 20.60 & 1.237 & 0.795 & 1.264 & 1.022 & 1.210 \\
\hline 23 & KJ3802C & 253 & 03 & 344 & 27 & 157 & 63 & 0.000554 & 0.000536 & 0.000500 & 0.0005 & 10.28 & 1.109 & 0.359 & 1.112 & 1.034 & 1.073 \\
\hline 24 & $\mathrm{KJ} 3803 \mathrm{~A}$ & 230 & 31 & 326 & 11 & 074 & 57 & 0.001046 & 0.000993 & 0.000878 & 0.0010 & 17.20 & 1.190 & 0.408 & 1.196 & 1.053 & 1.131 \\
\hline 25 & KJ38038 & 211 & 28 & 309 & 16 & 066 & 57 & 0.005221 & 0.004710 & 0.004163 & 0.0047 & 22.53 & 1.254 & 0.090 & 1.255 & 1.109 & 1.131 \\
\hline 26 & KJ3803C & 210 & 20 & 310 & 24 & 085 & 58 & 0.015357 & 0.012754 & 0.010738 & 0.0130 & 35.67 & 1.430 & -0.038 & 1.432 & 1.204 & 1.188 \\
\hline 27 & KJ3804A & 020 & 48 & 255 & 27 & 148 & 30 & 0.001308 & 0.001032 & 0.000951 & 0.0011 & 32.51 & 1.375 & -0.488 & 1.393 & 1.267 & 1.085 \\
\hline 28 & KJ3804B & 019 & 50 & 272 & 14 & 172 & 37 & 0.001041 & 0.000860 & 0.000821 & 0.0009 & 24.20 & 1.267 & -0.616 & 1.286 & 1.211 & 1.047 \\
\hline 29 & $\mathrm{KJ} 3804 \mathrm{C}$ & 016 & 49 & 270 & 13 & 170 & 38 & 0.001166 & 0.001037 & 0.000995 & 0.0011 & 16.07 & 1.172 & -0.479 & 1.179 & 1.125 & 1.042 \\
\hline 30 & KJ3805A & 228 & 14 & 112 & 59 & 325 & 27 & 0.003514 & 0.003462 & 0.002907 & 0.0033 & 18.43 & 1.209 & 0.843 & 1.235 & 1.015 & 1.191 \\
\hline 31 & KJ3805B & 212 & 35 & 084 & 41 & 325 & 29 & 0.002616 & 0.002553 & 0.002219 & 0.0025 & 16.12 & 1.179 & 0.702 & 1.194 & 1.025 & 1.150 \\
\hline 32 & KJ3811C & 090 & 46 & 348 & 11 & 248 & 42 & 0.003516 & 0.003429 & 0.003228 & 0.0034 & 8.50 & 1.089 & 0.413 & 1.092 & 1.025 & 1.062 \\
\hline 33 & $K J 3812 B$ & 083 & 21 & 176 & 07 & 283 & 68 & 0.112926 & 0.090664 & 0.080001 & 0.0945 & 34.83 & 1.412 & -0.274 & 1.410 & 1.246 & 1.133 \\
\hline 34 & KJ3812C & 078 & 23 & 172 & 09 & 283 & 65 & 0.107950 & 0.087093 & 0.073846 & 0.0896 & 38.05 & 1.462 & -0.131 & 1.465 & 1.239 & 1.179 \\
\hline 35 & KJ3813A & 294 & 04 & 027 & 30 & 197 & 60 & 0.000785 & 0.000743 & 0.000720 & 0.0007 & 8.64 & 1.090 & -0.265 & 1.091 & 1.056 & 1.032 \\
\hline 36 & KJ3813B & 105 & 07 & 010 & 39 & 203 & 50 & 0.000832 & 0.000812 & 0.000777 & 0.0008 & 6.82 & 1.071 & 0.280 & 1.072 & 1.025 & 1.045 \\
\hline 37 & KJ3813C & 086 & 15 & 349 & 26 & 202 & 59 & 0.000626 & 0.000618 & 0.000579 & 0.0006 & 7.78 & 1.082 & 0.667 & 1.088 & 1.013 & 1.068 \\
\hline 38 & KJ3821AX & 036 & 65 & 253 & 21 & 157 & 14 & 0.045749 & 0.041866 & 0.036970 & 0.0415 & 21.14 & 1.237 & 0.167 & 1.239 & 1.093 & 1.132 \\
\hline 38 & $K J 3821 B X$ & 047 & 62 & 265 & 23 & 168 & 16 & 0.068887 & 0.062256 & 0.055301 & 0.0621 & 21.86 & 1.246 & 0.078 & 1.246 & 1.107 & 1.126 \\
\hline 40 & KJ3822AX & 010 & 69 & 219 & 19 & 126 & 09 & 0.014755 & 0.013802 & 0.013354 & 0.0140 & 10.03 & 1.105 & -0.338 & 1.107 & 1.069 & 1.034 \\
\hline
\end{tabular}

Tab. 5.1. Dados de ASM. 


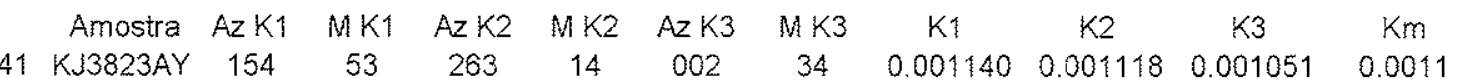

42 KJ3823BY 167

$43 \mathrm{KJ} 3823 \mathrm{CY} 180$

$44 \mathrm{KJ} 3824 \mathrm{AY} \quad 048$

$45 \mathrm{KJ} 3824 \mathrm{BY} \quad 055$

$46 \mathrm{KJ} 3831 \mathrm{~A} \quad 235$

$47 \mathrm{KJ} 3831 \mathrm{~B} 242$

48 KJ3831C 268

49 KJ3832A 015

$\begin{array}{lll}50 & K J 3832 B & 265 \\ 51 & K J 3832 C & 210\end{array}$

52 KJ3833A 194

$53 \mathrm{KJ} 3833 \mathrm{~B} \quad 003$

$54 \mathrm{KJ} 3834 \mathrm{~A} \quad 218$

$55 \quad \mathrm{KJ} 3834 \mathrm{~B} \quad 223$

$56 \quad \mathrm{KJ} 3841 \mathrm{~B} \quad 043$

$57 \mathrm{KJ} 3841 \mathrm{C} \quad 045$

58 KJ3842A 046

$59 \mathrm{KJ} 3842 \mathrm{~B} \quad 044$

$60 \mathrm{KJ} 3842 \mathrm{C} \quad 038$

$61 \mathrm{KJ} 3843 \mathrm{~A} \quad 046$

$62 \mathrm{KJ} 3843 \mathrm{~B} \quad 050$

$63 \mathrm{KJ} 3844 \mathrm{~A} \quad 069$

$64 \quad K J 38448 \quad 063$

$65 \mathrm{KJ} 3844 \mathrm{C} \quad 068$

$66 \quad \mathrm{KJ} 3853 \mathrm{~A} \quad 085$

$67 \mathrm{KJ} 38538 \quad 206$

$68 \mathrm{KJ} 3853 \mathrm{C} \quad 084$

$69 \mathrm{KJ} 3855 \mathrm{C} \quad 304$

$\begin{array}{lll}70 & K J 38558 & 054\end{array}$

$71 \mathrm{~K} J 3855 \mathrm{~A}$

$72 \mathrm{KJ} 3854 \mathrm{C} \quad 016$

$\begin{array}{lll}73 & \mathrm{KJ} 3854 \mathrm{~B} & 037\end{array}$

$74 \mathrm{KJ} 3854 \mathrm{~A} \quad 053$

$75 \mathrm{KJ} 38528 \quad 260$

$76 \mathrm{KJ} 3852 \mathrm{~A} \quad 28$

$77 \mathrm{KJ} 3851 \mathrm{C} \quad 242$

$78 \quad K J 38518 \quad 321$

79 KJ3851A 243

80 KJ3861A 046

$\begin{array}{cccc}M K 1 & A Z K 2 & M K 2 & A Z K 3 \\ 53 & 263 & 14 & 002 \\ 40 & 076 & 00 & 346 \\ 24 & 072 & 34 & 298 \\ 13 & 140 & 06 & 254 \\ 05 & 151 & 50 & 321 \\ 06 & 334 & 59 & 141 \\ 38 & 014 & 40 & 129 \\ 56 & 047 & 27 & 147 \\ 31 & 265 & 29 & 142 \\ 58 & 030 & 19 & 129 \\ 40 & 347 & 41 & 099 \\ 01 & 103 & 19 & 286 \\ 42 & 095 & 01 & 186 \\ 32 & 032 & 58 & 127 \\ 38 & 032 & 52 & 129 \\ 15 & 148 & 43 & 298 \\ 22 & 163 & 49 & 300 \\ 21 & 150 & 32 & 288 \\ 19 & 147 & 32 & 290 \\ 16 & 138 & 31 & 285 \\ 10 & 143 & 36 & 303 \\ 12 & 150 & 40 & 307 \\ 50 & 164 & 04 & 258 \\ 56 & 155 & 01 & 245 \\ 60 & 164 & 03 & 256 \\ 30 & 186 & 19 & 304 \\ 09 & 111 & 30 & 311 \\ 36 & 192 & 23 & 307 \\ 86 & 048 & 01 & 138 \\ 82 & 262 & 07 & 172 \\ 84 & 075 & 03 & 185 \\ 73 & 161 & 14 & 253 \\ 75 & 265 & 10 & 173 \\ 64 & 293 & 14 & 197 \\ 15 & 050 & 73 & 168 \\ 21 & 142 & 63 & 018 \\ 58 & 106 & 24 & 007 \\ 85 & 104 & 04 & 194 \\ 41 & 004 & 31 & 117 \\ 32 & 145 & 15 & 257 \\ & & & \end{array}$

$\begin{array}{llll}0.001140 & 0.001118 & 0.001051 & 0.0011 \\ 0.002186 & 0.002037 & 0.001878 & 0.0020\end{array}$

$\begin{array}{lllll}0.001653 & 0.001438 & 0.001343 & 0.0015\end{array}$

$\begin{array}{lllll}0.000760 & 0.000704 & 0.000691 & 0.0007\end{array}$

$\begin{array}{lllll}0.003587 & 0.003287 & 0.003034 & 0.0033\end{array}$

$\begin{array}{lllll}0.001760 & 0.001724 & 0.001538 & 0.0017\end{array}$

$\begin{array}{lllll}0.002077 & 0.001983 & 0.001793 & 0.0020\end{array}$

$\begin{array}{llll}0.002474 & 0.002242 & 0.002079 & 0.0023\end{array}$

$\begin{array}{llll}0.001013 & 0.000985 & 0.000922 & 0.0010\end{array}$

$\begin{array}{lllll}0.002612 & 0.002486 & 0.002312 & 0.0025\end{array}$

$\begin{array}{lllll}0.001549 & 0.001525 & 0.001384 & 0.0015\end{array}$

$\begin{array}{lllll}0.000266 & 0.000257 & 0.000254 & 0.0003\end{array}$

$\begin{array}{llllll}0.000342 & 0.000331 & 0.000324 & 0.0003\end{array}$

$\begin{array}{lllll}0.001216 & 0.001193 & 0.001095 & 0.0012\end{array}$

$\begin{array}{lllll}0.001949 & 0.001902 & 0.001783 & 0.0019\end{array}$

$\begin{array}{lllll}0.001955 & 0.001843 & 0.001695 & 0.0018\end{array}$

$\begin{array}{lllll}0.003799 & 0.003475 & 0.003235 & 0.0035\end{array}$

$\begin{array}{lllll}0.001640 & 0.001522 & 0.001413 & 0.0015\end{array}$

$\begin{array}{lllll}0.001637 & 0.001555 & 0.001416 & 0.0015\end{array}$

$\begin{array}{llll}0.001610 & 0.001508 & 0.001382 & 0.0015\end{array}$

$\begin{array}{lllll}0.002064 & 0.001901 & 0.001787 & 0.0019\end{array}$

$\begin{array}{lllll}0.002346 & 0.002150 & 0.002026 & 0.0022\end{array}$

$\begin{array}{lllll}0.000606 & 0.000591 & 0.000567 & 0.0006\end{array}$

$\begin{array}{llllll}0.000459 & 0.000447 & 0.000430 & 0.0004\end{array}$

$\begin{array}{lllll}0.000523 & 0.000510 & 0.000490 & 0.0005\end{array}$

$\begin{array}{lllll}0.000666 & 0.000666 & 0.000657 & 0.0007\end{array}$

$\begin{array}{lllll}0.000626 & 0.000625 & 0.000616 & 0.0006\end{array}$

$\begin{array}{lllll}0.000707 & 0.000704 & 0.000694 & 0.0007\end{array}$

$\begin{array}{lllll}0.002936 & 0.002675 & 0.002449 & 0.0027\end{array}$

$\begin{array}{lllll}0.001287 & 0.001239 & 0.001161 & 0.0012\end{array}$

$\begin{array}{lllll}0.001382 & 0.001289 & 0.001172 & 0.0013\end{array}$

$\begin{array}{lllll}0.003551 & 0.003317 & 0.003248 & 0.0034\end{array}$

$\begin{array}{lllll}0.003071 & 0.002900 & 0.002861 & 0.0029\end{array}$

$0.002716 \quad 0.002539 \quad 0.002428 \quad 0.0026$

$\begin{array}{lllll}0.000753 & 0.000743 & 0.000685 & 0.0007\end{array}$

$\begin{array}{llll}0.000157 & 0.000155 & 0.000150 & 0.0002\end{array}$

$\begin{array}{llll}0.000617 & 0.000574 & 0.000556 & 0.0006\end{array}$

$\begin{array}{lllll}0.000173 & 0.000159 & 0.000152 & 0.0002\end{array}$

$\begin{array}{llll}0.000050 & 0.000049 & 0.000045 & 0.0000\end{array}$

$\begin{array}{llll}0.040136 & 0.035551 & 0.028203 & 0.0346\end{array}$

$\begin{array}{cccccc}H & \mathrm{P} & \mathrm{T} & \mathrm{P}^{\prime} & \mathrm{L} & \mathrm{F} \\ 8.05 & 1.084 & 0.513 & 1.088 & 1.020 & 1.063 \\ 15.13 & 1.164 & 0.071 & 1.164 & 1.073 & 1.085 \\ 21.00 & 1.231 & -0.343 & 1.236 & 1.150 & 1.071 \\ 9.71 & 1.101 & -0.587 & 1.107 & 1.079 & 1.020 \\ 16.77 & 1.182 & -0.114 & 1.183 & 1.098 & 1.077 \\ 13.30 & 1.145 & 0.696 & 1.157 & 1.021 & 1.122 \\ 14.58 & 1.159 & 0.374 & 1.163 & 1.047 & 1.106 \\ 17.46 & 1.190 & -0.129 & 1.191 & 1.103 & 1.079 \\ 9.42 & 1.100 & 0.415 & 1.102 & 1.028 & 1.069 \\ 12.11 & 1.129 & 0.190 & 1.130 & 1.050 & 1.075 \\ 11.08 & 1.119 & 0.718 & 1.129 & 1.016 & 1.101 \\ 4.62 & 1.047 & -0.406 & 1.048 & 1.033 & 1.014 \\ 5.33 & 1.055 & -0.226 & 1.055 & 1.033 & 1.021 \\ 10.43 & 1.111 & 0.634 & 1.119 & 1.019 & 1.090 \\ 8.88 & 1.094 & 0.450 & 1.097 & 1.025 & 1.067 \\ 14.23 & 1.154 & 0.172 & 1.155 & 1.061 & 1.087 \\ 16.10 & 1.174 & -0.112 & 1.175 & 1.093 & 1.074 \\ 14.84 & 1.160 & 0.001 & 1.160 & 1.077 & 1.077 \\ 14.36 & 1.156 & 0.292 & 1.158 & 1.053 & 1.098 \\ 15.25 & 1.166 & 0.142 & 1.166 & 1.068 & 1.091 \\ 14.46 & 1.155 & -0.142 & 1.156 & 1.086 & 1.064 \\ 14.69 & 1.158 & -0.187 & 1.159 & 1.091 & 1.061 \\ 6.68 & 1.069 & 0.258 & 1.070 & 1.025 & 1.043 \\ 6.62 & 1.069 & 0.176 & 1.069 & 1.028 & 1.040 \\ 6.50 & 1.067 & 0.252 & 1.068 & 1.025 & 1.042 \\ 1.44 & 1.015 & 0.890 & 1.016 & 1.001 & 1.014 \\ 1.58 & 1.016 & 0.723 & 1.017 & 1.002 & 1.014 \\ 1.84 & 1.019 & 0.525 & 1.019 & 1.004 & 1.014 \\ 18.12 & 1.199 & -0.028 & 1.199 & 1.098 & 1.092 \\ 10.24 & 1.108 & 0.270 & 1.110 & 1.038 & 1.068 \\ 16.38 & 1.179 & 0.150 & 1.180 & 1.072 & 1.099 \\ 9.00 & 1.093 & -0.531 & 1.098 & 1.071 & 1.021 \\ 7.12 & 1.073 & -0.618 & 1.078 & 1.059 & 1.014 \\ 11.24 & 1.119 & -0.203 & 1.119 & 1.070 & 1.046 \\ 9.34 & 1.099 & 0.704 & 1.107 & 1.014 & 1.084 \\ 4.85 & 1.050 & 0.367 & 1.051 & 1.016 & 1.034 \\ 10.52 & 1.110 & -0.394 & 1.113 & 1.076 & 1.032 \\ 13.27 & 1.141 & -0.353 & 1.144 & 1.093 & 1.044 \\ 10.81 & 1.116 & 0.651 & 1.124 & 1.019 & 1.095 \\ 34.46 & 1.423 & 0.312 & 1.433 & 1.129 & 1.261\end{array}$

Tab. 5.1. Dados de ASM.

Coordenadas geográficas e escałares de $\mathrm{K} 1, \mathrm{~K} 2$ e $\mathrm{K} 3$, valores de susceptibilidade e parâmetros de anisotropia magnética. 


\begin{tabular}{|c|c|c|c|c|c|c|c|c|c|c|c|c|c|c|c|c|c|}
\hline & Amostra & $A z K 1$ & MK1 & $A z K 2$ & $M K 2$ & $\mathrm{~A} Z \mathrm{~K} 3$ & $\mathrm{MK} 3$ & K1 & $\mathrm{K} 2$ & K3 & $\mathrm{Km}$ & $\mathrm{H}$ & $P$ & $T$ & $P^{\prime}$ & $L$ & $F$ \\
\hline 81 & KJ3862B & 062 & 58 & 177 & 15 & 275 & 28 & 0.000812 & 0.000808 & 0.000780 & 0.0008 & 4.03 & 1.041 & 0.756 & 1.045 & 1.005 & 1.036 \\
\hline 82 & KJ3863A & 172 & 69 & 038 & 15 & 304 & 15 & 0.001592 & 0.001510 & 0.001454 & 0.0015 & 9.06 & 1.095 & -0.163 & 1.095 & 1.054 & 1.039 \\
\hline 83 & KJ3863B & 059 & 53 & 238 & 37 & 328 & 00 & 0.000974 & 0.000965 & 0.000928 & 0.0010 & 4.79 & 1.049 & 0.640 & 1.053 & 1.009 & 1.040 \\
\hline 84 & KJ3864A & 079 & 51 & 192 & 18 & 295 & 34 & 0.167865 & 0.140814 & 0.086422 & 0.1317 & 61.84 & 1.942 & 0.471 & 2.002 & 1.192 & 1.629 \\
\hline 85 & $K J 3864 B$ & 076 & 50 & 190 & 19 & 293 & 34 & 0.153272 & 0.128401 & 0.075315 & 0.1190 & 65.51 & 2.035 & 0.502 & 2.111 & 1.194 & 1.705 \\
\hline 86 & KJ3864C & 081 & 47 & 189 & 16 & 292 & 38 & 0.109358 & 0.092703 & 0.059959 & 0.0873 & 56.56 & 1.824 & 0.450 & 1.869 & 1.180 & 1.546 \\
\hline 87 & $\mathrm{KJ} 3871 \mathrm{~A}$ & 089 & 28 & 200 & 34 & 329 & 43 & 0.000662 & 0.000573 & 0.000516 & 0.0006 & 25.02 & 1.283 & -0.155 & 1.285 & 1.155 & 1.111 \\
\hline 88 & KJ3871B & 088 & 28 & 200 & 35 & 320 & 42 & 0.000801 & 0.000657 & 0.000590 & 0.0007 & 30.99 & 1.359 & -0.294 & 1.366 & 1.219 & 1.114 \\
\hline 89 & $\mathrm{KJ} 3871 \mathrm{C}$ & 087 & 29 & 214 & 46 & 339 & 29 & 0.000598 & 0.000490 & 0.000435 & 0.0005 & 32.05 & 1.374 & -0.261 & 1.380 & 1.222 & 1.124 \\
\hline 90 & $\mathrm{KJ} 3872 \mathrm{~A}$ & 085 & 34 & 187 & 17 & 298 & 51 & 0.001021 & 0.000823 & 0.000696 & 0.0008 & 38.38 & 1.467 & -0.127 & 1.470 & 1.241 & 1.182 \\
\hline 31 & KJ3872B & 084 & 34 & 187 & 18 & 300 & 50 & 0.000647 & 0.000515 & 0.000452 & 0.0005 & 36.24 & 1.431 & -0.280 & 1.439 & 1.258 & 1.138 \\
\hline 2 & KJ3872C & 090 & 34 & 192 & 18 & 305 & 51 & 0.000843 & 0.000722 & 0.000583 & 0.0007 & 36.29 & 1.446 & 0.163 & 1.450 & 1.167 & 1.239 \\
\hline 93 & KJ3873A & 090 & 50 & 319 & 29 & 214 & 25 & 0.000764 & 0.000647 & 0.000611 & 0.0007 & 22.69 & 1.250 & -0.491 & 1.262 & 1.181 & 1.058 \\
\hline 94 & $K J 38738$ & 085 & 43 & 212 & 33 & 324 & 30 & 0.000288 & 0.000263 & 0.000248 & 0.0003 & 15.27 & 1.164 & -0.229 & 1.166 & 1.098 & 1.060 \\
\hline 95 & $\mathrm{KJ} 3873 \mathrm{C}$ & 074 & 24 & 173 & 18 & 296 & 59 & 0.000368 & 0.000310 & 0.000289 & 0.0003 & 24.22 & 1.270 & -0.416 & 1.279 & 1.184 & 1.072 \\
\hline 26 & KJ3881A & 077 & 51 & 218 & 32 & 321 & 20 & 0.001721 & 0.001392 & 0.001165 & 0.0014 & 38.95 & 1.477 & -0.086 & 1.479 & 1.236 & 1.195 \\
\hline 7 & KJ3881B & 082 & 54 & 217 & 27 & 310 & 22 & 0.001487 & 0.001219 & 0.000995 & 0.0012 & 39.87 & 1.494 & 0.009 & 1.490 & 1.220 & 1.22 \\
\hline 98 & KJ3881C & 095 & 54 & 217 & 22 & 319 & 27 & 0.001127 & 0.000947 & 0.000769 & 0.0009 & 37.82 & 1.466 & 0.090 & 1.469 & 1.190 & 1.232 \\
\hline 9 & $\mathrm{KJ} 3882 \mathrm{~A}$ & 213 & 29 & 022 & 60 & 120 & 05 & 0.001620 & 0.001256 & 0.001015 & 0.0013 & 46.68 & 1.597 & -0.090 & 1.601 & 1.290 & 1.237 \\
\hline 00 & $K J 38828$ & 212 & 23 & 021 & 67 & 120 & 04 & 0.001656 & 0.001258 & 0.001040 & 0.0013 & 46.70 & 1.592 & -0.184 & 1.599 & 1.317 & 1.20 \\
\hline 01 & $\mathrm{KJ} 3882 \mathrm{C}$ & 216 & 28 & 021 & 61 & 123 & 06 & 0.002385 & 0.001840 & 0.001470 & 0.0019 & 48.20 & 1.622 & -0.073 & 1.627 & 1.296 & 1.25 \\
\hline 102 & KJ3883A & 101 & 66 & 229 & 15 & 323 & 18 & 0.000503 & 0.000494 & 0.000382 & 0.0005 & 28.42 & 1.318 & 0.869 & 1.363 & 1.018 & 1.29 \\
\hline 103 & KJ38838 & 115 & 64 & 230 & 11 & 325 & 23 & 0.000379 & 0.000354 & 0.000308 & 0.0003 & 20.42 & 1.230 & 0.342 & 1.235 & 1.070 & 1.14 \\
\hline 104 & KJ3883C & 052 & 02 & 146 & 59 & 321 & 31 & 0.000249 & 0.000235 & 0.000184 & 0.0002 & 29.35 & 1.355 & 0.597 & 1.380 & 1.063 & 1.27 \\
\hline 105 & $\mathrm{KJ} 3884 \mathrm{~A}$ & 085 & 49 & 347 & 07 & 251 & 40 & 0.000418 & 0.000404 & 0.000384 & 0.0004 & 8.30 & 1.087 & 0.208 & 1.087 & 1.034 & 1.05 \\
\hline 106 & KJ3891A & 077 & 69 & 190 & 09 & 283 & 19 & 0.000356 & 0.000349 & 0.000325 & 0.0003 & 8.99 & 1.095 & 0.560 & 1.100 & 1.020 & 1.07 \\
\hline 107 & KJ3891B & 087 & 68 & 194 & 07 & 287 & 20 & 0.000365 & 0.000357 & 0.000328 & 0.0003 & 10.65 & 1.114 & 0.584 & 1.120 & 1.023 & 1.085 \\
\hline 08 & $K J 3892 \mathrm{~A}$ & 028 & 14 & 135 & 49 & 287 & 38 & 0.000395 & 0.000392 & 0.000378 & 0.0004 & 4.34 & 1.045 & 0.601 & 1.047 & 1.009 & 1.03 \\
\hline 109 & KJ3892B & 028 & 13 & 135 & 53 & 289 & 34 & 0.000445 & 0.000442 & 0.000428 & 0.0004 & 4.00 & 1.041 & 0.621 & 1.044 & 1.008 & 1.03 \\
\hline 110 & $K J 3893 \mathrm{~A}$ & 081 & 60 & 194 & 13 & 290 & 27 & 0.000320 & 0.000313 & 0.000277 & 0.0003 & 14.18 & 1.155 & 0.696 & 1.168 & 1.022 & 1.13 \\
\hline 111 & KJ3893B & 137 & 58 & 026 & 12 & 289 & 29 & 0.000342 & 0.000333 & 0.000297 & 0.0003 & 13.83 & 1.151 & 0.612 & 1.161 & 1.028 & 1.12 \\
\hline 112 & KJ3893C & 143 & 50 & 041 & 10 & 304 & 38 & 0.000319 & 0.000307 & 0.000275 & 0.0003 & 14.59 & 1.159 & 0.451 & 1.165 & 1.041 & 1.11 \\
\hline 113 & KJ3894A & 027 & 00 & 117 & 64 & 296 & 26 & 0.001179 & 0.001093 & 0.001001 & 0.0011 & 16.31 & 1.178 & 0.068 & 1.178 & 1.079 & 1.09 \\
\hline 114 & KJ3894B & 027 & 04 & 125 & 63 & 295 & 27 & 0.000855 & 0.000804 & 0.000736 & 0.0008 & 14.88 & 1.161 & 0.181 & 1.162 & 1.063 & 1.09 \\
\hline 115 & KJ3894C & 033 & 19 & 152 & 54 & 292 & 29 & 0.000631 & 0.000609 & 0.000386 & 0.0005 & 45.20 & 1.635 & 0.855 & 1.735 & 1.036 & 1.57 \\
\hline 116 & KJ3901A & 025 & 27 & 145 & 44 & 275 & 33 & 0.143577 & 0.129779 & 0.101944 & 0.1251 & 33.28 & 1.408 & 0.410 & 1.423 & 1.106 & 1.27 \\
\hline 117 & KJ3901B & 026 & 39 & 154 & 37 & 270 & 29 & 0.094140 & 0.084936 & 0.068335 & 0.0825 & 31.29 & 1.378 & 0.358 & 1.388 & 1.108 & 1.24 \\
\hline 18 & KJ3901C & 022 & 52 & 162 & 31 & 265 & 20 & 0.119181 & 0.106874 & 0.084745 & 0.1036 & 33.24 & 1.406 & 0.361 & 1.418 & 1.115 & 1.26 \\
\hline 19 & $\mathrm{~K} J 3902 \mathrm{~A}$ & 219 & 15 & 108 & 54 & 310 & 32 & 0.056304 & 0.051876 & 0.037799 & 0.0487 & 38.03 & 1.490 & 0.589 & 1.526 & 1.085 & 1.37 \\
\hline 20 & $K J 3902 B$ & 210 & 17 & 099 & 49 & 313 & 36 & 0.021481 & 0.018519 & 0.014090 & 0.0180 & 40.99 & 1.525 & 0.296 & 1.536 & 1.160 & 1.31 \\
\hline
\end{tabular}

Tab. 5.1. Dados de ASM

Coordenadas geográficas e escalares de $K 1, K 2$ e $K 3$, valores de susceptibilidade e parâmetros de anisotropia magnética. 
Amostra

\begin{tabular}{|c|c|c|c|c|c|}
\hline Amostra & $\mathrm{A} z \mathrm{~K} 1$ & $M \mathrm{~K} 1$ & $\mathrm{AzK} 2$ & M K2 & $A z k 3$ \\
\hline $1 \mathrm{KJ} 3903 \mathrm{~A}$ & 047 & 56 & 160 & 15 & 259 \\
\hline 2 KJ3903B & 033 & 59 & 165 & 22 & 264 \\
\hline $3 \mathrm{KJ} 3911 \mathrm{~A}$ & 038 & 06 & 186 & 83 & 307 \\
\hline $4 \mathrm{KJ} 3911 \mathrm{~B}$ & 038 & 05 & 159 & 80 & 308 \\
\hline $25 \mathrm{KJ} 3911 \mathrm{C}$ & 038 & 06 & 181 & 82 & 308 \\
\hline $126 \mathrm{KJ} 3912 \mathrm{~A}$ & 038 & 11 & 192 & 78 & 307 \\
\hline $27 \quad K J 39128$ & 038 & 07 & 193 & 82 & 308 \\
\hline $8 \mathrm{KJ} 3912 \mathrm{C}$ & 040 & 06 & 235 & 84 & 130 \\
\hline $9 \mathrm{KJ} 3913 \mathrm{~A}$ & 034 & 10 & 202 & 80 & 303 \\
\hline $0 \mathrm{KJ} 3913 \mathrm{~B}$ & 032 & 02 & 131 & 78 & 302 \\
\hline $1 \mathrm{KJ} 3913 \mathrm{C}$ & 031 & 11 & 195 & 78 & 301 \\
\hline $2 \mathrm{KJ} 3914 \mathrm{~B}$ & 032 & 11 & 186 & 77 & 301 \\
\hline $3 \mathrm{KJ} 3914 \mathrm{C}$ & 031 & 17 & 203 & 73 & 300 \\
\hline $4 \mathrm{KJ} 3941 \mathrm{A1}$ & 224 & 17 & 107 & 57 & 323 \\
\hline $5 \mathrm{KJ} 3941 \mathrm{~A} 2$ & 002 & 34 & 128 & 41 & 248 \\
\hline $6 \mathrm{KJ} 3941 \mathrm{B1}$ & 221 & 07 & 120 & 58 & 315 \\
\hline $7 \mathrm{KJ} 3941 \mathrm{~B} 2$ & 224 & 11 & 116 & 57 & 320 \\
\hline $8 \mathrm{KJ} 3941 \mathrm{C1}$ & 229 & 01 & 138 & 58 & 320 \\
\hline $9 \mathrm{KJ} 3941 \mathrm{C} 2$ & 233 & 00 & 142 & 61 & 323 \\
\hline $\mathrm{KJ} 3941 \mathrm{C} 3$ & 233 & 02 & 139 & 60 & 324 \\
\hline KJ3941D1 & 233 & 10 & 131 & 51 & 331 \\
\hline KJ3941E1 & 219 & 07 & 118 & 55 & 314 \\
\hline KJ3941E2 & 221 & 03 & 127 & 56 & 312 \\
\hline KJ3941E3 & 225 & 02 & 131 & 57 & 316 \\
\hline $\mathrm{KJ} 3941 \mathrm{F1}$ & 221 & 06 & 120 & 60 & 314 \\
\hline $\mathrm{KJ} 3941 \mathrm{F2}$ & 225 & 07 & 012 & 63 & 318 \\
\hline $7 \mathrm{KJ} 3941 \mathrm{F3}$ & 056 & 12 & 162 & 53 & 318 \\
\hline KJ3971A & 223 & 04 & 125 & 62 & 315 \\
\hline KJ3971B & 224 & 04 & 127 & 60 & 317 \\
\hline KJ397A1C & 226 & 03 & 130 & 62 & 318 \\
\hline KJ3972A & 227 & 03 & 130 & 65 & 318 \\
\hline KJ3973A & 224 & 04 & 125 & 63 & 316 \\
\hline KJ39738 & 222 & 06 & 119 & 66 & 315 \\
\hline $\mathrm{KJ} 3973 \mathrm{C}$ & 225 & 09 & 120 & 57 & 320 \\
\hline KJ3974A & 223 & 03 & 127 & 61 & 315 \\
\hline KJ3974B & 043 & 00 & 133 & 65 & 313 \\
\hline KJ3974C & 225 & 03 & 129 & 60 & 317 \\
\hline $\mathrm{KJ} 3975 \mathrm{~A}$ & 222 & 05 & 121 & 64 & 315 \\
\hline KJ3975B & 222 & 04 & 124 & 62 & 314 \\
\hline KJ3976A & 209 & 03 & 108 & 75 & 300 \\
\hline
\end{tabular}

$\begin{array}{ccccc}M K 3 & K 1 & K 2 & K 3 & K m \\ 30 & 0.122876 & 0.105268 & 0.088346 & 0.1055 \\ 21 & 0.129603 & 0.112614 & 0.091983 & 0.1114 \\ 04 & 0.006122 & 0.005206 & 0.004107 & 0.0051 \\ 09 & 0.004972 & 0.004273 & 0.003376 & 0.0042 \\ 05 & 0.003824 & 0.003195 & 0.002566 & 0.0032 \\ 05 & 0.028297 & 0.023180 & 0.016143 & 0.0225 \\ 03 & 0.033216 & 0.027560 & 0.019712 & 0.0268 \\ 02 & 0.030408 & 0.025277 & 0.017995 & 0.0246 \\ 02 & 0.004061 & 0.003472 & 0.002669 & 0.0034 \\ 12 & 0.000535 & 0.000493 & 0.000413 & 0.0005 \\ 03 & 0.008264 & 0.007134 & 0.005170 & 0.0069 \\ 05 & 0.017439 & 0.015024 & 0.010647 & 0.0144 \\ 02 & 0.007285 & 0.006229 & 0.004881 & 0.0061 \\ 28 & 0.014052 & 0.011053 & 0.006396 & 0.0105 \\ 30 & 0.012689 & 0.010265 & 0.005644 & 0.0095 \\ 31 & 0.007686 & 0.006456 & 0.003849 & 0.0060 \\ 30 & 0.003324 & 0.002885 & 0.001997 & 0.0027 \\ 32 & 0.002515 & 0.002291 & 0.001881 & 0.0022 \\ 29 & 0.002455 & 0.002288 & 0.001788 & 0.0022 \\ 30 & 0.002481 & 0.002272 & 0.001814 & 0.0022 \\ 37 & 0.000896 & 0.000858 & 0.000738 & 0.0008 \\ 34 & 0.004309 & 0.003873 & 0.003002 & 0.0037 \\ 34 & 0.004449 & 0.004005 & 0.003132 & 0.0039 \\ 33 & 0.004658 & 0.004224 & 0.003304 & 0.0041 \\ 29 & 0.001581 & 0.001475 & 0.001207 & 0.0014 \\ 26 & 0.002023 & 0.001843 & 0.001454 & 0.0018 \\ 35 & 0.001376 & 0.001292 & 0.001154 & 0.0013 \\ 27 & 0.023629 & 0.020523 & 0.014258 & 0.0195 \\ 60 & 0.024510 & 0.020906 & 0.014584 & 0.0200 \\ 28 & 0.026162 & 0.022096 & 0.015042 & 0.0211 \\ 25 & 0.012122 & 0.010608 & 0.008532 & 0.0104 \\ 26 & 0.012420 & 0.010858 & 0.008162 & 0.0105 \\ 23 & 0.011542 & 0.009960 & 0.007667 & 0.0097 \\ 32 & 0.011359 & 0.009827 & 0.007680 & 0.0096 \\ 29 & 0.028706 & 0.025005 & 0.018527 & 0.0241 \\ 25 & 0.018935 & 0.016304 & 0.012163 & 0.0158 \\ 30 & 0.016979 & 0.014783 & 0.011078 & 0.0143 \\ 25 & 0.015390 & 0.013278 & 0.009852 & 0.0128 \\ 18 & 0.016383 & 0.014138 & 0.010219 & 0.0136 \\ 15 & 0.012553 & 0.010897 & 0.008619 & 0.0107\end{array}$

$H$
32.73
33.77
39.16
37.94
39.40
53.92
50.33
50.54
40.92
25.42
45.12
47.27
39.21
72.92
73.90
63.98
48.53
28.46
30.62
30.45
19.02
35.06
34.09
33.34
26.32
32.10
17.39
48.13
49.63
52.70
34.45
40.63
39.86
38.23
42.27
42.86
41.32
43.13
45.39
36.80

1.391

1.409

1.491

1.473

1.491

1.753

1.685

1.690

1.521

1.296

1.598

1.638

1.493

2.197

2.248

1.997

1.665

1.337

1.373

1.367

1214

1.435

1.420

1410

1.310

1.392

1.192

1.657
1.681

1.739

1.421

1.522

1.506

1.479

1.549

1.557

1.533

1.562

1.603

1.456

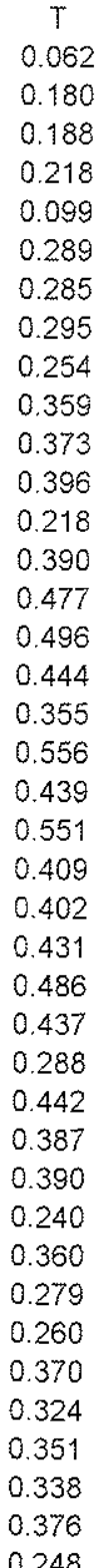

1.392 1.167

1.413

1.496

1.151

$\begin{array}{ll}1.221 & 1.436\end{array}$

1.398

$\begin{array}{lll}1.708 & 1.203 & 1.405 \\ 1.530 & 1.170 & 1.301\end{array}$

$1.303 \quad 1.086 \quad 1192$

$\begin{array}{lll}1.619 & 1.158 & 1.380\end{array}$

$\begin{array}{lll}1.663 & 1.161 & 1.411\end{array}$

$1.499 \quad 1.170 \quad 1276$

$2.263 \quad 1.271 \quad 1.728$

$\begin{array}{lll}2.342 & 1.236 & 1.819\end{array}$

$\begin{array}{lll}2.067 & 1.190 & 1.677\end{array}$

$1.697 \quad 1.152 \quad 1.445$

$\begin{array}{lll}1.346 & 1.098 & 1.218\end{array}$

$\begin{array}{lll}1.396 & 1.073 & 1.280\end{array}$

$\begin{array}{lll}1.382 & 1.092 & 1.253\end{array}$

$\begin{array}{lll}1.226 & 1.045 & 1.162\end{array}$

$\begin{array}{lll}1.451 & 1.113 & 1.290\end{array}$

$1.435 \quad 1.111 \quad 1.279$

$\begin{array}{lll}1.426 & 1.103 & 1.279\end{array}$

$\begin{array}{lll}1.324 & 1.072 & 1.222\end{array}$

$\begin{array}{lll}1.407 & 1.098 \quad 1.268\end{array}$

$\begin{array}{lll}1.195 & 1.064 & 1.120\end{array}$

$\begin{array}{lll}1.689 & 1.151 & 1.439\end{array}$

$\begin{array}{lll}1.707 & 1.172 & 1.433\end{array}$

$1.770 \quad 1.184 \quad 1.469$

$1.427 \quad 1.143 \quad 1.243$

$1.538 \quad 1.144 \quad 1.330$

$\begin{array}{lll}1.516 & 1.159 & 1.299\end{array}$

$\begin{array}{lll}1.487 & 1.156 & 1.280\end{array}$

$\begin{array}{lll}1.567 & 1.148 & 1.350\end{array}$

$\begin{array}{lll}1.572 & 1.161 & 1.340\end{array}$

$\begin{array}{lll}1.549 & 1.149 & 1.334\end{array}$

$\begin{array}{lll}1.578 & 1.159 & 1.348\end{array}$

$1.624 \quad 1.159 \quad 1.384$

$1.464 \quad 1.152 \quad 1.264$

Tab. 5.1. Dados de ASM. 


$\begin{array}{lllllll}161 & \text { KJ3976B } & 211 & 02 & 116 & 72 & 301 \\ 162 & \text { KJ3981A } & 224 & 02 & 131 & 55 & 316 \\ 163 & \text { KJ3981A } & 218 & 06 & 120 & 52 & 313 \\ 164 & \text { KJ3982 } & 043 & 03 & 136 & 46 & 310 \\ 165 & \text { KJ3983 } & 236 & 14 & 131 & 45 & 339 \\ 166 & \text { KJ3984 } & 226 & 04 & 132 & 52 & 319 \\ 167 & \text { KJ3985 } & 229 & 07 & 130 & 52 & 324 \\ 168 & \text { KJ3986A } & 224 & 07 & 124 & 55 & 318 \\ 169 & \text { KJ39826B } & 224 & 08 & 122 & 56 & 319 \\ 170 & \text { KJ3987 } & 224 & 08 & 120 & 60 & 319 \\ 171 & \text { KJ3988AX } & 222 & 05 & 125 & 57 & 315 \\ 172 & \text { KJ3988BY } & 220 & 02 & 126 & 64 & 311 \\ 173 & \text { KJ3988CZ } & 220 & 06 & 120 & 61 & 313 \\ 174 & \text { KJ3989A } & 228 & 07 & 127 & 58 & 322 \\ 175 & \text { KJ3989B } & 226 & 08 & 125 & 54 & 321 \\ 176 & \text { KJ39810 } & 050 & 04 & 145 & 54 & 317 \\ 177 & \text { KJ39811 } & 044 & 05 & 141 & 52 & 310 \\ 178 & \text { KJ4021A1 } & 221 & 06 & 119 & 62 & 314 \\ 179 & \text { KJ4022B1 } & 219 & 03 & 123 & 62 & 310 \\ 180 & \text { KJ4022B2 } & 213 & 08 & 110 & 60 & 308 \\ 181 & \text { KJ4022B3 } & 215 & 07 & 114 & 58 & 309 \\ 182 & \text { KJ4023C1 } & 215 & 10 & 103 & 66 & 310 \\ 183 & \text { KJ4025E1 } & 221 & 06 & 120 & 62 & 315 \\ 184 & \text { KJ4025E2 } & 222 & 01 & 130 & 62 & 312 \\ 185 & \text { KJ4026F } & 211 & 09 & 102 & 64 & 306 \\ 186 & \text { KJ4026F1 } & 216 & 12 & 105 & 59 & 313 \\ 187 & \text { KJ4081A } & 145 & 54 & 050 & 04 & 318 \\ 188 & \text { KJ4081B } & 186 & 45 & 069 & 24 & 321 \\ 189 & \text { KJ4081C } & 119 & 53 & 222 & 09 & 318 \\ 190 & \text { KJ4082A } & 175 & 48 & 060 & 21 & 314 \\ 191 & \text { KJ4082C } & 161 & 51 & 057 & 11 & 318 \\ 192 & \text { KJ4083A } & 162 & 50 & 056 & 13 & 316 \\ 193 & \text { KJ4083B } & 140 & 52 & 049 & 01 & 318 \\ 194 & \text { KJ4083C } & 150 & 56 & 051 & 06 & 317 \\ 195 & \text { KJ4084A } & 144 & 49 & 049 & 05 & 315 \\ 196 & \text { KJ4084B } & 122 & 47 & 219 & 06 & 315 \\ 197 & \text { KJ4084C } & 150 & 53 & 049 & 09 & 312 \\ 198 & \text { KJ4121A } & 249 & 00 & 159 & 09 & 341 \\ 199 & \text { KJ44122A } & 092 & 59 & 221 & 20 & 319 \\ 200 & \text { KJ4122B } & 086 & 55 & 227 & 29 & 327\end{array}$

\begin{tabular}{|c|c|c|c|c|c|c|c|c|c|}
\hline K1 & $K_{2}$ & K3 & $\mathrm{Km}$ & $H$ & P & $T$ & $p^{\prime}$ & L & $F$ \\
\hline 0.013110 & 0.011468 & 0.009052 & 0.0112 & 36.20 & 1.448 & 0.277 & 1.457 & 1.143 & 1.267 \\
\hline 0.026887 & 0.019159 & 0.010142 & 0.0187 & 89.40 & 2.651 & 0.305 & 2.739 & 1.403 & 1.889 \\
\hline 0.036449 & 0.027194 & 0.015887 & 0.0265 & 77.56 & 2.294 & 0.295 & 2.348 & 1.340 & 1.712 \\
\hline 0.070996 & 0.054108 & 0.040730 & 0.0553 & 54.75 & 1.743 & 0.022 & 1.749 & 1.312 & 1.328 \\
\hline 0.112003 & 0.096306 & 0.062950 & 0.0904 & 54.25 & 1.779 & 0.476 & 1.825 & 1.163 & 1.530 \\
\hline 0.030766 & 0.023042 & 0.016904 & 0.0236 & 58.81 & 1.820 & 0.034 & 1.828 & 1.335 & 1.363 \\
\hline 0.051984 & 0.035578 & 0.024248 & 0.0373 & 74.42 & 2.144 & 0.005 & 2.163 & 1.461 & 1.467 \\
\hline 0.030644 & 0.019907 & 0.011099 & 0.0206 & 95.11 & 2.761 & 0.150 & 2.827 & 1.539 & 1.794 \\
\hline 0.019848 & 0.013977 & 0.008984 & 0.0143 & 76.13 & 2.209 & 0.115 & 2.235 & 1.420 & 1.556 \\
\hline 0.039406 & 0.024188 & 0.012634 & 0.0254 & 105.36 & 3.119 & 0.142 & 3.219 & 1.629 & 1.915 \\
\hline 0.006021 & 0.004617 & 0.002915 & 0.0045 & 68.74 & 2.065 & 0.268 & 2.099 & 1.304 & 1.584 \\
\hline 0.009127 & 0.006864 & 0.004694 & 0.0069 & 64.29 & 1.944 & 0.143 & 1.960 & 1.330 & 1.462 \\
\hline 0.008312 & 0.005754 & 0.003727 & 0.0059 & 77.30 & 2.230 & 0.083 & 2.255 & 1.444 & 1.544 \\
\hline 0.003871 & 0.003391 & 0.002640 & 0.0033 & 37.28 & 1.466 & 0.308 & 1.477 & 1.141 & 1.284 \\
\hline 0.001858 & 0.001626 & 0.001283 & 0.0016 & 36.20 & 1.448 & 0.277 & 1.457 & 1.143 & 1.267 \\
\hline 0.003732 & 0.003136 & 0.002366 & 0.0031 & 44.39 & 1.577 & 0.235 & 1.587 & 1.190 & 1.325 \\
\hline 0.001746 & 0.001393 & 0.001102 & 0.0014 & 45.54 & 1.584 & 0.017 & 1.587 & 1.254 & 1.263 \\
\hline 0.014669 & 0.011365 & 0.002700 & 0.0096 & 124.96 & 5.433 & 0.698 & 6.718 & 1.291 & 4.209 \\
\hline 0.075106 & 0.054569 & 0.026530 & 0.0521 & 93.29 & 2.831 & 0.386 & 2.966 & 1.376 & 2.057 \\
\hline 0.037639 & 0.028390 & 0.013951 & 0.0267 & 88.85 & 2.698 & 0.432 & 2.833 & 1.326 & 2.035 \\
\hline 0.052488 & 0.040043 & 0.017568 & 0.0367 & 95.15 & 2.988 & 0.505 & 3.205 & 1.311 & 2.279 \\
\hline 0.054041 & 0.043247 & 0.009512 & 0.0356 & 125.08 & 5.681 & 0.743 & 7.219 & 1.250 & 4.546 \\
\hline 0.051935 & 0.040662 & 0.020773 & 0.0378 & 82.46 & 2.500 & 0.466 & 2.622 & 1.277 & 1.957 \\
\hline 0.048954 & 0.039111 & 0.020265 & 0.0361 & 79.45 & 2.416 & 0.491 & 2.535 & 1.252 & 1.930 \\
\hline 0.028796 & 0.021302 & 0.011462 & 0.0205 & 84.47 & 2.512 & 0.346 & 2.597 & 1.352 & 1.858 \\
\hline 0.023910 & 0.020134 & 0.009896 & 0.0180 & 77.94 & 2.416 & 0.610 & 2.584 & 1.188 & 2.035 \\
\hline 0.004920 & 0.004618 & 0.002698 & 0.0041 & 54.48 & 1.824 & 0.789 & 1.945 & 1.065 & 1.712 \\
\hline 0.005238 & 0.004855 & 0.002936 & 0.0043 & 53.00 & 1.784 & 0.737 & 1.884 & 1.079 & 1.653 \\
\hline 0.003889 & 0.003722 & 0.002052 & 0.0032 & 57.02 & 1.895 & 0.863 & 2.056 & 1.045 & 1.814 \\
\hline 0.003015 & 0.002836 & 0.001670 & 0.0025 & 53.64 & 1.805 & 0.794 & 1.925 & 1.063 & 1.699 \\
\hline 0.003363 & 0.003201 & 0.001875 & 0.0028 & 52.89 & 1.794 & 0.832 & 1.921 & 1.050 & 1.708 \\
\hline 0.002997 & 0.002884 & 0.001694 & 0.0025 & 51.59 & 1.769 & 0.866 & 1.901 & 1.039 & 1.703 \\
\hline 0.003723 & 0.003555 & 0.002019 & 0.0031 & 55.00 & 1.844 & 0.848 & 1.988 & 1.048 & 1.761 \\
\hline 0.003212 & 0.003037 & 0.001817 & 0.0027 & 51.87 & 1.767 & 0.803 & 1.882 & 1.058 & 1.671 \\
\hline 0.004885 & 0.004576 & 0.002596 & 0.0040 & 56.96 & 1.882 & 0.793 & 2.017 & 1.068 & 1.763 \\
\hline 0.004133 & 0.003864 & 0.002128 & 0.0034 & 59.42 & 1.943 & 0.798 & 2.092 & 1.070 & 1.816 \\
\hline $0.0027 \uparrow 5$ & 0.002588 & 0.001697 & 0.0023 & 43.65 & 1.600 & 0.796 & 1.682 & 1.049 & 1.525 \\
\hline 0.015237 & 0.012295 & 0.005239 & 0.0109 & 91.55 & 2.908 & 0.598 & 3.167 & 1.239 & 2.347 \\
\hline 0.001055 & 0.000837 & 0.000759 & 0.0009 & 33.48 & 1.390 & -0.409 & 1.403 & 1.261 & 1.102 \\
\hline 0.000472 & 0.000391 & 0.000349 & 0.0004 & 30.44 & 1.352 & -0.252 & 1.357 & 1.208 & 1.120 \\
\hline
\end{tabular}

Tab. 5.1. Dados de ASM.

Coordenadas geográficas e escalares de $\mathrm{K} 1, \mathrm{~K} 2$ e $\mathrm{K} 3$, valores de susceptibilidade e parâmetros de anisotropia magnética. 
Amostra AzK1 MK1 AzK2 MK2 AzK3

$\begin{array}{lllllll}201 & \text { KJ4123A } & 057 & 47 & 218 & 41 & 316 \\ 202 & \text { KJ4124A } & 063 & 51 & 220 & 37 & 319 \\ 203 & \text { KJ41214B } & 053 & 44 & 214 & 44 & 313 \\ 204 & \text { KJ41215A } & 069 & 54 & 201 & 26 & 303 \\ 205 & \text { KJ4125B } & 088 & 65 & 209 & 14 & 304 \\ 206 & \text { KJ4125C } & 096 & 75 & 206 & 05 & 298 \\ 207 & \text { KJ4126A } & 060 & 49 & 210 & 37 & 312 \\ 208 & \text { KJ4126B } & 059 & 46 & 199 & 36 & 305 \\ 209 & \text { KJ4127A } & 059 & 41 & 237 & 49 & 328 \\ 210 & \text { KJ4127B } & 059 & 52 & 208 & 34 & 309 \\ 211 & \text { KJ4127C } & 052 & 35 & 194 & 48 & 308 \\ 212 & \text { KJ413M1A } & 185 & 42 & 051 & 38 & 299 \\ 213 & \text { KJ413M1B } & 165 & 25 & 051 & 16 & 311 \\ 214 & \text { KJ413M1C } & 195 & 38 & 064 & 40 & 309 \\ 215 & \text { KJ4132 } & 221 & 12 & 115 & 51 & 320 \\ 216 & \text { KJ4133A } & 150 & 29 & 038 & 34 & 270 \\ 217 & \text { KJ4133B } & 211 & 28 & 094 & 40 & 325 \\ 218 & \text { KJ4133C } & 208 & 23 & 097 & 41 & 319 \\ 219 & \text { KJ4153A } & 058 & 25 & 192 & 56 & 317 \\ 220 & \text { KJ4154B } & 051 & 27 & 191 & 56 & 311 \\ 221 & \text { KJ4154A } & 058 & 25 & 189 & 54 & 316 \\ 222 & \text { KJ4155A } & 058 & 31 & 209 & 55 & 320 \\ 223 & \text { KJ4152A } & 056 & 26 & 206 & 58 & 327 \\ 224 & \text { KJ4155B } & 056 & 31 & 204 & 55 & 317 \\ 225 & \text { KJ4153B } & 058 & 23 & 183 & 53 & 315 \\ 226 & \text { KJ4151A } & 293 & 45 & 091 & 43 & 192 \\ 227 & \text { KJ4164A } & 110 & 57 & 210 & 06 & 304 \\ 228 & \text { KJ4164B } & 359 & 26 & 113 & 39 & 245 \\ 229 & \text { KJ4165A } & 181 & 46 & 055 & 29 & 307 \\ 230 & \text { KJ4165B } & 166 & 58 & 052 & 14 & 314 \\ 231 & \text { KJ4166A } & 200 & 37 & 089 & 26 & 333 \\ 232 & \text { KJ4161A } & 183 & 31 & 061 & 41 & 296 \\ 233 & \text { KJ4162A } & 183 & 31 & 066 & 36 & 301 \\ 234 & \text { KJ4167A } & 203 & 09 & 095 & 64 & 297 \\ 235 & \text { KJ4167C } & 034 & 23 & 163 & 57 & 294 \\ 236 & \text { KJ4168A } & 126 & 52 & 287 & 37 & 024 \\ 237 & \text { KJ4168B } & 208 & 79 & 113 & 01 & 022 \\ 238 & \text { KJ4168C } & 199 & 75 & 289 & 00 & 019 \\ 239 & \text { KJ44173B } & 136 & 50 & 038 & 07 & 302 \\ 240 & \text { KJ4101B } & 087 & 40 & 183 & 08 & 283\end{array}$

$240 \mathrm{KJ4181B} \quad 087$

10
10
23
21
14
15
21
15
20
30
27
36
42
37
40
12
24
14
18
15
27
11
32
40
30
28
42
33
38
24
10
11
39
49

$\begin{array}{lll}K 2 & K 3\end{array}$ $\begin{array}{lll}0.000271 & 0.000264 & 0.000232\end{array}$ $\begin{array}{llll}0.000530 & 0.000512 & 0.000468\end{array}$ $\begin{array}{lllll}0.000294 & 0.000289 & 0.000262 & 0.0003\end{array}$ $\begin{array}{lllll}0.000367 & 0.000364 & 0.000321 & 0.0004\end{array}$ $\begin{array}{lllll}0.000402 & 0.000392 & 0.000352 & 0.0004\end{array}$ $\begin{array}{lllll}0.000462 & 0.000442 & 0.000394 & 0.0004\end{array}$ $\begin{array}{lllll}0.000563 & 0.000531 & 0.000482 & 0.0005\end{array}$ $\begin{array}{llll}0.000362 & 0.000355 & 0.000350 & 0.0004\end{array}$ $\begin{array}{lllll}0.000298 & 0.000291 & 0.000278 & 0.0003\end{array}$ $\begin{array}{lllll}0.000367 & 0.000358 & 0.000343 & 0.0004\end{array}$ $\begin{array}{lllll}0.000775 & 0.000746 & 0.000678 & 0.0007\end{array}$ $\begin{array}{llll}0.000645 & 0.000617 & 0.000554 & 0.0006\end{array}$ $\begin{array}{lllll}0.000368 & 0.000319 & 0.000284 & 0.0003\end{array}$ $\begin{array}{lllll}0.021116 & 0.016882 & 0.012673 & 0.0169\end{array}$ $\begin{array}{lllll}0.022267 & 0.017344 & 0.012049 & 0.0172\end{array}$ $\begin{array}{lllll}0.022249 & 0.017162 & 0.012701 & 0.0174\end{array}$ $\begin{array}{lllll}0.024847 & 0.019097 & 0.014139 & 0.0194\end{array}$ $\begin{array}{lllll}0.002793 & 0.002356 & 0.001986 & 0.0024\end{array}$ $\begin{array}{llll}0.001618 & 0.001525 & 0.001387 & 0.0015\end{array}$ $\begin{array}{lllll}0.001799 & 0.001454 & 0.001337 & 0.0015\end{array}$ $\begin{array}{lllll}0.001733 & 0.001629 & 0.001453 & 0.0016\end{array}$ $\begin{array}{llll}0.001027 & 0.000920 & 0.000782 & 0.0009\end{array}$ $\begin{array}{lllll}0.002013 & 0.001892 & 0.001681 & 0.0019\end{array}$ $\begin{array}{lllll}0.001700 & 0.001615 & 0.001434 & 0.0016\end{array}$ $\begin{array}{llll}0.001305 & 0.001216 & 0.001133 & 0.0012\end{array}$ $\begin{array}{llll}0.004245 & 0.003725 & 0.003145 & 0.0037\end{array}$ $\begin{array}{lllll}0.001040 & 0.000999 & 0.000845 & 0.0010\end{array}$ $\begin{array}{llll}0.001013 & 0.000972 & 0.000763 & 0.0009\end{array}$ $\begin{array}{lllll}0.000982 & 0.000942 & 0.000746 & 0.0009\end{array}$ $\begin{array}{lllll}0.000558 & 0.000552 & 0.000495 & 0.0005\end{array}$ $\begin{array}{lllll}0.000898 & 0.000858 & 0.000673 & 0.0008\end{array}$ $\begin{array}{lllll}0.000909 & 0.000891 & 0.000765 & 0.0009\end{array}$ $\begin{array}{lllll}0.001747 & 0.001577 & 0.001377 & 0.0016\end{array}$ $\begin{array}{lllll}0.001329 & 0.001240 & 0.001053 & 0.0012\end{array}$ $\begin{array}{lllll}0.008359 & 0.008270 & 0.004923 & 0.0072\end{array}$ $\begin{array}{lllll}0.007328 & 0.006835 & 0.004180 & 0.0061\end{array}$ $\begin{array}{lllll}0.004927 & 0.004755 & 0.003014 & 0.0042\end{array}$ $\begin{array}{lllll}0.115739 & 0.099279 & 0.026211 & 0.0804\end{array}$ $\begin{array}{llll}0.001762 & 0.001618 & 0.001399 & 0.0016\end{array}$

$\begin{array}{cc}H & P \\ 15.25 & 1.168 \\ 12.32 & 1.133 \\ 10.16 & 1.108 \\ 11.08 & 1.119 \\ 13.35 & 1.146 \\ 13.05 & 1.142 \\ 15.80 & 1.174 \\ 15.48 & 1.169 \\ 3.51 & 1.036 \\ 6.80 & 1.071 \\ 6.83 & 1.071 \\ 13.12 & 1.142 \\ 14.98 & 1.164 \\ 25.99 & 1.296 \\ 49.99 & 1.666 \\ 59.34 & 1.848 \\ 54.97 & 1.752 \\ 55.31 & 1.757 \\ 33.95 & 1.407 \\ 15.30 & 1.167 \\ 30.15 & 1.345 \\ 17.41 & 1.192 \\ 26.90 & 1.313 \\ 17.82 & 1.197 \\ 16.76 & 1.185 \\ 14.15 & 1.152 \\ 29.68 & 1.350 \\ 20.07 & 1.231 \\ 27.26 & 1.327 \\ 26.49 & 1.316 \\ 11.80 & 1.128 \\ 27.74 & 1.334 \\ 16.82 & 1.188 \\ 23.61 & 1.269 \\ 22.84 & 1.262 \\ 47.82 & 1.698 \\ 51.49 & 1.753 \\ 45.20 & 1.635 \\ 102.47 & 4.416 \\ 22.80 & 1.260\end{array}$
T

0.668 0.449

0.573

0.697

0.861

0.610

0.443

0.260

$-0.228$

0.307

0.217

0.433

0.404

$-0.108$

0.123

0.186

0.074

0.066

0.002

0.230

$-0.436$

0.299

0.189

0.310

0.401

0.004
0.128

0.128

0.608

0.708
0.701

0.822

0.822

0.687
0.767

0.144

0.404

0.960

0.752

0.855

0.793

0.264

Tab. 5.1. Dados de ASM. 


\begin{tabular}{|c|c|c|c|c|c|c|c|c|c|c|c|c|c|c|c|c|c|}
\hline & Amostra & $A z K 1$ & M K1 & $\mathrm{Az} K 2$ & $M K 2$ & $\mathrm{Az} K 3$ & $\mathrm{M} K 3$ & $\mathrm{~K} 1$ & $\mathrm{~K} 2$ & K3 & $\mathrm{Km}$ & $\mathrm{H}$ & $P$ & $T$ & $P^{*}$ & $L$ & $F$ \\
\hline 241 & KJ41830 & 099 & 46 & 194 & 05 & 289 & 43 & 0.003023 & 0.002726 & 0.002228 & 0.0027 & 29.90 & 1.357 & 0.323 & 1.365 & 1.109 & 1.224 \\
\hline 242 & $\mathrm{KJ} 44183 \mathrm{C}$ & 094 & 47 & 191 & 06 & 286 & 43 & 0.002613 & 0.002379 & 0.001961 & 0.0023 & 28.11 & 1.332 & 0.347 & 1.340 & 1.098 & 1.213 \\
\hline 243 & KJ4182C & 106 & 35 & 201 & 06 & 300 & 54 & 0.001770 & 0.001647 & 0.001416 & 0.0016 & 22.00 & 1.250 & 0.355 & 1.256 & 1.075 & 1.163 \\
\hline 244 & $K J 4183 \mathrm{~A}$ & 086 & 45 & 185 & 09 & 284 & 43 & 0.001854 & 0.001711 & 0.001481 & 0.0017 & 22.18 & 1.252 & 0.287 & 1.256 & 1.083 & 1.156 \\
\hline 245 & KJ4181E & 087 & 41 & 183 & 08 & 282 & 48 & 0.002061 & 0.001913 & 0.001630 & 0.0019 & 23.09 & 1.265 & 0.367 & 1.272 & 1.077 & 1.174 \\
\hline 246 & KJ41838 & 096 & 45 & 191 & 05 & 286 & 45 & 0.002219 & 0.002044 & 0.001725 & 0.0020 & 24.77 & 1.287 & 0.348 & 1.294 & 1.086 & 1.185 \\
\hline 247 & KJ4182A & 111 & 35 & 204 & 04 & 300 & 55 & 2.812938 & 2.498740 & 2.110322 & 2.4740 & 28.40 & 1.333 & 0.176 & 1.336 & 1.126 & 1.184 \\
\hline 248 & KJ419C1 & 044 & 19 & 159 & 52 & 302 & 32 & 0.112855 & 0.107665 & 0.066790 & 0.0958 & 48.10 & 1.690 & 0.820 & 1.793 & 1.048 & 1.612 \\
\hline 249 & $\mathrm{KJ4192B}$ & 070 & 37 & 191 & 34 & 309 & 35 & 0.126484 & 0.120358 & 0.070569 & 0.1058 & 52.85 & 1.792 & 0.830 & 1.919 & 1.051 & 1.706 \\
\hline 250 & KJ4192B & 032 & 24 & 159 & 54 & 289 & 25 & 0.115150 & 0.108236 & 0.067678 & 0.0970 & 48.96 & 1.701 & 0.767 & 1.794 & 1.064 & 1.599 \\
\hline 251 & KJ4192A & 041 & 28 & 165 & 47 & 293 & 30 & 0.109531 & 0.102479 & 0.061681 & 0.0912 & 52.45 & 1.776 & 0.768 & 1.883 & 1.069 & 1.661 \\
\hline 252 & KJ4192C & 033 & 22 & 158 & 55 & 292 & 26 & 0.102503 & 0.097116 & 0.069649 & 0.0898 & 37.69 & 1.472 & 0.721 & 1.522 & 1.055 & 1.394 \\
\hline 253 & KJ4191A & 051 & 33 & 177 & 42 & 299 & 30 & 0.092872 & 0.087347 & 0.052582 & 0.0776 & 51.92 & 1.766 & 0.784 & 1.876 & 1.063 & 1.661 \\
\hline 254 & KJ4192BB & 062 & 37 & 191 & 39 & 308 & 29 & 0.115153 & 0.109381 & 0.059669 & 0.0947 & 57.00 & 1.930 & 0.844 & 2.117 & 1.053 & 1.833 \\
\hline 255 & KJ4192AA & 065 & 36 & 190 & 38 & 309 & 32 & 0.115423 & 0.108843 & 0.064734 & 0.0963 & 52.62 & 1.783 & 0.797 & 1.899 & 1.060 & 1.681 \\
\hline 256 & KJ4191D & 053 & 36 & 182 & 41 & 300 & 29 & 0.071004 & 0.066015 & 0.044841 & 0.0606 & 43.16 & 1.583 & 0.683 & 1.643 & 1.076 & 1.472 \\
\hline 257 & KJ4193B & 116 & 54 & 211 & 04 & 304 & 36 & 0.020618 & 0.018776 & 0.009835 & 0.0184 & 65.71 & 2.096 & 0.747 & 2.260 & 1.098 & 1.909 \\
\hline 258 & KJ4193A & 122 & 60 & 031 & 01 & 301 & 30 & 0.014480 & 0.013395 & 0.007675 & 0.0119 & 57.42 & 1.887 & 0.755 & 2.010 & 1.081 & 1.745 \\
\hline 259 & KJ4193C & 128 & 58 & 034 & 03 & 302 & 32 & 0.013906 & 0.013485 & 0.006989 & 0.0115 & 60.35 & 1.990 & 0.911 & 2.193 & 1.031 & 1.929 \\
\hline 260 & KJ4202B & 067 & 34 & 200 & 45 & 318 & 25 & 0.007311 & 0.007159 & 0.006164 & 0.0069 & 16.68 & 1.186 & 0.753 & 1.205 & 1.021 & 1.161 \\
\hline 261 & $K J 4202 D$ & 053 & 32 & 191 & 50 & 309 & 21 & 0.014839 & 0.013884 & 0.008357 & 0.0124 & 52.45 & 1.776 & 0.768 & 1.883 & 1.069 & 1.661 \\
\hline 262 & KJ4201B & 290 & 20 & 033 & 32 & 174 & 51 & 0.003897 & 0.003838 & 0.003352 & 0.0037 & 14.76 & 1.163 & 0.797 & 1.181 & 1.015 & 1.145 \\
\hline 283 & $\mathrm{KJ} 4202 \mathrm{~A}$ & 054 & 21 & 179 & 56 & 313 & 25 & 0.006355 & 0.006162 & 0.005340 & 0.0060 & 17.06 & 1.190 & 0.645 & 1.204 & 1.031 & 1.154 \\
\hline 264 & $\mathrm{KJ} 4202 \mathrm{C}$ & 066 & 36 & 205 & 46 & 319 & 21 & 0.013285 & 0.012894 & 0.010961 & 0.0124 & 18.77 & 1.212 & 0.689 & 1.230 & 1.030 & 1.176 \\
\hline 265 & KJ4203A & 251 & 19 & 001 & 44 & 145 & 40 & 0.009163 & 0.008912 & 0.007731 & 0.0086 & 16.64 & 1.185 & 0.673 & 1.200 & 1.028 & 1.153 \\
\hline 266 & $\mathrm{KJ} 4203 \mathrm{D}$ & 258 & 10 & 356 & 38 & 155 & 50 & 0.013202 & 0.012851 & 0.011146 & 0.0124 & 16.58 & 1.184 & 0.682 & 1.200 & 1.027 & 1.153 \\
\hline 267 & KJ4201D & 290 & 20 & 036 & 37 & 178 & 46 & 0.004873 & 0.004727 & 0.004053 & 0.0046 & 18.02 & 1.202 & 0.670 & 1.219 & 1.031 & 1.166 \\
\hline 268 & $K J 4203 C$ & 258 & 17 & 001 & 38 & 149 & 47 & 0.009718 & 0.009428 & 0.008073 & 0.0091 & 18.13 & 1.204 & 0.673 & 1.220 & 1.031 & 1.168 \\
\hline 269 & $\mathrm{KJ} 4222 \mathrm{C}$ & 015 & 13 & 128 & 59 & 278 & 27 & 0.000808 & 0.000791 & 0.000779 & 0.0008 & 3.64 & 1.037 & -0.123 & 1.037 & 1.021 & 1.016 \\
\hline 270 & $\mathrm{KJ} 4223 \mathrm{C}$ & 057 & 39 & 231 & 51 & 325 & 03 & 0.000816 & 0.000805 & 0.000802 & 0.0008 & 1.70 & 1.017 & -0.526 & 1.018 & 1.013 & 1.004 \\
\hline 271 & $\mathrm{KJ} 4221 \mathrm{C}$ & 056 & 22 & 155 & 20 & 282 & 60 & 0.000826 & 0.000813 & 0.000804 & 0.0008 & 2.76 & 1.028 & -0.167 & 1.028 & 1.016 & 1.012 \\
\hline 272 & $\mathrm{KJ} 4222 \mathrm{D}$ & 005 & 22 & 126 & 52 & 262 & 29 & 0.000804 & 0.000785 & 0.000774 & 0.0008 & 3.85 & 1.039 & -0.264 & 1.040 & 1.025 & 1.014 \\
\hline 273 & $\mathrm{KJ} 4221 \mathrm{~A}$ & 021 & 16 & 113 & 08 & 224 & 73 & 0.001000 & 0.000974 & 0.000957 & 0.0010 & 4.42 & 1.045 & -0.211 & 1.045 & 1.027 & 1.018 \\
\hline 274 & $K J 4222 B$ & 016 & 20 & 141 & 58 & 276 & 24 & 0.000762 & 0.000747 & 0.000736 & 0.0007 & 3.37 & 1.034 & -0.161 & 1.034 & 1.020 & 1.014 \\
\hline 275 & $\mathrm{KJ} 4223 \mathrm{~B}$ & 039 & 39 & 154 & 27 & 268 & 39 & 0.000826 & 0.000816 & 0.000809 & 0.0008 & 2.14 & 1.022 & -0.219 & 1.022 & 1.013 & 1.008 \\
\hline 276 & $K J 4221 B$ & 015 & 23 & 281 & 08 & 173 & 65 & 0.001102 & 0.001077 & 0.001063 & 0.0011 & 3.63 & 1.037 & -0.264 & 1.037 & 1.023 & 1.013 \\
\hline 277 & KJ4223A & 036 & 37 & 156 & 33 & 274 & 35 & 0.000735 & 0.000726 & 0.000715 & 0.0007 & 2.70 & 1.027 & 0.118 & 1.027 & 1.012 & 1.015 \\
\hline 278 & $\mathrm{KJ} 4221 \mathrm{~A}$ & 348 & 04 & 100 & 78 & 258 & 11 & 0.000701 & 0.000684 & 0.000678 & 0.0007 & 3.31 & 1.034 & -0.492 & 1.035 & 1.025 & 1.008 \\
\hline 279 & $\mathrm{KJ} 4234 \mathrm{~A}$ & 256 & 37 & 061 & 52 & 160 & 07 & 0.000112 & 0.000111 & 0.000098 & 0.0001 & 13.16 & 1.144 & 0.881 & 1.163 & 1.008 & 1.135 \\
\hline 280 & KJ4232A & 207 & 56 & 046 & 33 & 310 & 09 & 0.000124 & 0.000121 & 0.000108 & 0.0001 & 13.70 & 1.149 & 0.659 & 1.161 & 1.024 & 1.122 \\
\hline
\end{tabular}

Tab. 5.1. Dados de ASM.

Coordenadas geográficas e escalares de $\mathrm{K} 1, \mathrm{~K} 2$ e K3, valores de susceptibilidade e parâmetros de anisotropia magnética. 


\begin{tabular}{|c|c|c|c|c|c|c|c|c|c|c|c|c|c|c|c|c|c|}
\hline & Amostra & $A z K 1$ & $M K \hat{~}$ & $\mathrm{~A} z \mathrm{~K} 2$ & MK2 & $A z K 3$ & $M K 3$ & $K 1$ & $\mathrm{~K} 2$ & K3 & $\mathrm{km}$ & $\mathrm{H}$ & $P$ & $T$ & $P^{\prime}$ & $L$ & $F$ \\
\hline 281 & KJ4231 & 069 & 21 & 227 & 68 & 336 & 08 & 0.000105 & 0.000101 & 0.000098 & 0.0001 & 6.07 & 1.063 & -0.072 & 1.063 & 1.033 & 1.029 \\
\hline 282 & KJ4235B & 076 & 37 & 296 & 46 & 183 & 21 & 0.000109 & 0.000108 & 0.000096 & 0.0001 & 11.92 & 1.129 & 0.900 & 1.147 & 1.006 & 1.122 \\
\hline 283 & $K J 4235$ & 082 & 15 & 320 & 64 & 177 & 21 & 0.000111 & 0.000110 & 0.000098 & 0.0001 & 12.08 & 1.131 & 0.853 & 1.147 & 1.009 & 1.121 \\
\hline 284 & KJ4234 & 070 & 24 & 283 & 62 & 166 & 13 & 0.000105 & 0.000104 & 0.000093 & 0.0001 & 11.88 & 1.129 & 0.970 & 1.149 & 1.002 & 1.127 \\
\hline 285 & KJ4231 & 242 & 09 & 139 & 54 & 338 & 35 & 0.000088 & 0.000086 & 0.000080 & 0.0001 & 8.88 & 1.094 & 0.470 & 1.097 & 1.024 & 1.068 \\
\hline 286 & $K J 4234$ & 298 & 65 & 077 & 19 & 172 & 15 & 0.000077 & 0.000077 & 0.000068 & 0.0001 & 12.09 & 1.131 & 0.911 & 1.150 & 1.005 & 1.125 \\
\hline 287 & $K J 4236$ & 354 & 63 & 088 & 02 & 179 & 27 & 0.000097 & 0.000096 & 0.000083 & 0.0001 & 15.27 & 1.169 & 0.836 & 1.190 & 1.013 & 1.154 \\
\hline 288 & $\mathrm{KJ4241A}$ & 088 & 48 & 200 & 18 & 304 & 36 & 0.001150 & 0.001118 & 0.000847 & 0.0010 & 29.18 & 1.358 & 0.814 & 1.403 & 1.029 & 1.320 \\
\hline 289 & $\mathrm{KJ4241B}$ & 117 & 56 & 212 & 03 & 304 & 34 & 0.001204 & 0.001151 & 0.000873 & 0.0011 & 30.80 & 1.380 & 0.718 & 1.418 & 1.046 & 1.319 \\
\hline 290 & $\mathrm{KJ} 4241 \mathrm{C}$ & 135 & 57 & 040 & 03 & 308 & 32 & 0.001420 & 0.001317 & 0.001073 & 0.0013 & 27.28 & 1.323 & 0.461 & 1.336 & 1.078 & 1.227 \\
\hline 291 & $\mathrm{KJ} 4242 \mathrm{Ae}$ & 127 & 31 & 224 & 12 & 332 & 56 & 0.000474 & 0.000470 & 0.000429 & 0.0005 & 9.93 & 1.106 & 0.829 & 1.118 & 1.009 & 1.096 \\
\hline 292 & KJ4242B & 106 & 33 & 214 & 25 & 334 & 47 & 0.000754 & 0.000723 & 0.000587 & 0.0007 & 24.22 & 1.284 & 0.672 & 1.308 & 1.042 & 1.232 \\
\hline 293 & $\mathrm{KJ} 4242 \mathrm{C}$ & 139 & 30 & 044 & 08 & 301 & 58 & 0.000466 & 0.000434 & 0.000400 & 0.0004 & 15.22 & 1.165 & 0.077 & 1.165 & 1.073 & 1.086 \\
\hline 294 & KJ4243A & 129 & 60 & 031 & 04 & 299 & 29 & 0.001873 & 0.001718 & 0.001411 & 0.0017 & 27.71 & 1.327 & 0.389 & 1.337 & 1.090 & 1.217 \\
\hline 295 & $\mathrm{KJ} 4244 \mathrm{~A}$ & 161 & 52 & 062 & 07 & 327 & 37 & 0.002895 & 0.002574 & 0.001728 & 0.0024 & 48.63 & 1.675 & 0.544 & 1.722 & 1.125 & 1.489 \\
\hline 296 & $\mathrm{KJ} 4244 \mathrm{Be}$ & 149 & 51 & 242 & 03 & 334 & 39 & 0.002508 & 0.002257 & 0.001598 & 0.0021 & 42.85 & 1.569 & 0.531 & 1.606 & 1.112 & 1.412 \\
\hline 297 & $\mathrm{KJ} 4244 \mathrm{C}$ & 152 & 51 & 245 & 02 & 336 & 39 & 0.002031 & 0.001933 & 0.001388 & 0.0018 & 36.07 & 1.464 & 0.738 & 1.515 & 1.051 & 1.392 \\
\hline 298 & KJ4253A & 251 & 08 & 093 & 81 & 342 & 03 & 0.154203 & 0.095808 & 0.082793 & 0.1109 & 64.80 & 1.863 & -0.530 & 1.924 & 1.610 & 1.157 \\
\hline 299 & KJ4254A & 303 & 17 & 192 & 48 & 046 & 36 & 0.000049 & 0.000031 & 0.000029 & 0.0000 & 53.21 & 1.658 & -0.796 & 1.752 & 1.575 & 1.053 \\
\hline 300 & $K J 4252 B$ & 252 & 16 & 109 & 70 & 346 & 11 & 0.185807 & 0.125656 & 0.114551 & 0.1420 & 50.18 & 1.622 & -0.617 & 1.676 & 1.479 & 1.097 \\
\hline 301 & $K J 4253 C$ & 247 & 11 & 094 & 77 & 339 & 06 & 0.137875 & 0.089323 & 0.084502 & 0.1039 & 51.37 & 1.632 & -0.773 & 1.715 & 1.544 & 1.057 \\
\hline 302 & $K J 4252 C$ & 247 & 23 & 105 & 61 & 344 & 16 & 0.186694 & 0.128752 & 0.115354 & 0.1436 & 49.68 & 1.618 & -0.544 & 1.661 & 1.450 & 1.116 \\
\hline 303 & KJ4251B & 301 & 11 & 162 & 75 & 033 & 10 & 0.172128 & 0.117850 & 0.106009 & 0.1320 & 50.09 & 1.624 & -0.563 & 1.670 & 1.461 & 1.112 \\
\hline 304 & KJ4251D & 305 & 07 & 175 & 79 & 036 & 09 & 0.192940 & 0.127747 & 0.111899 & 0.1442 & 56.20 & $\$ .724$ & -0.514 & 1.772 & 1.510 & 1.142 \\
\hline 305 & $K J 4251 \mathrm{~A}$ & 063 & 12 & 291 & 73 & 155 & 13 & 0.172990 & 0.122374 & 0.111722 & 0.1357 & 45.15 & 1.548 & -0.583 & 1.590 & 1.414 & 1.095 \\
\hline 306 & KJ4254AY & 301 & 17 & 164 & 67 & 036 & 15 & 0.045390 & 0.028693 & 0.027917 & 0.0340 & 51.39 & 1.626 & -0.887 & 1.733 & 1.582 & 1.028 \\
\hline 307 & $K J 4254 C$ & 301 & 15 & 182 & 61 & 037 & 25 & 0.030186 & 0.027158 & 0.019234 & 0.0255 & 42.85 & 1.569 & 0.531 & 1.606 & 1.112 & 1.412 \\
\hline 308 & KJ4252A & 249 & 19 & 108 & 66 & 344 & 14 & 0.188310 & 0.127615 & 0.116375 & 0.1441 & 49.92 & 1.618 & -0.617 & 1.672 & 1.476 & 1.097 \\
\hline 309 & $K J 4252 D$ & 252 & 16 & 123 & 65 & 348 & 18 & 0.163075 & 0.108333 & 0.095504 & 0.1223 & 55.25 & 1.708 & -0.529 & 1.756 & 1.505 & 1.134 \\
\hline 310 & $\mathrm{KJ} 4251 \mathrm{C}$ & 304 & 08 & 160 & 81 & 035 & 05 & 0.179412 & 0.119760 & 0.103428 & 0.1342 & 56.62 & 1.735 & -0.468 & 1.776 & 1.498 & 1.158 \\
\hline 311 & $K J 4254 D$ & 298 & 11 & 202 & 28 & 047 & 59 & 0.023048 & 0.016237 & 0.015404 & 0.0182 & 41.93 & 1.496 & -0.739 & 1.553 & 1.419 & 1.054 \\
\hline 312 & $K J 4272 B$ & 091 & 46 & 188 & 07 & 285 & 44 & 0.000404 & 0.000385 & 0.000381 & 0.0004 & 6.01 & 1.062 & -0.581 & 1.065 & 1.048 & 1.013 \\
\hline 313 & KJ4272 & 117 & 28 & 019 & 14 & 265 & 58 & 0.000469 & 0.000433 & 0.000410 & 0.0004 & 13.40 & 1.143 & -0.206 & 1.144 & 1.084 & 1.054 \\
\hline 314 & KJ4274 & 059 & 12 & 156 & 27 & 308 & 60 & 0.000459 & 0.000456 & 0.000453 & 0.0005 & 1.31 & 1.013 & -0.065 & 1.013 & 1.007 & 1.006 \\
\hline 315 & KJ4321 & 061 & 16 & 156 & 15 & 287 & 67 & 0.085381 & 0.068413 & 0.052449 & 0.0687 & 47.90 & 1.628 & 0.091 & 1.633 & 1.248 & 1.304 \\
\hline 316 & $K J 4322$ & 058 & 13 & 153 & 22 & 300 & 64 & 0.070849 & 0.054481 & 0.046300 & 0.0572 & 42.91 & 1.530 & -0.235 & 1.539 & 1.300 & 1.177 \\
\hline 317 & $K J 4323$ & 054 & 29 & 188 & 51 & 310 & 23 & 0.000704 & 0.000675 & 0.000674 & 0.0007 & 4.35 & 1.044 & -0.930 & 1.050 & 1.043 & 1.002 \\
\hline 318 & KJ4324 & 060 & 21 & 154 & 10 & 269 & 67 & 0.044138 & 0.036859 & 0.029403 & 0.0368 & 40.04 & 1.501 & 0.113 & 1.504 & 1.197 & 1.254 \\
\hline 319 & $\mathrm{KJ} 4325$ & 060 & 41 & 155 & 06 & 253 & 48 & 0.000784 & 0.000726 & 0.000720 & 0.0007 & 8.61 & 1.089 & -0.780 & 1.098 & 1.079 & 1.009 \\
\hline 320 & $K J 4326$ & 026 & 11 & 122 & 29 & 278 & 59 & 0.020778 & 0.019784 & 0.018478 & 0.0197 & 11.69 & 1.125 & 0.165 & 1.125 & 1.050 & 1.071 \\
\hline
\end{tabular}

Tab. 5. 1. Dados de ASM

Coordenadas geográficas e escalares de $\mathrm{K} 1, \mathrm{~K} 2$ e K3, valores de susceptibilidade e parâmetros de anisotropia magnética. 


\begin{tabular}{|c|c|c|c|c|c|c|c|c|c|c|c|c|c|c|c|c|c|}
\hline & Amostra & $\mathrm{Az} K 1$ & $\mathrm{MK} 1$ & $\mathrm{Az} K 2$ & $M K 2$ & $A z K 3$ & $M K 3$ & $\mathrm{~K}_{1}$ & $\mathrm{~K} 2$ & K3 & $\mathrm{Km}$ & $\mathrm{H}$ & $P$ & $T$ & $P^{\prime}$ & $L$ & $F$ \\
\hline 321 & $K \sqrt{ } 4327$ & 243 & 03 & 336 & 40 & 150 & 50 & 0.000339 & 0.000331 & 0.000322 & 0.0003 & 4.97 & 1.051 & 0.043 & 1.051 & 1.024 & 1.026 \\
\hline 322 & $K J 4328$ & 065 & 01 & 335 & 33 & 156 & 57 & 0.000262 & 0.000257 & 0.000249 & 0.0003 & 5.04 & 1.052 & 0.155 & 1.052 & 1.022 & 1.030 \\
\hline 323 & KJ4329 & 065 & 17 & 330 & 15 & 200 & 67 & 0.000306 & 0.000297 & 0.000291 & 0.0003 & 4.89 & 1.050 & -0.162 & 1.050 & 1.029 & 1.021 \\
\hline 324 & KJ43210 & 069 & 07 & 337 & 15 & 182 & 73 & 0.000335 & 0.000326 & 0.000316 & 0.0003 & 5.73 & 1.059 & 0.051 & 1.059 & 1.028 & 1.031 \\
\hline 325 & KJ43211 & 054 & 12 & 320 & 20 & 174 & 66 & 0.000311 & 0.000302 & 0.000296 & 0.0003 & 4.88 & 1.050 & -0.160 & 1.050 & 1.029 & 1.021 \\
\hline 326 & $K J 4331$ & 091 & 56 & 228 & 26 & 329 & 20 & 0.002067 & 0.001890 & 0.001683 & 0.0019 & 20.39 & 1.228 & 0.129 & 1.229 & 1.094 & 1.123 \\
\hline 327 & KJ4333 & 126 & 61 & 036 & 00 & 306 & 29 & 0.006416 & 0.005972 & 0.004487 & 0.0056 & 34.29 & 1.430 & 0.599 & $1.46 !$ & 1.074 & 1.331 \\
\hline 328 & KJ4334 & 245 & 17 & 127 & 55 & 345 & 29 & 0.093067 & 0.086748 & 0.076347 & 0.0854 & 19.58 & 1.219 & 0.290 & 1.223 & 1.073 & 1.136 \\
\hline 329 & KJ4335 & 075 & 51 & 200 & 25 & 304 & 27 & 0.006673 & 0.006440 & 0.005213 & 0.0061 & 23.91 & 1.280 & 0.712 & 1.307 & 1.036 & 1.235 \\
\hline 330 & KJ4336 & 078 & 23 & 231 & 64 & 343 & 10 & 0.003639 & 0.003333 & 0.003129 & 0.0034 & 15.16 & 1.163 & -0.165 & 1.164 & 1.092 & 1.085 \\
\hline 331 & KJ4337 & 071 & 27 & 182 & 35 & 313 & 43 & 0.024788 & 0.023555 & 0.018705 & 0.0223 & 27.22 & 1.325 & 0.637 & 1.351 & 1.052 & 1.259 \\
\hline 332 & KJ43338 & 076 & 47 & 191 & 22 & 297 & 35 & 0.014067 & 0.013587 & 0.010327 & 0.0127 & 29.54 & 1.362 & 0.775 & 1.404 & 1.035 & 1.316 \\
\hline 333 & KJ4339 & 097 & 57 & 198 & 07 & 292 & 32 & 0.102064 & 0.090176 & 0.052050 & 0.0814 & 61.42 & 1.961 & 0.632 & 2.062 & 1.132 & 1.732 \\
\hline 334 & $K J 43310$ & 202 & 12 & 101 & 44 & 303 & 43 & 0.028668 & 0.026991 & 0.022251 & 0.0260 & 24.71 & 1.288 & 0.524 & 1.304 & 1.062 & 1.213 \\
\hline 335 & KJ43311 & 102 & 54 & 198 & 04 & 291 & 36 & 0.083633 & 0.077060 & 0.048407 & 0.0697 & 50.54 & 1.728 & 0.701 & 1.811 & 1.085 & 1.592 \\
\hline 336 & $\mathrm{KJ} 43312$ & 093 & 38 & 189 & 08 & 289 & 51 & 0.022533 & 0.020476 & 0.011979 & 0.0183 & 57.58 & 1.881 & 0.697 & 1.987 & 1.100 & 1.709 \\
\hline 337 & $\mathrm{KJ} 43313$ & 175 & 58 & 044 & 22 & 304 & 21 & 0.003818 & 0.003745 & 0.002427 & 0.0033 & 41.76 & 1.573 & 0.915 & 1.673 & 1.019 & 1.543 \\
\hline 338 & KJ4341 & 058 & 17 & 155 & 22 & 293 & 62 & 0.008730 & 0.007579 & 0.005478 & 0.0073 & 44.78 & 1.594 & 0.393 & 1.616 & 1.152 & 1.384 \\
\hline 339 & $K J 43422$ & 073 & 20 & 172 & 23 & 305 & 59 & 0.018414 & 0.016156 & 0.010400 & 0.0150 & 53.46 & 1.771 & 0.542 & 1.827 & 1.140 & 1.553 \\
\hline 340 & KJ4343 & 072 & 19 & 170 & 21 & 304 & 60 & 0.022535 & 0.019727 & 0.012727 & 0.0183 & 53.51 & 1.771 & 0.534 & 1.826 & 1.142 & 1.550 \\
\hline 341 & $K J 4343 B$ & 073 & 19 & 170 & 20 & 303 & 62 & 0.018977 & 0.016086 & 0.009938 & 0.0150 & 60.26 & 1.910 & 0.489 & 1.970 & 1.180 & 1.619 \\
\hline 342 & KJ4344 & 075 & 19 & 172 & 17 & 301 & 64 & 0.018146 & 0.013910 & 0.008684 & 0.0136 & 69.67 & 2.089 & 0.279 & 2.126 & 1.305 & 1.602 \\
\hline 343 & $K J 4344 B$ & 067 & 16 & 162 & 17 & 298 & 66 & 0.015554 & 0.012190 & 0.007446 & 0.0117 & 69.12 & 2.089 & 0.338 & 2.135 & 1.276 & 1.637 \\
\hline 344 & KJ4345 & 056 & 16 & 153 & 24 & 295 & 60 & 0.024380 & 0.020931 & 0.014421 & 0.0199 & 50.02 & 1.691 & 0.419 & 1.722 & 1.165 & 1.451 \\
\hline 345 & $K J 4346$ & 062 & 17 & 161 & 28 & 303 & 56 & 0.016489 & 0.013637 & 0.008962 & 0.0130 & 57.77 & 1.840 & 0.377 & 1.875 & 1.209 & 1.522 \\
\hline 346 & KJ4347 & 066 & 17 & 164 & 27 & 308 & 58 & 0.005154 & 0.004775 & 0.003634 & 0.0045 & 33.62 & 1.418 & 0.562 & 1.445 & 1.080 & 1.314 \\
\hline 347 & KJ4348 & 073 & 18 & 171 & 24 & 310 & 59 & 0.016652 & 0.013512 & 0.007996 & 0.0127 & 68.05 & 2.083 & 0.430 & 2.147 & 1.232 & 1.690 \\
\hline 348 & KJ4349 & 065 & 21 & 166 & 25 & 301 & 56 & 0.015660 & 0.012997 & 0.008573 & 0.0124 & 57.11 & 1.827 & 0.381 & 1.862 & 1.205 & 1.516 \\
\hline 349 & KJ43410 & 074 & 20 & 174 & 24 & 309 & 58 & 0.023046 & 0.019256 & 0.011218 & 0.0178 & 66.30 & 2.054 & 0.501 & 2.132 & 1.197 & 1.717 \\
\hline 350 & KJ43411 & 060 & 05 & 154 & 40 & 324 & 49 & 0.003809 & 0.003467 & 0.002975 & 0.0034 & 24.42 & 1.280 & 0.239 & 1.284 & 1.099 & 1.166 \\
\hline 351 & $K J 4351$ & 048 & 09 & 269 & 78 & 140 & 08 & 0.000751 & 0.000749 & 0.000700 & 0.0007 & 7.02 & 1.074 & 0.909 & 1.083 & 1.003 & 1.070 \\
\hline 352 & KJ4352 & 038 & 21 & 270 & 58 & 137 & 23 & 0.002395 & 0.002296 & 0.001960 & 0.0022 & 19.66 & 1.222 & 0.578 & 1.236 & 1.043 & 1.172 \\
\hline 353 & KJ4353A & 049 & 07 & 257 & 83 & 140 & 03 & 0.000360 & 0.000352 & 0.000338 & 0.0004 & 6.35 & 1.066 & 0.271 & 1.067 & 1.023 & 1.041 \\
\hline 354 & KJ4353B & 226 & 05 & 065 & 85 & 316 & 02 & 0.000400 & 0.000393 & 0.000376 & 0.0004 & 6.02 & 1.062 & 0.464 & 1.065 & 1.016 & 1.045 \\
\hline 355 & KJ4354 & 033 & 29 & 219 & 61 & 125 & 02 & 0.002166 & 0.001913 & 0.001543 & 0.0019 & 33.22 & 1.403 & 0.267 & 1.410 & 1.132 & 1.239 \\
\hline 356 & KJ4355 & 235 & 84 & 041 & 06 & 132 & 01 & 0.001586 & 0.001550 & 0.001403 & 0.0015 & 12.07 & 1.130 & 0.626 & 1.139 & 1.023 & 1.105 \\
\hline 357 & KJ4356A & 217 & 35 & 051 & 54 & 312 & 07 & 0.001132 & 0.000972 & 0.000669 & 0.0009 & 50.02 & 1.691 & 0.419 & 1.722 & 1.165 & 1.451 \\
\hline 358 & KJ4356B & 209 & 51 & 045 & 38 & 309 & 08 & 0.000823 & 0.000795 & 0.000715 & 0.0008 & 13.89 & 1.151 & 0.502 & 1.158 & 1.036 & 1.111 \\
\hline 359 & KJ4361A & 060 & 30 & 176 & 37 & 303 & 39 & 0.000580 & 0.000576 & 0.000535 & 0.0006 & 7.91 & 1.083 & 0.844 & 1.093 & 1.006 & 1.077 \\
\hline 360 & $K J 43618$ & 136 & 50 & 032 & 11 & 293 & 37 & 0.000578 & 0.000571 & 0.000520 & 0.0006 & 10.54 & 1.113 & 0.746 & 1.123 & 1.014 & 1.098 \\
\hline
\end{tabular}

Táb. 5.1. Dados de ASM.

Coordenadas geográficas e escalares de $\mathrm{K} 1, \mathrm{~K} 2$ e $\mathrm{K} 3$, valores de susceptibilidacie e parâmetros de anisotropia magnética. 


\begin{tabular}{|c|c|c|c|c|c|c|c|c|c|c|c|c|c|c|c|c|c|}
\hline & Amostra & $\mathrm{Az} K 1$ & $M K 1$ & $\mathrm{Az} \mathrm{K} 2$ & $M K 2$ & $A \geq K 3$ & M K3 & K1 & $\mathrm{K} 2$ & K3 & $\mathrm{km}$ & H & $P$ & $T$ & $P^{2}$ & L & $F$ \\
\hline 361 & KJ4362 & 127 & 48 & 030 & 06 & 295 & 41 & 0.000430 & 0.000427 & 0.000394 & 0.0004 & 8.78 & 1.093 & 0.840 & 1.104 & 1.007 & 1.085 \\
\hline 362 & $K J 4363$ & 049 & 11 & 151 & 46 & 309 & 42 & 0.000398 & 0.000394 & 0.000368 & 0.0004 & 7.63 & 1.080 & 0.785 & 1.088 & 1.008 & 1.071 \\
\hline 363 & KJ4364 & 088 & 48 & 199 & 18 & 303 & 36 & 0.000530 & 0.000510 & 0.000488 & 0.0005 & 8.36 & 1.087 & 0.081 & 1.087 & 1.039 & 1.046 \\
\hline 364 & KJ4365 & 159 & 46 & 044 & 22 & 297 & 35 & 0.000857 & 0.000832 & 0.000639 & 0.0008 & 28.08 & 1.341 & 0.794 & 1.382 & 1.031 & 1.301 \\
\hline 365 & KJ4366 & 107 & 54 & 212 & 11 & 309 & 33 & 0.000334 & 0.000321 & 0.000286 & 0.0003 & 15.28 & 1.168 & 0.488 & 1.176 & 1.041 & 1.122 \\
\hline 366 & $\mathrm{KJ} 4367 \mathrm{~A}$ & 180 & 36 & 059 & 36 & 300 & 34 & 0.001941 & 0.001861 & 0.001490 & 0.0018 & 25.53 & 1.302 & 0.684 & 1.329 & 1.043 & 1.249 \\
\hline 367 & KJ4367B & 177 & 34 & 053 & 39 & 292 & 32 & 0.001037 & 0.000990 & 0.000797 & 0.0009 & 25.47 & 1.301 & 0.648 & 1.325 & 1.047 & 1.242 \\
\hline 368 & KJ4368 & 175 & 41 & 052 & 32 & 298 & 33 & 0.000634 & 0.000618 & 0.000505 & 0.0006 & 22.03 & 1.256 & 0.776 & 1.284 & 1.026 & 1.224 \\
\hline 369 & KJ4381A & 006 & 40 & 214 & 46 & 109 & 15 & 0.000385 & 0.000381 & 0.000376 & 0.0004 & 2.45 & 1.025 & 0.067 & 1.025 & 1.011 & 1.013 \\
\hline 370 & KJ4381B & 356 & 38 & 191 & 51 & 092 & 08 & 0.000348 & 0.000345 & 0.000340 & 0.0003 & 2.27 & 1.023 & 0.423 & 1.024 & 1.007 & 1.016 \\
\hline 371 & $\mathrm{KJ} 4381 \mathrm{C}$ & 017 & 35 & 214 & 54 & 112 & 08 & 0.000518 & 0.000514 & 0.000504 & 0.0005 & 2.84 & 1.029 & 0.386 & 1.030 & 1.009 & 1.020 \\
\hline 372 & $\mathrm{KJ} 4382 \mathrm{~A}$ & 024 & 22 & 119 & 10 & 232 & 65 & 0.000473 & 0.000465 & 0.000455 & 0.0005 & 3.86 & 1.039 & 0.118 & 1.039 & 1.017 & 1.022 \\
\hline 373 & KJ4382B & 025 & 28 & 290 & 10 & 182 & 60 & 0.000497 & 0.000491 & 0.000483 & 0.0005 & 2.98 & 1.030 & 0.068 & 1.030 & 1.014 & 1.016 \\
\hline 374 & $\mathrm{KJ} 4382 \mathrm{C}$ & 012 & 32 & 109 & 13 & 218 & 55 & 0.000394 & 0.000387 & 0.000381 & 0.0004 & 3.44 & 1.035 & -0.079 & 1.035 & 1.019 & 1.016 \\
\hline 375 & KJ4383A & 030 & 23 & 123 & 06 & 227 & 66 & 0.000446 & 0.000440 & 0.000432 & 0.0004 & 3.15 & 1.032 & 0.189 & 1.032 & 1.013 & 1.019 \\
\hline 376 & KJ4383B & 026 & 17 & 295 & 02 & 198 & 72 & 0.000461 & 0.000453 & 0.000447 & 0.0005 & 3.06 & 1.031 & -0.149 & 1.031 & 1.018 & 1.013 \\
\hline 377 & $\mathrm{KJ} 4383 \mathrm{C}$ & 026 & 11 & 120 & 19 & 267 & 67 & 0.000582 & 0.000569 & 0.000561 & 0.0006 & 3.64 & 1.037 & -0.239 & 1.037 & 1.023 & 1.014 \\
\hline 378 & $\mathrm{KJ} 4384 \mathrm{~A}$ & 016 & 28 & 281 & 10 & 173 & 60 & 0.000441 & 0.000432 & 0.000424 & 0.0004 & 3.88 & 1.040 & -0.042 & 1.040 & 1.020 & 1.019 \\
\hline 379 & KJ4384B & 006 & 20 & 103 & 19 & 233 & 62 & 0.000519 & 0.000511 & 0.000503 & 0.0005 & 3.12 & 1.032 & 0.078 & 1.032 & 1.014 & 1.017 \\
\hline 380 & $\mathrm{KJ} 4384 \mathrm{C}$ & 008 & 22 & 110 & 26 & 243 & 54 & 0.000573 & 0.000565 & 0.000556 & 0.0006 & 3.00 & 1.030 & 0.008 & 1.030 & 1.015 & 1.015 \\
\hline 381 & KJ444B2A & 259 & 18 & 024 & 61 & 162 & 23 & 0.000128 & 0.000125 & 0.000118 & 0.0001 & 8.30 & 1.087 & 0.341 & 1.089 & 1.028 & 1.058 \\
\hline 382 & $K J 444 B 2 b$ & 019 & 50 & 274 & 13 & 174 & 37 & 0.001018 & 0.000981 & 0.000922 & 0.0010 & 9.79 & 1.103 & 0.259 & 1.105 & 1.037 & 1.064 \\
\hline 383 & KJ444AA1A & 330 & 41 & 183 & 44 & 075 & 17 & 0.000248 & 0.000243 & 0.000234 & 0.0002 & 6.10 & 1.063 & 0.241 & 1.064 & 1.023 & 1.039 \\
\hline 384 & $K J 444 A 3$ & 127 & 60 & 316 & 30 & 223 & 04 & 0.000098 & 0.000092 & 0.000082 & 0.0001 & 17.65 & 1.195 & 0.248 & 1.197 & 1.069 & 1.117 \\
\hline 385 & KJ444A3B & 114 & 56 & 344 & 23 & 243 & 23 & 0.000072 & 0.000071 & 0.000069 & 0.0001 & 5.62 & 1.058 & 0.259 & 1.059 & 1.021 & 1.036 \\
\hline 386 & $\mathrm{KJ444A1B}$ & 126 & 23 & 359 & 54 & 228 & 26 & 0.000359 & 0.000350 & 0.000321 & 0.0003 & 11.04 & 1.118 & 0.521 & 1.124 & 1.027 & 1.088 \\
\hline 387 & $K J 4454 A$ & 067 & 31 & 173 & 24 & 294 & 50 & 0.000186 & 0.000184 & 0.000177 & 0.0002 & 4.60 & 1.047 & 0.654 & 1.051 & 1.008 & 1.039 \\
\hline 388 & $\mathrm{KJ} 4453 \mathrm{~A}$ & 050 & 42 & 158 & 19 & 266 & 42 & 0.000683 & 0.000683 & 0.000679 & 0.0007 & 0.68 & 1.007 & 0.619 & 1.007 & 1.001 & 1.006 \\
\hline 389 & $\mathrm{KJ} 4451 \mathrm{~A}$ & 130 & 37 & 022 & 22 & 268 & 45 & 0.000204 & 0.000203 & 0.000190 & 0.0002 & 7.44 & 1.078 & 0.782 & 1.086 & 1.008 & 1.069 \\
\hline 390 & $\mathrm{KJ4461 \textrm {A }}$ & 172 & 25 & 285 & 39 & 059 & 40 & 0.000048 & 0.000046 & 0.000045 & 0.0000 & 7.02 & 1.073 & 0.162 & 1.073 & 1.030 & 1.042 \\
\hline 391 & $\mathrm{~K} J 4462 \mathrm{~A}$ & 084 & 16 & 180 & 20 & 317 & 64 & 0.000518 & 0.000510 & 0.000476 & 0.0005 & 8.43 & 1.089 & 0.636 & 1.095 & 1.016 & 1.072 \\
\hline 392 & $K J 4463 A$ & 068 & 28 & 309 & 43 & 179 & 35 & 0.000253 & 0.000245 & 0.000236 & 0.0002 & 7.09 & 1.074 & 0.090 & 1.074 & 1.033 & 1.039 \\
\hline 393 & KJ4473A & 086 & 22 & 225 & 62 & 349 & 17 & 0.000404 & 0.000402 & 0.000398 & 0.0004 & 1.39 & 1.014 & 0.226 & 1.014 & 1.005 & 1.009 \\
\hline 394 & $\mathrm{KJ} 4471 \mathrm{~A}$ & 119 & 28 & 261 & 56 & 020 & 18 & 0.000194 & 0.000191 & 0.000188 & 0.0002 & 2.86 & 1.029 & 0.112 & 1.029 & 1.013 & 1.016 \\
\hline 395 & $\mathrm{KJ} 4471 \mathrm{~B}$ & 139 & 32 & 290 & 55 & 040 & 14 & 0.000180 & 0.000177 & 0.000177 & 0.0002 & 1.55 & 1.016 & -0.987 & 1.020 & 1.015 & 1.000 \\
\hline 396 & KJ4484A & 032 & 20 & 134 & 28 & 272 & 55 & 0.004647 & 0.003967 & 0.003053 & 0.0039 & 40.99 & 1.522 & 0.247 & 1.531 & 1.171 & 1.299 \\
\hline 397 & $\mathrm{KJ} 4484 \mathrm{~B}$ & 053 & 15 & 150 & 25 & 295 & 60 & 0.001066 & 0.000897 & 0.000771 & 0.0009 & 32.42 & 1.383 & -0.066 & 1.385 & 1.180 & 1.164 \\
\hline 398 & KJ448E1 & 065 & 38 & 210 & 46 & 320 & 18 & 0.000516 & 0.000486 & 0.000457 & 0.0005 & 12.15 & 1.129 & 0.023 & 1.129 & 1.061 & 1.064 \\
\hline 399 & KJ4491A & 100 & 38 & 352 & 22 & 239 & 44 & 0.000205 & 0.000204 & 0.000190 & 0.0002 & 7.13 & 1.075 & 0.859 & 1.084 & 1.005 & 1.069 \\
\hline 400 & KJ44958 & 126 & 28 & 219 & 03 & 311 & 42 & 0.000937 & 0.000910 & 0.000809 & 0.0009 & 14.47 & 1.158 & 0.598 & 1.168 & 1.030 & 1.125 \\
\hline
\end{tabular}

Tab. 5.1. Dados de ASM. 


\begin{tabular}{|c|c|c|c|c|c|c|c|c|c|c|c|c|c|c|c|c|c|}
\hline & Amostra & $\mathrm{AzK} 1$ & $M K 1$ & $A z K 2$ & $\mathrm{MK} 2$ & $A Z K 3$ & $M K 3$ & $\mathrm{~K} 1$ & $K 2$ & $\mathrm{~K} 3$ & $\mathrm{Km}$ & $H$ & $P$ & $T$ & $P^{\prime}$ & $L$ & $F$ \\
\hline 401 & KJ4497A & 064 & 47 & 168 & 12 & 268 & 40 & 0.000936 & 0.000866 & 0.000841 & 0.0009 & 10.77 & 1.113 & -0.444 & 1.117 & 1.080 & 1.030 \\
\hline 402 & $K J 4493 B$ & 090 & 14 & 205 & 60 & 353 & 27 & 0.000614 & 0.000608 & 0.000563 & 0.0006 & 8.67 & 1.092 & 0.767 & 1.101 & 1.010 & 1.081 \\
\hline 403 & $\mathrm{KJ} 4493 \mathrm{C}$ & 113 & 38 & 244 & 39 & 359 & 28 & 0.000629 & 0.000618 & 0.000611 & 0.0006 & 3.00 & 1.030 & -0.193 & 1.031 & 1.018 & 1.012 \\
\hline 404 & $\mathrm{KJ} 4496 \mathrm{~A}$ & 219 & 21 & 002 & 64 & 123 & 14 & 0.000872 & 0.000860 & 0.000849 & 0.0009 & 2.77 & 1.028 & -0.004 & 1.028 & 1.014 & 1.014 \\
\hline 405 & $\mathrm{KJ} 4497 \mathrm{C}$ & 164 & 57 & 030 & 24 & 290 & 21 & 0.000390 & 0.000379 & 0.000367 & 0.0004 & 6.05 & 1.062 & 0.083 & 1.063 & 1.028 & 1.033 \\
\hline 406 & KJ4493A & 266 & 01 & 095 & 89 & 356 & 00 & 0.000640 & 0.000626 & 0.000578 & 0.0006 & 10.16 & 1.108 & 0.567 & 1.114 & 1.022 & 1.084 \\
\hline 407 & KJ4501A & 190 & 01 & 280 & 39 & 100 & 51 & 0.174883 & $0 .\{41232$ & 0.130585 & 0.1489 & 29.75 & 1.339 & -0.463 & 1.354 & 1.238 & 1.082 \\
\hline 408 & KJ4501B & 189 & 12 & 090 & 37 & 294 & 51 & 0.223313 & 0.175236 & 0.164851 & 0.1878 & 31.13 & 1.355 & -0.597 & 1.380 & 1.274 & 1.083 \\
\hline 409 & $K J 4502 A$ & 254 & 11 & 150 & 52 & 352 & 36 & 0.116977 & 0.103933 & 0.088690 & 0.1032 & 27.41 & 1.319 & 0.146 & 1.321 & 1.126 & 1.172 \\
\hline 410 & $K J 45028$ & 243 & 20 & 123 & 54 & 345 & 29 & 0.089719 & 0.082871 & 0.073440 & 0.0820 & 19.65 & 1.222 & 0.207 & 1.224 & 1.083 & 1.128 \\
\hline 411 & KJ4503B & 054 & 07 & 151 & 47 & 318 & 43 & 0.225309 & 0.192508 & 0.173183 & 0.1970 & 26.46 & 1.301 & -0.196 & 1.304 & 1.170 & 1.112 \\
\hline 412 & KJ4503C & 049 & 06 & 147 & 51 & 314 & 38 & 0.187109 & 0.153407 & 0.137983 & 0.1595 & 30.80 & 1.356 & -0.304 & 1.363 & 1.220 & 1.112 \\
\hline 413 & KJ4504A & 043 & 14 & 141 & 28 & 289 & 58 & 0.084618 & 0.081347 & 0.079376 & 0.0818 & 6.41 & 1.066 & -0.233 & 1.067 & 1.040 & 1.025 \\
\hline 414 & $\mathrm{KJ} 4504 \mathrm{~B}$ & 227 & 23 & 113 & 44 & 336 & 38 & 0.082517 & 0.081333 & 0.077702 & 0.0805 & 5.98 & 1.062 & 0.519 & 1.065 & 1.015 & 1.047 \\
\hline 415 & KJ4505A & 241 & 13 & 131 & 56 & 339 & 31 & 0.232460 & 0.192708 & 0.164333 & 0.1965 & 34.67 & 1.415 & -0.081 & 1.416 & 1.206 & 1.173 \\
\hline 416 & KJ44505B & 239 & 17 & 136 & 37 & 350 & 48 & 0.221940 & 0.185616 & 0.157944 & 0.1885 & 33.95 & 1.405 & -0.051 & 1.407 & 1.196 & 1.175 \\
\hline 417 & $K J 4514 C$ & 209 & 05 & 117 & 18 & 313 & 72 & 0.000736 & 0.000699 & 0.000677 & 0.0007 & 8.37 & 1.087 & -0.213 & 1.088 & 1.052 & 1.033 \\
\hline 418 & KJ4513B & 033 & 14 & 134 & 37 & 286 & 49 & 0.000899 & 0.000793 & 0.000762 & 0.0008 & 16.88 & 1.180 & -0.514 & 1.189 & 1.133 & 1.041 \\
\hline 419 & $\mathrm{KJ} 4524 \mathrm{~A}$ & 153 & 18 & 245 & 05 & 351 & 71 & 0.059579 & 0.053330 & 0.050981 & 0.0546 & 15.74 & 1.169 & -0.422 & 1.174 & 1.117 & 1.046 \\
\hline 420 & $K J 4524 C$ & 133 & 25 & 025 & 33 & 252 & 47 & 0.055685 & 0.050495 & 0.043820 & 0.0500 & 23.73 & 1.271 & 0.183 & 1.273 & 1.103 & 1.152 \\
\hline 421 & $K_{3} 3543 \mathrm{~A}$ & 227 & 00 & 319 & 75 & 137 & 15 & 0.001922 & 0.001916 & 0.001648 & 0.0018 & 14.99 & 1.166 & 0.959 & 1.192 & 1.003 & 1.163 \\
\hline 422 & $K J 4543 B$ & 084 & 19 & 352 & 08 & 240 & 70 & 0.001915 & 0.001884 & 0.001631 & 0.0018 & 15.72 & 1.174 & 0.793 & 1.194 & 1.017 & 1.155 \\
\hline 423 & KJ4542C & 218 & 22 & 325 & 37 & 104 & 45 & 0.001418 & 0.001307 & 0.001254 & 0.0013 & 12.38 & 1.131 & -0.327 & 1.133 & 1.085 & 1.042 \\
\hline 424 & $K J 4542 B$ & 222 & 18 & 330 & 45 & 117 & 40 & 0.001502 & 0.001389 & 0.001321 & 0.0014 & 12.90 & 1.137 & -0.225 & 1.138 & 1.082 & 1.051 \\
\hline 425 & $K J 4542 \mathrm{~A}$ & 225 & 10 & 328 & 51 & 127 & 37 & 0.001441 & 0.001303 & 0.001276 & 0.0013 & 12.34 & 1.130 & -0.650 & 1.139 & 1.106 & 1.022 \\
\hline 426 & KJ4571A & 059 & 16 & 319 & 31 & 173 & 55 & 0.192940 & 0.127747 & 0.111899 & 0.1442 & 56.20 & 1.724 & -0.514 & 1.772 & 1.510 & 1.142 \\
\hline
\end{tabular}

Dados de atitudes de foliação e lineação magnéticas, susceptibilidades e parâmetros de anisotropia magnética. Amostra: identificação dos cilindros de rocha; Az: azimute; $\mathrm{M}$ : mergulho; $\mathrm{Km}$ : susceptibilidade magnética média da amostra, sendo que $\mathrm{Km}=(\mathrm{K} 1+\mathrm{K} 2+\mathrm{K} 3) / 3 ; \mathrm{K} 1, \mathrm{~K} 2, \mathrm{~K} 3$ : valores dos eixos máximo, intermediário e mínimo de ASM, (comprimento dos eixos do elipsóide de susceptibilidade magnética) onde $K 1>=K 2>=K 3$; $P$ (grau de anisotropia magnética), $P^{\prime}$ (grau de anisotropia magnética corrigido), $H$ (porcentagem de anisotropia), $T$ (parâmetro de forma), $L$ ( $K 1 / K 2$, lineação magnética), $F$ ( $K 2 / K 3$, foliação magnética). 


\section{Conclusões}

A concordância entre as atitudes de estruturas planares e lineares obtidas em campo, com as coordenadas geográficas dos auto-vetores de ASM, associada à caracterizaçäo da fábrica, pela identificação da forma e domínios de ocorrẽncia dos elipsóides de susceptibilidade, confirmam a Anisotropia de Susceptibilidade Magnética como importante ferramenta para análise estrutural, que possibilita a análise cinemática em rochas de alto grau metamórfico, como as aflorantes na área deste estudo.

A associação dos estudos petrográficos, dos métodos convencionais de estudo estrutural e da aplicação da ASM, de maneira diferenciada e específica, indicou um quadro cinemático para a área enfocada, que envolveu colisão frontal, de direção $E$ $\mathrm{W}$, de leste para oeste, gerando falhamentos de empurrão oblíquos, para oeste, associada a cisalhamento de direção NE, que causou movimento de massa de NE para SW, sob regime transpressivo.

Os dados obtidos através da análise das coordenadas geográficas dos autovetores de ASM indicaram transição entre domínio tangencial e direcional, na área. Nos domínios tangenciais, falhas de baixo mergulho causaram transporte de massa para $W$, associadas a deslizamentos direcionais ao longo de um plano de direção NE, de baixo merguiho (040/19). No domínio direcional, uma componente compressiva de direção SE/NW, promoveu deslocamento direcional oblíquo, ao longo de um plano de direçäo NE, de alto ângulo (043/59), que representa a estrutura principal da área, causando transporte de massa de NE para SW.

O quadro cinemático responsável pela configuração atual da área, com as principais direções de movimento e tensão, obtidas pela análise dos dados da ASM, sugere um modelo evolutivo de colisão frontal, sob regime convergente, em ambiente transpressivo, gerando falhamentos de empurrão que promoveram o deslizamento de rochas de profundidade, sobre rampas de baixo ângulo, em direção ao Cráton do São Francisco e, subseqüente deslizamento de massa na direçäo NE-SW, gerando transporte sub - horizontal de massa ao longo de uma zona de cisalhamento de atitude média N45E/60SE, onde ocorreram soerguimento, rotação e inversão dos blocos de rochas, que hoje afloram na regiảo. 


\section{Referências}

Almeida, F. F. M., 1967. Origem e evolução da Plataforma Brasileira. Divisão de Geologia e Mineração, DNPM- RJ Boletim 241: 1-36.

Almeida, F. F. M., 1969. Diferenciação tectônica da plataforma brasileira. in: XXIII Congresso Brasileiro de Geologia.

Almeida, F. F. M., 1971. Geochronological division of South America. Revista Brasileira de Geociências, 1: 13-21.

Almeida. F. F. M., Amaral, G., Cordani, U. G., Kawashita, K., 1973. The Precambrian evolution of the South American cratonic margin south of Amazon River, in: Nairn, E. M. \& Stheli, F. G. The oceans basin and margins. New York, Plenun. Publishers Company 1(11): $411-446$.

Almeida, F. F. M., Hasui, Y. \& Carneiro, C. D. R., 1976. O Lineamento Além Paraíba. Anais da Academia Brasileira de Ciências, 47:575.

Almeida, F. F. M., Hasui, Y. \& Brito Neves, B. B., 1976b. The Upper Precambrian of South America. IG-USP, 7: 45-80.

Almeida, F.F.M. , 1977. O Cráton do São Francisco. Revista Brasileira Geociências, 7 : 349-364.

Almeida, F. F. M., Hasui, Y., Brito Neves, B. B. \& Fuck, R. A., 1981. Brazilian structural provinces an introduction. Earth Science Reviews, 17: 1-29.

Almeida, F. F. M., Brito Neves, B. B. \& Carneiro, C. D. R., 2000. The origin and evolution of South American Platform. Earth Science Reviews, 50: 77 - 111.

Archanjo, C. J., 1993. Fabriques de plutons granitiques et déformation crustale du nordest du Brésil une étude par anisotropie de susceptihilité magnetique de granites ferromagnétiques. Doctorat thesis, Toulouse III.

Archanjo, C. J. \& Bouchez, J. L., 1994. The pombal granite emplacement and relationship slip setting of NE - Brazil. Geology, 16: 323-335.

Archanjo, C. J., Macedo, J. W. P., Galindo, A. C. \& Araújo, M. G. S., 1998. Brasiliano crustal extension and emplacement fabrics of the mangerite-charnockite pluton of Umarizal, North-east Brazil. Precambrian Research, 87: 19-32.

Archanjo, C. J., Silva, E. R. \& Caby, R., 1999. Magnetic fabric and pluton emplacement in a transpressive shear zone system: the Itaporanga porphyritic granitic pluton (northeast Brazil). Tectonophysics, 312: 331-345. 
Archanjo, C. J., Trindade, R. I., Macedo, J. W. P. \& Araújo, M., 2000. Magnetic fabric of a basaltic dik swarm associated with Mesozoic rifting in norteastern Brazil. Journal of South American Earth Sciences, 13: 179-189.

Banerjee, S.K., 1991. Magnetic properties of Fe-Ti Oxides. Reviews in mineralogy, Mineralogical Society of America, 25: 107-128.

Barbosa, A.L.M., Ribeiro, A.C., Pinto, C.P. Barros Dutra, J.E., Grossi Sad, J.H. \& Tuller, M.P., 1981. Projeto Carta Geológica do Estado do Rio de Janeiro, Folhas Cava, Miguel Pereira, Paraíba do Sul, Três Rios. DRM-RJ, 294p.

Barbosa, A.L.M. \& Grossi Sad, J.H., 1983. Reinterpretação das Séries Juiz de Fora e Paraíba, em Minas Gerais e Rio de Janeiro. in: II Simpósio de Geologia de Minas Gerais, Geologia do Pré cambriano, 3: 1-15.

Baptista, M.B., Braun, O.P. \& Campos, D.A., 1984. Léxico estratigráfico do Brasil. DGM/DNPM, 541p.

Batista, J. J., 1984. Caracterização dos processos geológico-evolutivos précambrianos na região de São Fidélis, Norte do Rio de Janeiro, Exame de Qualificação para Doutoramento, IG-USP.

Benn, K., Rochette, P., Bouchez, J.L. \& Hattori, K., 1993. Magnetic susceptibility, magnetic mineralogy and magnetic fabrics in a late Archaean granitoid-gneiss belt. Precambrian Research, 63: 59-81.

Bhatal, R. S., 1971. Magnetic anisotropy in rocks. Earth Science Reviews, 7: 227-253.

Borradaile, G. J., 1987. Anisotropy of susceptibility rock composition versus strain. Tectonophysics, 138: 327-329.

Borradaile, G. J., Alford, C. \& Sarvas, C. 1987. AMS of some metamorphic minerals. Phisycs of the Earth and Planetary Interiors, 48: 161 - 166.

Borradaile, G. J. \& Alford, C., 1987. Relationship between magnetic suscptibility and strain in laboratory experiments. Tectonophysics, 133: 121-135.

Borradaile, G. J., 1988. Magnetic susceptibiliy, petrofabrics and strain. Tectonophysics, 156: $1-20$.

Borradaile, G. J. \& Puumala, M. A., 1989. Synthetic magnetic susceptihility fabric in plasticene. Tetonophysics, 164: 73-78.

Borradaile, G. J., 1991. Correlation of strain with anisotropy of magnetic susceptibility. Pageoph, 135: 15-29.

Borradaile, G. J. \& Henry, B., 1997. Tectonic applications of magnetic susceptibility and its anisotropy. Earth Science Reviews, 42: 49-93.

Borradaile, G. J., Lagroix, F. \& King, D., 1998. Tilting and transpression of an archaean anorthosite in northern Ontario. Tectonophysics, 293: 239-254. 
Borradaile, G. J., Werner, T. \& Lagroix, F., 1999. Magnetic fabrics and anisotropycontrolled thrusting in the Kapuskasing Structural Zone, Canada. Tectonophysics, 302: $241-256$.

Borradaile, G. J., 2001. Magnetic fabrics and petrofabrics: their orientation distributions and anisotropies. Journal of structural geology, 23: $1581-1596$.

Bouchez, J. L., 1997. Granite is never anisotropic: an introdution to AMS studies of granitic rocks. in: Granite: From segregation of melt to emplacement fabrics, Kluwer Academic Publishers, Netherlands, 95-112.

Bouchez, J. L., 2000. Anisotropie de susceptibilité magnétique et fabrique des granites. Earth and Planetary Sciences, 330: 1-14.

Brandalise, L.A., Ribeiro, J.H. \& Ferrari, P. G. , 1976. Projeto Vale do Rio Paraíba do Sul, Relatório Final 590, DNPM/ CPRM- BH, $411 \mathrm{p}$.

Brenner, T.L., Ferrari, A. L. \& Penha, H. M., 1980. Lineamentos estruturais do Norte do Estado do Rio de Janeiro. in: XXXI CBG, SBG/SC, 5: 2551-2564.

Brüeckner, H.K., Cunningham, D., Alkmin, F., Marshak, S., 2000. Tectonic implications of Precambrian Sm-Nd dates from the southern São Francisco Craton and adjacent Araçuaí and Ribeira belts, Brazil. Precambrian Research, 99: 255-269.

Campanha, G. A. C., 1980. O Lineamento de Além Paraiba na área de Três Rios, RJ. Dissertação de Mestrado, IG - USP, 109 p.

Campanha, G. A. C., 1981. O lineamento de Além Paraíba na área de Três Rios, RJ. Revista Brasileira de Geociências, 11: 159-171.

Campos Neto, M. C., 1984. Geometria e fases de dobramentos superpostos no oeste de Minas Gerais. Revista Brasileira de Geociências, 14: 60-68.

Campos Neto, M.C. \& Flgueiredo, M.C.H., 1990. Evolução geológica dos terrenos Costeiro, Paraíba do Sul e Juiz de Fora RJ-MG-ES. in: XXXVI Congresso Brasilero de Geologia Natal, SBG-RN.

Campos Neto, M. C., Perrota, M. M., Peloggia, A. U. G. \& Figueiredo, M. C. H., 1990. A porção ocidental da faixa Alto Rio Grande SP-MG. in: XXXVI Congresso Brasileiro de Geologia. SBG/RN, 6: 2615-2630.

Campos Neto, M. C., 1991. A porção ocidental da Faixa Alto Rio Grande - Ensaio de Evolução Tectônica. Tese de Doutoramento. IG-USP. 210 p.

Campos Neto, M. C. \& Figueiredo, M. C. H., 1992. A Orogênese Rio Doce. in: XXXVII Congresso Brasileiro de Geologia. SBG-SP, SP, 276-277.

Campos Neto, M. C. \& Figueiredo, M. C. H., 1995. The Rio Doce Orogeny, Southeastern Brazil. Journal of South American Earth Sciences, 8: 143-162. 
Campos Neto, M. C., 2000. Orogenic systems from southernwestern Gondwana. in: Cordani et al., 2000, Tectonic Evolution of South America, p.335-365.

Campanha, G. A. C., 1980. O Lineamento Além Paraíba na área de Três Rios (RJ). Dissertação de Mestrdo, IG-USP, 109p.

Campanha, G. A. C., 1981. O Lineamento Além Paraíba na área de Três Rios (RJ). Revista Brasileira de Geociências, 11:159-171.

Campanha, G. A. C. \& Sadowski, G.R., 1999. Tectonics of the southern portion of the Ribeira Belt (Apiai Domain). Precambrian Research, 98: 31-51.

Castro, H. O., Queiroz, M. A., Barbosa, A. L. \& Grossi Sad, J. H., 1984. Geologia das folhas Rio Preto, Valença, Barra do Piraí e Vassouras. in: XXXIII Congresso Brasileiro de Geologia, SBG/RJ, Resumos, 127-128.

Chrispim, S. J. \& Tupinambá, M., 1989. Observações sobre o carácter transpressivo da deformação entre as zonas de cisalhamento Paraíba do Sul (RJ) e Guaçuí (ES). in: I Simpósio Geologia do Sudeste, SBG/RJ, 120-121.

Collinson, D.W., 1983. Methods in palaeomagnetism techniques and instrumentation. NY, Chapman and Hall, 503 p.

Cordani, U.G., Melcher, G. C. \& Almeida, F.F.M, 1968. Outline of precambrian Geocronology of South America. Canadian Journal of Earth Sciences, 5: 629-632.

Cordani, U. G., Delhal, J. Gomes, C. B. \& Ledent, D., 1968b. Nota preliminar sobre idades radiométricas em rochas da região da Serra dos Orgãos e vizinhança leste de Minas Gerais e Espírito Santo. Boletim SBG/SP, 17: 89-92.

Cordani, U. G., 1968. Esboço da geocronologia Pré-Cambriana da América do Sul. Anais da Academia Brasileira de Ciências, 40: 47-51.

Cordani, U.G. \& Kawashita, K., 1971. Estudo geocronológico pelo método Rb-Sr de rochas graníticas intrusivas no grupo Açunguí. in: XXV Congresso Brasileiro de Geologia, SBG-SP, 24.

Cordani, U. G., Amaral, G. C. \& Kawashita, K., 1973. The precambrian evolution of South America. Sonderdruck aus der Geologischen Rundschau Band, F.E. Verlag, Stuttgart, 62: 309m317.

Cordani, U. G., Delhal, \& Ledent, D., 1973b. Orogenèses Superposèes dans le Précambrien du Brésil Sud Oriental. Revista Brasileira de Geociências SBG-SP, 3:1-22.

Cordani,U.G. \&Teixeira,W., 1979.Comentários sobre as determinações geocronológicas existentes para a região das folhas Rio de Janeiro, Vitória e Iguape, in Texto Explicativo da Carta do Brasil ao Milionésimo, DNPM/MME (Fonseca et.al., 1979) 175-207. 
Cordani, U.G. \& Brito Neves, B.B., 1982, The geologic evolution of South America during the Archean and Nearly Proterozoic. Revista Brasileira de Geociencias, 12: 78 88.

Cordani, U. G., Brito Neves, B. B., Fuck, R. A., Porto, R., Thomaz Filho, A., Cunha, F. M. B., 1984. Estudo preliminar de integração do Pré-Cambriano com os eventos tectônicos da bacias sedimentares brasileiras. in: Série Ciência - Técnica do Petróleo, Publicação 15. CENPES/ Petrobrás, RJ, 70 p.

Cordani,U.G. \& Teixeira,W., 1985. Estágio atual do conhecimento geocronológico de Minas Gerais. in:III Simpósio de Geologia de Minas Gerais, SBG/MG, 338-347.

Correa Neto, A. V., Dayan, H. I., Valença, J. G. \& Raphael Cabral, A. 1993. Geologia e estrutura da Zona de Cisalhamento do Rio Paraíba do Sul e adjacências, trecho entreTrês Rios e Sapucaia (RJ). in: III Simpósio Geologia Sudeste. SBG/RJ, 194-200.

Correa Neto, A.V. \& Dayan, H., 1994. Justaposição tectônica de rochas de niveis crustais distintos em faixas transpressivas: o caso da zona de cisalhamento do Rio Paraíba do Sul. in: XXXVIII Congresso Brasileiro de Geologia, SBG/SC, 1: 249-250.

Costa, L.A.M. \& Marchetto, C. M. L., 1978. Evolução textural dos granulitos de São Fidélis, RJ. in: XXX Congresso Brasileiro de Geologia, 3: 1250-1264.

Costa, A. G., Rosiere, C.A., Moreira, L.M. \& Fischel, D.P., 1995. Caracterização geotectônica do setor setentrional do Cinturão Ribeira: Evidência de acresção neoproterozóica no leste de MG, Brasil. Geonomos, 3:51-58.

Costa, A.G., 1997. Proposta de classificação litoestratigráfica para o leste de Minas Gerais. in: IX Simpósio de Geologia de Minas Gerais, SBG/MG Boletim 14: 40-41.

Costa, A. G., Rosiere, C.A., Moreira, L.M. \& Fischel, D.P., 1997b. Macroestruturação da região leste de Minas. in: VI Simpósio Nacional de Estudos Tectônicos, SBG/DF, 285287.

Costa, A.G., Rosiere, C.A., Ebert, H. D., Fuck, R.A. \& Pimentel, M.M., 1998. The relation between frontal and strike slip shear zones and the regional metamorphism and magmatism in deep crustal segment, northern Ribeira Belt, SE-Brasil. XIV International Conference on Basement Tectonics, UFOP/MG, Abstracts, 26-28.

Coward, M.P., 1976. Strain within ductile shear zones. Tectonophysics, 34: 181-197.

Coward, M. P. \& Potts, G.J., 1983. Complex strain patterns developed at the frontal and lateral tips to shear zones. Journal of structural geology, 5: 383-399.

Craig, J. R. \& Vaughan, D.J., 1994. Ore microscopy and ore petrography. John Wiley \& Sons, Inc.

Dayan, H. \& Keller, J.V., 1989. A Zona de Cisalhamento do Rio Paraíba do Sul nas vizinhanças de Três Rios. (RJ): uma análise da deformação por algumas feições estruturais. Revista Brasileira de Geociências, 19: 464-506. 
Dayan, H., Correa Neto, A. V. \& Valença, J. G., 1993. A Zona de Cisalhamento do Rio Paraíba do Sul: Estudo de padrões de orientação preferencial de eixos $C$ de quartzo. in: IV Simpósio Nacional de Estudos Tectônicos, SBG/MG, 12: 339-342.

Dehler, N.M., 1996. Análise geométrica e cinemática dos metassedimentos da klippe de ljaci, sul de Minas Gerais. Dissertação de Mestrado. IG-USP, 92 p.

Delhal, J., Ledent, D. \& Cordani, U. G., 1969. Ages Pb/U, Rb/Sr et K/Ar de formations metamorphiques et granitique du Sud-Est du Bresil etats de Rio de Janeiro e Minas Gerais. Annales Societte Geologique Belgique, 92: 271-283.

Duarte, B. P., Nogueira, J. R., Heilbron, M. \& Figueiredo, M. C. H., 1994. Geologia da região de Juiz de Fora e Matias Barbosa MG. in: XXXVIII Congresso Brasileiro de Geologia, SBG/SC, 88-90.

Duarte, B. P., M.C.H., F., Campos Neto, M. \& Heilbron, M., 1997. Geochemistry of granulite facies orthogneisses of the Juiz de Fora Complex, central segment of the Ribeira Belt, southeastern Brazil. Revista Brasileira de Geociências, 27: 67-82.

Dunlop, D.J. \& Ozdemir, O., 1997. Rock magnetism, fundamentals and frontiers. Ed. David Edwards, Cambridge Studies in magnetism Series, Cambridge University Press, Cambridge, UK, $573 p$.

Ebert, H., 1955. Pesquisas geológicas na parte sudeste do estado de Minas Gerais e Polígono das Secas. Relatório Anual da DGM/DNPM-RJ (1954), 79-89.

Ebert, H., 1956. Resumo dos resultados obtidos no ano de 1955 no Sul do estado de Minas Gerais. Relatório Anual da DGM/DNPM-RJ, 62-81.

Ebert, H., 1956b. A tectônica do sul do estado de Minas Gerais e regiōes adjacentes. Relatório Anual da DGM/DNPM-RJ (1956), 97-107.

Ebert, H., 1958. Discordâncias pré-cambrianas em Carandai, MG/RJ. Relatório Anual da DGM/DNPM-RJ (1957), 183-48.

Ebert, H., 1968. Ocorrências de fácies granulito no sul de Minas Gerais e em áreas adjacentes, em dependência da estrutura orogênica: hipótese sobre sua origem. Anais da Academia Brasileira de Ciências, 40: 215-229.

Ebert, H., 1971. Os Paraibides entre São João del Rey, MG e Itapira, SP, e a bifurcação entre Paraibides e Araxaides. in: XXV Congresso Brasileiro de Geologia, SBG/SP, 1: 177-178.

Ebert, H., 1984. Aspectos da geologia de São. João. Del Rey - os Paraibides entre São João Del Rey e Itapira e a bifurcação entre Paraibides e Araxaides. Publicação Especial SBG 12, 103p.

Ebert, H. D., Hasui, Y. \& Sena Costa, J.B., 1991. O carácter transpressivo do Cinturão Transcorrente do Rio Paraiba do Sul. in: Ill Simpósio Nacional de Estudos Tectônicos, SBG/SP, $139-141$. 
Ebert, H. D., Hasui, Y., Sartorato, G., Almeida, S.H. \& Costa, J.B.S., 1993. Arcabouço estrutural e tectônica transpressiva das faixas móveis das bordas sul e sudeste do Cráton do São Francisco e da Sintaxe de Guaxupé. in: VII Simpósio de Geologia de Minas Gerais, SBG/MG, 12: 166-171.

Ebert, H. D., Hasui, Y., Szatmari, P. \& Aires, J.R., 1993b. Evolução dos cinturões de cisalhamento entre os blocos de São Paulo, Vitória e Brasília, através de tectônica colisional oblíqua: uma modelagem física. in: IV Simpósio Nacional de Estudos Tectônicos, SBG/MG, 12: 254-258.

Ebert, H. D., Chemale Jr., F., Babinski, M. \& Van Schmus, W. R., 1994. Regimes tectônicos e idades U/Pb em zircão do Complexo Socorro no contexto da Faixa Ribeira um exemplo de magmatismo transpressivo. in: XXXVIII Congresso Brasileiro de Geologia. SBG/SC, 1: 260-261.

Ebert, H. D., Hasui, Y., 1998. Transpressional tectônics and strain partitioning during oblique collision between three plates in the precambrian of south-east Brazil. in: Holdsworth, Strachan \& Dewey. Continental Transpressional tectonics, Geological Society, London Special Publications, Blackwell, 135: 231-252.

Egydio Silva, M. \& Mainprice,D., 1999. Determination of stress directions from plagioclase fabrics in high grade deformed rocks (Além Paraíba Shear Zone), Ribeira fold belt, southeastern Brazil). Journal of Structural Geology, 21: 1751-1771.

Egydio Silva, M., Vauchez, A., Bascou, J. \& Hippert, J., 2002. High temperature deformation in the neoproterozoic transpressional Ribeira Belt, southeast Brazil. Tectonophysics. In press.

Ellwood, B. B. \& Whitney, J. A., 1980. Magnetic fabric of the Elberton Granite, Northeast Georgia. Journal of Geophysical Research, 85: 1481-1486.

Ellwood, B. B., Hrouda, F. \& Wagner, J.J., 1988. Symposia on magnetic fabrics: introdutory comments. Physics of the Earth and Planetary Interiors, 51: 249-252.

Endo, I. \& Machado, R., 1993. Sistema de Cisalhamento Atlântico: Um modelo tectônico transpressional para o Neoproterozóico do Brasil Oriental. in: IV Simpósio Nacional de Estudos Tectônicos, SBG/MG, 12: 356-359.

Endo, I. \& Machado, R., 1993b. Nova perspectiva de interpretação tectônica das faixas de dobramentos marginais ao Cráton do São Francisco. in:ll Simpósio do Cráton do São Francisco. SBG/BA, 283-285.

Figueiredo, M. C. H. \& Campos Neto, M. C., 1989. Geoquímica das rochas charnockíticas do norte do estado do Rio de Janeiro: transição da fácies anfibolito para a fácies granulito.

Figueiredo, M. C. H., Teixeira, W. \& Brito Neves, B. B., 1991. Gnaisses Mantiqueira, MG parte I: litogeoquimica. Anais da Academia Brasileira de Ciências, 64: 209-210.

Figueiredo, M. C. H. \& Campos Neto, M. C., 1993. Geochemistry of the Rio Doce Magmatic arc, SE-Brasil. Anais da Academia Brasileira de Ciências, 65: 63-81. 
Figueiredo, M. H. \& Teixeira, W., 1996. The Mantiqueira Metamorphic Complex, eastern MG. state preliminary geochronological and geochemical results. Anais da Academia Brasileira de Ciências, 68: 223-246.

Flinn, D., 1962. On folding during three dimensional progressive deformation. Journal Geological Society of London, 118: 385-428.

Flinn, D., 1979. The deformation matrix and the deformation ellipsoid. Journal of Structural Geology, 1: 299-307.

Fonseca, M. J. G., Silva, Z. C. G., Campos, D.A. \& Tosatto, P., 1979. Folhas Rio de Janeiro (SF-23), Vitória(SF-24) e Iguape(SG-23), Texto Explicativo e Carta do Brasil ao Milionésimo, DNPM/MME, 240p.

Fossen, H. \& Tikoff, B., 1993. The deformation matrix for simultaneous simple shearing, pure shearing and volume change, and its application to transpression transtension tectonics. Journal of Structural Geology, 15: 413-425.

Fossen, H., Tikoff, B. \& Teyssier, C., 1994. Strain modeling of transpression and transtension. Norsk Geologisk Tidsskrift, 74: 134-145.

Frost, B.R., 1991. Stability of oxide minerals in metamorphic rocks. Reviews in mineralogy, Mineralogical Society of America, $25469-487$.

Frost, B.R., 1991b. Magnetic petrology factors that control the occurrencce of magnetite in crustal rocks. Reviews in mineralogy, Mineralogical Society of America, 25 489-509.

Fuller, M., 1987. Experimental methods in rock magnetism and palaeomagnetism. Methods of experimental physics. Geophysics laboratory measurements, Part a edited by C.G. Sammis, T. L. H. Academic Press Inc., 24 303- 471.

Goodwin, P. \& Tikoff, B., 2002. Competency contrast, kinematics and the development of foliations and lineations on the crust. Journal of Structural Geology, 24:1065-1085.

Graham, J. W., 1954. Magnetic susceptibility anisotropy an unexploited petrofabric element. Geological Society of America Bulletin 65, 1257-1258.

Graham, S. A., 1983. Evolving concepts and teaching approaches in tectonic and sedimentation. Journal of Geological Education, 31: 266-276.

Harland, W. D., 1971. Tectonic transpression in Caledonian Spitsbergen. Geological Magazine, 108: 27-42.

Hasui, Y., Carneiro, C.D.R. \& Coimbra, A.M., 1975. The Ribeira Folded Belt. Revista Brasileira de Geociências, 5: 257-266.

Hasui, Y., Almeida, F. F. M. \& Brito Neves, 1978. As estruturas brasilianas. In: XXX Congresso Brasileiro de Geologia, Recife, PE, SBG-PE, 6: 2423-2437.

Hasui, $Y ., 1982$. The Mantiqueira Province: Archean structure and proterozoic evolution. Revista Brasileira de Geociências, 12: 167-172. 
Hasui, Y. \& Oliveira, M. A. F., 1984. Província Mantiqueira, setor central. 0 Precambriano do Brasil. Ed. Edgard Bluecher Ltda, SP, 308-344.

Heilbron, M., 1993. Evolução tectono metamórfica da Seção Bom Jardim de Minas, MG e Barra do Piraí, RJ no Setor Central da Faixa Ribeira. Tese de Doutoramento, IG-USP, $268 p$.

Heilbron, M., Rocha, A. D., Silva, L. G. E., Nogueira, J. R., Trouw, R. A. J., \& Polônia, J. A. L., 1994. Compartimentação tectônica da seção Conceição do Ibitipoca (MG) Valença, (RJ), segmento central da Faixa Ribeira. in: XXXVIII Congresso Brasileiro de Geologia, SBG/SC, 2:55-56.

Heibron, M. Valeriano, C. M., Almeida, J. C. H., Valladares, J. R. \& Tupinambá, M.. 1994b. Segmento central da Faixa Ribeira, exemplo de colisão continental oblíqua no Evento Termo-Tectônico Brasiliano. in: XXXVIII Congresso Brasileiro de Geologia, SBG/SC, 1:363-265.

Heilbron, M., Valeriano, C. M., Valladares, C. \& Machado, N., 1995. A orogênese brasiliana no segmento central da Faixa Ribeira, Brasil. Revista Brasileira de Geociências, 25(4): 249-266.

Heilbron, M., Figueiredo, M. C. H. \& Machado, R., 1997. Lithogeochemistry of paleoproterozoic orthogranulites from Rio Preto (MG) - Vassouras (RJ) region, central Ribeira Belt. Revista Brasileira de Geociências, 27(1): 83-99.

Heilbron, M., Tupinambá, M., Almeida, J. C. H., Valeriano, C. M., Valladares, C. \& Duarte, B. P., 1998. New constraints on the tectonic organization and structural styles related to the Brasiliano collage of the Central Segment of Ribeira Belt, SE, Brazil. International Conference on Precambrian and Craton Tectonics. Ouro Preto, Brazil, 1998, Resumos.

Heilbron, M., Mohriak, W., Valeriano, C. M., Milani, E. J., Almeida, J. C. H. \& Tupinambá, M., 1999. Ages of detrital zircon from central Ribeira Belt (Brazil) using Laser-ablation-ICPMS, in: II South American Symposium on Isotope Geology, Mendonza, Argentina.

Hrouda F., Janák F., Rejl L. \& Weiss J., 1971. The use of magnetic susceptibility anisotropy for estimating the ferromagnetic mineral fabrics of metamorphic rocks. Geologische Rundschau, 60: 1124-1142.

Hrouda, F. \& Janák, F., 1976. The changes in shape of the magnetic susceptibility ellipsoid during progressive metamorphism and deformation. Tectonophysiscs, 34: 135148.

Hrouda, F,, 1982. Magnetic anisotropy of rocks and its application in geology and geophysics. Journal of Geophysical Survey, 5: 37-82.

Hrouda, F., 1993. Theoretical models of magnetic anisotropy to strain relationship revisited. Physics Earth Planetary International, 77: 237-249. 
Ixler, R. A., 1990. Atlas of opaque and ore minerals and their associations. Prentice Hall. Inc. 203p.

Iyer, S. S., Choudhuri, A. \& Cordani, U. G., 1987. Granulite facies rocks of Brasil: a review of their geologic setting, Geocronological evolution, petrographic and geochemical characteristics. Journal Geological Society of India, 29: 309-326.

Jelinek, V., 1981. Characterization of the magnetic fabric of rocks. Tectonophysics, 79 : $63 m 67$.

Jelínek, $V ., 1984$. On a mixed quadratic invariant of the magnetic susceptibility tensor. Journal of Geophysics, 56: 58-60.

Jiang, D. \& Williamns, P. F., 1999. A fundamental problem with the kinematic interpretation of geological structures. Journal of Structural Geology, 21: $933-937$.

Junho, M. C. B., Toledo, C. L. B., Nogueira, J. R. \& Monsores, A. L. M., 1989. Geologia da região de Liberdade, Sul MG. in: I Simpósio Geologia do Sudeste, SBG/RJ, 155156.

Katz, M. B., 1972. The nomenclature of granulite facies rocks. N. Jahr. Mineralogische Monatschefte, 4: 152-159.

Lagoeiro, L.E., 1998. Transformation of magnetite to hematite and its influence on the dissolution of iron oxide minerals. Journal of Metamorphic Geology, 16: 415-423.

Lagoeiro, L.E, 1998b. Mecanismos de deformação e orientações cristalográficas preferenciais em tectonitos de formações ferríferas - quadrilátero ferrífero, MG. Tese de Doutoramento, IG - USP, $160 \mathrm{p}$.

Lagroix, F., Borradaile, G. J., 2000. Magnetic fabric interpretation complicated by inclusions in mafic silicates. Tectonopphysics, 325: 207-225.

Lamego, A. R., 1938. O Maciço do Itatiaia e regiões circundantes. Boletim do Serviço Geológico de Mineração (1936), SGM/DNPM, 88: 1-93.

Machado, R., 1984. Evolução geológica metamórfica e estrutural da região de Vassouras e Paracambi, porção ocidental do estado do Rio de Janeiro. Tese de Doutoramento, IG-USP.

Machado, R., 1986. Considerações preliminares sobre a aplicação de um modelo tectônico para os complexos Serra dos Órgãos e Paraíba do Sul (RJ): um possível exemplo de colisão continental. in: XXXIV Congreso Brasileiro de Geologia, SBG/GO, $135-136$.

Machado, R., Demange, M., Pellogia, A.U. \& Monteiro, R.L., 1989. Rochas graníticas e charnockiticas do estado do Rio de Janeiro: Associações petrográficas e suas relações com os domínios estruturais. . in: I Simpósio Geologia Sudeste. SBG/RJ, 151-152. 
Machado, R. \& Endo, I., 1993. Cinturão de Cisalhamento Atlântico: Um exemplo de tectônica transpressional neoproterozóica. in: IV Simpósio Nacional de Estudos Tectônicos, SBG/MG, 12: 189-191.

Machado, R., Endo, I., 1993b. A mega estrutura em flor positiva do Vale do Rio Paraíba do Sul no Rio de Janeiro e suas implicações tectônicas regionais. in: III Simpósio Geologia Sudeste. SBG/SP, 208-213.

Machado, R. \& Demange, M., 1994. Classificação estrutural e tectônica dos granitóides neoproterozóicos do Cinturão Paraíba do Sul no estado do Rio de Janeiro. Boletim IGUSP, Série Científica, 25:81-96.

Machado, R. \& Endo, I., 1994. Superposição cinemática brasiliana no Cinturão de Cisalhamento Atlântico e na Cunha de Guaxupé. in: XXXVIII Congresso Brasileiro Geologia. SBG/SC, 1: 269-271.

Machado, R., 1997. Litogeoquímica e tectônica dos granitóides neoproterozóicos do Cinturão Paraíba do Sul no estado do Rio de Janeiro. Tese de Livre Docência, IG-USP, $215 p$.

Machado, R., Demange, M., McReath, I. \& Moutte, J,, 2000. Crustal zoning of neoproterozoic pre-collisional granitoids in the Paraiba do Sul Belt, Rio de Janeiro, Brasil. Revista Brasileira de Geociências, 30: 70-73.

Machado Fitho, I, Ribeiro, M. W., Gonzalez, S. R., Schenini, C. A., Santos Neto, A., Palmeira, R. C. B., Pires, J. L., Teixeira, W. \& Castro, H. E. F., 1983. Folhas SF-23/24, Rio de Janeiro/Vitória. Mapa e Geologia (32), Projeto RadamBrasil, MME, 775p.

Machado, N., Valladares, C. S., Heilbron, M. \& Valeriano, C., 1996. U-Pb geochronology of the Central Ribeira Belt Brazil and implications for the evolution of the brazilian orogeny. Precambrian Research, 79: 347-362.

Nagata, T., 1961. Rock Magnetism. Maruzen Pub. Ltd. Tokio, 350p.

Nicolas, A., 1987. Principles of rock deformation. Reidel Publishers \& Co., Dordrecht., $208 \mathrm{p}$.

Nicolas, A., Bouchez, J.L., Blaise, J. \& Poirier, J.P., 1977. Geological aspects of deformation in continental shear zones. Tectonophysics, 42: 55-73.

Nieto- Samaniego, A. F., 1999. Stress, strain and fault patterns. Journal of Structural Geology, 21: 1065-1070.

Nogueira, J. R. \& Trouw, R. A. J., 1993. Mapeamento geológico, 1:50.000, estruturas e metamorfismo de uma região a SW de Juiz de Fora, MG. in: III Simpósio Geologia Sudeste. SBG/SP, 180-186.

Nogueira, J. R., 1994. Relações tectonoestruturais e metamórficas entre metassedimentos e ortognaisses em fácies granulito na região a SW de Juiz de Fora, MG. Tese de Mestrado, UFRJ. 
Oliveira, M. A. F., 1980. Petrologia das rochas granulíticas da Faixa Paraiba do Sul, Rio de Janeiro e Minas Gerais. Tese de Livre Docência, IGCE/UNESP, 116p.

Oliveira, M.A.F. , 1981. Granulitos da Faixa Paraíba do Sul: caracteres geoquímicos dos piroxênios e valores geotermobarométricos. Revista Brasileira de Geociências, 11: 273-292.

Oliveira, M. A. F., 1982. Bulk geochemistry of the Paraiba do Sul Granulitic Belt. Boletim SBG, 12: 369-374.

Oliveira, M. A. F., 1983. As rochas granulíticas da Faixa Paraíba do Sul. Revista Brasileira de Geociências, 13(2): 84-902.

Oliveira, M. A. F., Tupinambá, M., Heilbron, M. \& Kawashita, K., 1999. Rb/Sr isochronic ages of a palaeoproterozoic orthognaiss (Quirino Unit) from the Central Ribeira Belt, Southeastern Brazil. in: II South American Symposium on Isotope Geology, Mendonza, Argentina, 54-56.

Passchier, C. \& Simpson, C., 1987. Porfiroclast systems as kinematic indicators. Journal of Structural Geology, 8; 831-843.

Passchier, C. \& Trouw, R., 1997. Microtectonics. Springer, Berlim, $289 p$.

Passchier, C., 1997. The fabric attractor. Journal of Structural Geology, 19: 113-127.

Paterson, S. R., Vernon, R. \& Tobish, O. T., 1989. A review of criteria for the determination of magmatic and tectonic foliations in granitoids. Journal of Structural Geology, 11: 349-363.

Peckett, A., 1992. The colours of opaque minerals. John Wiley \& Sons, NY, USA, 471 p.

Philpotts, A. R., 1989. Petrography of Igneous and Metamorphic Rocks. Prentice Hall Inc., $175 p$.

Pinto, C. P. \& Padilha, A. V., 1993. Esboço de integração geológica regional e evolução tectônica para parte do SE do Brasil. in: VII Simpósio de Geologia de Minas Gerais, SBG/MG, 12: 65-68.

Porcher, C., 1997. Relações entre Metamorfismo e Deformação na Faixa Ribeira: Regiões de Três Rios e Santo Antônio de Pádua (RJ). Tese de Doutoramento, IGUFRGS, 241p. (inédito)

Ramdhor, P., 1980. The ore minerals and their intergrows. Pergamon Press, Oxford, UK.

Ramsay, J. G, 1980. Shear zone geometry: A Review.Journal of Structural Geology, 2: 83-100. 63: 512-526.

Ramsay, J. G. \& Huber, M.I., 1997. The techniques of modern structural geology. Strain Analysis \& Folds and fractures. Hartcourt Brace Co. Publishers. Academic Press, San Diego. 307 p. 
Raposo, M. \& Egydio-Silva, M., 2001. Magnetic fabric studies of high-grade metamorphic rocks from the Juiz de Fora Complex, Ribeira Belt, Southeastern Brazil. International Geology Review, 43:441, 456.

Ribeiro, A., Andreis, R. R., Paciullo, F. V. P., Trouw, R. A. J. \& Heilbron, M., 1990. Evolução policíclica proterozóica no sul do Cráton de São Francisco: análise da região de São João Del Rei e Andrelândia, Minas Gerais, in: XXXVI Congresso Brasileiro Geologia, SBG/RN, Natal, 6: 2605- 2614.

Ribeiro, A., Andreis, R. R., Trouw, R. A. J., Paciullo, F. V. P. \& Valença, J.G., 1995. Evolução das bacias proterozóicas e termotectonismo brasiliano na margem sul do Cráton do São Francisco. Revista Brasileira de Geociências, 25: 235-248.

Rochette, P., Aubourg, C. \& Perrin, M., 1999. Is this magnetic fabric normal? A review and case studies in volcanic formations. Tectonophysics, 307: 219-234.

Rosier, G. F., 1957. A geologia da Serra do Mar entre os Picos de Maria Comprida e do Desengano, RJ. Boletim do DGM/DNPM-RJ, 166, 58p.

Rosier, G. F., 1965. Pesquisas geológicas na parte oriental do estado do Rio de Janeiro e na parte vizinha do estado de Minas Gerais. Boletim do DGM/DNPM, 222, 41p.

Ruf, A., Naruk, S. J., Butler, R. F. \& Calderone, G. J., 1988. Strain and magnetic fabric in the Santa Catalina and Pinaleno Mountains Metamorphic Core Complex mylonite zones, Arizona. Tectonics, 2: 235-248.

Sadowski, G. R., 1991. Geologia estrutural de Cinturões de Cizalhamento Continentais. Tese de Livre Docência, IG - USP, 108p.

Sanderson, D. \& Marchini, R. D., 1984. Transpression. Journal of Structural Geology, 6 : 449-458.

Shive, P.N. \& Fountain, D.M., 1988. Magnetic mineralogy in an Archaean crustal cross section: implications for crustal magnetization. Journal of Geophysical Research, 93: $12177-12186$.

Siga Jr., O., Teixeira, W., Cordani, U. G., Kawashita, K. \& Delhal, J., 1982. Padrão geológico-geocronológico das rochas de alto grau da parte setentrional da Faixa Ribeira. in: V Congresso Latino-amenricano de Geologia, Buenos Aires, 1: 349-370.

Siga Jr., O., Tassinari, C.C.G. \& Van Schmus, W. R., 1989. Caracterização geocronológica dos maciços charnockíticos do sudeste brasileiro. in: I Simpósio de Geologia do Sudeste, SBG/RJ, 90-91.

Silva, R. R., Junho, M. C. B., Monsores, A. L. M., Nogueira, J. R. \& Alves, M. J. S., 1992. Geologia do Grupo Andrelândia na região de Aiuruoca - Liberdade, MG. in: VI Simpósio Geologia de Minas Gerais, SBG/MG, Ouro Preto, MG.

Simpson, C. \& Schmid, S.M., 1983. An evaluation of criteria to deduce the sense of movement in sheared rocks. Geological Society of America Bulletin, 94: 1281-1288. 
Söllner, F., Lammerer, B. \& Weber-Diefenbach, K, 1991. Die Krustenentwicklung in der Kusternregion nördlich von Rio de Janeiro, Brasilien. Munchner Geologische Hefte 4 , München, 100p., apud Machado et al., 1996.

Stacey, F. D., 1960. Magnetic anisotropy in igneous rock. Journal of Geophysical Research, 65: 2429-2442

Steinsund, P., I., 1991. StereoNet for Windows, version 3.01, Copyright (1991-1995) Per Ivar Steinsund, University of Tromso, Norway.

Strieder, A. J., 1993. Tectônica colisional no Brasil Central: evolução e implicações no padrão estrutural. in: IV Simpósio Nacioanl de Estudos Tectônicos, SBG/MG, 12: 297301.

Streckeisen, A. L., 1974. Classification and nomenclature of plutonic rocks, recommended by IUGS subcommission on the sistematics of igneous rocks. Geologische Rundschau Internationale Zëitschrift für Geologie, Sttutgart, 63: 773 785.

Streckeisen, A. L., 1975. How should charnockitic rocks be named? Centenenial Geological Society Belgica, Liege, 349-360.

Streckeisen, A. L., 1976. To each plutonic rock its proper name. Earth Science Reviews, 12: 1-33.

Tarling, D.H. \& Hrouda, F., 1993. The magnetic anisotropy of rocks. Chapman \& Hall, London, $217 p$.

Teixeira, W. \& Figueiredo, M. C. H., 1991. An outline of early proterozoic crustal evolution in the São Francisco Craton, Brazil, Review. Precambrian Research, 53: 1-22.

Teyssier, C. \& Tikoff, B., 1999. Fabric stability in oblique convergence and divergence. Journal of Structural Geology, 21: 969-974.

Tikoff, B. \& Teyssier, C., 1994. Strain modeling of displacement field partitioning in transpressional orogens. Journal of Structural Geology, 16: 1575-1588.

Tikoff, B. \& Wojtal, S. F., 1999. Displacement control of geologic structures. Journal of Structural Geology, 21: 959-967.

Tommasi, A., 1991. Evolução cinemática do Cinturão Dom Feliciano. Dissertação de Mestrado, Orientador: Luiz Alberto D'Avila Fernandes, IG - UFRGS, 234p.

Trompette, R., Egydio-Silva, M., Tommasi, A., Vauchez, A. \& Uhlein, A., 1993. Amalgamação do Continente Gondwana no Pan-Africano Brasiliano e o papel da geometria do CSF na arquitetura da Faixa Ribeira. Revista Brasileira de Geociências, 23: $187-193$.

Trouw, R. A. J., Ribeiro, A. \& Paciullo, F. V. P., 1980. Evolução estrutural e metamórfica de uma área a SE de Lavras, MG. in: XXXI Congresso Brasileiro Geologia, SBG/SC, 5 : 2273-2284. 
Trouw, R. A. J., Ribeiro, A., Paciullo, F. V. P., Chrispin, S. J. \& Dayan, H., 1982. Análise da deformação numa área a SE de Lavras, MG. in: XXXII Congresso Brasileiro Geologia, SBG/Ba, Salvador, 1: 187-196.

Trouw, R. A. J., 1992. Evolução tectônica ao sul do Cráton de São Francisco baseada em análise metamórfica. in: XXXVII Congresso Brasileiro Geologia, SBG/SP, :327 -328.

Trouw, R. A. J. \& Pankhurst, K. J., 1993. Idades radiometricas do sul do Cráton de SãoFrancisco região da folha Barbacena, Minas Gerais. in: II Simpósio sobre o Cráton do São Francisco e suas Faixas Marginais. SBG/BA-SE, BA, 260-262.

Trouw, R. A. J., Paciullo, F. V. P. \& Ribeiro, A., 1994. A Faixa Alto Rio Grande reinterpretada como zona de interferência entre a Faixa Brasilia e a Faixa Ribeira. in: XXXVII Congresso Brasileiro de Geologia SBG/SC, 1:234-235.

Tupinambá, M. S., 1993. Litoestratigrafia, estruturas e metamorfismo pré-cambriano entre Itaperuna e ltalva - RJ. Dissertação de Mestrado. PPG/UFRG, RJ, $163 p$.

Tupinambá, M. S., 1993b. Metamorfismo granulítico do Complexo Paraíba do Sul na parte setentrional da Faixa Ribeira, a leste do Cráton do São Francisco. in: II Simpósio sobre o Cráton do São Francisco e suas Faixas Marginais. SBG/BA-SE, BA, 284-286.

Tupinambá, M. S., 1993c. Rochas intrusivas e metassedimentos granulíticos do Grupo Paraíba do Sul na parte setentrional da Faixa Ribeira. in: II Simpósio de Geologia do Sudeste, SBG/RJ, 187-191.

Tupinambá, M. S., 1999. Evolução tectônica e magmática da Faixa Ribeira na região serrana do estado do Rio de Janeiro. Tese de Doutoramento. IG-USP, 196 p.

Uyeda, S., Fuller, M. D., Belshe, J. C. \& Girdle, R. W., 1963. Anisotropy of magnetic susceptibility of rocks and minerals. Journal of Geophysical Research, 68 : 279-291.

Valladares, C. S., Heilbron, M., Figueiredo, M. C. H. \& Teixeira, W., 1997. Geochemistry and geochronology of paleoproterozoic gneissic rocks of the Paraiba do Sul Complex Quirino Unit, Barra Mansa Region, Rio dejaneiro, Brazil. Revista Brasileira Geociências., 27: 111-120.

Valladares, C. Heilbron, M., Machado, N. \& Valeriano, C., 1997b. Provenance of central Ribeira belt metasediments using ${ }^{20 /} \mathrm{P} / 206 \mathrm{P}$ ages on zircon by laser-ablation ICPMS. I South American Symposium on Isotope Geology, Brazil, 323-325.

Vauchez, A., 1987. Mecanismes de deformation et cinematique des zones de mouvement ductiles. Tese de Doutoramento. Faculte de Sciences et Techniques de Saint Jérome, France. $315 \mathrm{p}$.

Vauchez, A., Tommasi, A., Egydio-Silva,M. \& Trompette, R., 1992. Tectônica de escape na terminação de um cráton: A Faixa Ribeira. in: XXXVII Congresso Brasileiro de Geologia, SBG/SP, 2: 373-375.

Vauchez, A., Tommasi, A. \& Egydio-Silva, M., 1994. Self-indentation of a heterogeneous continental lithosphere. Geology, 22: 967-970. 
Vauchez, A., Tommasi, A. \& Barruol, G., 1998. Rheological heterogeneity, mechanical anisotropy and deformation of the continental lithosphere. Tectonophysics, 296: 61-86.

Waychunas, G.A., 1991. Crystal chemistry of oxides and oxihydroxides. Reviews in mineralogy, Mineralogical Society of America, 25: 11-68.

Wernick, E., Hasui, Y. \& Brito Neves, B. B., 1978. As regiões de dobramento Sudeste e Nordeste. In: XXX Congresso Brasileiro de Geologia, SBG/PE. 6: 2493-2507.

Wernick, E., 1979. O magmatismo granitóide das regiões de dobramento do nordeste e sudeste do Brasil. Revista Brasileira de Geociências, 9: 122-139.

Williams, M.C., Shive, P.N., Fountain, D.M. \& Frost, B.R., 1986. Magnetitc properties of exposed deep crustal rocks from the Superior Province of Manitoba. Earth and Planetary Science Letters, 76: $176-184$.

Winge, M., 1995. Evolução dos terrenos granulíticos da Provincia estrutural Tocantins, Brasil Central. Tese de Doutoramento, IG-UNB, 140p.

Winkler, H.G.F., 1977. Petrogênese de Rochas Metamórficas Porto Alegre, Editora da UFRGS, $245 p$. 


\section{A.1. Síntese bibliográfica regional}

Lamego $(1936,1938$ ) (apud Dehler, 1996) reconheceu a dobra sinclinal do Vale do Paraíba do Sul, descrevendo a Serra do Mar como estruturada em dobramento monoclinal, com áreas muito deformadas.

Ebert (1955, 1956, 1956b, 1957, 1958, 1968, 1971, 1984) (apud Dehler, 1996), definiu a Série Juiz de Fora, depois enquadrada no Grupo Paraíba do Sul, metamorfizada na fácies granulito e composta de granulitos paraderivados e charnockitos. Definiu a Série Paraibuna, modificada para Série Paraíba e depois para Grupo Paraíba (1967) composto de grauvacas, quartzitos e gnaisses metamorfizados na fácies anfibolito a granulito. Segundo este autor, a vergência estrutural seria em direção ao Cráton do São Francisco, na região mais próxima a Minas Gerais e oposta a este cráton na região a leste do Rio Paraíba.

Ebert (op.cit.) definiu a Faixa Paraíba (1968) como um longo cinturão orogênico ao longo da costa oriental do Brasil, desde o Sul da Bahia ao Rio Grande do Sul e Uruguai, com evidências de tectônica de empurrão e mais tarde (1971) propôs que a Série Andrelândia gradacionaria para a Série Paraíba, considerando o aumento do grau metamórfico. Denominou as faixas orogenéticas que se bifurcam a partir da extremidade sul do Cráton do São Francisco como Faixa Araxaides e Faixa Paraibides, esta última situada a nordeste do cráton, paralela à costa.

Rosier $(1955,1957,1965)$ (apud Tupinambá, 1999) propôs a Série do Paraíba e Nappe do Desengano, que depois renomeou como Série Paraíba-Desengano, de idade pré-cambriana e arqueana, composta de gnaisses, migmatitos, charnockitos e quartzitos, separados pelo grau metamórfico em unidade inferior, de catazona e superior, de mesozona, estruturadas por tectônica de nappes e diáclases, advinda da orogênese assíntica com falhas e diáclases pós-assínticas.

A Série Paraíba-Desengano seria composta por nappes transportadas de sudeste para noroeste, que comporiam o geossinclinal assíntico, tendo como front as litologias da zona de falhamentos do Rio Paraíba do Sul e como cobertura às rochas da Faixa Paraíba. Esta estruturação seria responsável pela inversão metamórfica ali observada.

Posteriormente este autor abandonou sua proposta de tectônica de nappes e propôs que esta faixa geossinclinal, representada pelos metassedimentos da orogênese assíntica, estaria dividida em estruturas distintas: o antepaís da orogênese assíntica, a faixa geossinclinal da orogênese, que seria a Série Paraíba-Desengano e, o embasamento préassíntico, remobilizado durante a orogênese assíntica, que seria a Série Serra dos Órgãos. 
Almeida $(1967,1969,1971)$ definiu a "Plataforma Brasileira" como uma antiga ortoplataforma, consolidada no Ciclo Baikaliano, Neogeno, sendo uma de suas faixas marginais a "Faixa Paraíba", sin-baikaliana, com vergência para o Cráton do São Francisco.

Grossi Sad \& Ladeira (1968) renomearam a Faixa Paraíba de Ebert (op. cit.) como Cinturão Orogênico Atlantides.

Cordani (1968) e Cordani et al. (1968, 1968b, 1971) verificaram idades $\mathrm{Rb} / \mathrm{Sr}$ em rocha total de 600 M.a. para as rochas da Faixa Paraíba e idades $\mathrm{Rb} / \mathrm{Sr}$ e K/Ar em minerais (mica e anfibólio) de 470 M.a. para as mesmas rochas. Colocaram que as Séries Paraíba e Juiz de Fora de Ebert, constituídas por rochas metassedimentares, teriam sido geradas no Ciclo Transamazônico, há 2,0 G.a. e metamorfizadas na fácies granulito e anfibolito em ambiente de catazona.

Segundo Cordani e colaboradores estas rochas foram afetadas por um evento tectônico posterior, há 500-600 M.a. (incluindo dataçöes K/Ar em rochas da região de Santo Antônio de Pádua, área desta dissertação), que produziu deformação paralela ao bandamento metamórfico regional.

Os autores separaram, dentro da Faixa Paraíba, as formações Serra dos Órgãos e Paraíba, denominando a Faixa Paraíba de Cinturão Paraíba (1971) e posteriormente de Cinturão Orogenético Ribeira, sin-brasiliano, com extensão ao longo da costa sudeste do Brasil e Uruguai, possuindo embasamento ensiálico, com indicação de reativação de antigas regiões cratônicas, sem acresção continental no fim do Pré-Cambriano.

Delhal et al. (1969) através dos métodos $\mathrm{K} / \mathrm{Ar}, \mathrm{Rb} / \mathrm{Sr}$ e U/Pb, dataram os gnaisses migmatíticos do sudeste em 2,0 G.a., Ciclo Transamazônico e dataram o metamorfismo dos gnaisses dos complexos Paraíba do Sul e Juiz de Fora e das rochas granitóides da Serras dos Órgãos, em 620 M.a., Ciclo Brasiliano, obtendo razão inicial Sr87/Sr86 de 0,710 para o Complexo Paraíba do Sul, considerada elevada para rochas primárias do Ciclo Transamazônico e, compatível com retrabalhamento de rochas mais antigas.

Cordani, Amaral \& Kawashita (1973) e Cordani et al. (1973b) descreveram o cinturão orogênico Ribeira, constituído de rochas metamórficas variando da fácies xistos verdes até a fácies anfibolito, disposto ao longo da costa atlântica do Brasil, desde a Bahia até o Uruguai, com trends estruturais paralelos à costa e com padrão geocronológico similar ao Cinturão Caririano (disposto ao longo da borda N-NE do Cráton São Francisco).

As rochas deste cinturão Ribeira teriam idades tranzamazônicas e rejuvenescimento em orogênese neoproterozóica. 
Para Cordani et al. (op.cit.), a Faixa Paraíba, região de ocorrência dos Complexos Juiz de Fora e Paraíba do Sul, estaria inserida geologicamente num cinturão complexo de dobramentos e empurrões, gerado no Neoproterozóico, durante o Ciclo Brasiliano, a sulsudeste do Cráton do São Francisco.

Através de datações radiométricas $\mathrm{K} / \mathrm{Ar}, \mathrm{Rb} / \mathrm{Sr}$ e U/Pb obtiveram, para o Gnaisse Mantiqueira, idade de 2,8 G.a. e para as rochas do Complexo Juiz de Fora e Grupo Paraíba do Sul, idades de 2,070 e 1,983 G.a. O metamorfismo na fácies granulito a anfibolito teria ocorrido num evento anterior a milonitização. Dois eventos que geraram granitos foram observados, um primeiro, sin - Brasiliano, ocorrido há 620 - 540 M.a. e outro evento, tardi a pós-brasiliano, ocorrido há 500 - 470 e 450 M.a. (vide fig.A.1.)

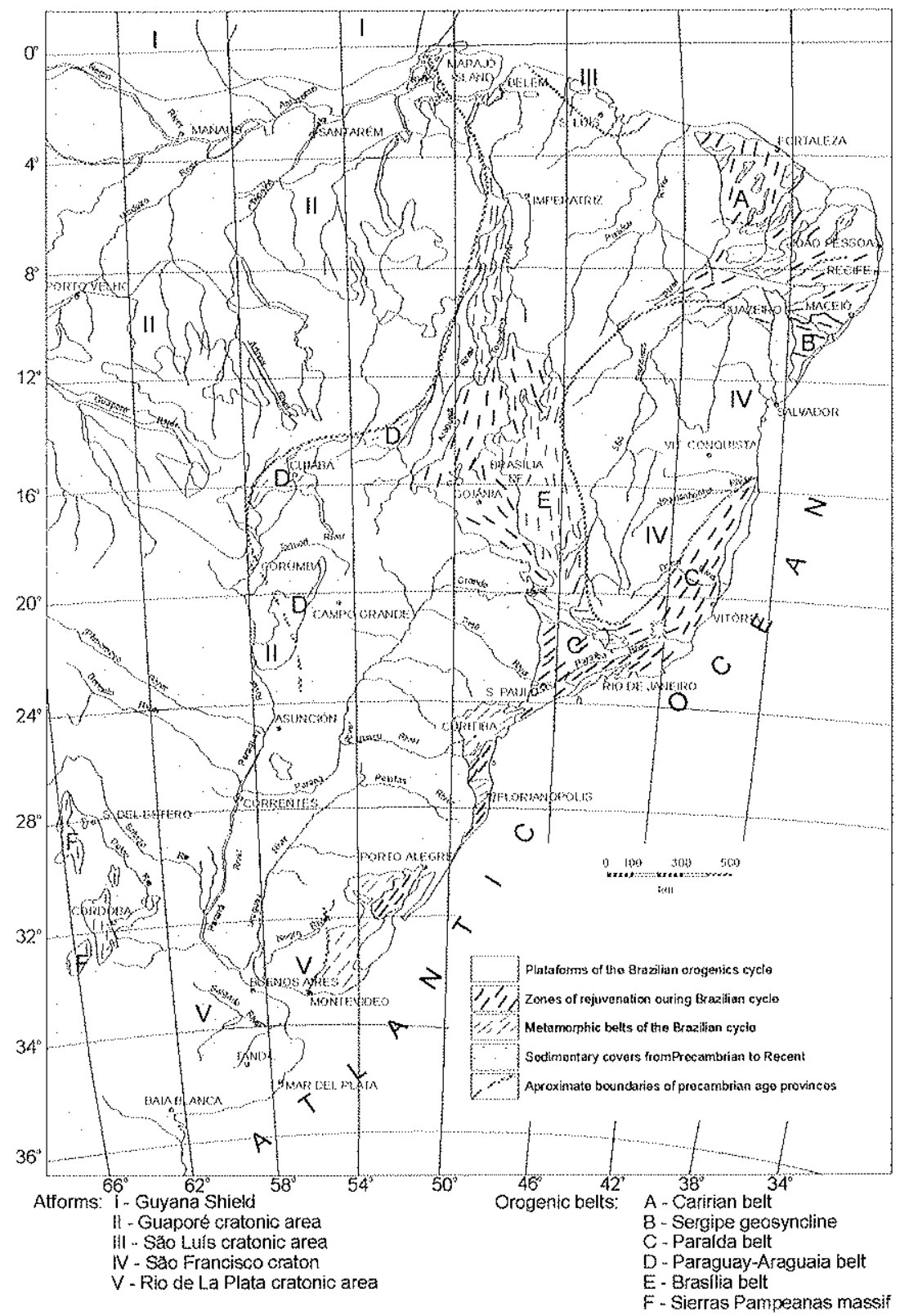

Fig. A.1.: Principais unidades geotectônicas do Brasil segundo Cordani et al., 1973. 
Almeida et al. $(1973,1975,1976 b)$ definiram o "Cinturão Ribeira" como uma unidade tectônica de idade brasiliana que seria a responsável pelo retrabalhamento da área representada pela Série Serra dos Órgãos de Rosier (op. cit.) e que estaria sobreposta a uma unidade com idade transamazônica, o Cinturão Paraíba do Sul representado pela Série Paraíba - Desengano de Ebert e Rosier (op.cit. ).

Neste trabalho o Cinturão Ribeira foi definido compreendendo uma área entre o Sul da Bahia e o sudeste do Uruguai. Mais tarde (1976) os autores definiram o "Lineamento Além Paraíba", caracterizado pelo curso retilineo do Rio Paraíba do Sul entre Andrade Pinto e Itaocara, com extensão de $150 \mathrm{~km}$ de rochas miloníticas. Esta estrutura consistiria de uma falha transcorrente de rejeito direcional e sentido dextrógiro, ao longo do curso do Rio Paraíba do Sul, até sua quebra para sudeste.

Hasui et al. $(1975,1978)$ identificaram uma compartimentação tectônica diferenciada na costa sudeste brasileira, parte com direção transversal e parte longitudinal, dividindo a Faixa Paraíba em dois setores, meridional e setentrional, separados pela zona de transcorrência São Paulo.

Os autores propuseram o Cinturão Ribeira, com extensão ao longo da margem atlântica meridional do Brasil. Posteriormente (1978) analisando as estruturas brasilianas da Província Mantiqueira através de semelhanças petrológicas e estruturais e de dados geogronológicos, subdividiram esta província em sub-província Serra do Mar (Região de Dobramentos Sudeste) e sub-província do Rio Doce (Faixa de Dobramentos Paraíba do Sul), estendendo o Grupo Paraíba do Sul aos estados de São Paulo e Minas Gerais.

Brandalise et al. (1976, apud Brenner et al., 1980) identificaram grandes falhas de extensão regional na região sudeste, através de imagens de radar, caracterizadas pela presença de faixas de rochas cataclásticas pré-cambrianas. Específicamente na área deste estudo, estes autores definiram a falha do Rio Paraíba do Sul médio e inferior, que engloba todos os lineamentos do domínio gnáissico, ao norte do Rio Paraíba, até a dobra deste rio para Sudeste, abrangendo o Lineamento Além Paraíba (Almeida et al., op. cit.).

Renomearam a Série Paraíba-Desengano de Rosier (op. cit.) como Complexo Paraíba do Sul.

Almeida (1976, 1977, 1981) propôs a compartimentação tectônica do Brasil em províncias estruturais, onde ao sul do Cráton do São Francisco seria o contato da Província Tocantins, faixas de dobramentos Uruaçu e Brasília, com a Província Mantiqueira, disposta ao longo da costa atlântica, do sul do paralelo $15^{\circ}$ até a fronteira com Uruguai, na margem do Cráton do São Francisco. 
O Cinturão Paraíba do Sul (transamazônico) e o Cinturão Ribeira (brasiliano) estariam inseridos no contexto da Província Mantiqueira e o Cinturão Ribeira seria o limite noroeste do Cráton do Rio de La Plata.

Costa \& Marchetto (1978) estudando as rochas a norte e noroeste do Rio de Janeiro colocaram que as unidades que ali ocorrem seriam correlacionadas às litologias do Complexo Paraíba do Sul, e propuseram um modelo de evolução textural das rochas granulíticas e charnockíticas do Grupo Paraíba do Sul, creditando idade tranzamazônica para os granulitos da área.

A Unidade São Joaquim seria composta de mármores, rochas calciossilicáticas e anfibolitos; a Unidade São Fidélis seria composta de granada gnaisses kinzigíticos; a Unidade Santo Eduardo compreenderia gnaisses migmatíticos bandados, anfibolitos e quartzitos; a Unidade Italva seria composta de biotita gnaisses tonalíticos e a Unidade Angelim de gnaisses tonalíticos homogêneos.

Estes autores consideraram origem plutônica e magmática/migmatítica para os charnockitos que ali ocorrem e, para os granulitos a origem seria pela cataclase e recristalização posterior dos tipos charnockíticos, após passarem por termos miloníticos. Consideraram também que uma fase de deformação mais jovem gerou cataclase, suplantando a recristalização.

Durante a primeira fase de deformação teria atuado um metamorfismo dinâmico, regional, havendo predominância da recristalização sobre a cataclase, quando se formaram milonitos e gnaisses miloníticos, com textura predominante granoblástica e inequigranular, pela presença frequente de porfiroclastos ainda não recristalizados.

Wernick et al. $(1978,1979)$ denominou a Faixa Paraíba de Região de Dobramentos Sudeste, cuja evolução tectônica teria seguido a teoria geossinclinal, durante o Ciclo Transamazônico. Posteriormente (1979) definiram o Cinturäo Granulítico Atlântico subdividido nos complexos Caraiba, Jequié, Salvador e Paraíba. O Complexo Paraíba apresentaria ocorrências descontínuas de granulitos intercaladas com gnaisses num embasamento mais antigo, remobilizado durante o Ciclo Brasiliano e, as litologias deste complexo foram agrupadas na "Associação Paraíba do Sul" subdividida em Complexo Migmatítico e Complexo Charnockítico.

Fonseca et al. (1979) englobou no Complexo Juiz de Fora as rochas de associação charnockítica, migmatitos e gnaisses facoidais, de idade pré-cambriana ou mais antigos, 2,5 a 1,8 G.a. e no Grupo Paraiba do Sul as rochas do Vale do Paraíba do Sul, gnaisses granitóides, plagioclásio - biotita - hornblenda gnaisses com termos granitóides, migmatitos 
e lentes de anfibolitos, rochas carbonáticas, xistos e quartzitos, de idade pré-cambriana superior, 1 G.a. a 570 M.a..

Hasui et al. $(1979,1981)$ e Hasui (1982) propõem o Complexo Paraíba do Sul, composto por gnaisses, migmatitos, intercalados com mármores, calciossilicáticas e metabasitos, representaria a associação de rochas supracrustais gerada no Proterozóico Inferior, dispostas sobre embasamento de idade arqueana.

As rochas deste Complexo teriam sofrido metamorfismo regional, deformação e milonitização durante o Ciclo Tranzamazônico, com retrabalhamento durante um evento transcorrente de idade brasiliana, ou seja, parte deste complexo representaria terrenos granito-gnáissicos arqueanos, reativados no Ciclo Brasiliano.

Cordani \& Teixeira (1979) realizaram um levantamento dos dados radiométricos $\mathrm{Rb} / \mathrm{Sr}, \mathrm{K} / \mathrm{Ar}$ e U/Pb existentes para a região compreendida pelas folhas Rio de Janeiro, Vitória e lguape reavaliando os dados existentes. As rochas da Faixa Ribeira, de idades tranzamazônicas, foram rejuvenescidas durante o Ciclo Brasiliano, segundo datações em $\mathrm{K} / \mathrm{Ar}$ e isócronas minerais $\mathrm{Rb} / \mathrm{Sr}$.

Segundo os autores, as rochas do Complexo Paraíba do Sul (N.A.: cujo complexo charnockítico ali referido está englobado no Complexo Juiz de Fora, nesta dissertação) forneceram idades de 2.0 G.a. (U/Pb diagrama concórdia), interpretadas como a época do metamorfismo catazonal. Um evento mais jovem teria ocorrido há 620 M.a., correspondente à granitização brasiliana.

As idades isocrônicas $\mathrm{Rb} / \mathrm{Sr}$ mostraram dados similares e a razão inicial $\mathrm{Sr}^{87} / \mathrm{Sr}^{86}$ de 0,709 sugeriu natureza ensiálica para os protólitos destas rochas.

As rochas granuliticas da Faixa Ribeira, (granulitos de São Fidélis) apresentaram idade isocrônica $\mathrm{Rb} / \mathrm{Sr}$ de $600 \mathrm{M}$.a., formadas provavelmente durante o metamorfismo brasiliano ocorrido em níveis crustais profundos desta região.

Na região de Juiz de Fora foi obtida idade $\mathrm{Rb} / \mathrm{Sr}$ em rocha total de 2,5 G.a. para um granada gnaisse e, charnockitos desta região apresentaram idades 3,1 G.a. (Rb/Sr em rocha total) e 1,7 G.a. (K/Ar em feldspato potássico, idades recalculadas, obtidas por Cordani et al., 1973), evidenciando componentes arqueanos e paleorpoterozóicos para o Complexo Juiz de Fora.

Campanha $(1980,1981)$ detalhou o Lineamento Além Paraíba, próximo à Três Rios, como uma zona de rochas miloníticas de evolução polifásica. As rochas granulíticas isotrópicas sofreram intenso retrabalhamento devido à deformação cataclástica e recristalização, transposição e migmatização insipiente na fácies metamórfica anfibolito alto. Durante o final do Ciclo Brasiliano ocorreram transcorrência, intrusões graníticas e 
pegmatitos, seguidas de reativação meso-cenozóica por falhas normais e intrusões alcalinas e de diques de diabásio.

Brenner (1980) caracterizaram os lineamentos estruturais do nordeste do Rio de Janeiro, especificamente na área que compreende a presente dissertação.

Foram identificados 3 domínios principais de lineamentos, definidos a partir de imagens de radar e satélite. O Domínio Migmatítico, correspondente à Serra dos Órgãos (conforme Rosier, 1965), o Domínio Gnáissico (correspondente à Série Paraíba de Rosier) ao longo do Vale do Rio Paraíba do Sul e o Domínio Costeiro, pobre em estruturas, associado à regiao costeira e representado por sedimentos cenozóicos.

$\mathrm{Na}$ área específica do trabalho de Brenner et al. (op.cit), estes autores caracterizaram as faixas cataclásticas do Domínio Gnáissico ao Norte do Rio Paraíba do Sul como uma feição estrutural peculiar em arco, com estrutura voltada para NW, onde as estruturas ao longo do Rio Paraíba são retilíneas, com direção N70E, ramificando em leque com direção variando até N30E, na porção extremo-setentrional da área estudada.

A inflexão destas faixas mostra direções semelhantes às da foliação regional, de alto ângulo, subvertical. Esta foliação é dada pela xistosidade (foliação milonítica) e pelo bandamento gnáissico composicional. A presença de lineação mineral, dad pela orientação de minerais alongados, é marcante, contida no plano de foliação, subhorizontal e, com sentido de caimento variável. Ocorrem também dobras intrafoliais isoclinais, de eixo subhorizontal, caindo ora para NE ora para SW, coincidente com a lineação mineral.

A forte deformação presente na área torna difícil a identificação das estruturas, embora localmente os autores tenham identificado transposição de foliação.

Os autores identificaram duas fases de deformação, sendo a última, concordante com a direção das faixas cataclásticas e a penúltima com estilo recumbente, plano axial subhorizontal, bem como bandamento composicional com estrutura estromatítica, subhorizontal, ao qual se sobrepõe as estruturas da última fase de deformação.

Brenner et al. (op.cit.) identificaram, nos milonitos e gnaisses miloníticos da área, a presença de foliação marcante, estruturas de fluxo e recristalização intensa, principalmente no feldspato potássico, plagioclásio e quartzo. Estas estruturas afetam rochas charnockíticas, granulíticas, migmatitos, quartzitos, mármores e rochas calciossilicáticas.

Os autores detalharam as faixas cataclásticas (N.A.: zonas de cisalhamento) da região de Santo Antonio de Pádua - Itaocara, identificando 4 principais zonas de cisalhamento. Ao Norte do Rio Paraíba do Sul, a foliação apresenta direção nordeste e mergulho de alto ângulo para sudeste. Este mergulho fica menos acentuado na medida 
que nos deslocamos da zona de Itaocara para a de Miracema, passando de vertical a subvertical para até $45^{\circ}$ ao Norte de Miracema.

As faixas ao sul do Rio Paraíba do Sul apresentam foliação vertical a subvertical com mergulho para noroeste. Ao longo do Lineamento Além Paraíba (N.A.: Zona de Cisalhamento Além Paraíba) a foliação predominante é vertical, passando a ter mergulho para sudeste à Norte do Lineamento e para Noroeste ao Sul do mesmo.

Brenner et al. (op.cit.) concluíram que as faixas cataclásticas do nordeste do Rio de Janeiro refletem zonas de cisalhamento de rejeito direcional dextrógiro, cujos processos atuantes foram essencialmente de carácter dúctil, originando milonitos e gnaisses miloníticos casracterísticos das mesmas. Estas faixas representariam as zonas de maior intensidade de deformação, intimamente associadas com os processos deformacionais regionais contemporâneos.

Os autores concluíram que o Lineamento São João do Paraíso (um pouco à leste da área estudada nesta dissertação) possui foliação vertical restrita à zona milonítica e trunca as estruturas regionais num arco, sendo as estruturas imediatamente adjacentes a ele de direção oblíqua às regioanis, porém concordante com o arco. Esta zona de cisalhamento, São João do Paraíso representaria os estágios finais de ativação das faixas cataclásticas, mostrando estruturas localmente discordantes do padrão regional.

Outros dois grupos de estruturas, com direções WNW e NW, teriam relação com tectônica rúptil pré-cambriana, possivelmente refletindo as últimas manifestações do Ciclo Brasiliano na área.

Oliveira (1980, 1981, 1982, 1983) propõe que todo o conjunto das rochas na parte sudeste da Faixa Ribeira (idade primária arqueana) foi afetado por intensa deformação e recristalização em ambiente de catazona durante o Ciclo Transamazônico, transformando charnockitos plutônicos em granulitos e milonitos.

O autor manteve esta mesma interpretação para o Complexo Paraíba, caracterizando em toda esta região as rochas de catazona, charnockitos e granulitos, com idade mínima de 1.8 G.a., comparáveis aos outros cinturões granulíticos do mundo.

Oliveira (op. cit.) caracterizou petrologicamente os granulitos da então Faixa Paraíba, que denominou Complexo Juiz de Fora, subdividindo este complexo em duas faixas, uma composta de charnockitos e granulitos com intercalações de kinzigitos, a Faixa Juiz de Fora e, outra composta de gnaisses, migmatitos, granulitos e rochas supracrustais, a Faixa Paraíba do Sul.

De acordo com seus estudos, os granulitos pertencentes ao Complexo Juiz de Fora (idade arqueana) poderiam ser restos depletados de fusão crustal, retrabalhados durante 
os ciclos transamazônico e brasiliano que afetaram suas rochas orto e paraderivadas, tendo o metamorfismo na fácies granulito ocorrido sob temperaturas entre 844 e $877^{\circ} \mathrm{Ce}$ pressão de 6 a $7 \mathrm{~Kb}$.

Barbosa et al. (1981), Barbosa \& Grossi Sad (1983) subdividiram o Complexo Juiz de Fora em três unidades: Unidade Comendador Venâncio, composta de charnockitos, quartzitos e diaftoritos; Unidade Gnaisses Raposo, composta de gnaisses migmatíticos e bandados e Unidade Itaperuna, composta de granulitos paraderivados, rochas básicas ígneas com afinidade toleítica, rochas intermediárias a ácidas de origem metamórfica ou metassomática com trend calcio-alcalino.

Os autores colocaram que as rochas granulíticas correspondem ao embasamento da sequência paraderivada, que foi soerguido por falhamentos verticais de carácter reverso.

As rochas do Complexo Juiz de Fora foram afetadas por granulitização sob alta PT e migmatização regional, formando mobilizados anidros, com tectonismo e metamorfismo retrógrado posteriores.

Siga Jr. $(1982,1989)$ estudando as rochas de alto grau da parte setentrional da Faixa Ribeira, a norte do RJ, delimitou o zoneamento metamórfico em regiões de epi, meso e catazona, com base no quadro geocronológico do Cinturão Ribeira. Mais tarde (1989) o autor caracterizou geocronologicamente os maciços charnockíticos da região sudeste, obtendo evidências, através do padrão isotópico, da ocorrência de processos geradores de rochas charnockíticas dominantemente ensiálicos.

O autor propôs que, no cenário tectônico da faixa costeira do sudeste do Brasil, o processo erosivo que exumou os maciços charnockíticos removeu em torno de $20 \mathrm{Km}$ de crosta, sendo difícil associar este processo de exumação com a simples formação da cadeia brasiliana. Considerou que a exumação desta provínica com rochas charnockíticas de meso - catazona ocorreu em duas etapas, uma durante a orogênese brasiliana e outra durante o Meso - Cenozóico, devido a um abaulamento adicional da litosfera, associado à formação de um grande rift, precursor do processo de deriva continental entre América do Sul e África, com a posterior formação do Oceano Atântico Sul.

Machado Filho et al. (1983) descreveram o Complexo Juiz de Fora constituído de unidade ígnea, composta de rochas ortoderivadas enderbíticas, trend misto calcio-alcalino a toleítico, enriquecido em ferro e, unidade sedimentar, composta de rochas paraderivadas granulíticas e kinzigíticas, trend calcio-alcalino.

Estes autores descreveram o Complexo Paraíba do Sul composto por gnaisses e migmatitos orto e paraderivados, gnaisses granitóides, granatíferos e rochas charnoenderbíticas, colocando as rochas paraderivadas do Grupo Italva, composto por 
hornblenda - biotita - plagioclásio gnaisses, calciossilicáticas, quartzitos e anfibolitos, pertencentes às Unidades Santana do Deserto e Rio Feio, de idade mais jovem, tectonicamente imbricadas com os gnaisses mais antigos.

Os Complexos Juiz de Fora e Paraíba do Sul teriam idade paleoproterozóica com retrabalhamento posterior brasiliano. As litologias do Complexo Juiz de Fora teriam conexão com as do Complexo Paraíba do Sul e Gnaisse Eugenópolis. O metamorfismo na fácies granulito seria anterior ao metamorfismo em fácies anfibolito.

Descreveram o Gnaisse Eugenópolis constituído de muscovita biotita gnaisse de idade paleoproterozóica, cronologicamente sobreposto aos Complexos Paraiba do Sule Juiz de Fora. A Suíte Intrusiva Espírito Santo foi descrita como constituida de granitóides sin e pós tectônicos, de idade neoproterozóica.

As estruturas predominantes na área do presente trabalho, no mapa de Machado Filho et al. (op.cit.), mostram trend NE-SW, com transcorrências na porção que abrange Santo Antônio de Pádua, Miracema e Lage do Muriaé (limite oriental da área desta dissertação) e, empurrões entre Lage do Muriaé e extremo norte ocidental.

Os falhamentos transcorrentes próximos ao limite oriental da área deste estudo mostram foliação com mergulhos de alto ângulo, sem atitudes identificadas no restante da área deste estudo, que pode ser vista em detalhe do mapa citado acima (fig. A.2.). 


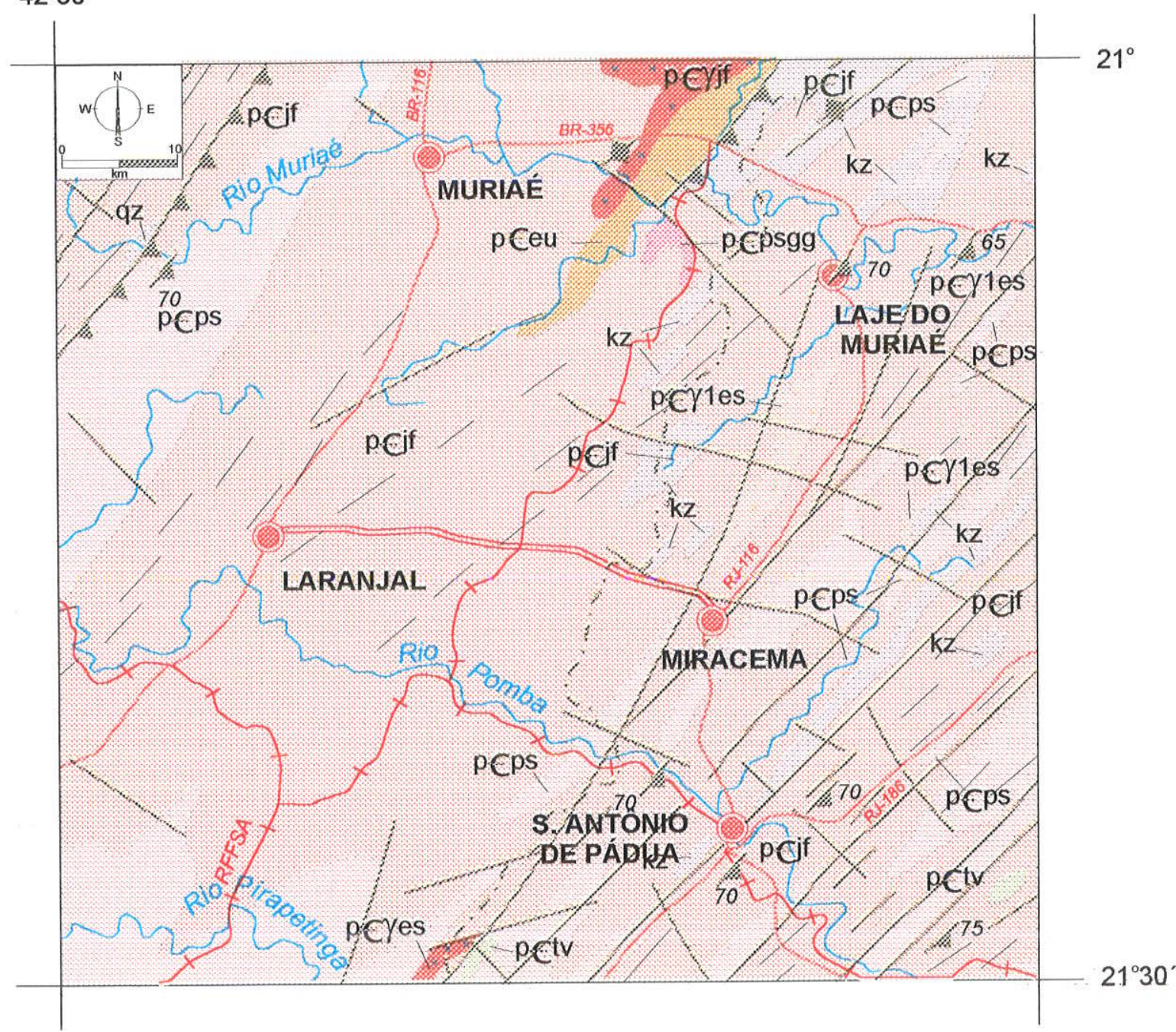

\begin{tabular}{|c|c|c|c|}
\hline \multicolumn{2}{|c|}{ peytes } & \multirow{2}{*}{$\begin{array}{l}\text { Suíte Intrusiva Espírito Santo (Neoproterozóico) } \\
\text { granitos sintectônicos migmatíticos (es); } \\
\text { granitos pós-tectônicos (1es) }\end{array}$} & \\
\hline$p 8$ & es: & & $70^{\circ} /$ atitude das litologias \\
\hline \multicolumn{2}{|c|}{ pCtv } & $\begin{array}{l}\text { Grupo Italva (Mesoproterozóico) } \\
\text { biotita gnaisses tonalíticos }\end{array}$ & \\
\hline \multicolumn{2}{|c|}{ pceu } & $\begin{array}{l}\text { Gnaisse Eugenópolis (Paleoproterozóico) } \\
\text { biotita-muscovita gnaisses }\end{array}$ & răo \\
\hline \multicolumn{2}{|c|}{ pcpsgg } & Complexo Paraíba do Sul (Paleoproterozóico) & \\
\hline \multicolumn{2}{|c|}{ peps } & gnaisses granitóides, granada gnaisses (psgg); & \\
\hline $\mathrm{kz}$ & $q z$ & \multirow{2}{*}{$\begin{array}{l}\text { Complexo Juiz de Fora (Paleoproterozóico) } \\
\text { gnaisses granulíticos, granulitos, charnockitos; } \\
\text { gnaisses kinzigíticos(kz); quartzitos (qz). }\end{array}$} & \\
\hline \multicolumn{2}{|c|}{ pCif } & & \\
\hline
\end{tabular}

Fig. A.2.: Detalhe do mapa geológico de Machado Filho et al. (1983) mostrando a área estudada; escala original 1:1.000.000. 
Machado (1984, 1986) detalhou petrograficamente as litologias do Grupo Paraíba do Sul, no RJ, subdividindo este grupo, nas regiões vizinhas às cidades de Vassouras e Bananal, em Unidade Inferior e Superior, identificando a presença de uma estrutura em flor positiva e regime de caráter divergente para a área da Faixa Paraíba do Sul.

A unidade de infraestrutura seria representada pela Sequência Quirino, composta de hornblenda - biotita gnaisses ortoderivados e unidades de supraestrutura composta dos biotita gnaisses, kinzigitos e metassedimentos, representada pelas sequências Barão de Vassouras, composta de biotita gnaisses, mármores e rochas calciossilicáticas, Sequência Vassouras, com granitóides e migmatitos miloníticos e Sequência Paracambi, composta de granitóides, anfibolitos e rochas calciossilicáticas. Os granulitos e charnockitos tonalíticos da Sequência Valença teriam sido afetados por quatro fases de deformação, segundo direções NE/SW, resultando em transposição e dobras abertas transversais.

O autor coloca que as idades das rochas do Grupo Paraíba do Sul ocorrem do Précambriano Superior ao Arqueano e foram afetadas por três eventos metamórficos.

Sugeriu um modelo de colisão continental com metamorfismo granulítico anterior ao anfibolítico, de onde evoluíram as rochas que formaram a Faixa Paraíba do Sul e, depois dos cavalgamentos, se instalaria a tectônica transcorrente.

Batista (1984) através de mapeamento geológico sistemático e estudos petrográficos definiu as Unidades Santo Eduardo, São Fidélis e Rio do Feio, na porção central da Faixa Ribeira e caracterizou petrologicamente as litologias granulíticas e charnockíticas do Complexo Juiz de Fora e propôs que a região do Sudeste de Minas sofreu deformação policíclica com retrabalhamento de unidades mais antigas (arqueanas) durante os períodos transamazônico e brasiliano.

Castro et al. (1984) propuseram a unidade Juiz de Fora como constituída predominantemente de rochas de origem metassedimentar, charnockíticas básicas, associadas a enderbitos, charnockitos e quartzitos subordinados e a Unidade Três llihas, que englobaria rochas que conservam evidências de derivação a partir de rochas charnockíticas e afins.

A Unidade Itaocara englobaria biotita gnaisses e anfibólio-biotita gnaises, associados a quartzitos, gnaisses kinzigíticos e leptinitos.

Hasui \& Oliveira (1984) consideraram os gnaisses que afloram na parte centro-sul da Faixa Ribeira como sendo correlacionáveis aos metassedimentos do Grupo Açunguí, restringindo o Grupo Paraíba do Sul aos gnaisses graníticos, dioríticos e monzoníticos, com intercalações de metassedimentos, mármores dolomíticos, rochas calciossilicáticas e 
xistos, com núcleos de granulitos preservados, aflorantes a norte da zona de cisalhamento de Itú-Jundiuvira.

Campos Neto (1984, 1991), Figueiredo \& Campos Neto (1989, 1993), Campos Neto \& Figueiredo $(1990,1992,1995)$ e Campos Neto et al. (1990) definiram três domínios crustais distintos na área dos estados de RJ-MG-ES, que teriam ocorrido como terrenos unidos durante a evolução de uma microplaca continental no Cambriano.

O primeiro terreno consiste das rochas retrabalhadas do Domínio Juiz de Fora onde ocorre a transição entre as fácies anfibolito e granulito (geoquímicamente caracterizadas em Figueiredo \& Campos Neto, 1993).

Este terreno teria se consolidado durante o Paleoproterozóico e evoluído, durante o Neoproterozóico, para uma margem continental ativa, com estabelecimento de um arco magmático continental.

Os domínios Paraíba do Sul, constituído por rochas supracrustais e Costeiro, constituido por rochas migmatíticas, seriam os outros dois terrenos suspeitos.

A junção destes terrenos no Cambriano teria formado uma microplaca que cavalgou o Cráton do São Francisco e este evento foi seguido de plutonismo no CambroOrdoviciano, representando os estágios finais de um ciclo tectônico.

Campos Neto e colaboradores (1995) caracterizaram o Complexo Juiz de Fora como petrograficamente composto de ortogranulitos migmatíticos e gnaisses migmatíticos cinzentos do Proterozóico Inferior afetados por retrabalhamento e granulitização no Proterozóico Médio a Superior.

O metamorfismo na fácies granulito, que afeta estas litologias, ocorre sintectônico à foliação regional e as rochas supracrustais estão empurradas para oeste na direção do Cráton do São Francisco.

As rochas charnockíticas, como as da Suíte Bela Joana, teriam origem em magmas afetados por uma fase fluida com razões variáveis de $\mathrm{CO}_{2} / \mathrm{H}_{2} \mathrm{O}$, enquanto os gnaisses com hornblenda e biotita, como os da Suite Angelim, teriam origem em magmas hidratados. Concentrações locais de fluidos carbônicos ou aquosos seriam os responsáveis pela natureza híbrida das litologias da área (com rochas verdes charnockíticas e gnaisses cinzentos) e de intrusões como as da Suíte Guarapari.

Estes autores concluíram que a evolução deste Arco Magmático (Rio Doce), cujas raízes ocorrem preservadas, seria similar à orogêneses tipo Andino, onde a convergência dominante é controlada por uma Zona de Benniof com mergulho moderado (normal). Este processo teria gerado complexos de núcleo metamórfico compressional num arco magmático continental. 
Para a área cortada pela Zona de Cisalhamento Além Paraíba, que afeta de modo relevante a área estudada nesta dissertação, os autores verificaram uma superposição de movimentos.

Na parte em que esta zona de cisalhamento afeta a Microplaca Serra do Mar e o Sistema de Empurrões Juiz de Fora, verificaram a geração de foliações sob condições de metamorfismo na zona da biotita, relacionadas a transporte levógiro subsequentes ao transporte dextrógiro que ocorreu sob condições de grau metamórfico mais elevadas.

As últimas deformações compressivas, ocorridas sob condições de metamorfismo de grau menos elevado, teriam provocado as estruturas antiformes e sinformes em diferentes escalas, associadas com estruturas de comprimento médio entre 3 e $5 \mathrm{~km}$.

As áreas com estruturas cilíndricas, trend NE- ENE ocorrem em leque convergente em direção ao interior do arco das estruturas antiformes, frequentemente reorientadas para NNE, quando próximas às zonas de cisalhamento de strike-slip.

Estas dobras ocorrem achatadas nos domínios transpressivos entre estas zonas de cisalhamento, com razões comprimento/largura maiores do que 1. Em área a sudeste da área estudada nesta dissertação, os autores verificaram evidências de zonas de cisalhamento rúptil-dúcteis ocorridas sob regimes extensionais, em alguns arranjos das falhas de deslisamento direcional.

Cordani \& Teixeira (1985) verificaram retrabalhamento crustal das rochas arqueanas e paleoproterozóicas mantélicas da parte sul do Cráton do São Francisco através de evidências isotópicas do padrão de crescimento das razões $\mathrm{Rb} / \mathrm{Sr}$. O quadro isotópico mostrou duas fases de acresção de material mantélico, a primeira entre 3,0 e 2,6 G.a. e a segunda entre 2,4 e 2,1 G.a.

Os autores colocaram que o limite temporal inferior para a implantação da unidade geotectônica brasiliana, o sistema Ribeira, estaria situado entre 1200 - 1000 M.a. e, o desenvolvimento deste sistema estaria situado entre 800 e 500 M.a., durante o Ciclo Brasiliano.

lyer, Choudhuri \& Cordani (1987) estudando as rochas granulíticas do Brasil colocaram que os granulitos geralmente ocorrem na forma de pequenos corpos e núcleos isolados de charnockitos, kinzigitos e leptinitos. Os estudos geocronológicos realizados pelos autores nas rochas da fácies granulito que ocorrem na Faixa Ribeira foram interpretados segundo (ao menos) duas gerações destas rochas de alto-grau.

Uma geração mais antiga de rochas granulíticas teria produzido complexos granulíticos entre 2,1 G.a. (Complexo Paraíba do Sul) e 2,7 G.a (Complexo Juiz de Fora) (idades de Cordani et al. 1973). 
Numa fase posterior, no final do Ciclo Brasiliano, durante o Neoproterozóico, teriam sido geradas rochas granulíticas e kinzigíticas de São Fidélis, Rio de Janeiro e Espírito Santo.

O terreno granulítico que contém os Complexos Paraíba do Sul e Juiz de Fora é considerado muito grande (> $\left.10.000 \mathrm{Km}^{2}\right)$ pelos autores, sendo constituído de granulitos bandados, enderbitos, charnockitos e migmatitos, gerados entre 2,7 - 2,1 G.a., rejuvenescidos há 700 M.a. Estas rochas são pertencentes a núcleos expostos do embasamento e com trend geoquímico calcio-alcalino, com LILE normal (não depletado).

Estes terrenos granulíticos exibem sinais de forte deformação e podem ter sido sedimentos de níveis crustais profundos pertencentes a cinturões colisionais, metamorfizados na fácies granulito e posteriormente erodidos ou, podem ter sido núcleos de embasamento, soerguidos tectonicamente de niveis crustais profundos por falhamentos de empurrão associados a compressão, para níveis crustais superficiais, durante a evolução de cinturões orogênicos mais jovens.

Grossi Sad \& Dutra (1988) subdividiram o Grupo Paraíba do Sul, da base para o topo em Formação Desengano, Formação Imbé e Formação Itaocara, esta última substituindo a Unidade Santo Eduardo e, Formação Euclidelândia, com mármores e anfibolitos, com metamorfismo em fácies anfibolito, nos paragnaisses, mármores, calciossilicáticas e anfibolitos e, fácies granulito nos charnockitos.

Os autores verificaram que a deformação possui uma zona de transição, com áreas dobradas desenvolvendo nova foliação penetrativa, sendo que, na parte central, o trendé E-NE e varia para N-NE. Propuseram para a região um modelo de colisão de arco de ilhas contra margem continental do tipo Atlântico, no Neoproterozóico.

Dayan (1988, apud Chrispim, 1989) Dayan \& Keller (1989), Dayan et al. (1993), Correa Neto et al. (1993), Correa Neto \& Dayan (1994) caracterizaram a natureza transpressiva da Zona de Cisalhamento Paraíba do Sul (em 1989) propondo a existência de uma estrutura do tipo em flor positiva para este regime transpressional (em 1993).

A existência desta estrutura em flor positiva justificaria a ocorrência dos movimentos verticais dos blocos envolvidos, os empurrões verticais e o estiramento na vertical.

A fábrica (eixos c de quartzo) evidencia mecanismo tipo rotacional, com sentido predominante do vórtice dextrógiro, condizente com marcadores cinemáticos tipo assimetria de dobras e sistemas porfiroclásticos encontrados na área.

Consideraram a presença das rochas charnockíticas e granulíticas, presentes na parte central Zona de Cisalhamento Paraíba do Sul, associadas diretamente ao soerguimento diferencial de rochas de níveis crustais profundos, formando pop-ups. 
As rochas na fácies anfibolito que afloram intercaladas e nas regiões adjacentes teriam origem da ascenção e hidratação, em níveis crustais superficiais, das sequências de rochas na fácies granulito, causando retrometamorfismo.

Segundo os autores, o soerguimento das porções inferiores à zona de cisalhamento teria ocorrido ainda durante sua movimentação, por efeito do componente de cisalhamento puro na porção em que o encurtamento/espessamento crustal foi concentrado.

O soerguimento durante a deformação por transcorrência seria indicado pela cristalização progressiva do ortopiroxênio (por recristalização dinâmica) hornblenda e biotita sincinemáticos.

Para Dayan \& Keller (op.cit.), o Lineamento Além Paraíba foi formado durante um evento transcorrente, predominando a deformação rotacional, com o eixo principal de extensão posicionado horizontalmente.

Houve também uma componente de encurtamento horizontal normal à zona milonitica principal (portanto, normal às zonas de cisalhamento principais), gerando estiramento vertical em regime de transpressão, contemporânea à componente rotacional principal da deformação.

Os autores sugerem que o ambiente transpressional na Zona de Cisalhamento Rio Paraíba do Sul seria devido à existência de uma estrutura em flor positiva que explicaria a coexistência de estiramento vertical com os movimentos transcorrentes principais, além do soerguimento de rochas oriundas de niveis crustais mais profundos.

Chrispim \& Tupinambá (1989) caracterizaram a deformação transpressiva entre as zonas de cisalhamento Paraíba do Sul (RJ) e Guaçuí (ES) (limites oriental, sul a à SE da área estudada nesta dissertação).

Partindo da hipótese da conexão entre estas duas zonas de cisalhamento, observaram feições estruturais nos blocos isolados da deformação cisalhante, encontrando evidências de tectônica transpressiva.

As feições estruturais observadas pelos autores foram: bandamento gnáissico representando uma foliação Sn dobrada suavemente com eixos caindo para N 30-50 E e plano axial subvertical $S n+1$ e, transposição desta foliação Sn e dos contatos litológicos por este dobramento, para uma direção N 40-50 E com caimento subvertical.

A transposição da foliação foi verificada pela ocorrência de um padrão assimétrico em $z$ das dobras (olhando ao longo do caimento do eixo), indicando que a superfície prétransposição teria direção W-NW mergulhando suavemente para NNE. 
Partindo deste pressuposto, Crispim \& Tupinambá (op.cit.) estabeleceram uma estratigrafia pré-transposição na área das zonas de cisalhamento Paraíba do Sul e Guaçuí.

Os autores observaram a atuação da tectônica transpressiva verificando que ocorre inflexão daquela foliação transposta (N40-50E com caimento subvertical) entre a zona de deformação em Três Rios, (ao sul da área de estudos desta dissertação) e a área estudada pelos autores, variando de N70E (em Três Rios) para N50E, caracterizando uma ligação entre as zonas de cisalhamento (a inflexão direciona o trend regional para N-NE).

Foi constatado que o regime de deslocamento das zonas de cisalhamento Paraíba do Sul e Guaçuí é dextrógiro e, a ligação entre estas duas zonas de cisalhamento representaria a deflexão de uma estrutura maior, dextrógira associada a transpressão.

A observação de mapas geológicos da área forneceu aos autores evidências de mega-estruturas tipo "strike-slip duplexes" transpressivos, que acomodam os blocos alóctones, em padrão anastomosado, entre as zonas de cisalhamento supra citadas.

Zimbres et al. (1990) propuseram a reinterpretação do significado geológico das datações KJAr existentes para a Faixa Ribeira considerando o gradiente geotérmico e seus efeitos no soerguimento regional das massas rochosas ali presentes.

Os autores colocaram que as idades KIAr em biotita são mais jovens da borda noroeste (600 M.a.) para o centro (450 M.a.) e, que este fato pode ser explicado pelas diferenças de soerguimento regional simultâneo e denudação da zona do eixo central da Faixa Ribeira.

$\mathrm{O}$ pico do metamorfismo na região foi estimado em $675^{\circ} \mathrm{C}$ e $4-5 \mathrm{~kb}, 18 \mathrm{Km}$ de profundidade. Considerando que a temperatura de bloqueio da biotita para o $\mathrm{Ar}$ éde $310^{\circ} \mathrm{C}$, estes dados indicam que o relógio $\mathrm{K} / \mathrm{Ar}$ da biotita foi resetado bem depois do pico metamórfico, provavelmente durante o soerguimento regional desta região da Faixa Ribeira e em niveis crustais muito superiores aos que ocorreu o metamorfismo. A taxa de soerguimento regional foi estimada em $77 \mathrm{~m} / \mathrm{M}$.a..

A partir destes dados, Zimbres et al. (op.cit) concluíram que as rochas aflorantes na área teriam passado pela isoterma de $310^{\circ} \mathrm{C}$ em momentos distintos, resultando no atual panorama termocrônico. Concluíram também que a abrupta redução das idades $\mathrm{K} / \mathrm{Ar}$ em biotita na zona de contato da Faixa Ribeira com o Cráton São Francisco pode ser atribuida à influência termal do metamorfismo brasiliano, sem ocorrência de um ciclo intermediário entre o Transamazônico e o Brasiliano.

Ribeiro et al. $(1990,1995)$ apresentaram uma reconstrução da evolução geológica meso a neoproterozóica no sul do Cráton do São Francisco onde um embasamento pré- 
1.8 G.a. e sua cobertura representariam duas unidades maiores separadas por uma discordância principal.

$\mathrm{Na}$ cobertura foram reconhecidos quatro ciclos deposicionais, com a caracterização de 3 bacias deposicionais, duas intracontinentais e uma bacia (Bacia Andrelândia) representando uma margem continental passiva do paleocontinente do São Francisco, que se estendia mais para sudeste em relação ao limite atual deste cráton.

Ebert et al. (1991, 1993, 1993b, 1994) propuseram que a evolução tectônica da Faixa Ribeira pode ser dividida em dois eventos tectônicos principais, sendo o primeiro evento de natureza tangencial, marcado por falhamentos de empurrão que causaram o cavalgamento dos blocos superiores para WNW e o segundo evento, marcado pelo desenvolvimento de um sistema de zonas de cisalhamento transcorrentes de sentido dextrógiro, que retrabalhou as rochas da área, afetando a fábrica gerada durante o evento tangencial.

Consideraram (1993b) que o arcabouço geotectônico da borda sul do Cráton do São Francisco e as feições estruturais que ali ocorrem seriam devidas à articulação de três blocos crustais, Brasília, São Paulo e Vitória, através de um processo compressivo principal de direção principal leste - oeste.

Definiram o "Cinturão Transpressivo Paraíba do Sul" (1993) como uma das feições estruturais mais importantes da Faixa Ribeira, considerado como uma entidade tectônica independente dos termos Cinturão Móvel Costeiro ou Faixa Ribeira, de conotação tectonoestratigráfica e que incluem domínios estruturais tangenciais pertencentes a diferentes eventos.

Observaram que há um decréscimo nas condições de metamorfismo nos terrenos afetados por este cinturão transcorrente, de norte para sul, indicando um provável soerguimento diferencial das rochas ali situadas.

As zonas de cisalhamento transcorrente de médio a alto ângulo, particularmente ao longo do Rio Paraíba, constituiriam flores assimétricas com mergutho para sudeste e poderiam estar conectadas em profundidade a uma grande zona de descolamento.

Neste contexto as zonas de cisalhamento de médio a baixo ângulo podem representar tanto os estágios iniciais da evolução tectônica do Cinturão Transpressivo Paraíba do Sul rotacionados pela transcorrência quanto corresponder a subdomínios de cavalgamentos laterais produzidos pela tectônica dextrógira.

Posteriormente (1994) colocaram que alguns granitóides da Faixa Ribeira (e.g. Complexo Socorro) são uma série calcioalcalina típica de zona de subducção, mas que os 
dados isotópicos indicam mais um material arqueano e paleoproterozóico retrabalhado do que a acresção de um arco magmático brasiliano tipo andino.

Consideraram que pouca crosta juvenil foi gerada no Brasiliano, indicando que a colisão continental que teria gerado a faixa envolveria no máximo um oceano de dimensões muito restritas.

Os autores propuseram um modelo de fusão parcial do manto superior, durante o espessamento das margens dos blocos colididos, afetadas pela transpressão e que estariam delimitados por profundas zonas de cisalhamento.

Para Ebert e colaboradores, a tectônica de escape lateral proposta em Vauchez (op.cit.) não precisa ser invocada para explicar o arcabouço estrutural presente no sudeste brasileiro, pois evidências de dados obtidos em campo e modelagem experimental mostraram que o Bloco São Paulo já teria formato acunhado quando de seu avanço para leste e posterior ajuste com os Blocos Brasília e Vitória. Isto permitiu a concentração da convergência através da partição da deformação entre transcorrências e encurtamentos crustais obliquos, sob tectônica transpressional.

A interpretação dinâmica entre estes três blocos crustais, ajustados entre suas margens convergentes, favorece a hipótese de que estes blocos tenham se individualizado a partir da ruptura de um anterior grande bloco continental, ao longo de uma junção tríplice.

O modelo tectônico reproduzido experimentalmente por Ebert et al. (1993), onde três bacias longitudinais estiveram interligadas durante sua evolução e inversão, explica a área de exposição e a difícil delimitação entre as litologias da Faixa Alto Rio Grande e da Faixa Ribeira, na intersecção destes cinturões.

As feições transpressivas do Cinturão Transpressiva Rio Paraíba do Sul (Ebert et al., 1993) condizem com o ângulo de convergência W-E entre os blocos crustais, inclusive elipsóides de deformação oblatos, tectonitos SL e estruturas associadas às lineações direcionais das zonas de transcorrência, que indicam encurtamento normal à foliação de alto ângulo e extensão vertical.

As estruturas em flor presentes na área evoluíram a partir de zonas de recobrimento e estruturas em duplexes, com exemplos expressivos ao longo do Vale do Rio Paraíba, na Serra do Mar, onde as bordas NW mergulham para SE e as opostas, para NW. Estas calhas no centro da estrutura positiva mostram alternância de dobras e zonas miloníticase seriam o "eixo da divergência"da Faixa Paraibides de Ebert (1968).

Segundo Ebert et al.(op.cit), em níveis crustais inferiores, como no Cinturão Transpressivo Paraiba do Sul, as deformações não se processaram apenas por 
movimentação diferencial entre segmentos rígidos (horse tails) mas também através de deformações plásticas internas, como veios apíticos dobrados perpendicularmente e boudinados na direção do eixo cinemático $Y$ da foliação milonítica, por estruturas assimétricas como foliação S-C no plano cinemático $Y Z$ e por estiramento/achatamento intracristalino dos agregados minerais. Estas deformaçōes foram veirficadas pelos elipsóides de deformação oblatos, calculados em escala de amostra.

A dificuldade de correlacionar faixas de mesma vergência em perfis maiores é característica da presença de estrutura em flor, que se sucedem ao longo de todo o perfil do Cinturão Transpressivo Paraíba do Sul até o litoraL, em todas as escalas, inclusive com alternância de segmentos negativos e rejeitos levógiros, necessários para acomodar a heterogeneidade da deformação.

Vários fatores contribuíram para a complexidade do padrão geométrico e cinemático das estruturas tipo flor entre a Serra da Mantiqueira e a Serra do Mar, como a intensidade das deformações e sua interação durante a deformação progressiva.

Ebert et al. (op.cit.) propôs o uso do termo Cinturão Transpressivo Paraíba do Sul para a organização geométrica gerada pelo expressivo evento dúctil que configurou a atual estruturação NE-SW do Sudeste brasileiro.

Strieder (1993) através de análises detalhadas das estruturas lineares na região que abrange a área desta dissertação, observou que a Cunha de Guaxupé está truncada pelas estruturas ligadas ao processo colisional da Orogênese Rio Doce (Campos Neto \& Figueiredo, 1992).

Estas estruturas, extensas zonas de cisalhamento direcional dextrógiro, correlatas à Zona de Cisalhamento Paraíba do Sul, seriam decorrência natural da aproximação e colisão oblíqua de blocos continentais, Blocos São Paulo, Brasilia e Vitória, propostos por Ebert et al. (op.cit.) e, não o resultado da colisão e justaposição de blocos irregulares ou terminação de cráton antigo, como proposto em Vauchez et al.(1992, 1994).

Para Strieder (op.cit.), a aproximação e colisão do Cráton do COngo para originar a Província Estrutural Mantiqueira encontrou a Província Estrutural Tocantins já estabelecida, na Cunha de Guaxupé (à sudoeste da área deste dissertação). Em grande escala, a aproximação do Cráton do Congo com o bloco continental formado pelos crátons do São Francisco - Guaporé interpõe bordas continentais não combináveis e resulta numa diferenciação do proceso colisional: convergência frontal no segmento Norte (que abrange a área específica desta dissertação) e convergência oblíqua no segmento Sudoeste da Província Estrutural Mantiqueira. 
Pinto \& Padilha (1993) e Pinto (1995) dividiram o Complexo Juiz de Fora em Unidade Migmatítica, composta por gnaisses e migmatitos com paleossoma básico e enderbitos, noritos, enderbitos e charno-enderbitos, toleítos baixo $\mathrm{K}$; e Unidade Metassedimentar, composta de kinzigitos, gnaisses aluminosos e quartzitos, trend misto, toleítico e calcio-alcalino; granitóides granulíticos com alto alumina; idades arqueanas para os protólitos com retrabalhamento transamazônico e brasiliano.

O metamorfismo granulítico teria origem por metassomatismo carbônico, anterior ao de fácies anfibolito, gerando granulitos básicos a partir de basaltos gerados em ambiente de arcos de ilha ou bacias de retroarco e granulitos ácidos a intermediários, a partir de granitos de ambientes de arco vulcânico.

Em 1995, Pinto \& Padilha (op.cit.) propuseram um modelo de evolução para o Sudeste do Brasil, abrangendo o Cráton do SãoFrancisco e a Província Mantiqueira. Para a região estudada por estes autores foi proposto que a Província Mantiqueira (terrenos granulíticos com registros de idades tranzamazônicas e arqueanas) e o Cinturão Ribeira (brasiliano) ocorrem numa faixa de superposição, com limites ao sul de Juiz de Fora e prolongando em arco para sudoeste e nordeste.

Conforme sua proposta, a Província Mantiqueira entrou em processo de colisão com - Cráton do São Francisco no final do Arqueano, início do Paleoproterozóico, sentido leste - oeste, gerando batólitos graníticos calcio-alcalinos de arco magmático e bacias marginais. Os sedimentos bacinais correspondem ao Complexo Mantiqueira (fácies anfibolito), Super Grupos Minas e Rio das Velhas e Grupo Dom Silvério.

Com a continuação do processo colisional ocorreu o cavalgamento das rochas granulíticas da crosta inferior (Complexo Juiz de Fora) sobre as rochas de grau metamórfico menor (inversão estratigráfica do grau metamórfico), com vergência para $\mathrm{N}$ $\mathrm{NE}$, gerando transposição das estruturas, deformação das bordas das placas envolvidas na colisão e intensa imbricação tectônica. O pico deste processo ocorreu por volta de 2 1,9 G.a.

Após um período de estabilidade, a partir do Mesoproterozóico (1,8 - 1,6 G.a.), um processo de abertura teria iniciado, com ascenção de material mantélico, granulitização, migmatização e fusão generalizada em toda a região e, sedimentação associada, no ambiente da fossa gerada pela abertura. A posterior inversão deste processo, gerando o fechamento do suposto oceano, gerou batólitos graníticos calcio-alcalinos (e.g. Serra dos Órgãos, RJ; Estrela, ES) conforme uma estrutura de arco magmático.

Concomitantemente, os sedimentos pelítico-psamíticos foram carreados para a fossa, na zona de subducção, metamorfisados e deformados (Complexo Paraíba do Sul) gerando 
novas estruturas planares penetrativas e transposição das pré-existentes. Este processo de fechamento foi encerrado com magmatismo tectônico e transcorrências, representados por granitos diferenciados presentes à sudeste das Zonas de Cisalhamento Além Paraíba e Guaçuí.

Segundo Pinto e colaboradores, as rochas granulíticas à noroeste do Lineamento Além Paraíba são feições tectônicas. As estruturas ao sul, na parte onde a área desta dissertação está localizada, são consideradas como nappes de rochas granulíticas prébrasilianas, correlatas ou pertencentes ao Complexo Juiz de Fora.

Trouw (1992), Trouw \& Pankhurst (1993), Nogueira \& Trouw (1993), Nogueira (1994), Trouw et al. (1994) realizaram estudos sobre o metamorfismo e deformação para terrenos localizados a sul do Cráton São Francisco, concluindo que a deformação, na Faixa Ribeira, pertence ao evento termotectônico brasiliano e, a Faixa Alto Rio Grande foi interpretada como zona de interferência entre a Faixa Brasília e a Faixa Ribeira, portanto, não caracterizando uma faixa independente.

Os autores estudaram o Complexo Mantiqueira, composto de ortognaisses e o Complexo Juiz de Fora, composto de granulitos básicos a ácidos, ortoderivados, sendo que este metamorfismo granulítico seria contemporâneo à formação da bacia que gerou o Grupo Andrelândia, anterior à primeira fase de deformação.

Os granulitos que ocorrem na região são interpretados como gerados a partir de rochas anfibolíticas metamorfisadas na fácies granulito, com origem em frente de fluidos ricos em $\mathrm{CO}_{2}$, sob temperaturas entre $750-800^{\circ} \mathrm{C}$ e pressão entre $4-6 \mathrm{~Kb}$, indicando ambiente de base da crosta. Outro tipo de granulitos, de origem tectônica,ocorre associado à zonas miloníticas, próximas aos falhamentos de empurrão, com rochas encaixantes afetadas por anatexia.

Trouw et al. (1980, 1982, 1993) colocaram que a região SW de Minas Gerais sofreu uma forte deformação compressiva, que foi responsável por migmatização e também pelos dobramentos e empurrões que interdigitaram as rochas do embasamento com os metassedimentos. Posterior à esta compressão foram formadas novas zonas de cisalhamento, gerando ou remobilizando as rochas migmatíticas e granitóides presentes, e uma fase posterior, distensiva, ainda apresenta evidências de deformaçao dúctil.

Nogueira e Trouw (op.cit.) interpretam a faixa milonítica que atravessa a região de Juiz de Fora (à sudeste de MG e sudoeste da área desta dissertação) como contato tectônico de empurrão, considerando este falhamento como divisor entre as rochas do Complexo Juiz de Fora e Grupo Mantiqueira. 
Vauchez et al. (1992, 1994) consideraram um modelo de evolução geológica com a evolução conjunta das Faixas Araçuai e Ribeira, que poderia ter resultado da convergência e colisão de alto ângulo da extremidade SSW da placa Cráton do Congo - Cráton São Francisco com a mega-placa do Gondwana Ocidental, durante o Ciclo Brasiliano. Esta colisão teria originado escape lateral dos blocos na terminação meridional do cráton.

Segundo este modelo, a direção de fluxo predominante poderia ser explicada em função da variação das propriedades reológicas da litosfera induzidas pela extremidade sul do cráton. A ausência de confinamento teria propiciado a acomodação da convergência através de um regime tectônico dominado pela deformação transpressiva e escapes laterais ao longo das zonas de cisalhamento transcorrentes dextrógiras NE-SW.

A deformação seria dominada por componentes rotacionais, que permitem o escape de material ao longo destas zonas de cisalhamento cisalhamento transcorrente.

A deformação vertical neste domínio decresceria rapidamente conforme a distância do bordo sul Cráton do São Francisco, que funcionou como bloco rígido, controlando as estruturas ali presentes. (vide fig.A.3.)

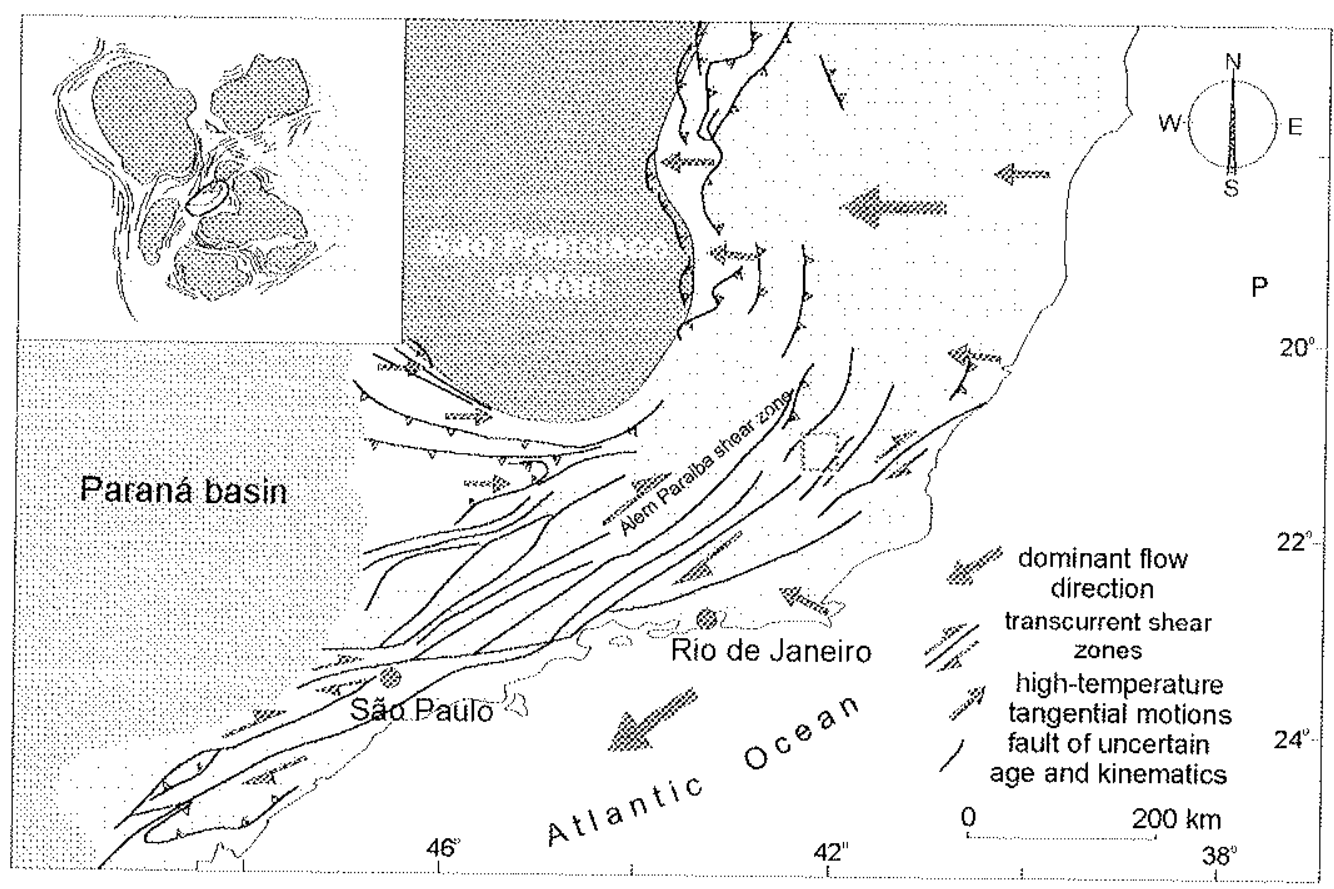

Fig.A.3.: Mapa com o contexto estrutural e cinemático do sudeste do Brasil, (modificado de Vauchez et al., 1994). O mapa mostra cinemática $E-W$ na altura do paralelo 20 , onde predomina a tectônica de empurrão e, onde o Cráton do Congo teria colidido frontalmente com a terminação sul do Cráton do São Francisco. A cinemática mostra direções progressivamente oblíquas e predomínio da tectônica transcorrente, provavelmente devido ao escape lateral de massa em direção ao sul, ao longo da Zona de Cisalhamento Além Paraíba, com trend NE-SW, que teria acomodado este escape de rochas através de deslocamentos direcionais dextrais. 
Machado \& Endo (1993, 1993b, 1994), Endo \& Machado (1993, 1993b) e Machado \& Demange (1994) propuseram um modelo cinemático em dois estágios, de idade brasiliana, compativel com uma convergência lateral obliqua, com mudança de orientação dos vetores tectônicos transpressivos de E-W para N-S.

Caracterizaram o Cinturão de Cisalhamento Atlântico (1993b) como um cinturão de natureza transpressional com estruturação linear paralela à costa sul-sudeste do Brasil e leste do Uruguai, com extensão superior à $2900 \mathrm{Km}$, desde o paralelo $11^{\circ}$ ao paralelo $30^{\circ}$ , com orientação NE-SW no setor meridional e NNE-SSW no segmento setentrional.

Este cinturão de cisalhamento é composto por dpis sistemas principais: O Cinturão de Cisalhamento Paraíba do Sul, ao norte e o Dom Feliciano, ao sul.

Segundo Machado \& Endo (op. cit.) o Cinturão de Cisalhamento Paraíba do Sul (parte da área da presente dissertação) mostra evolução tectono-estrutural sob regime transpressional, configurando sistemas geométrica e cinematicamente integrados, no contexto de uma estrutura em flor positiva com cinemática dextrógira.

Este Cinturão de Cisalhamento Atlântico apresenta magmatismo granítico brasiliano, associado às zonas axiais da principais zonas de cisalhamento e ao longo das anomalias geofísicas lineares, sugerindo que estas estruturas estejam ligadas à descontinuidades crustais expressivas, desempenhando importante papel na contituição do arcabouço tectono estrutural da região e no controle da colocação deste magmatismo.

Ainda em 1993, Endo \& Machado colocaram que a Província Tectônica do Atlântico seri uma entidade brasiliana representando um domínio móvel do sistema transpressional instalado entre dois blocos rígidos: O Cráton Amazônico e o Cráton do Congo, que teriam colidido obliquamente, sob regime convergente de direção E-W, com os mecanismos transpressionais desempenhando papel fundamental na acresção e colagem continental brasiliana.

Para Machado e colaboradores, a convergência frontal, observada na porção setentrional do Cinturão de Cisalhamento Atlântico na altura do médio Vale do Rio Doce, na Zona de Cisalhamento Paraíba do Sul, seria efeito do escape tectônico lateral positivo promovido pelos movimentos transpressivos dextrógiros oriundos da zona focal do Cinturão de Cisalhamento Atlântico.

A inversão do regime cinemático, criando condições para a implantação do ambiente transtensional, propiciou a ascensão e colocação de magmas graníticos neste cinturão no intervalo de 620-550 M.a.. 
O modelo proposto por Machado e colaboradores difere dos modelos de acresção lateral e escape tectônico na medida em que implica também em uma tectônica de acresção longitudinal em relação aos sistemas de cisalhamento circundantes.

Neste modelo, o vetor compressivo (E-W) que teria gerado o arranjo geométrico e cinemático das zonas de cisalhamento que ocorrem na região é interpretado como produto de tectônica transpressional dextrógira que teria promovido a colagem tectônica lateral dos terrenos da Cunha de Guaxupé com os do Sistema de Cisalhamento Paraíba do Sul, desenvolvendo nestes uma trama estrutural dúctil penetrativa.

$\mathrm{O}$ arcabouço estrutural seria produto de reativação controlada pelas estruturas préexistentes, com o vetor compressivo não-coaxial (transpressional levógiro) orientado segundo direção N-S.

Estes autores consideraram que as transcorrências que ocorrem na Faixa Ribeira, consideradas D3 por outros autores que trabalham na região, não seriam tardias ao processo, mas de instalação precoce na evolução desta faixa móvel.

A região focal da deformação transpressiva estaria situada mais ao sul, no RJ, na zona axial do Sistema de Cisalhamento Além Paraíba e, seria a causadora do escape lateral de massa, segundo o padrão de mega-estrutura em flor positiva, gerando os empurrões presentes nas partes distais à zona focal.

Heilbron (1993) e Heilbron et al. (1994, 1994b) Heilbron et al. (1995, 1997, 1998 , 1999) apresentaram um mapa tectônico com perfil estrutural de uma seção entre Jacutinga (MG e Mangaratiba (RJ) cruzando a "Megassinforme do Rio Paraiba do Sul", a sudoeste do Rio de Janeiro.

Foram propostos três domínios tectônicos para a região: domínio tectônico Paraíba do Sul ocupando a parte central (e topo) da megassinforme, sobreposto por tectônica de empurrão ao domínio tectônico Juiz de Fora (interdigitação das rochas granulíticas do Complexo Juiz de Fora com o Grupo Andrelândia) e, domínio tectônico Andrelândia, que seria o embasamento da região (em 1983).

A "Megassinforme" estaria superposta ao padrão estrutural caracterizado por falhamentos de empurrão sub-horizontais, durante os quais teria se desenvolvido a foliação principal.

Heilbron (op.cit.) subdividiu a região entre Bom Jardim de Minas (MG) e Barra do Piraí (RJ) em domínios tectônicos com ciclos deposicionais e associou a evolução desta área com processos de delaminação crustal e subducção tipo $A$ e underplating com entrada de material mantélico que teria causando encurtamento crustal devido a um sistema de nappes das porções superiores da litosfera. 
Heilbron e colaboradores propuseram o abandono do termo Faixa Alto Rio Grande em troca de Ciclo Deposicional Andrelândia e verificaram uma possibilidade de correlação entre os metassedimentos do Grupo Paraíba do Sul com os do Ciclo Deposicional Andrelândia, aflorantes mais a norte.

Os autores (em 1994, 1995) propuseram uma evolução tectono-metamórfica na qual a convergência crustal do setor central da Faixa Ribeira ocorreria através de dobramentos e empurrões sob regime dúctil, cujos estágios tardios envolveram convergência oblíqua com deformação distribuilda por todo o orógeno.

Heilbron et al. (op.cit) apresentam para a parte central da Faixa Ribeira uma subdivisão para a Orogênese Brasiliana em três períodos, sin pré e pós colisional.

No período sin-colisional (590-563 M.a.) a deformação principal (D1+D2 e M1) causou o empilhamento tectônico e posterior movimentação obliqua (inversa e dextrógira), com metamorfismo de pressão média a alta e zoneamento inverso.

O período pós-colisional (535-520 M.a.) estaria relacionado à fase de deformação tardia D3 que seria a responsável pela implantação das zonas de cisalhamento direcional dextrógiras, metamorfismo com regime de pressão mais baixo e fusão parcial do embasamento e rochas supracrustais da porção mais interna da faixa.

No período pós-tectônico (503-402 M.a.) estaria ocorrendo a transição do regime compressivo para o regime distensional dominante no Fanerozóico, com a geração de granitóides associados às rochas do Complexo Paraíba do Sul.

Heilbron et al. (op.cit.) enfocando a litogeoquímica dos ortogranulitos do Complexo Juiz de Fora propõe subdivisão em associações tectônicas distintas.

A primeira associação seria representada por duas séries calcio-alcalinas geoquimicamente semelhantes aos arcos magmáticos modernos e a outra constitui dois grupos de rochas básicas, um toleítico e outro com basaltos transicionais a alcalinos, ambos indicando ambiente distensional intracontinental.

O modelo tectônico colocado por Heilbron (op. cit.) visualiza as raízes de um arco magmático cordilherano extensional do Paleoproterozóico que estaria localizado na borda de uma margem cratônica arqueana, como resultado de convergência continental no Ciclo Tranzamazônico.

Este modelo prevê o retrabalhamento de uma crosta continental mais antiga $e$ acresção juvenil seguida de metamorfismo na fácies granulito possivelmente causado por underplating magmático sob a crosta continental, podendo sugerir longa residência na crosta inferior. 
Mais tarde (1999) a autora retoma com alterações, a divisão de Machado Filho et al. (1983), considerando o "Grupo" Paraíba do Sul composto por paragnaisses e mármores do terreno ocidental da Faixa Ribeira e o Grupo Italva composto por ortognaisses do terreno oriental.

Tupinambá (1993, 1993b, 1993c) estudou aspectos estratigráficos, deformacionais e metamórficos de uma área próxima, à leste da área da presente dissertação.

O autor questionou a nomenclatura estratigráfica referente aos Complexos Juiz de Fora e Paraíba do Sul na região sudeste do Brasil, Zona da Mata Mineira, entre Itaperuna (CJF) e Italva (CPS), e entendeu que o termo Complexo Juiz de Fora deveria ser abandonado na área, e que as rochas do Complexo Paraíba do Sul atingiram metamorfismo na fácies granulito. Sugeriu também que o termo "Complexo" Paraíba do Sul fosse substituido por "Grupo"Paraiba do Sul, pois foi possivel separar sequências metassedimentares deste grupo (Suíte Metacarbonática São Joaquim, Gnaisse Bandado Santo Eduardo e Suite Metassedimentar Catalunha) de rochas intrusivas posteriores (Granitóide Italva e Diatexito São João do Paraíso).

Tupinambá (op. cit.) coloca que as variações metamórficas e deformacionais existentes entre as litologias aflorantes em Itaperuna e Italva não configuram razão para distinção em unidades estratigráficas diferentes, pois as litologias não apresentam composições diferentes.

Nogueira $(1994,1999)$ estudando as litologias do Complexo Juiz de Fora verificou que o metamorfismo em fácies granulito ocorreu sob $T>850^{\circ} \mathrm{C}$ e baixa $\mathrm{P}$, entre 4 e $6 \mathrm{~Kb}$ e que as inclusões fluidas mostram predominância de fluidos carbônicos com evolução do metamorfismo tipo IBC.

Através da análise destes dados o autor coloca que as rochas ortognáissicas pertencem ao embasamento (Complexos Mantiqueira e Juiz de Fora) e foram geradas durante o evento termotectônico Tranzamazônico (2,2 - 1,9 G.a.) retrabalhando uma crosta arqueana com idades entre 2,9-2,6 G.a. As idades em torno de 3,3 G.a. foram obtidas nas rochas do Complexo Barbacena.

Costa et al. (1995, 1997, 1997b, 1998) verificaram, na porção setentrional da Faixa Ribeira (em área situada à Norte da área desta dissertação) evidências de colisão com sentido E-W entre placas continentais, gerando acresção continental, durante o Neoproterozóico.

Os autores observaram a alternância entre tectônica tangencial e deformação por falhas de strike-slip, nas litologias da área. 
O forte componente transpressional das zonas de cisalhamento presentes na região foi reconhecido pelos autores através da presença de lineações de baixo ângulo sobre foliações de alto ângulo nas suas margens e, lineações de estiramento mineral direcionais associadas às foliações de baixo ângulo, onde se desenvolveram rampas laterais.

Caracterizaram os domínios de foliação de baixo ângulo associados com deformação tangencial e domínios com foliação de alto ângulo de mergulho, associados à deformação de strike slip.

Nas áres de ocorrência dos Complexos Juiz de Fora e Paraiba do Sul, estudadas pelos autores, foi verifica da foliação de baixo ângulo com direções N-S mergulhando para leste e lineações de estiramento mineral indicativas empurrões sob de rampas frontais em direção a Oeste.

Figueiredo \& Teixeira (1996) colocaram que as litologias do Complexo Juiz de Fora teriam origem no Arqueano, retrabalhamento num ambiente de arco magmático maduro, durante o Ciclo Tranzamazônico, em margem continental ativa e, este terreno teria cavalgado para oeste, sobre os terrenos do Cráton São Francisco.

Machado et al. (1996) verificaram idades arqueanas para os protólitos do embasamento, 2.9 G.a. e idades transamazônicas para o embasamento gnáissico e granulítico, 2.1 G.a. Dataram também a remobilização regional deste embasamento, das rochas supracrustais e granitóides associados, que ocorreu durante um importante evento há 590-565 M.a., provavelmente responsável pela tectônica de empurrão e pelo desenvolvimento das zonas de cisalhamento dextrógiras ali presentes.

Os autores verificaram também um evento metamórfico há 535-520 M.a., que afetou os complexos Paraíba do Sul e Costeiro e atividades tardi a pós-tectônicas, há 503-492 M.a..

A partir destes dados, Machado et al. (op. cit.) concluíram que as rochas do embasamento encontradas em domínios alóctones da parte central da Faixa Ribeira representam uma extensão das unidades presentes na parte sul do Cráton São Francisco, o que estenderia para leste os atuais limites deste cráton. (vide fig.A.4.) 
a)

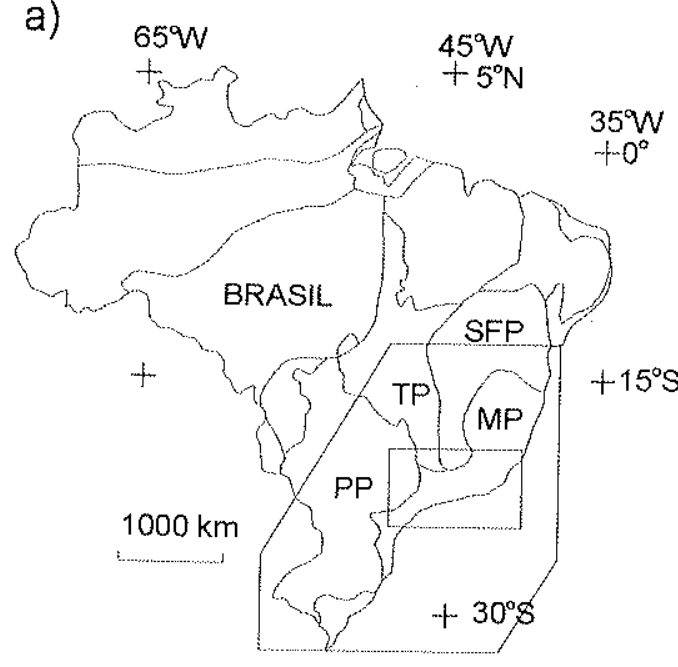

b)

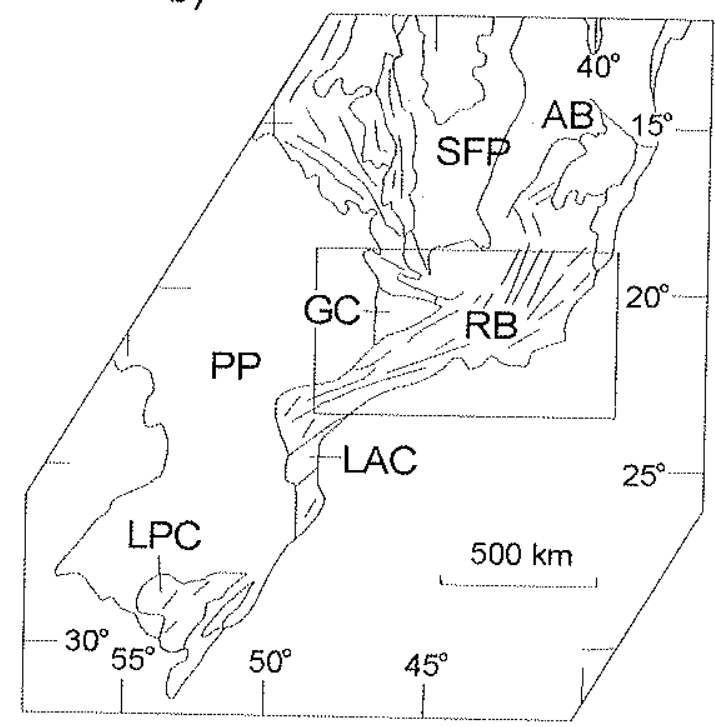

c)

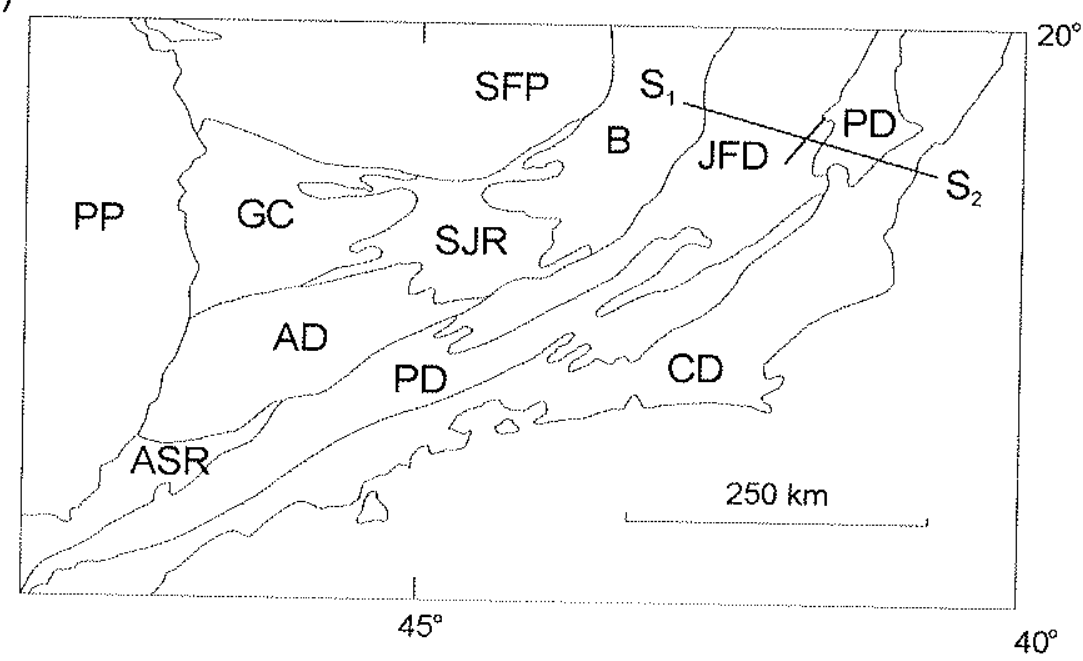

Fig. A.4: Províncias geológicas do Brasil, unidades geológicas do sudeste e Faixa Ribeira (extraída de Machado et al., 1996)

a) Províncias geológicas do Brasil (adaptado de Almeida \& Hasui, 1984). MP: Prov. Mantiqueira, PP: Prov. do Paraná (Fanerozóico); SFP: Prov. São Francisco (Arqueano, Tranzamazônico); TP: Província Tocantins (Brasiliano).

b) Principais unidades geológicas do sudeste do Brasil. AB: Faixa Araçuaí; GC: Complexos Varginha, Guaxupé e Campos Gerais; LAC: Cráton Luiz Alves; LPC: Crárton de La Plata; RB: Faixa Ribeira; SFP: Província São Francisco.

c) Principais unidades geológicas na porção central da Faixa Ribeira. (área estudada em Machado et al., 1996). AD: Domínio Andrelândia; ASR: Complexos Açungui e São Roque; GC: Complexos Varginha, Guaxupé e Campos Gerais; JFD: Domínio Juiz de Fora, PD: Domínio Paraíba do Sul; SJR: Complexos São João del Rei e Andrelândia.S1 e S2: seção transversal de Söllner et al., 1991.

Duarte et al. (1997) Duarte (1998) abordam a geoquímica dos ortognaisses em fácies granulito do Complexo Juiz de Fora colocando os granulitos máficos como toleítos evoluídos a partir de mesmo magma parental, os granulitos intermediários e félsicos, 
calcio-alcalinos, relacionados petrogeneticamente e os granulitos máficos sem relação petrogenética com os demais.

Duarte (1998) adotou a compartimentação tectônica de Heilbron $(1993,1995)$ e detalhou petrogeneticamente os domínios Juiz de Fora, Paraíba do Sul e Andrelândia, na porção central da Faixa Ribeira, a leste do Cráton do São Francisco.

Para esta autora, o Domínio Juiz de Fora é constituído de uma interdigitação entre orotgranulitos pré-1,8 G.a. do Complexo Juiz de Fora e rochas metassedimentares da Unidade Jardim Glória e Grupo Andrelândia.

O Domínio Juiz de Fora teria embasamento composto de granulitos ortoderivados, paragnaisses e rochas associadas da Unidade Jardim Glória e ortognaisses da Suíte Quirino-Dorandia e, rochas supracrustais englobando paragnaisses e rochas associadas da Unidade Jardim Glória, relacionadas ao Domínio Andrelândia.

O embasamento e as rochas supracrustais foram ambos intrudidos por leucogranitos e charnockitos, apresentando contatos tectônicos interdigitados.

As rochas do Complexo Juiz de Fora possuem composição média granodiorítica e presença de ortopiroxênio. Foram afetadas por retrometamorfismo parcial e migmatização anterior à granulitização.

Duarte propõe uma evolução tectônica desde um ambiente compressivo de raiz de arco magmático, quando da formação dos protólitos destas rochas, até um ambiente distensivo que acolheu o metamorfismo granulítico que afetou na região, promovido por underplating magmático.

O Domínio Paraíba do Sul possui embasamento constituído de ortognaisses da Suíte Quirino Dorândia e, rochas supracrustais representadas por biotita gnaisses, com foliação milonítica quando em contato com as rochas do Domínio Juiz de Fora.

Valladares et al. (1997, 1997b) estudaram a geoquímica e geocronologia dos gnaisses paleoproterozóicos do Complexo Paraíba do Sul (ortognaisses da Unidade Quirino) em Barra Mansa RJ, colocando sua geração em 2,185 - 2,169 G.a.(U/Pb em zircão) e temporalmente relacionados com a evolução do Ciclo Tranzamazônico.

Idades mínimas de 2,846-2,981 G.a. em zircão indicaram a existência de crosta arqueana como fonte de $\mathrm{Pb}$ para os gnaisses analisados. Estudos geoquímicos evidenciaram duas suítes calcioalcalinas, uma de médio a alto potássio e outra de alto potássio enriquecida em LILE.

Estes autores sugerem a correlação tectônica das litologias da Unidade Quirino com granitóides calcio-alcalinos de ambiente de arco magmático, gerados durante a orogênese 
tranzamazônica (2,2-1,9 G.a., U/Pb em zircão e titanita), com retrabalhamento da unidade Quirino, que sofreu retrabalhamento durante a Orogênese Brasiliana, entre 605-503 M.a. .

Através de idades $\mathrm{Pb} / \mathrm{Pb}$ (laser), os autores concluíram que os metassedimentos que ocorrem nos domínios tectônicos Juiz de Fora, Andrelândia e Costeiro, na porção central da Faixa Ribeira, foram derivados predominantemente da erosão de crosta tranzamazônica, entre 2,0 - 2,3 G.a., com contribuição subordinada de crosta arqueana, entre 2,6-2,9 G.a., corroborando com os dados U/Pb existentes para os gnaisses esta área, formados entre 2,134-2,185 G.a., que também contém cristais de zircão arqueanos de idades mínimas entre 2,846 - 2,981 G.a.

Ebert \& Hasui (1998) consideraram que os sistemas transcorrentes presentes na Faixa Ribeira estão superimpostos aos sistemas de empurrão, representando o final da tectônica colisional frontal de placas continentais envolvendo encurtamento e espessamento crustal significativos. Esta colisão evoluiu formando rampas transpressionais nas bordas continentais envolvidas. Ocorreu uma partição temporal entre domínios tangenciais e de strike-slip devidos à obliquidade da convergência das placas nesta região.

Pedrosa Soares et al. (1998) verificaram evidências de crosta oceânica no leste brasileiro, excluindo a possibilidade de evolução exclusivamente ensiálica para a orogênese Araçuaí - West Congo.

A quebra de Rodínia, ao longo da orogenia Araçuai - West Congo e seus craatons adjacentes, foi precedido por enxames de diques máficos e magmatismo granítico anorogênico há 1050 - 950 M.a.. A abertura inicial evoluiu a partir de um golfo onde a formação de crosta oceânica ocorreu, há 816 M.a., no lado brasileiro (?) da bacia.

Os remanescentes da litosfera oceânica do oceano Adamastor - Brasilides são rochas metassedimentares oriundas de sedimentos marinhos profundos, confinadas a este lado. Suítes toleíticas ao longo da Faixa Ribeira possivelmente também registram a conecção entre o Oceano Adamastor - Brasilides e a Faixa Araçuaí.

O modelo evolutivo de Pedrosa Soares para a região envolve o desenvolvimento de um arco magmático relacionado ao consumo de crosta oceânica através de uma zona de subducção mergulhando para leste, no Setor Norte da Faixa Araçuaí. O embasamento da área continental à oeste (em direção ao Cráton do São Francisco) estaria recoberto por rochas supracrustais da Formação Salinas e, à leste, o prisma acrescionário gerado na zona de subdução englobaria parte da s rochas da fácies Ribeirão da Folha. O arco magmático calcio-alcalino localizado mais ao leste gerou grande volume de granitóides calcioalcalinos, sugerindo que uma quantidade razoável de crosta oceânica foi consumida. 
Wernick (1998, 1999) propõe que através do desenvolvimento dos sistemas de cisalhamento que ocorrem na Faixa Ribeira ocorreu o desvio da antiga direção NE/SW, que foi dragueada com o desenvolvimento de grandes estruturas sigmóides, limitadas por falhas E/SW, como os antigos corpos elipsoidais NE/ SW.

Segundo o autor, também os batólitos graníticos foram afetados pelos empurrões NE/SW e falhas de strike-slip. Esta direção EM seria um importante marco temporal que, aliado aos dados de deformaçăo e idades radiométricas, permitiria precisar a idade do Sistema Magmático Pluriserial Ribeira-590. Este Sistema seria composto de vários plutons, lavas e depósitos vulcanoclásticos, gerado entre 615-575 M.a.

Mais tarde (1999) o autor coloca que o trend estrutural do Cinturão Ribeira foi gerado em regime transpressional transcorrente NE/SW afetado por um sistema E/W posterior. Neste sistema, as estruturas associadas aos falhamentos transcorrentes compreenderiam a foliação, plano de dobras e expressivas strike slips geradas e reativadas em regime de stress tensional, transtensional e transcorrente.

Oliveira et al. (1999) realizaram datações isocrônicas $\mathrm{Rb} / \mathrm{Sr}$ em hornblenda gnaisses do embasamento do Cinturão Ribeira, na área de Sapucaia e Conservatória, RJ, Mar de Espanha, MG.

Os resultados obtidos mostraram idades de 2,2 G.a. com $R_{i}$ : 0,7, para a área de Sapucaia e 1,96, Ri: 0,7 para a área de Conservatória, ambas idades com desvios altos, oriundos da remobilização isotópica causada pela deformação dúctil que afetou a região, pois as zonas de cisalhamento presentes possivelmente transportaram o Sr radiogênico.

Brüeckner et al. (2000) em seção transversal E-W, na altura do paralelo $21^{\circ}$, cruzando as Faixas Araçuaí e Ribeira e a porção leste do Cráton do São Francisco (fig.A.5.), dataram em 575 M.a. o metamorfismo granulítico das litologias do Complexo Juiz de Fora, na Faixa Ribeira, obtendo idades $T_{D M}$ 1,6 a 2,0 G.a., concluindo que esta área não foi parte original do Cráton do São Francisco, que apresentou idades de recristalização de $2.1 \mathrm{Ga}$, com idades $\mathrm{T}_{\mathrm{DM}}$ superiores a 2.6 G.a. em rochas no Quadrilátero Ferrífero.

Os autores propõem que a ausência de idades arqueanas na Faixa Ribeira implicaria que esta faixa não é material remobilizado do Cráton do São Francisco, podendo representar um terreno alóctone acrescido no Paleoproterozóico, com partes geradas durante o Ciclo Transamazônico, tendo a Descontinuidade Abre Campo como a zona limite entre a Faixa Ribeira e a Faixa Araçuaí. 

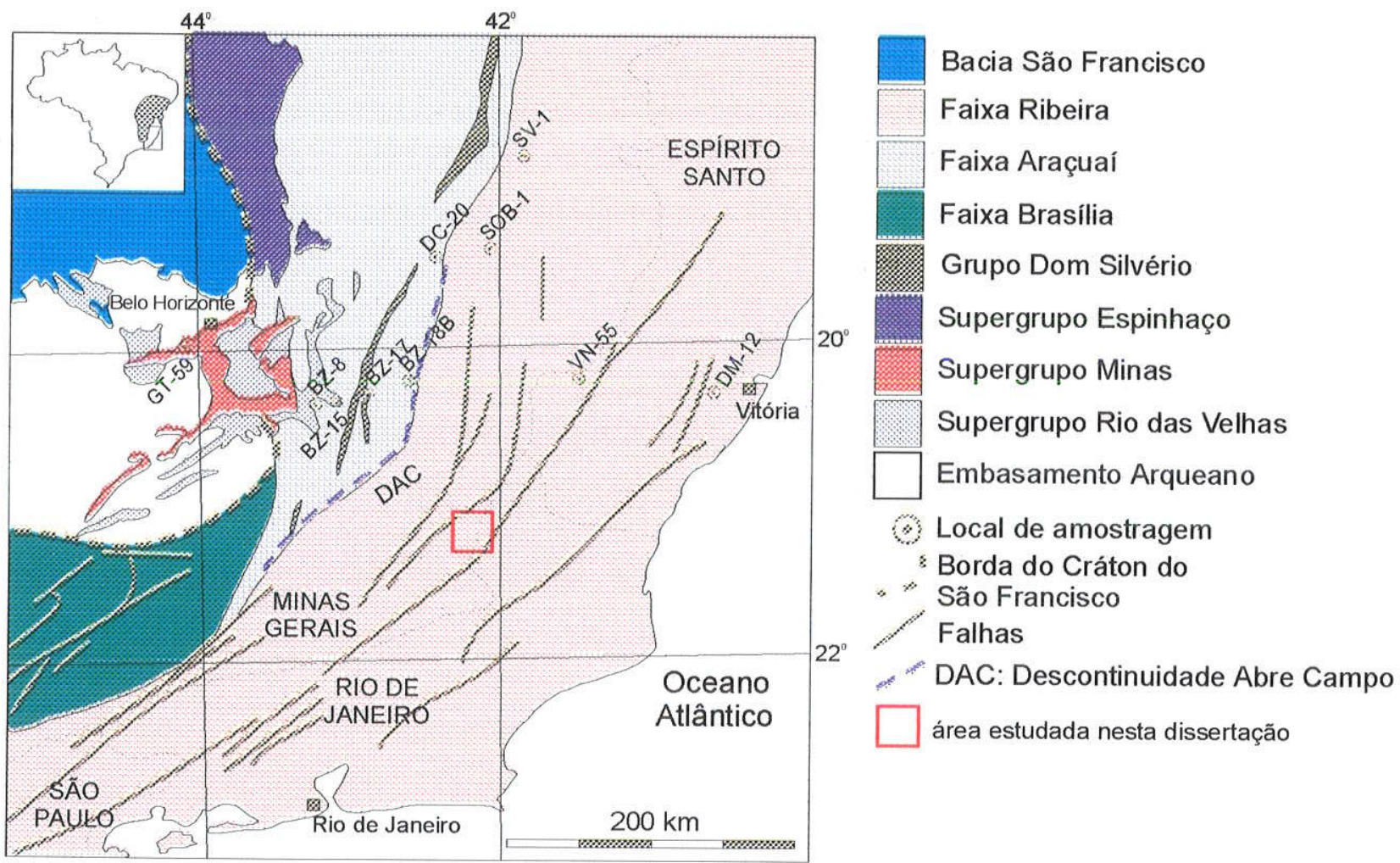

Fig.A.5.: Domínios tectônicos do sudeste segundo Brüeckner et al., 2000.

Machado et al. (2000) obteve idades U/Pb (zircão) de 634 M.a. para granitos précolisionais do Complexo Paraíba do Sul.

Os autores colocaram que a distribuição lateral dos granitos pré-colisionais ao longo do Cinturão Paraíba do Sul é comparável à que ocorre em cinturões orogênicos MesoCenozóicos da América.

O Cinturão Paraíba do Sul possui uma zonação associada à colocação profunda dos granitos, com as associações charnockíticas do Complexo Litorâneo sendo intrudidas sob condições de metamorfismo na fácies anfibolito alto e granulito na parte interna do cinturão.

Os granitos dos Domínios Paraíba do Sul e Serra dos Órgãos, fora da associação charnockítica, foram intrudidos sob condições de metamorfismo de fácies anfibolito na parte externa do cinturão, em direção ao Cráton do São Francisco.

Machado e colaboradores consideraram que a migração lateral do magmatismo sob regime transpressivo pode ser discutida para explicar este zoneamento magmático no espaço orogênico e, diferentes fluidos foram associados a estas diferentes associações graníticas.

Campos Neto \& Caby (2000) detalhou as nappes ao sul do Cráton do São Francisco através de estudos de sua geometria, cinemática e evolução metamórfica, concluindo que 
estas estruturas, constituídas de rochas de alto grau metamórfico, compreeendem duas unidades distintas de rochas na fácies granulito, representando uma seção composta de crosta continental inferior: a Nappe Socorro-Guaxupé (topo, derivada de um terreno de arco magmático) e a Nappe Três Pontas-Varginha (acima, com granulitos localmente retrógrados).

As condições de temperatura e pressão encontradas para a Nappe Três PontasVarginha, com cianita-granulitos preservados, foram de $700-750 \mathrm{Kbar}$. Temperaturas máximas entre $900-950^{\circ} \mathrm{C}$ foram atingidas em direção à base da Nappe SocorroGuaxupé, durante a intrusão de magmas mangeríticos e charnockíticos. Metamorfismo de baixa presão associado à anatexia prevaleceram nos niveis crustais mais superficiais.

Estas nappes granulíticas foram transportadas mais de $200 \mathrm{Km}$ para leste, sobre nappes inferiores, envolvendo embasamento retrabalhado e unidades de margem passiva, ambas metamorfisadas sob alta pressão e baixa temperatura.

O afinamento e resfriamento das duas nappes granulíticas ocorreu antes de sua colocação sobre as nappes superiores.

Campos Neto \& Caby (op. cit.) propuseram um cenário geodinâmico onde a subducção para oeste, sob litosfera oceânica neoproterozóica. As duas unidades granulíticas cristalizaram sob paleogeotermas distintas na zona de subducção à $45 \mathrm{Km}$ de profundidade, há 630 M.a.. Os cianita granulitos foram soerguidos através de extrusão forçada de baixo ângulo, enquanto o colapso sin-colisional afetou o nível crustal mediano do terreno de arco sotoposto. A colocação final das nappes sobre o Cráton do São Francisco e sua cobertura, de anquizona a fácies xistos-verdes, ocorreu há 600 M.a..

Almeida, Brito Neves \& Carneiro (2000) reescreveram o clássico de Almeida (1967) à luz dos conhecimentos geológicos adquiridos ao longo destes últimos 30 anos, produzindo um trabalho abrangente que abordou, tópicos interessantes relacionados à Faixa Ribeira e sua evolução tectônica, num contexto regional. Estes tópicos serão abordados após breve síntese desta publicação.

A Plataforma Sulamericana, definida como porção estável da placa sulamericana em relação às zonas orogênicas fanerozóicas dos Andes e do Caribe, possui embasamento constituído de crostas continentais arqueanas e proterozóicas arranjadas durante três eventos orogênicos principais, no Ciclo Tranzamazônico, durante o Paleoproterozóico; no Mesoproterozóico tardio e durante os Ciclos Panafricano-Brasiliano.

O Ciclo Panafricano- Brasiliano resultou na consolidacão de cinturões móveis neoproterozóicos com o embasamento da plataforma, afetando e configurando o padrão tectônico e estrutural quando a plataforma fazia parte do Gondwana. 
Durante o Fanerozóico foram desenvolvidas seis sequências de cobertura principais. Os estágios finais de individualização da Plataforma Sulamericana e suas sequências pósPaleozóico foram acompanhados de procesos intracratônicos tectônicos e magmáticos (rifteamentos e intrusões alcalinas e basálticas).

Os processos de ativação foram atribuídos à abertura do Atlântico ao leste e à orogenia Andina, à oeste e norte e, uma fração dos eventos de reativação podem ter sido causados por procesos sub-litosféricos de ativação do manto, no interior da plataforma.

A área foco desta dissertação está situada num cinturão móvel neoproterozóico, a Faixa Ribeira.

Almeida et al. (op. cit.) abordaram a origem, classificação e arranjo estrutural dos cinturões brasilianos.

A origem prévia destes cinturões seria relacionada, segundo os autores, à formação de sequências sedimentares e vulcano-sedimentares durante a Tafrogênese Toniana, que originou o supercontinente Rodínia, durante o Mesoproterozóico.

Atividades subsequentes sob regime convergente favoreceram a subducção de áreas oceânicas e a inversão tectônica de sistemas de bacias, rifts continentais, sinéclises e bacias proto-oceânicas de origem na Tafrogênese Toniana.

O estágio final consistiu de movimentos colisionais e transpressionais cuasados pela convergência de blocos neoproterozóicos.

A combinação destes processos desenvolveu um novo ciclo tectônico, o Ciclo Brasiliano, cuja consequência foi a aglutinação do supercontinente do Godwana Ocidental, durante o Neoproterozóico - Cambriano, que manteve apenas alguns fragmentos do supercontinente de Rodínia.

O trend estrutural da Plataforma Sulamericana e sua forma geológica e geográfica, ainda enquanto parte do Gondwana Ocidental, foi controlado por redes de zonas de cisalhamento, que foram seguidas por atividades litogenéticas até o final do Cambriano.

O Lineamento Transbrasiliano divide a Plataforma transversalmente, de NNE para SSW, em dois arranjos distintos de blocos e cinturões neoproterozóicos. Para Oeste, o Bloco Amazônico e suas faixas marginais, e para leste, vários blocos e faixas marginais de diferentes tipos e tamanhos apresentam padrão evolutivo complexo, com evidências de movimentos policíclicos ao longo de zona de cisalhamento continental, desde o Precambriano até o período recente.

Os deslocamentos verticais e direcionais presentes ao longo destas zonas de cisalhamento parecem ocorrer preferencialmente seguindo áreas de deformação prévia, 
de herança tectônica, fato evidenciado pela análise das bacias sedimentares correlatas (como visto em Cordani et al., 1984).

Almeida et al. (op. cit.) concluíram que a Plataforma Sulamericana foi gerada por três colagens complexas durante o Proterozóico, todas seguidas por tafrogênese e dispersão.

A primeira colagem envolveu vários núcleos continentais, durante 0 Paleoproterozóico, com desenvolvimento de cinturões colisionais acrescionários, culminando na formação de uma grande massa continental, há 1.8. G.a.. Esta colagem foi seguida por falhamentos intracratônicos e magmatismo durante a Tafrogênese Estateriana.

A segunda colagem ocorreu durante o Mesoproterozóico tardio, de 1,4 a 0.95 G.a., envolvendo as rochas geradas nos processos tafrogenéticos anteriores e, culminando na formação da massa continental Rodínia.

A fissão neoproterozóica deste supercontinente gerou blocos crustais, bacias continentais e oceânicas, cujo arranjo geométrico definiu os elementos que interagiram para a evolução do Ciclo Brasiliano.

A colagem do Gondwana ocorreu devido às interações entre estes blocos e bacias, ao longo de três fases principais, 750, 600 e 550 M.a. e, o embasamento da Plataforma Sulamericana está localizado no lado ocidental deste supercontinente.

O padrão estrutural estabelecido durante esta colagem, no Ciclo Brasiliano, controlou as feições pré-deriva do continente inteiro. 


\section{A.2. Difratometria de Raios $X$}

Análises de difratometria de raios $X$ foram realizadas para auxílio na determinação da composição mineralógica de várias rochas.

Os difratogramas apresentaram background alto causado pelo efeito da fluorescência secundária Este efeito é consequência da análise feita em tubo de cobre de amostras que apresentam ferro ou manganês.

Os procedimentos referentes a estas análises estão descritos no cap. 2.1. e os difratogramas estão descritos e ilustrados a seguir.

Fig. A.6. KJ 378 e Fig.A.7. KJ 3782b - biotita-granada gnaisse granulítico de coloração cinzenta e finamente bandado, pertencente ao Complexo Juiz de Fora (jfkz), de composição estimada charnoenderbítica com granulação fina a média. A composição mineralógica consta de plagioclásio, quartzo, feldspato alcalino, ortopiroxênio, biotita, granada, minerais opacos, zircão, apatita, monazita e titanita. As raias do ortopiroxênio ocorrem encobertas pelas raias do microclínio. Magnetita e goethita foram identificados na petrografia mas suas raias não foram identificadas nos difratogramas, provavelmente por constituirem menos de $2 \%$ da rocha. 


\section{KJ378}

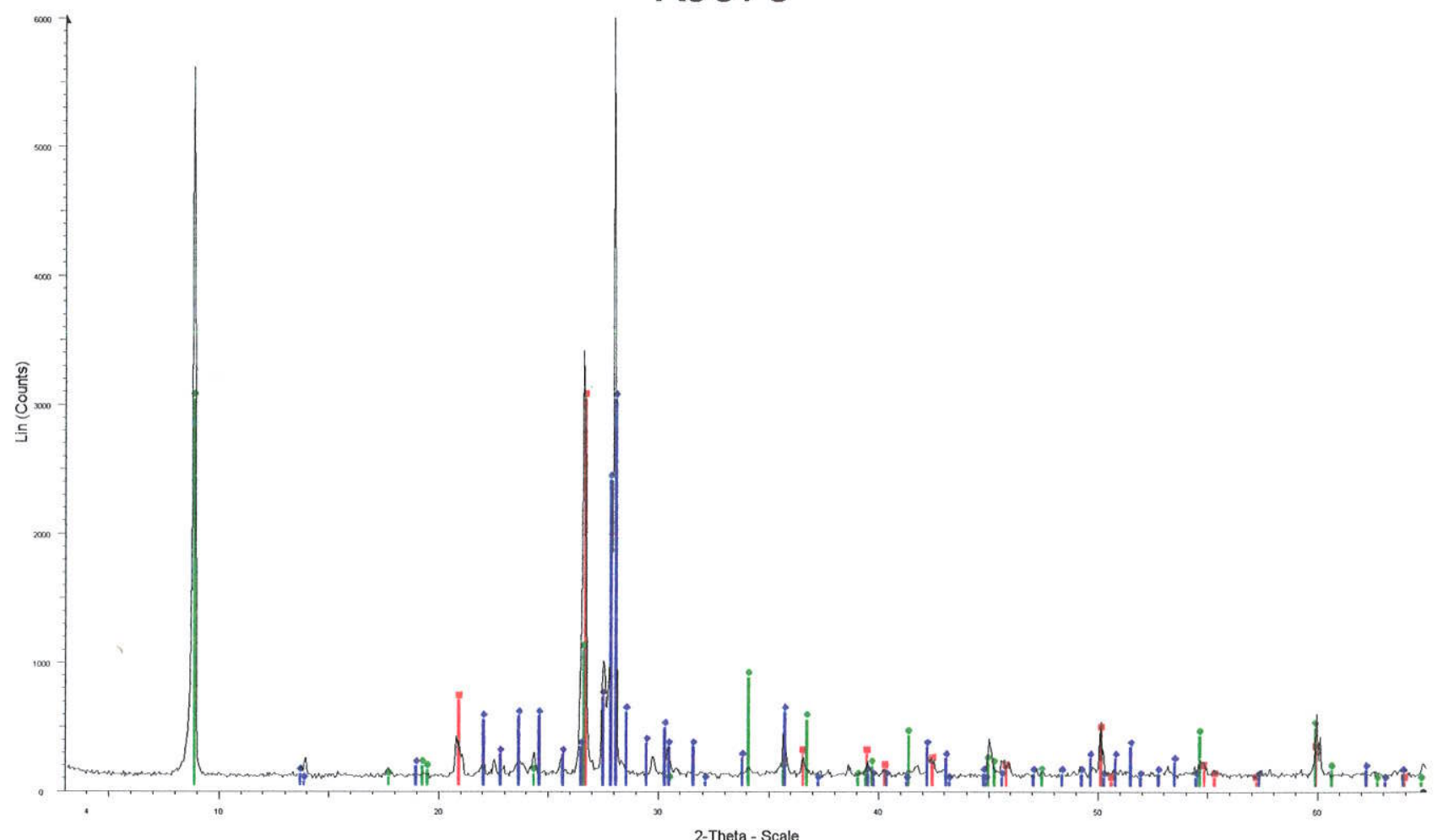

2-Theta - Scale

Wc:Idatalmarcostthanialkj378.RAW - File: kj378.RAW - Type: 2 Th/Th locked - Start: $3.000^{\circ}$ - End: $65.000^{\circ}$ - Step: $0.050^{\circ}$ - Step time: $1.0 \mathrm{~s}$ - Temp.: $27.0^{\circ} \mathrm{C}$ - Time Started: $27 \mathrm{~s}-2$-Theta: $3.000^{\circ}$ - Theta Operations: Import

33-1161 (*) - Quartz, syn - SiO2 - Y: $50.00 \%$ - d x by: 1.000 - WL: 1.5405

- 42-1437 (I) - Biotite-1M - K(Mg.Fe+2)3(Al,Fe+3)Si3O10(OH,F)2 - Y:50.00\% - d x by: 1.000 - WL: 1.54056

42-1437 (I) - Biotte-1M - K(Mg, Fe+2)3(A,,Fe+3)Si3O10(OH,F)2 - Y: $50.00 \%$ - $\mathrm{d} x$ by: 1.000 - WL: 1.54056

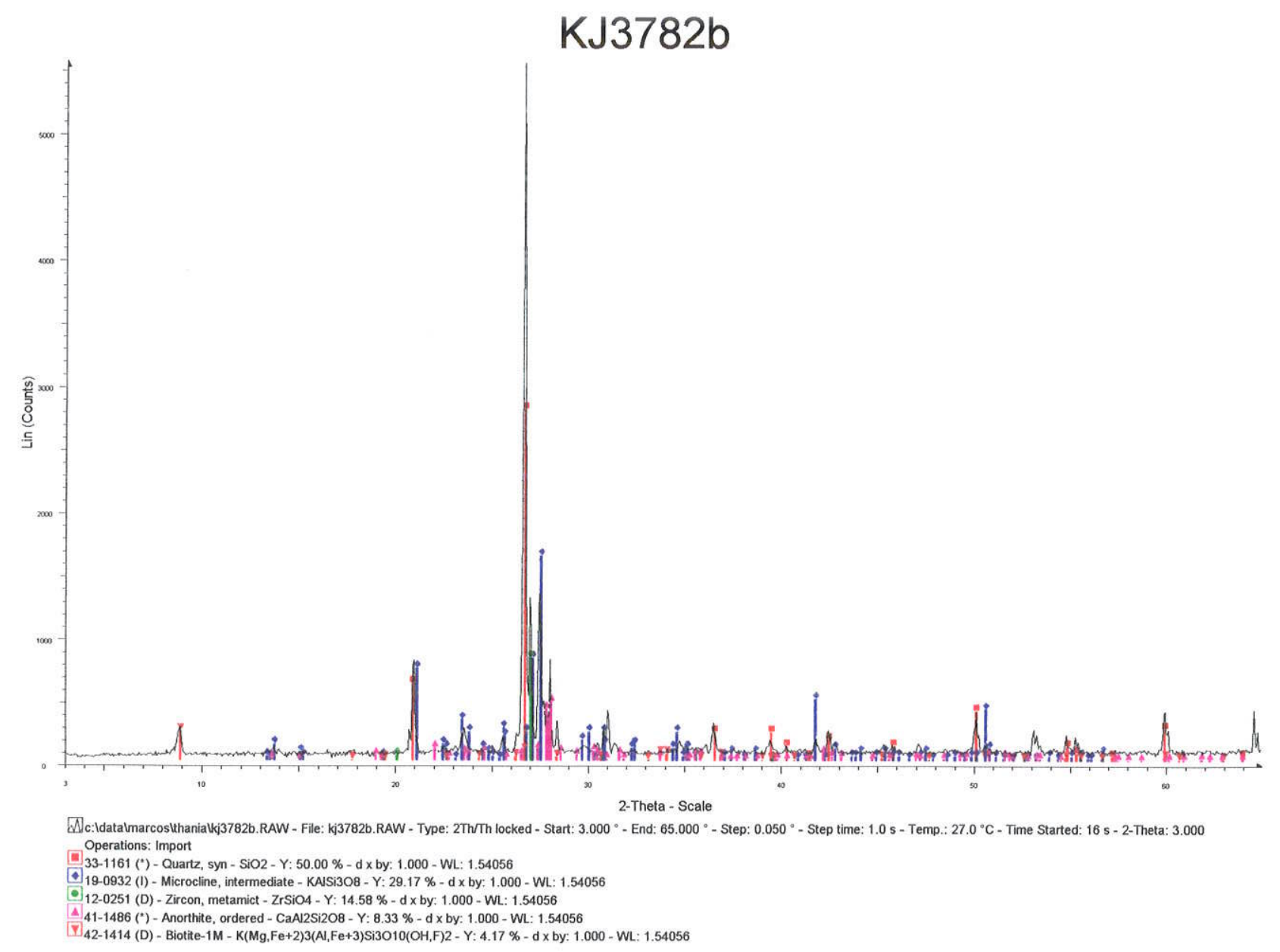


Fig. A.8. KJ 379 -biotita-granada gnaisse granulítico de coloração cinzenta e bandamento fino que ocorre em contato com granulito, ambos do Complexo Juiz de Fora (respec. jfkz, jfgg). Composição mineralógica como a das amostras anteriores, com a ocorrência também de clinopiroxênio, que foi identificado no microscópio de luz transmitida como diopsídio. Nesta amostra, as raias do microclínio foram desativadas pelo programa gerenciador de dados para visualização da raia principal do piroxênio. Note o elevado conteúdo em ferro da amostra, que causou o alto background visto no difratograma.

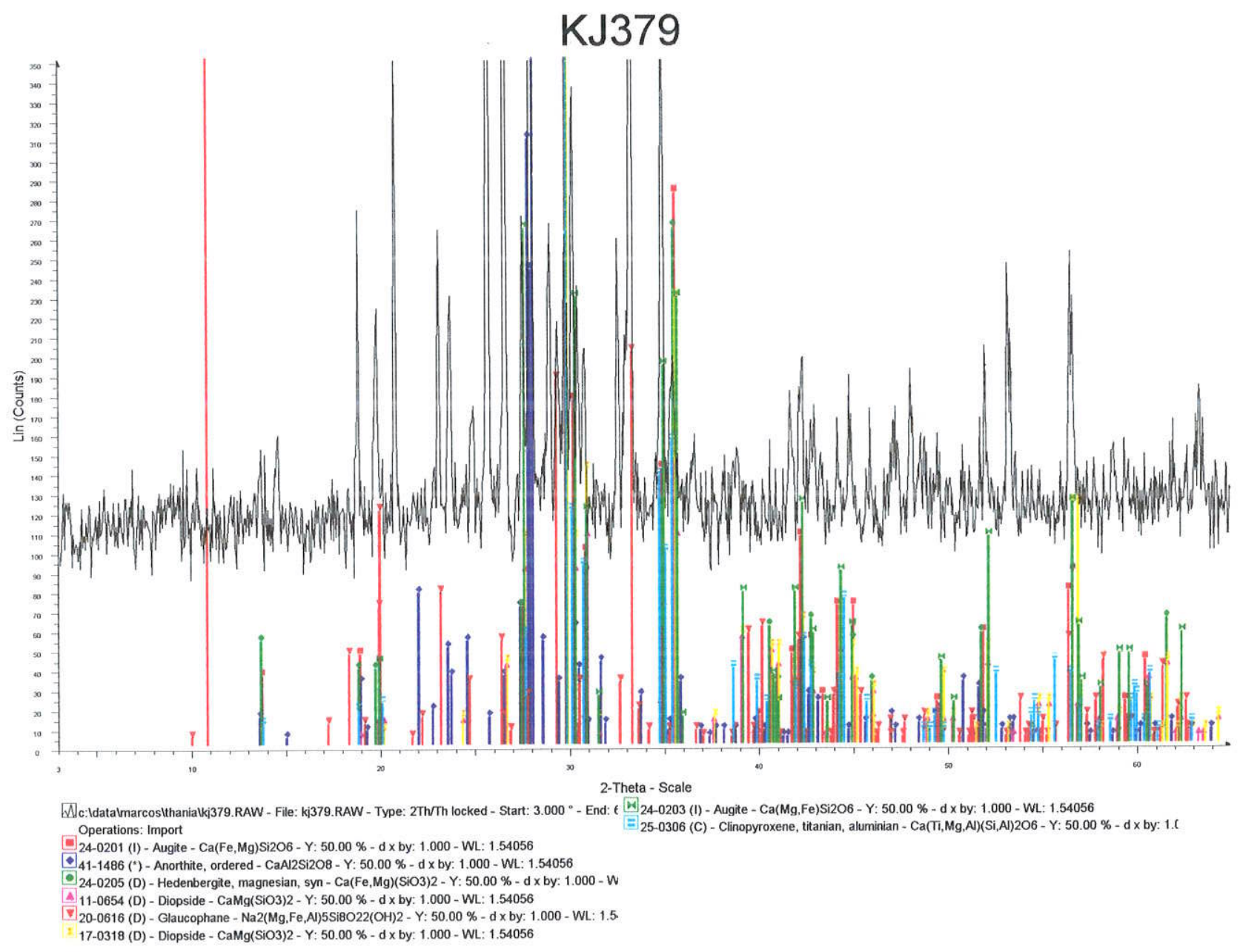


Fig. A.9. KJ3831 -biotita-granada gnaisse granulítico fortemente deformado que ocorre em contato com charnockito (KJ3834c), ambos do Complexo Juiz de Fora (respec. jfkz, jfgg).

Composição mineralógica similar à dos granada-gnaisses granulíticos anteriores, e apresentou carbonato. A magnetita foi identificada em seção polida, mas suas raias estão ausentes do difratograma, pois o mineral ocorre em teores abaixo do limite de detecção do método.

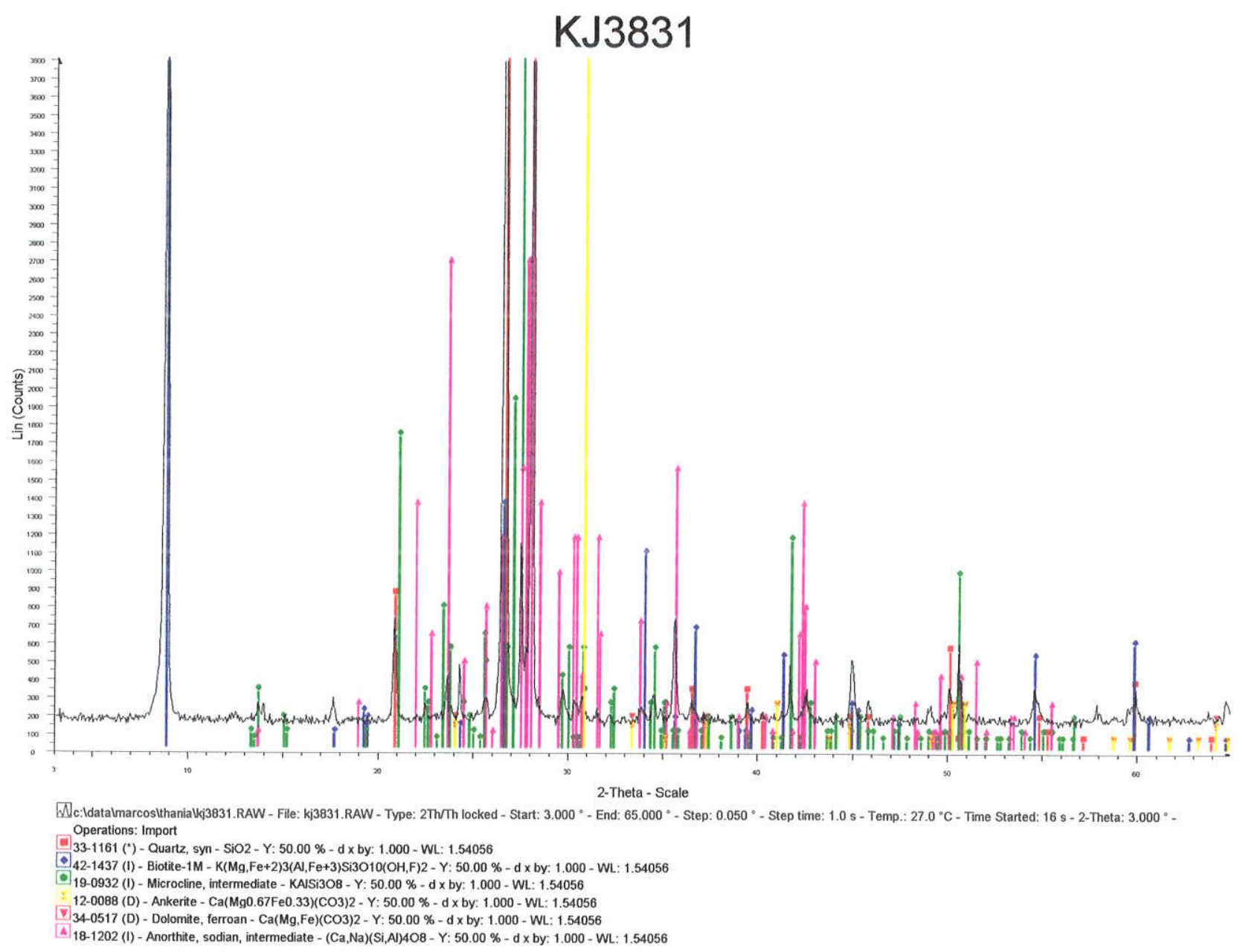


Fig. A.10. KJ3834c - charnockito citado em contato com KJ3831, de aspecto homogêneo e coloração escura, granulação grossa, pertencente ao Complexo Juiz de Fora (jfgg).

Na petrografia foram identificados ortopiroxênio e clunopiroxênio e a raia principal do diopsídeo está visível no difratograma. A raia principal do anfibólio está visível e este mineral foi identificado em seção delgada como hornblenda. A cordierita não foi identificada em seção delgada, mas sua raia principal ocorre no difratograma.

\section{KJ3834C}

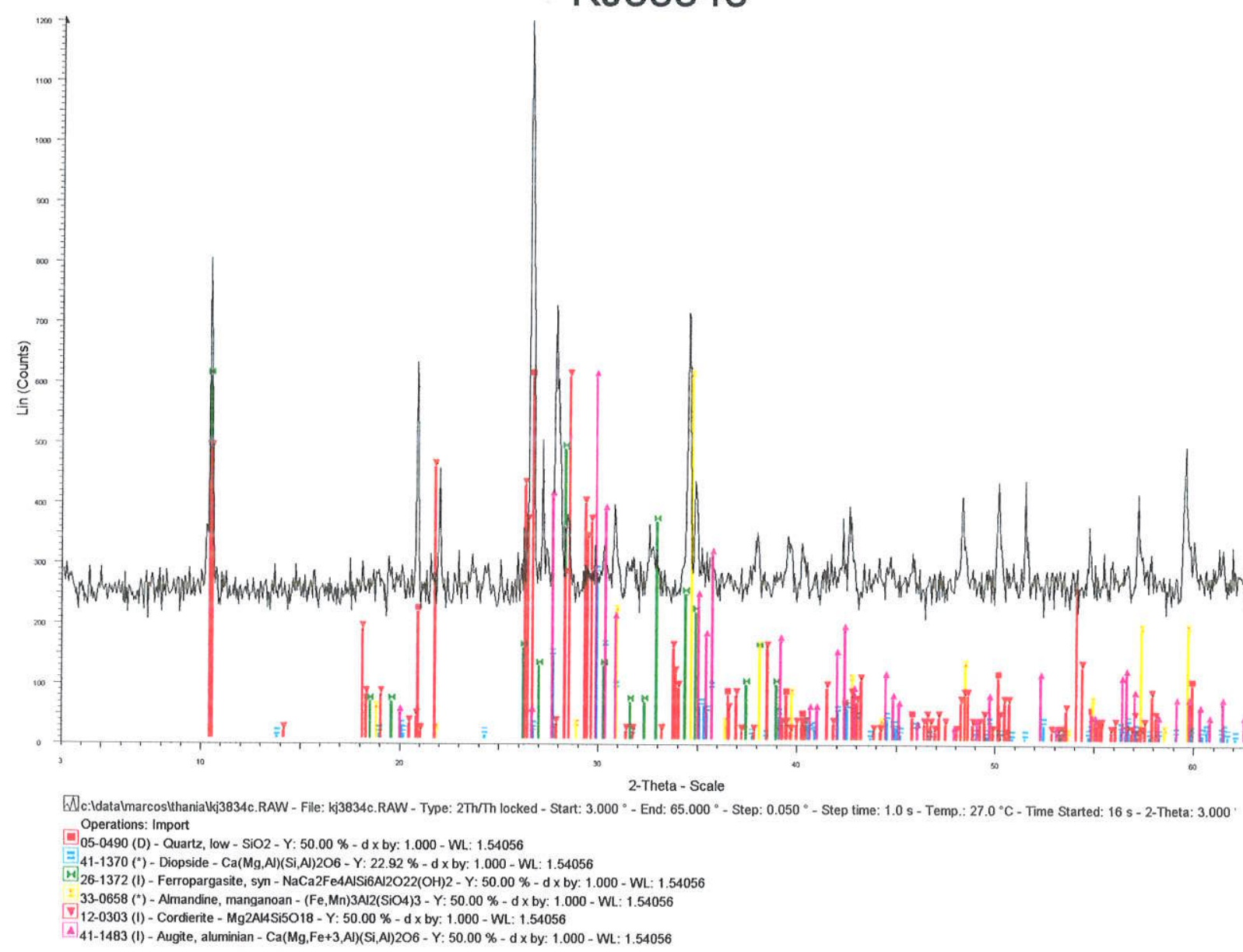


Fig. A.11. KJ3841e - granada granulito de coloração escura, granulação fina e finamente foliado, com granada no plano da foliação granulítica. Ocorre em contato com gnaisse granulítico de bandamento fino, ambos pertencentes ao Complexo Juiz de Fora (jfgg).

A composição mineralógica mostra efeitos de retrometamorfismo, pois ocorre substituição do piroxênio por hornblenda, e a raia principal do anfibólio está visível no difratograma. Minerais opacos secundários foram identificados ao microscópio mas não mostram raias visíveis no difratograma.

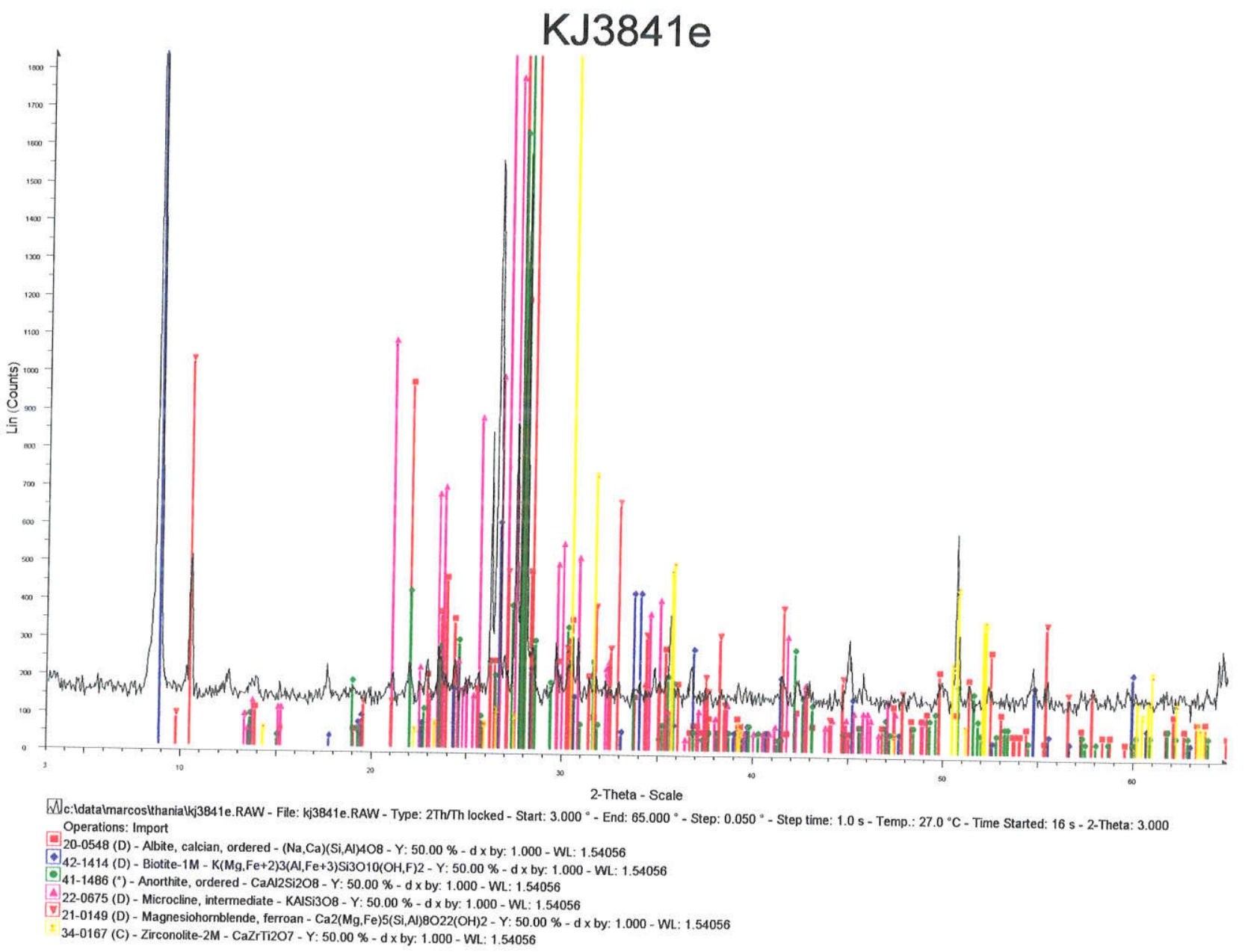


Fig. A.12. KJ3852 -biotita-granada gnaisse granulítico (KJ3852) com boudin de anfibolito, ambos pertencentes ao Complexo Juiz de Fora (jfkg). O gnaisse tem composição mineralógica similar a das rochas granulíticas já descritas. As raias do ortopiroxênio estão encobertas pela raias do microclínio. Presença de ferro na amostra.

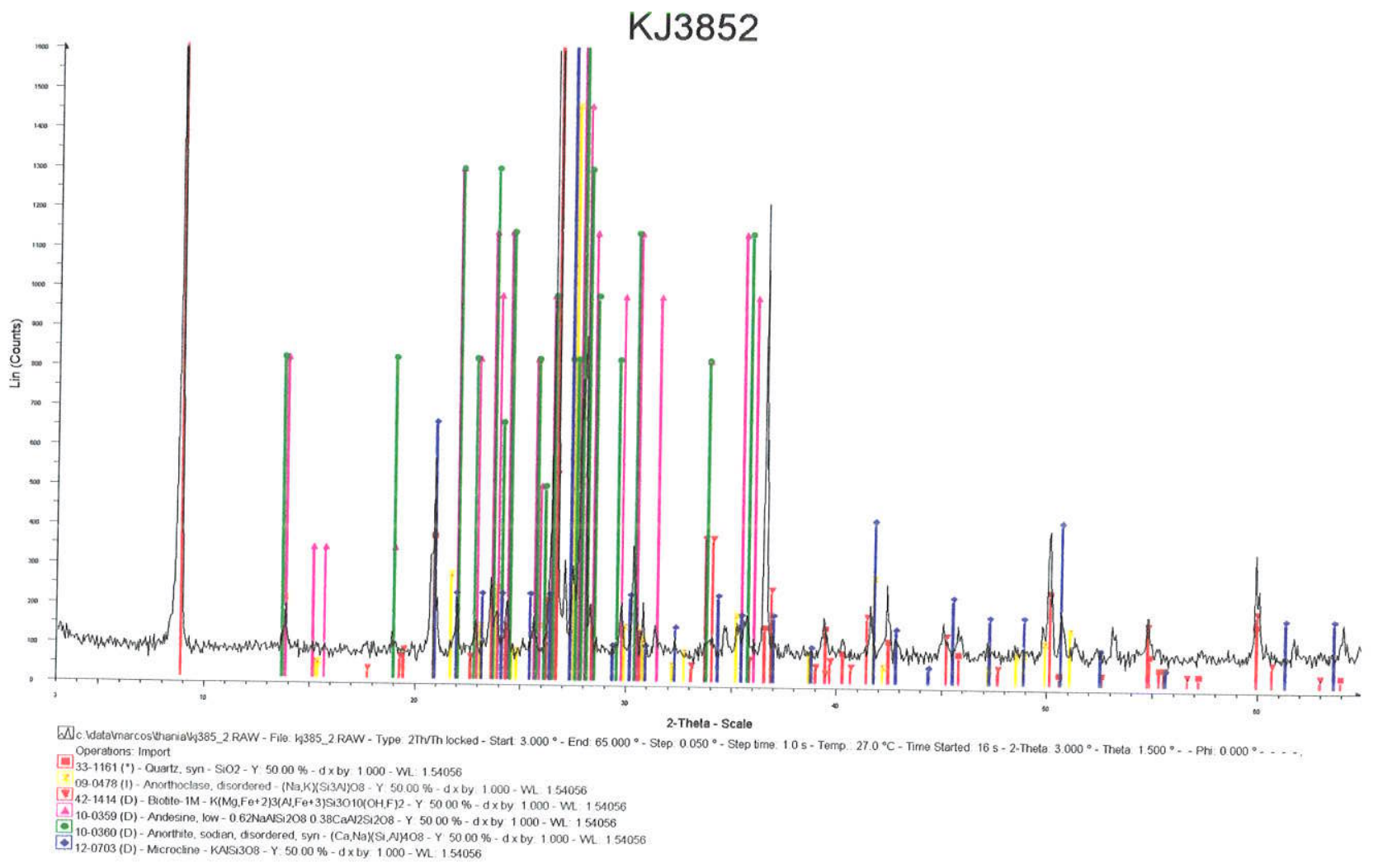


Fig. A.13. KJ3853dx - lente de anfibolito que ocorre na rocha supra citada. A rocha é composta basicamente de hornblenda e plagioclásio. As raias da hornblenda são visíveis no difratograma.

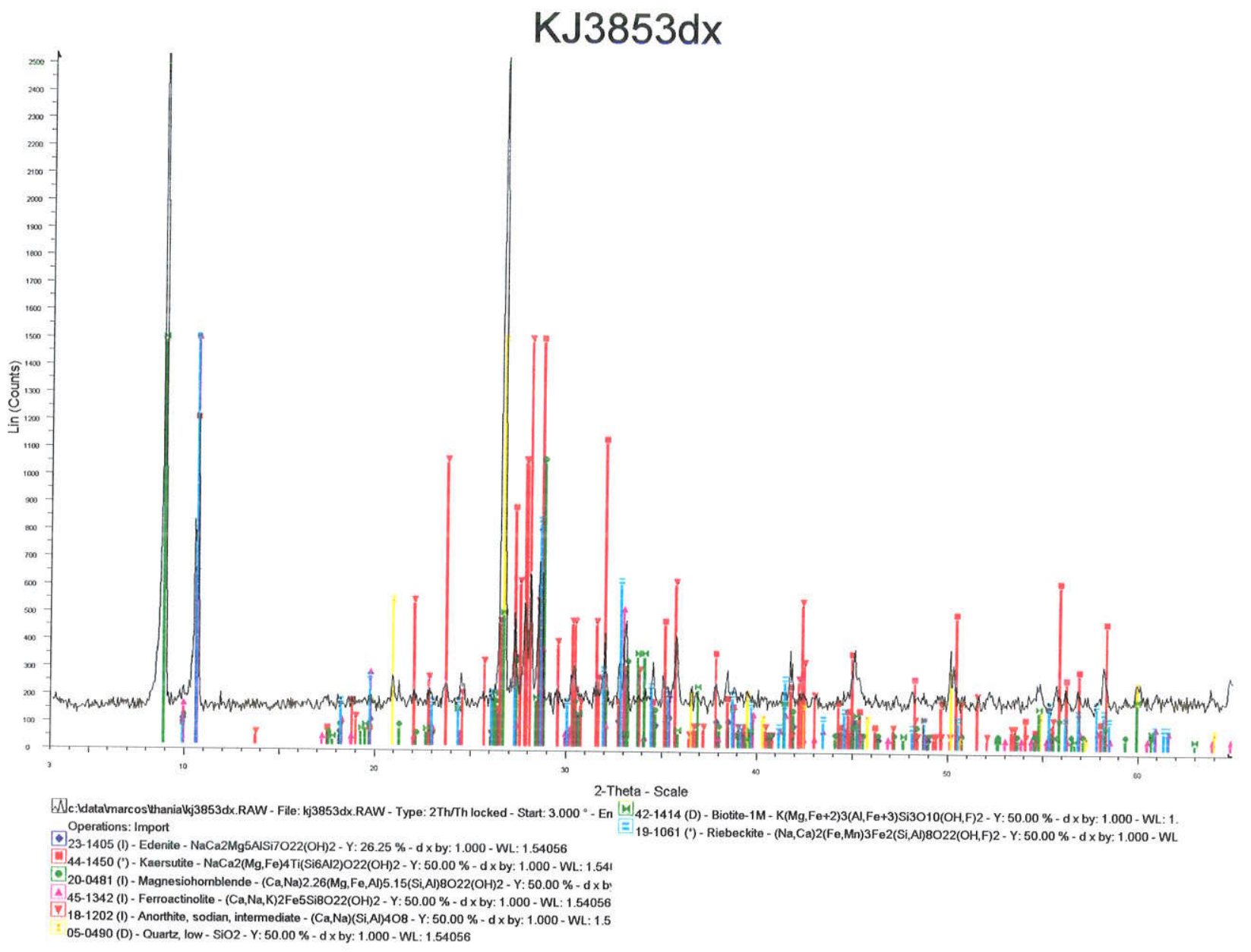


Fig. A.14. KJ3872d -granada granulito finamente foliado pertencente ao Complexo Juiz de Fora (jfgg), com características gerais similares aos granulitos já citados.

As raias que representam a série da columbita-tantalita estão presentes no difratograma, embora os minerais desta série não tenham sido identificados em lâmina delgada.

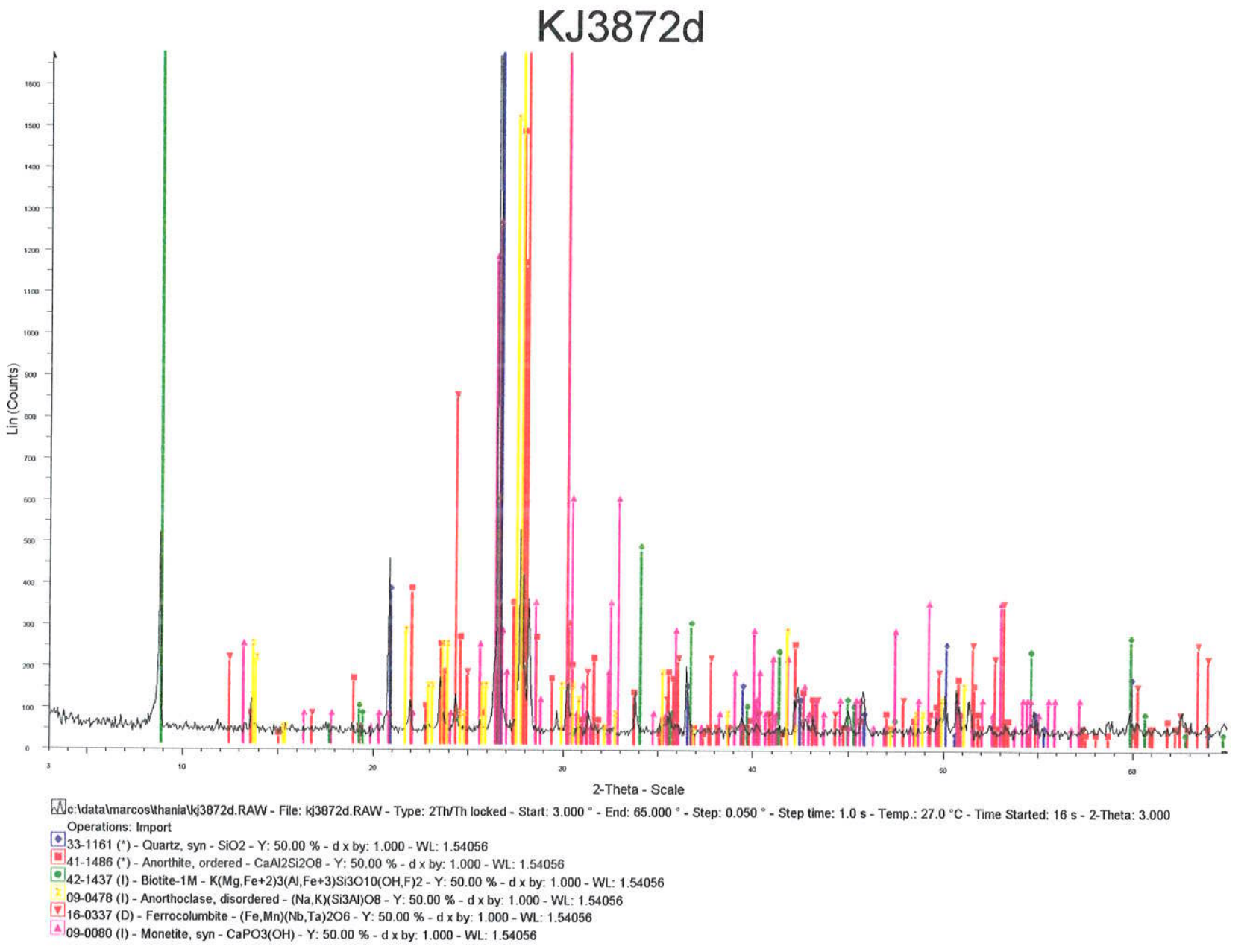


Fig. A.15. KJ388 - granada-biotita gnaisse milonítico, fortemente foliado, pertencente ao Complexo Paraíba do Sul.

As raias visíveis do anfibólio corroboram com a identificação da hornblenda em lâmina delgada.

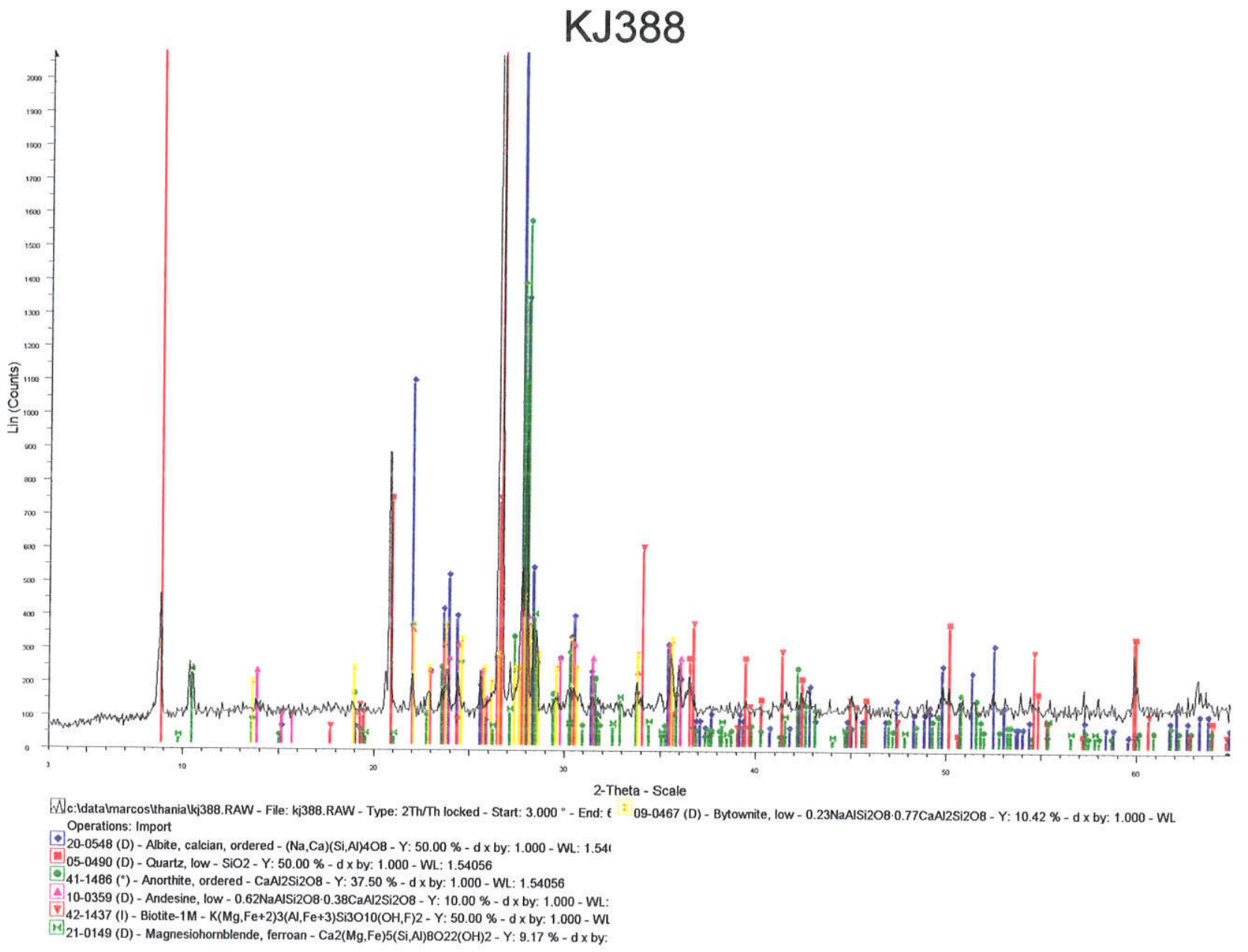


Fig. A.16. KJ3892c - granada-hornblenda-biotita-sillimanita gnaisse migmatizado pertencente ao Complexo Paraíba do Sul (pskz), que apresenta xenólitos de granulito máfico.

As raias da calcossiderita estão visíveis no difratograma e corroboram com a ocorrência de sulfetos (secundários) nesta rocha e em outras deste complexo, onde foram identificados em seção polida também bornita, pirrotita e calcopirita.

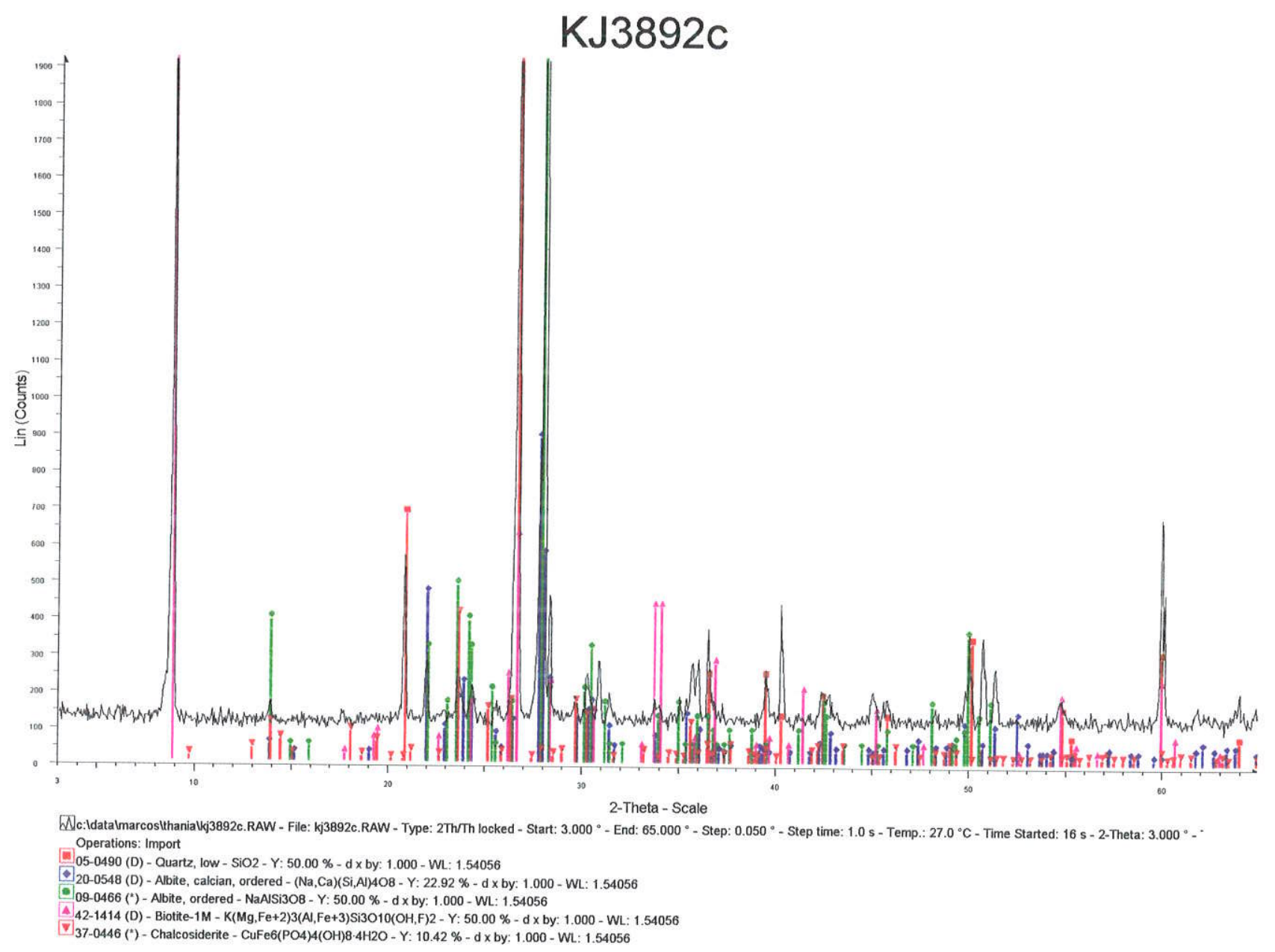


Fig. A.17. KJ3902 - gnaisse granulítico com granada, fortemente migmatizado e hidrotermalizado, pertencente ao Complexo juiz de Fora (jfgg).

O piroxênio tem suas raias encobertas pelas raias do microclínio, que representa o grupo dos feldspatos no difratograma. Embora não identificada petrograficamente, através do difratograma foi identificada a presença de cordierita e carbonato.

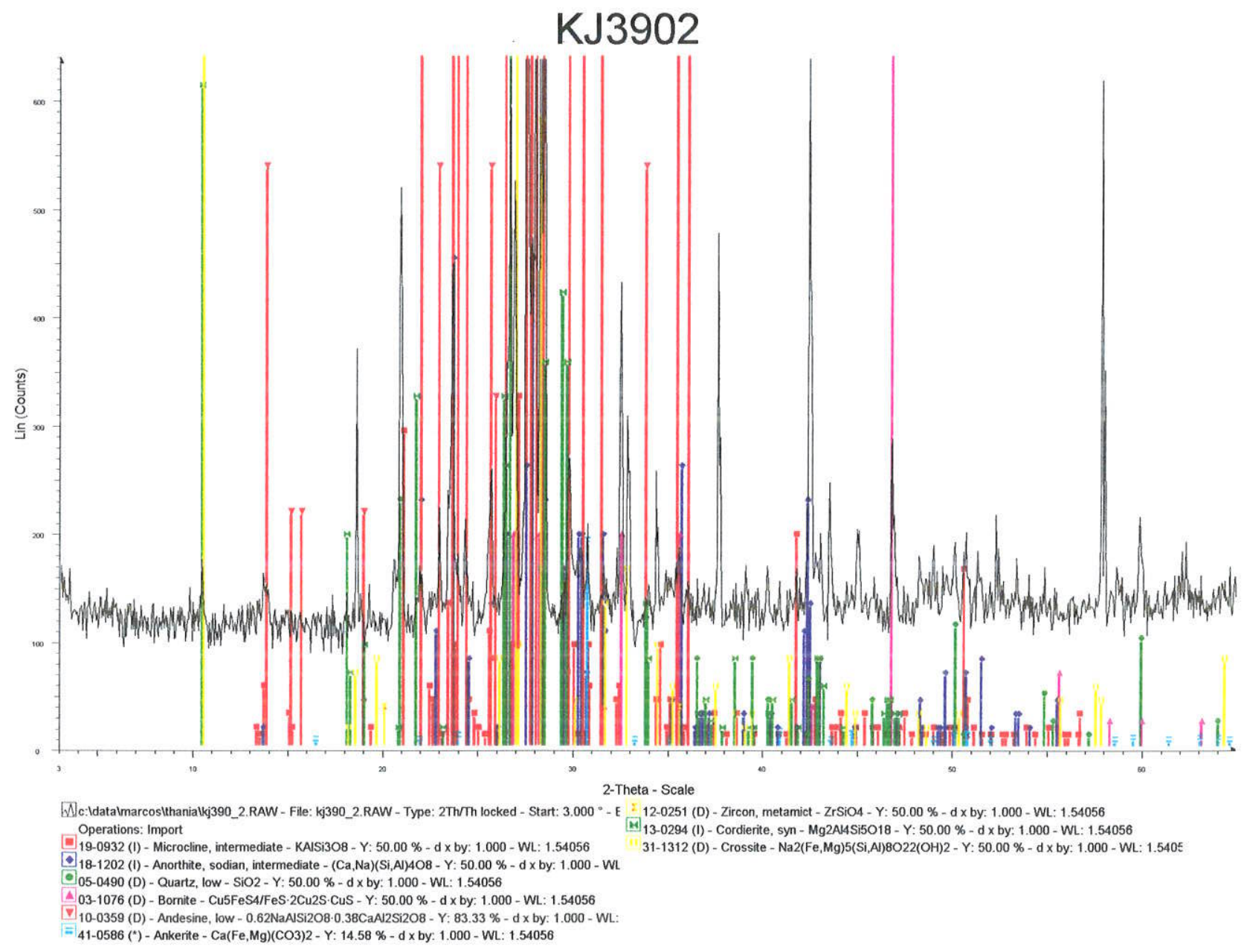


Fig. A.18. KJ418 - biotita-hornblenda gnaisse, fortemente recristalizado e bandado, pertencente ao Complexo Paraíba do Sul (pskg). Apresenta xenólito de gnaisse granulítico.

Composição mineralógica contituída de microclínio, quartzo, plagioclásio, biotita, hornblenda e minerais opacos. Foi feita busca pelas raias da magnetita, ilmenita, calcopirita e bornita, que foram identificadas em seção polida, mas estas raias não são visíveis no difratograma, provavelmente porquê estes minerais apresentam concentrações inferiores a $2 \%$ na rocha, ocorrendo em teores inferiores aos detectáveis pelo método.

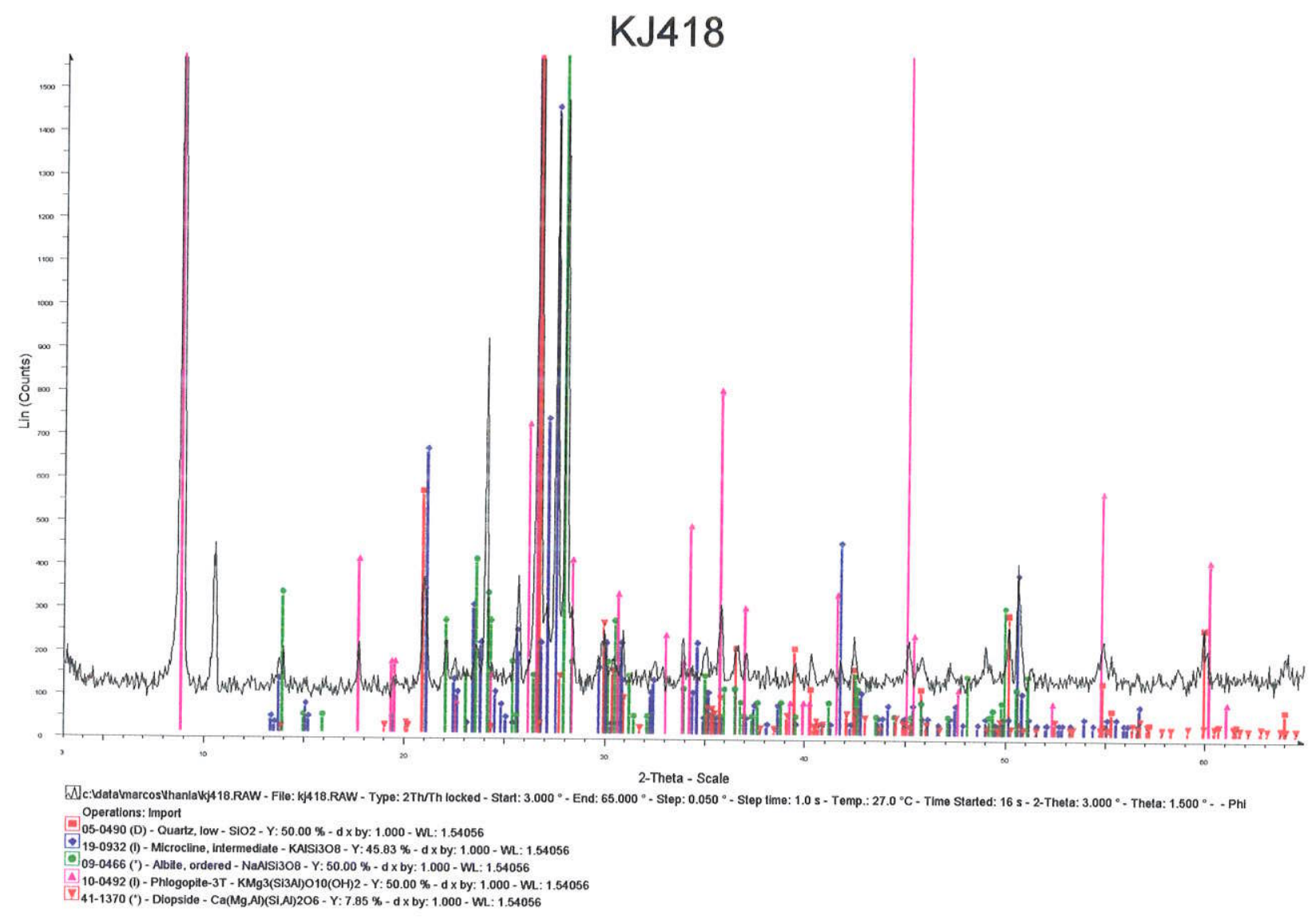


Fig. A.19. KJ425 - biotita granada gnaisse granulítico milonitizado e finamente bandado, com lentes de anfibolito finas e pequenos xenólitos máficos. Pertencente ao Complexo Juiz de Fora (jfkz).

Este gnaisse é composto de quartzo, plagioclásio, biotita, granada, sillimanita, epidoto, zircão e apatita e minerais opacos: magnetita e hematita.

As raias identificáveis são de quartzo, feldspatos e biotita. A sillimanita, apesar de identificada em seção delgada, não está visível no difratograma.

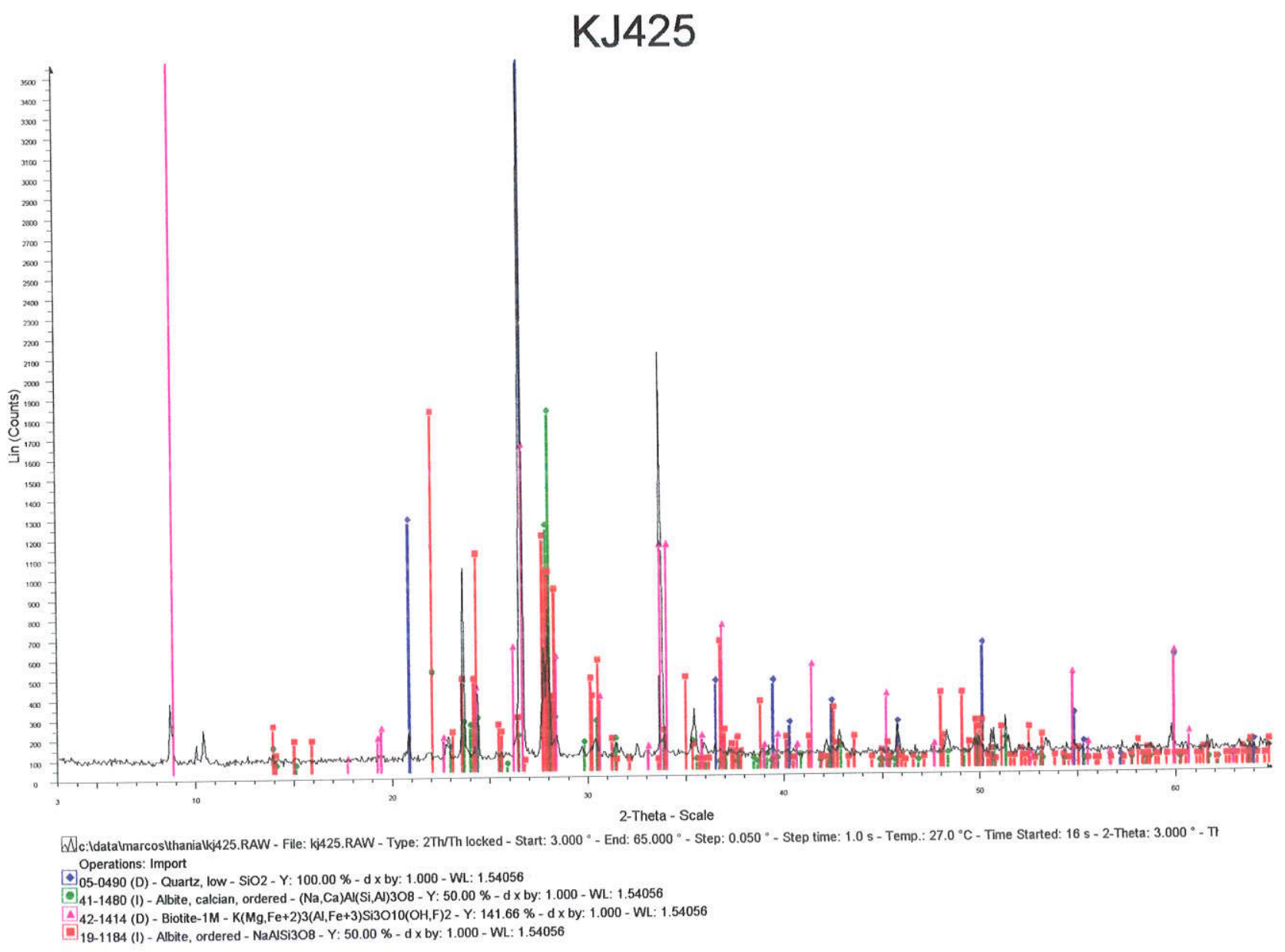


Fig. A.20. KJ431 - gnaisse granulítico retrometamorfizado de granulação fina e pertencente ao Complexo Juiz de Fora (jfgg). Está em contato com um granito, e ambos apresentam sinais de alteração hidrotermal, com óxidos secundários disseminados nas rochas, mas sem raias visíveis destes minerais.

O gnaisse granulítico apresenta orto- e clinopiroxênio que foi identificado em seção delgada como diopsídeo e cuja raia é visível no difratograma. A composição mineralógica fundamental da rocha é similar a dos gnaisses granulíticos anteriormente descritos deste grupo.

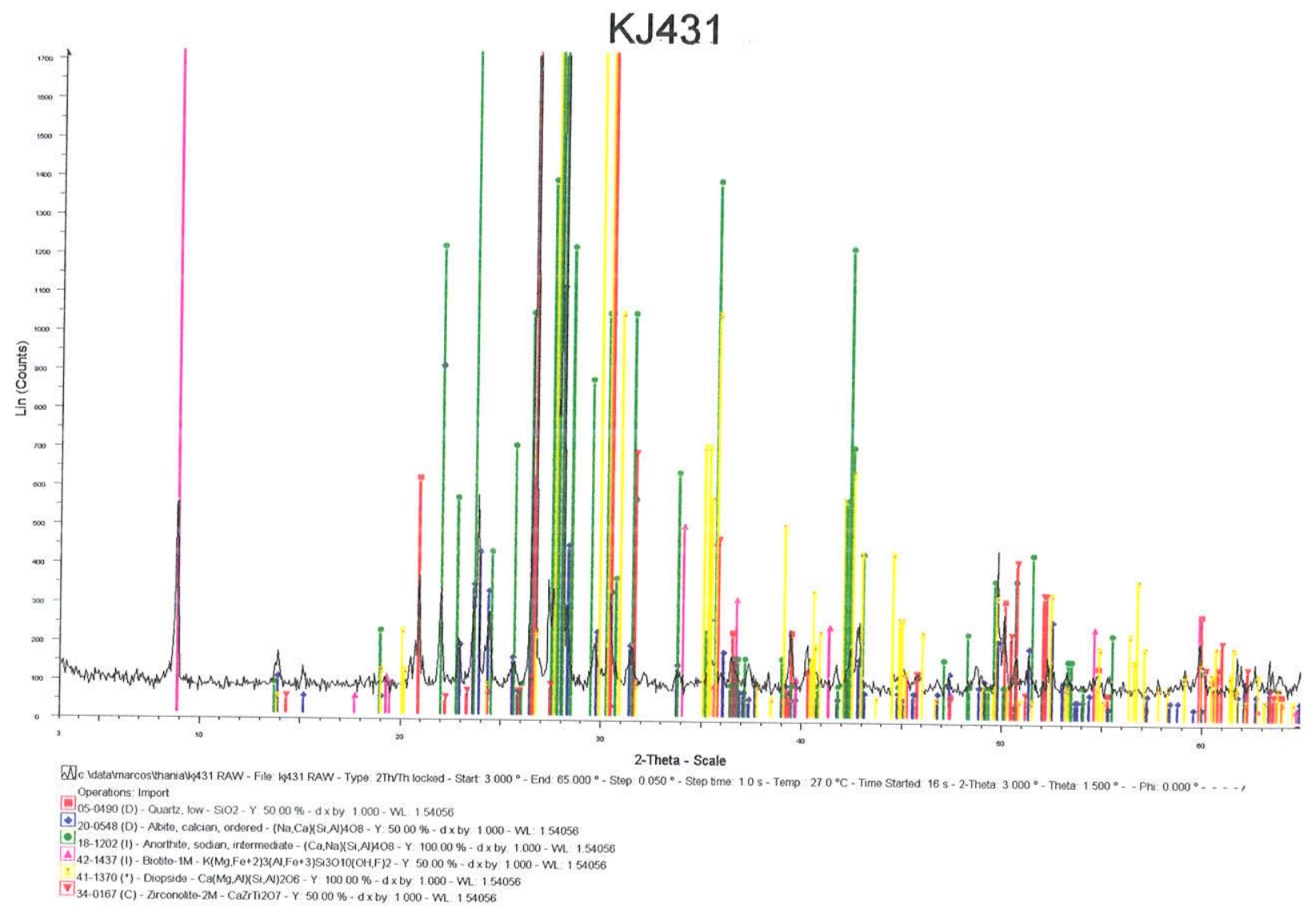


Fig. A.21. KJ442 - granulito máfico do Complexo Juiz de Fora (jfgg), maciço e homogêneo. Composição mineralógica contituída de quartzo, plagioclásio e biotita, com traços de hornblenda. O anfibólio substitui o piroxênio e ocorre associado a biotita, visível em lâmina delgada e as raias do anfibólio são visíveis no difratograma.

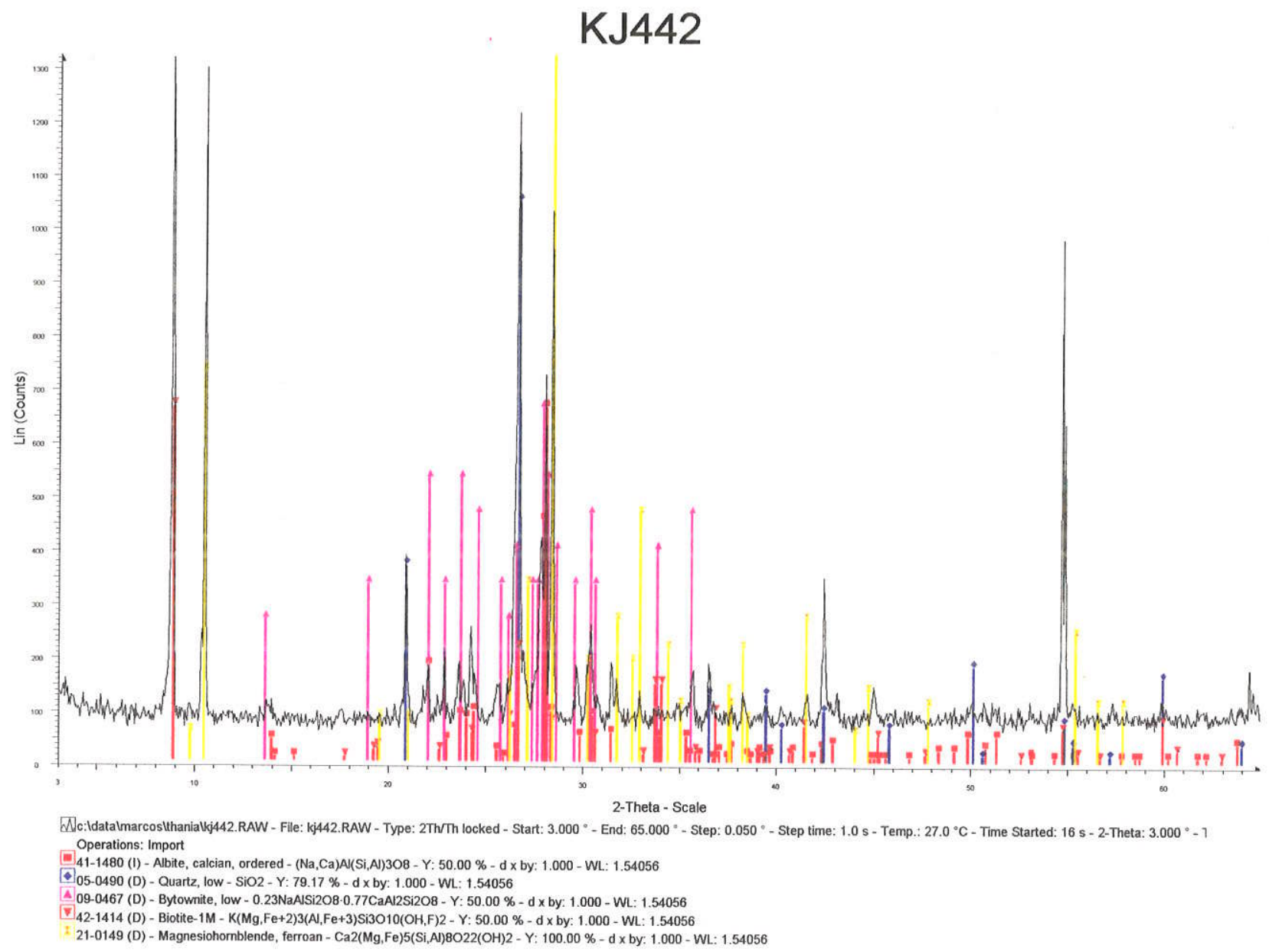




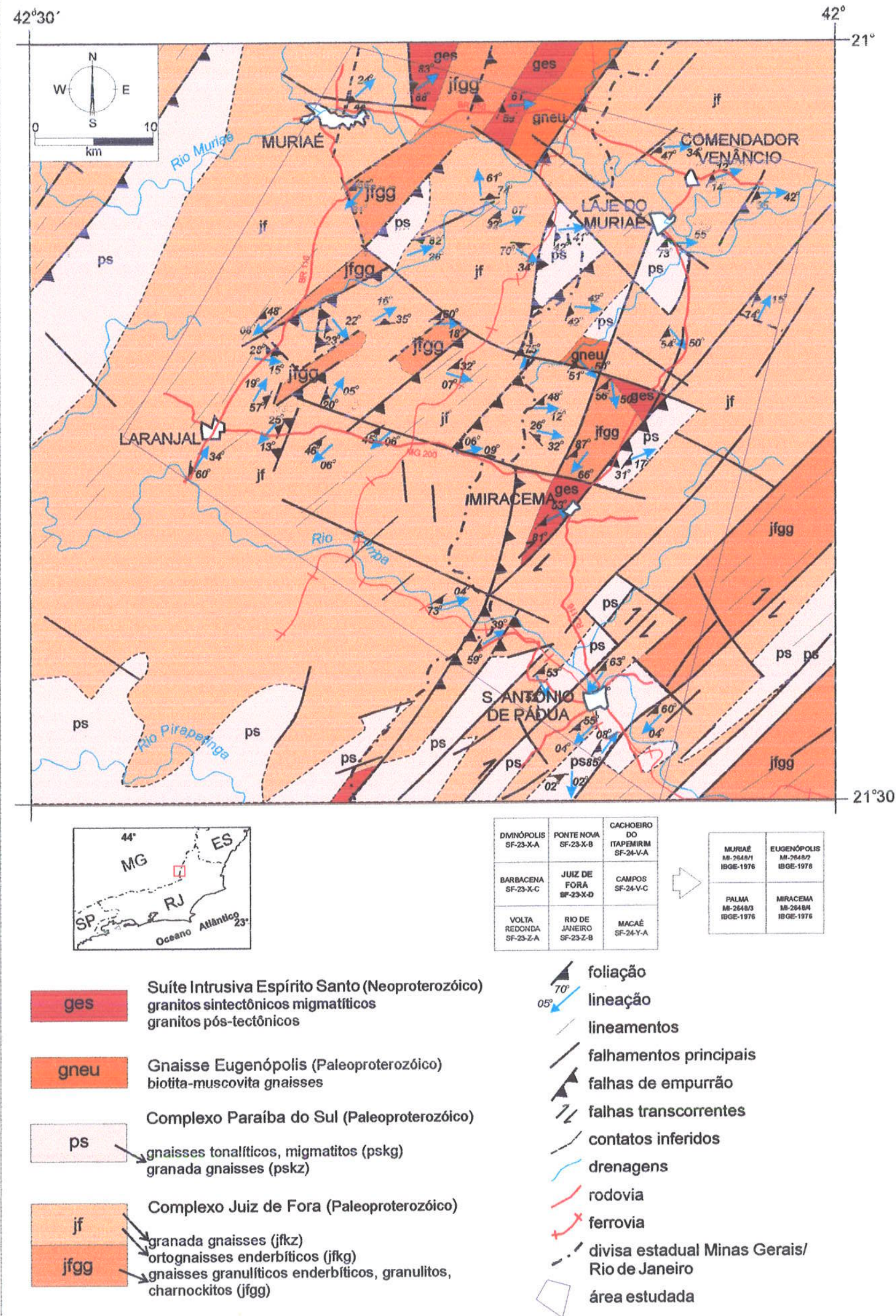

